\title{
COMPORTAMIENTO SUICIDA
}

Reflexiones críticas para su estudio desde un sistema psicológico

Mauricio Ortega González

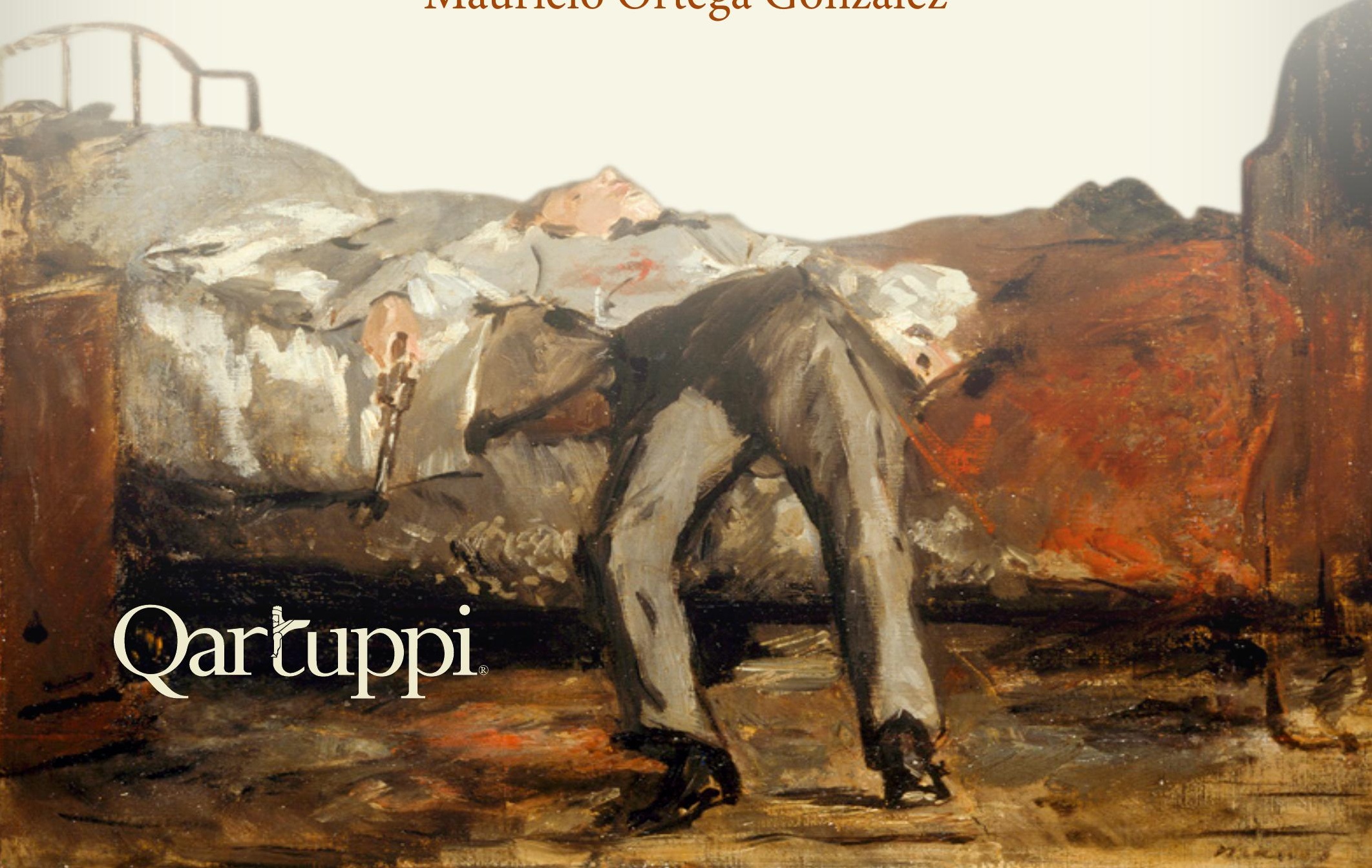




\section{(c) $(1) \circledast$}

Esta obra está bajo una Licencia Creative Commons

Atribución-NoComercial 4.0 Internacional.

https://creativecommons.org/licenses/by-nc/4.0/deed.es

\section{CLÁUSULA DE EXENCIÓN DE RESPONSABILIDAD}

Los puntos de vista, opiniones y posiciones expresadas en esta obra son responsabilidad del autor y/o proveedores de contenido; y no necesariamente reflejan o coinciden con aquellas de índole institucional, donde el autor pudiera prestar sus servicios profesionales.

A su vez, Qartuppi, S. de R.L. de C.V. renuncia a la responsabilidad que pudiera llevar la certeza, validez, utilidad, integridad, impacto, implicaciones o derivaciones legales que cualquier parte del contenido aquí publicado tenga o pueda llegar a tener en cualquier momento. A su vez, no se asume responsabilidad alguna en relación con la información aquí expresada; ni de las pérdidas, problemas, daños o perjuicios derivados por su uso o reproducción posterior. 


\section{COMPORTAMIENTO SUICIDA}

Reflexiones críticas para su estudio desde un sistema psicológico

Mauricio Ortega González

Qartuppi 
Obra dictaminada por:

Dr. Juan José Irigoyen Morales

UNIVERSIDAD DE SONORA

Dr. Aldo Bazán Ramírez

UNIVERSIDAD AUTÓNOMA DEL ESTADO DE MORELOS

\section{COMPORTAMIENTO SUICIDA}

Reflexiones críticas para su estudio desde un sistema psicológico

1era. edición, mayo 2018

ISBN 978-607-97784-8-4

DOI 10.29410/QTP.18.05

D.R. @ 2018. Qartuppi, S. de R.L. de C.V.

Villa Turca 17, Col. Villas del Mediterráneo

Hermosillo, Sonora 83220 México

http://www.qartuppi.com

Edición: Qartuppi, S. de R.L. de C.V.

Portada: "Le Suicidé” (detalle) (ca. 1877) por Édouard Manet (1832-1883) 


\section{A Bárbara Guadalupe Ortega Zuñiga, por cambiar mi vida para siempre con sus cuarenta y dos cualidades que le dan sentido a la vida, el universo y todo lo demás. \\ A ella, a quien quiero tanto como a nadie por infinitas razones, mi más sincero y profundo afecto, respeto y admiración. Gracias por todo.}


Todas las cosas buenas son poderosos estimulantes en favor de la vida, incluso un buen libro escrito contra la vida.

F. Nietzsche 


\section{ÍNDICE}

Prefacio

\section{INTRODUCCIÓN}

CAPít Ulo 1. Antecedentes históricos y filosóficos del suicidio

Período de la Antigua Grecia

Perídodo de la Edad Media

Periodo Moderno

El suicidio en el siglo XXI

Conclusiones

CAPít ulo 2. Teorías e investigaciones sobre el suicidio en la psicología contemporánea

Estado actual de la psicología

Teorías psicológicas del suicidio

Limitaciones de las teorías psicológicas del suicidio

Perspectiva organocéntrica del suicidio

La anormalidad del comportamiento suicida: ¿condición o atribución?

Intencionalidad

Conciencia

69

Libertad

71

Conclusiones 
Antecedente aclaratorio

Acerca de la ciencia

Conductismo radical de Skinner: la ciencia en psicología

\section{CAPÍt ulo 5. Tecnología interconductual aplicada al comportamiento suicida}

¿Qué es la tecnología?

$$
\text { Estado actual de la tecnología psicológica en el suicidio }
$$

¿Qué sabemos del comportamiento suicida?

Prevención del suicidio

$$
\text { Consideraciones de la tecnología psicológica en el suicidio }
$$

Análisis Contingencial: tecnología psicológica para el control del suicidio

Directrices para la construcción de un programa tecnológico del comportamiento suicida

\section{CAPÍt Ulo 6. Reflexiones en torno al control del suicidio}

La generación de conocimiento mediante el control del suicidio

Control del suicidio y violencia

Control del suicidio como instrumento de justicia y el ámbito jurídico

El bien moral y la responsabilidad en el suicidio

Vida, muerte y suicidio 


\section{PREFACIO}

Debo iniciar confesando que considero el tema del suicidio como uno de los más complejos y delicados de abordar, pero a la vez como uno de los más bellos e interesantes que le conciernen a la humanidad. El suicidio es un asunto especial y de permanente discusión acerca de la naturaleza humana que, por extraño les resulte a algunos, forma parte de las aspiraciones esenciales de la humanidad para su autoconocimiento. Muestra de esto son las múltiples reflexiones y pensamientos por parte de intelectuales de diferentes esferas de conocimiento a lo largo de la historia.

Dicho esto, es de vital importancia dejar en claro al lector los siguientes puntos que sostendré a lo largo del presente texto:

1. Mostrar que la temática del suicidio está al alcance de todos y no está reservado para unos pocos intelectuales selectos en la materia. No sólo eso, también pretendo demostrar que la comprensión de este comportamiento tan particular no es de acceso exclusivamente para aquellas personas que han intentado suicidarse o de quienes hayan tenido experiencias cercanas con personas suicidas.

2. Reiterar que el análisis y estudio psicológico del comportamiento suicida (y de cualquier otro comportamiento psicológico) debe realizarse fundamentalmente con base en dos criterios: a) la claridad conceptual de los términos que usamos para referirnos a los fenómenos psicológicos, y b) con base en una teoría sistemática y coherente que permita cumplir las metas que pretende toda ciencia.

3. Hacer énfasis, como muchos otros autores ya lo han hecho, respecto a que el suicidio es una conducta tan natural como cualquier otro fenómeno de la naturaleza de orden físico, químico, biológico y social. Es decir, no hay nada de sobrenatural ni contranatural en este comportamiento esencialmente humano. De hecho, este libro es también una invitación a discutir, desde una perspectiva científica, con toda tranquilidad y desahogo este tema tan estigmatizado aún en pleno siglo XXI.

Asimismo, quisiera ser claro en lo que este escrito no pretende abordar. En primer lugar, no tiene por objetivo ser una guía didáctica especializada en la prevención o tratamiento del suicidio, por consiguiente, el lector no encontrará técnicas o procedimientos psicológicos, psiquiátricos o afines para solucionar la problemática del suicidio en el terreno de la "salud mental". Sin embargo, el sistema psicológico descrito posibilita perfectamente la derivación de estrategias originales y efectivas para la prevención y tratamiento a personas con tendencias suicidas. 
En segundo lugar, el interés de este escrito en el suicidio no se ocupa únicamente en la búsqueda de alguna metodología típica de laboratorio para su estudio científico. Por el contrario, delineo aspectos fundamentales para la elaboración de líneas de investigación básica del comportamiento suicida. Luego, es de esperarse que la generación de conocimiento que surja a partir de la propuesta de estudio descrita pueda derivar en diferentes desarrollos tecnológicos aplicados al comportamiento suicida que incidan de forma eventual con gran impacto en la vida cotidiana.

Y, en tercer lugar, no es un libro especializado u orientado únicamente a estudiantes, profesionales en psicología y expertos del área o tema en cuestión. Si bien, es altamente recomendable que se tengan nociones teóricas básicas en psicología para un análisis más crítico y detallado, no es un requisito indispensable para su comprensiva y amena lectura. En contraste, este escrito también está dirigido al público general que desee aproximarse al tema a partir de una visión científica de la psicología, por lo que hago uso del lenguaje coloquial para facilitar la comunicación de las ideas fundamentales que se elaboran a partir del lenguaje especializado de la disciplina, sin que esto acarré distorsionar los planteamientos que propone la disciplina. Si el lector desea profundizar en algún punto en específico puede remitirse a las fuentes originales citadas en el escrito.

El propósito en el presente texto es brindar una visión del suicidio diferente a la tradicional que aún hoy día sigue siendo dominante en la investigación psicológica. Por un lado, me alejo de la imagen dualista del hombre (mente-cuerpo, espíritu-materia, mente-cerebro, etc.) y me apropio de una visión naturalista libre de "fantasmas" o de entidades hipotéticas que supuestamente explican los eventos de naturaleza psicológica de los organismos, particular aquella que tiene que ver con el ser humano.

Por otro lado, me interesa exponer la necesidad y ventajas de la investigación psicológica con énfasis en el control del suicidio entendido en este texto como la manipulación de diferentes factores que constituyen los episodios psicológicos para la promoción de dicho comportamiento con fines científicos. Tal vez, este sea el punto más importante que quisiera proponer para discutir tanto con el experto en psicología como para quien se inicia en el tema: cualquier control del comportamiento suicida, tal y como lo acabo de definir, es justificable siempre y cuando sea con el propósito de alcanzar una mayor comprensión de este fenómeno desde la psicología.

Desarrollaré este punto desde un ángulo distinto de aquella psicología que se inserta en el pensamiento científico como modo de conocimiento particular y que, por ende, posee un potencial tecnológico único. Justamente es esta clase de psicología la que está en condiciones de contribuir en el entendimiento del comportamiento suicida.

En resumen, lo que tiene el lector en sus manos es una propuesta de un sistema teórico de psicología científica que puede aportar fundamentos útiles en el estudio del comportamiento suicida, así como el posible desarrollo de las tecnologías únicas y efectivas para su aplicación en la modificación de este comportamiento en la vida diaria. Adicionalmente, expreso algunas reflexiones e inquietudes personales en torno al potencial tecnológico para el comportamiento suicida, ya sea por intereses de investigación en la comunidad científica o por intereses individuales.

No sobra que mencione y deje en claro que soy psicólogo con una formación muy particular dentro del Análisis Experimental de la Conducta y en la investigación del Desarrollo Psicológico General. No soy de ninguna manera un especialista en el área clínica ni de la salud. No obstante, lo anterior no me impide de ninguna manera hacer una lectura útil del comportamiento suicida para los profesionales o especialistas en asuntos clínicos que atienden dicha problemática social desde sus consultorios e instituciones de salud. Por el contrario, los diferentes análisis que 
desarrollaré en este escrito son una condición necesaria y de mayor importancia para llevar a cabo cualquier tipo de tratamiento clínico o terapéutico de forma efectiva.

Los colegas provenientes de las distintas concepciones psicológicas como la cognitiva-conductual, conductista, histórico-cultural, entre otras, han realizado valiosas investigaciones en el tema y han aportado mucho acerca de lo que hoy sabemos del suicidio. Así, también, lo han hecho las interdisciplinas tales como la psicobiología o la psicosociología. Siguiendo esta misma línea de contribución del conocimiento, tengo la oportunidad de aportar ideas que no se han tratado y desarrollado con profundidad, esto, desde el punto de vista particular de la Psicología Interconductual.

Debo mencionar también que, no tengo una formación profesional como filósofo, antropólogo, biólogo, sociólogo o en aspectos jurídicos, ni mucho menos. Por ello, no profundizo demasiado en el punto de vista de estas disciplinas cuando abordo la temática. Sin embargo, necesariamente hago mención de ellas, de una u otra forma, dadas las diversas esferas disciplinarias involucradas en el tópico del suicidio que han influido de forma notable con sus explicaciones.

Si bien, es cierto que todo estudio del suicidio resulta incompleto si es analizado y discutido desde el punto de vista de una sola disciplina, el contenido de la presente obra está pensada y anclada desde la Psicología, ciencia considerada como uno de los pilares centrales para explicar esta forma de comportamiento desde un nivel de análisis específico de la realidad.

Por último, tengo que decir que el contenido del presente texto no es más que una idea, tan sólo eso. Una idea que pretende ser diferente a las propuestas que hasta hoy en día existen alrededor del suicidio. Aclaro que la meta principal no es convencer a quien lee estas palabras. El propósito es la reflexión y discusión por parte del lector a partir de la propuesta descrita, pues recordemos que el tema del suicidio ha sido, es y será un tópico del que nunca tendremos respuestas absolutas ya que no existen las preguntas finales. El suicidio es uno de esos temas de la condición humana que son eternos y no le pertenecen a alguna disciplina en particular.

En coherencia con lo anterior, el presente libro no es una obra acabada ni definitoria. En todo caso, se le puede considerar como un texto hecho para pensarse, ya sea construyéndolo o destruyéndolo. Todo, menos ignorarse. Es solamente una propuesta a desarrollarse para posible interés del lector. 


\section{INTRODUCCIÓN}

Antes de adentrarme al tema en cuestión, me voy a permitir expresar algunas palabras acerca de la actitud que considero debemos de asumir al encarar los problemas dominantes en psicología. Lo único que pretendo con esto es recuperar aquella actitud responsable y crítica que es difícil de encontrar actualmente en la mayoría de las actividades de investigación y profesional en los psicólogos de nuestro país.

El mundo se encuentra lleno de prejuicios y confusiones acerca de nuestra realidad. Paradójicamente, en la tan anhelada "sociedad del conocimiento" parece existir todo, menos conocimiento. Sólo basta comparar nuestra sociedad con las anteriores en los aspectos intelectuales para percatarse que, después de civilizaciones antiguas como la egipcia, mesopotámica, griega, china y las culturas mesoamericanas, por mencionar algunas, son pocas las ideas realmente originales. Se cree que en el "siglo de la información y el conocimiento" existe un mayor desarrollo intelectual y facilidad para su acceso sin importar su ámbito.

Sin embargo, al contrario de lo que se piensa, no hay una mejora en la calidad del conocimiento y su difusión no ha tenido el impacto que supuestamente debería tener en la mayoría de la población en el planeta. Los desarrollos tecnológicos especializados para almacenar, reproducir y distribuir el conocimiento, tales como el internet (en especial las redes sociales ${ }^{1}$ ), redes de telefonía y televisión, no se han generalizado con eficacia en todo el mundo. Tan sólo por mencionar, según datos de la World Internet Project (WIP), apenas en el año 2013 dos tercios de la población mundial no tenían acceso a redes informáticas, esto es, un poco más de cinco millones de personas imposibilitados de navegar en la internet de forma gratuita (World Internet Project, 2013). En México, apenas un poco más de la mitad de los habitantes puede navegar en la web y otra gran parte tiene accesos limitados a las redes de telefonía (González, 2016; Asociación Mexicana de Internet, 2017).

$1 \quad$ Posiblemente las redes sociales, en especial Facebook y Twitter, sean las herramientas de comunicación más utilizadas en la actualidad para la difusión de cualquier tipo de conocimiento. Sin embargo, estas redes también han servido para divulgar una inmensa cantidad de información de contenido irrelevante que lo único que hacen es confundir a las personas y trivializar la información realmente valiosa.

Al respecto, recomiendo el libro Fraudebook de Vicente Serrano (2016) quien plantea los posibles efectos inadvertidos con el uso de las redes sociales en la normalización del pensamiento y sus múltiples implicaciones en la forma en que nos vinculamos de manera afectiva con estas plataformas virtuales. 
La mayoría de las personas que tienen acceso al "conocimiento" no van más allá de repetir lo que ya se ha dicho, y no me refiero al trabajo de divulgación. De hecho, estas mismas personas se han encargado de convertir las ideas complejas en meras opiniones incompletas y sin fundamento. O peor aún, lo único que han hecho es distorsionar las pocas ideas coherentes que se han elaborado a lo largo de la historia. No hay una genuina intención de generar algo nuevo. Los increíbles avances tecnológicos han creado la ilusión del progreso de ideas que pretenden solucionar problemas de orden mundial. No obstante, más que solucionarlos, lo que hemos creado son falsos problemas. Creemos estar planteando interrogantes novedosas y originales, cuando en realidad no nos percatamos que solamente se tratan de viejos problemas que están disfrazados de una terminología "moderna”. ¡Qué lejos nos encontramos de aquellos ideales del Renacimiento o de la Ilustración, en el que los hombres mantenían un interés permanente por los aspectos más esenciales de vida humana! Hoy en día son pocos los que se atreven a cuestionar de forma seria y profunda los temas más elementales e importantes de la inquietud humana, tales como la libertad, la verdad, el tiempo, la belleza, la justicia y, por supuesto, el tema que nos interesa aquí, el suicidio.

En la actualidad, vivimos en un tiempo en que el ser humano se encuentra envuelto por un sistema político y económico capitalista clientelar que poco promueve el pensamiento crítico y la reflexión acerca de las cuestiones fundamentales del mundo que construimos. Hemos privilegiado la satisfacción individual e inmediata por encima del entendimiento de las causas que nos hacen actuar de esa manera. Fuera del ámbito académico nadie se atreve a dudar, por consiguiente, es de esperarse que sean pocas las personas que se aventuren y se arriesguen a realizar propuestas audaces y originales. En todo caso, las formas dominantes de pensamiento y acción en nuestro tiempo se dirigen a asuntos pragmáticos con la finalidad de producir y acumular riqueza para cierto sector de la sociedad que contribuye al crecimiento de la pobreza, desigualdad, injusticia y deterioro del mundo.

Me detendré un momento en un par de puntos de suma importancia que he mencionado en el párrafo anterior: la crítica y el cuestionamiento de ideas. En la realidad no hay obviedades. Nada es evidente. En todo lo que se nos presenta como algo obvio o natural se esconde algo más profundo de lo que aparenta, más de lo que se puede apreciar a primera vista. No se trata de algo oculto de orden trascendental, espiritual o místico, sino de una cuestión de "caos" de naturaleza humana que se concreta como la expresión de los intereses de unos pocos. Estoy firmemente convencido en la necesidad de poner todo bajo sospecha y cuestionamiento ya que es una responsabilidad para con el otro, pero sobre todo para con uno mismo, si queremos generar ideas originales para cambiar el mundo en el que vivimos. Debemos cuestionar todo si queremos mantener una seria distancia con la mediocridad intelectual y el pensamiento cómodo que se encuentra en la mayoría de los individuos que viven felizmente en ese estado de indiferencia, sin preocupación alguna. Es imprescindible tomar una postura crítica y comprometida con el pensamiento intelectual de ideales propios que nos alejen de aquella mezquindad humana.

No hay nada más estimulante que repensar ideas establecidas y separarse del resto de individuos que carecen de una personalidad crítica, tal como lo describió a la perfección el argentino José Ingenieros en su obra El hombre mediocre. Debemos promover un cambio de raíz en nuestra forma de actuar: de una actitud vulgar a una actitud que implique pensar en el progreso del conocimiento. Debemos combatir todo tipo de cinismo e ideas falsas, como aquella que sostiene la imposibilidad de modificar determinadas situaciones, eventos o cosas de la realidad. Hay que pugnar contra este pensamiento falaz que promueve una actitud de quietismo, de permanecer en nuestros lugares 
como simples espectadores, mientras contemplamos el "orden natural" del mundo. Como si lo único que pudiéramos hacer fuese ajustarnos a las situaciones y nada más. Esta idea, falsa y peligrosa, de una realidad que se encuentra ya determinada, imposible de modificar, no es otra cosa que la representación de los intereses de una clase social que pretende el mejor de los mundos posibles sólo para sus propios beneficios.

En pocas palabras, hay que retar la lógica convencional, aunque ello implique quedarnos solos. Hoy, más que nunca, es necesario retomar aquel mensaje que guarda en sí mismo la duda cartesiana: hay que dudar de todo discurso de la autoridad y de las ideas vigentes. En palabras del propio René Descartes: "Para investigar la verdad es preciso dudar, en cuanto sea posible, de todas las cosas". Esta actitud es más afortunada en nuestros tiempos, esto es, una actitud rebelde y crítica frente al mundo prejuicioso y confuso que hoy vivimos. Dejemos de naturalizar las ideas que los demás necesitan que las hagamos como propias para que éstos triunfen y nos dominen. Rompamos con los valores utilitarios dominantes y mantengamos una permanente desconfianza frente a lo establecido.

Claro, no es nada sencillo tomar una actitud rebelde y desafiar las ideas más elementales de la noche a la mañana. Todos llegamos al mundo y nos topamos con un lugar que parece que ya tiene todo hecho: un idioma que se habla y terminaremos por hablarlo, una ideología que terminará por dominarnos, reglas, lógicas, creencias y actitudes que acabaremos por aceptarlas como si fueran algo natural o de sentido común. No obstante, a pesar de todos estos factores que condicionan la forma en que pensamos y actuamos, hay un momento en el que todo individuo debe decir su propia palabra con cierto distanciamiento de la situación en la que se encuentra: nuestra voz como un ser pensante particular y único.

El mundo está en constante transformación y debemos de elegir si queremos ser partícipes en él o no. Tenemos que elegir si estamos dispuestos a dejar huella, aportar ideas y generar acciones de cambio, dejando de lado el conformismo, o simplemente aceptamos de forma sumisa las ideas y reglas de los demás.

$\mathrm{Si}$ asumimos con responsabilidad cada una de nuestras elecciones, entonces es claro que no podemos dejar que alguien más elija por nosotros en los cambios del mundo. Como dijo alguna vez el escritor británico George Orwell: "No es posible que una persona pensante viva en nuestra sociedad sin quererla cambiar”. Pero, ¿cuáles deben ser nuestras elecciones? Propongo que sean todas aquellas con base en el conocimiento, la razón y el bien común para todos. No hay que olvidar que no existe un verdadero progreso humano si éste no se desarrolla a partir de una base racional y humanitaria, aun cuando en ocasiones se atente contra la propia razón y humanidad. Esas serán nuestras decisiones iniciales, mas no finales, que nos llevarán hacia adelante, hacia el saber y el progreso.

Si recordamos las palabras del filósofo Aristóteles, éste comienza en su primer libro de la obra Metafísica diciendo lo siguiente: “Todos los hombres por naturaleza desean saber”. En efecto, siempre queremos saber más pues, entre otras cosas, el ser humano nunca está satisfecho con muchas respuestas que ofrece el mundo. Personalmente, no estoy satisfecho con muchas respuestas que me han planteado como verdades absolutas. No sólo eso, no estoy conforme sobre cómo se han manejado ciertos temas actuales. Entre esos temas y respuestas que me han planteado como una realidad irrefutable, a modo de letanías, se encuentran aquellas acerca del tema que abordaré en las siguientes páginas. Estoy convencido de que todos aquellos que comparten conmigo aquellas inquietudes que cuestionan y ponen en tela de juicio lo más evidente es muestra clara de cierto grado de toma de conciencia sobre las cosas que nos rodean en el mundo. 
Ahora bien, ¿qué tiene que ver todo lo anterior con el tema que aquí interesa? ¿por qué y para qué hablo del cuestionamiento de ideas y actitudes rebeldes? Porque el tema de interés del presente escrito gira en torno a un tópico fundamental del ser humano del que no podemos ser indiferentes, por el contrario, debemos ser bastante críticos haciendo frente a las ideas vigentes, derribando sus mitos y elaborando propuestas novedosas.

El suicidio es un tema de carácter fundamental porque nos remite a diversas cuestiones esenciales de la condición humana. Y como asunto fundamental del ser humano, no es ninguna sorpresa que la filosofía se adelantara a cualquier otro modo de conocimiento en expresar los diversos pensamientos y sentimientos que experimentan aquellos que incurren de manera cercana en el suicidio.

Una de las preguntas fundamentales, que inició con la filosofía de hace más de 200 años a. C. hasta la ciencia de nuestros días, ha sido ¿por qué las personas se suicidan? Esta pregunta es tan vieja como la misma humanidad, pero aun sin una respuesta absoluta. Sin adelantarme a ofrecer una respuesta, considero que el mejor inicio para adentrarnos al tema es conceptualizarla como una elección personal.

Todas las personas tomamos decisiones de manera constante. No elegimos en ocasiones o con cierta frecuencia, por el contrario, siempre estamos eligiendo libremente. Somos libres a la fuerza porque no podemos dejar de optar en cada instancia de nuestra vida. Paradójicamente, no somos libres de dejar de ser libres. Como dijo alguna vez el genio filósofo francés Jean-Paul Sartre: “Estamos condenados a ser libres". Se elige vivir en un país y no en otro. Ser vegetariano o carnívoro. Casarse o estar soltero. Se elige estudiar una carrera y no otra, ambas o ninguna. Siempre estamos tomando decisiones, siempre estamos ejerciendo nuestra libertad. En cada elección se tiene cierta certeza, o por lo menos una vaga idea, de las consecuencias, de lo contrario no elegiríamos tal o cual cosa. Hacemos diversas acciones esperando ciertos resultados. Por ejemplo, estudiamos para un examen con cierta anticipación con el fin de obtener una excelente calificación. Optamos por casarnos esperando vivir el resto de nuestra vida con aquella persona que amamos.

No obstante, sabemos que pueden ocurrir una infinidad de cosas, es decir, puede que ni obtengamos una buena calificación en el examen para el que estudiamos arduamente durante meses, ni seamos felices con aquella persona que alguna vez creímos que lo seríamos al casarnos. Todos tomamos decisiones de forma constante y, con ello, nos arriesgamos. Con base en los resultados, y diversos factores de la situación, seguimos eligiendo hasta el fin de nuestros días. Nos vamos construyendo con cada uno de nuestros actos, nos vamos eligiendo.

Sin embargo, sabemos que el suicidio es un acto que ha elegido el ser humano desde tiempos inmemoriales y como resultado ya no habrá más elecciones posteriores. Precisamente, es esto lo bello de este aparente acto terrorífico: es el último y más importante acto de libertad que va a estructurar el sentido de nuestra vida.

Son demasiadas las interrogantes que existen alrededor del tema y de diferentes niveles de análisis (filosóficos, psicológicos, biológicos, sociales, etc.): ¿Por qué se elige el suicidio y no otra opción? ¿Cuáles son las condiciones necesarias y suficientes para que alguien cometa suicidio? ¿Qué hace diferente al suicidio de otras conductas? ¿Cuál es el problema de que la gente se suicide? ¿Cómo debemos entender las acciones suicidas? ¿El suicidio es un problema o una solución? ¿Qué valoración o papel desempeña la vida y la muerte en todo esto? ¿En el suicidio se está atentando contra la vida o más bien se está reafirmando el valor de la vida? ¿Cuál es el límite que separa el suicidio altruista y el suicidio depresivo? ¿Es un fenómeno individual o social? ¿Cuántos tipos de suicidios existen? ¿Qué función tiene 
el suicidio en la naturaleza? ¿Para que un suicidio sea valorado como tal depende del nivel de conciencia e intencionalidad de quién lo realiza? ¿Qué papel juega el cerebro en todo esto? ¿Somos libres de suicidarnos o estamos condicionados por diversos factores? ¿Por qué en ocasiones la gente falla al suicidarse? ¿Deberíamos seguir pensando que es prevenible el suicidio cuando va en aumento el número de suicidas en el mundo? ¿Es posible provocar deliberadamente el suicidio en una persona? No pretendo dar respuestas absolutas a las preguntas anteriores pues es imposible. Sin embargo, es necesario posicionarnos en el tema, dar respuestas tentativas y articular un discurso coherente, en este caso siempre enmarcado desde la psicología.

Con base en todo lo dicho, los objetivos principales de este texto son cuatro: 1) mostrar el estado actual acerca del conocimiento que se tiene del suicidio con base en la investigación realizada hasta ahora desde las teorías psicológicas, 2) señalar las limitaciones teóricas y metodológicas de dichas investigaciones para su mejora en futuros estudios del suicidio, 3) describir una propuesta alternativa teórica de dichas teorías que contribuya al estudio del suicidio de una forma más coherente, y 4) describir una tecnología psicológica derivada del modelo interconductual con el fin de llevar a cabo el control del suicidio para la generación de planteamientos novedosos en la investigación científica.

En función de los objetivos anteriores, la presente obra está conformada de la siguiente manera:

En el primer capítulo, se exponen brevemente algunas de las perspectivas y las explicaciones que se han proporcionado a lo largo de la historia acerca del suicidio. Se hace un recorrido histórico con los diferentes pensamientos filosóficos de la Antigua Grecia, pues tienen el privilegio de ser la base sobre la cual se construyeron las diferentes concepciones que hasta hoy en día tenemos acerca del suicidio. Después, se señala la importante influencia que tuvo la religión cristiana y las teorías científicas modernas, para así finalizar con la perspectiva dominante del suicidio en el ámbito de la salud, especialmente en el área de la psicología.

En el segundo capítulo, se realiza un análisis del suicidio desde diferentes propuestas psicológicas. Para ello, se describen brevemente algunas de las teorías más importantes en el tema, señalando sus supuestos básicos y las explicaciones que han brindado al respecto. Asimismo, se puntualizan sus respectivas problemáticas teóricas y metodológicas.

En el tercer capítulo, se realiza un necesario análisis conceptual del término suicidio que permita proporcionarnos la suficiente claridad para la elaboración de planteamientos coherentes en nuestro quehacer científico y tecnológico en psicología.

En el cuarto capítulo, se describe la propuesta alternativa para el estudio del suicidio desde una psicología científica, es decir, la Psicología Interconductual propuesta por Jacob Robert Kantor (1978). Pero, antes, se proporciona una definición general de ciencia, su propósito, su metodología general y las características más sobresalientes, esto con el objetivo de adentrar al lector a la lógica de este particular modo de conocimiento.

En el quinto capítulo, se expone el estado actual de la investigación del suicidio en psicología y los tipos de intervenciones tecnológicas derivadas de dichas investigaciones. También, se señalan los alcances y limitaciones que poseen éstas. Por último, se describe una propuesta tecnológica psicológica alternativa, derivada del modelo interconductual para el control del suicidio y el diseño de estrategias para la promoción de este comportamiento.

En el sexto capítulo, se expresan algunas reflexiones personales en torno al control del suicidio y su utilidad en la vida cotidiana para aquellas personas ajenas a las actividades científicas. En este último capítulo, se busca justificar 
la aplicación del control del suicidio y responder a interrogantes íntimamente vinculadas con el por qué y para qué desde puntos de vista que escapan a los criterios que rigen al interior de la psicología, tales como la ética y la moral.

Debo advertirle al lector que el orden de los capítulos tiene un hilo conductor que organiza al texto de lo general a lo específico. No obstante, a lo largo del escrito encontrará que retomo algunas ideas ya expuestas en otros capítulos en la medida en que se avanza en la lectura. Esto es así ya que he procurado la posibilidad de realizar una lectura relativamente autónoma entre cada capítulo, sin que esto signifique que estos estén desvinculados. 


\section{CAPÍtUlo 1}

\section{Antecedentes históricos y filosóficos del suicidio}

No hay sino un problema filosófico realmente serio: el suicidio. Juzgar si la vida vale o no vale

la pena de vivirla es responder a la pregunta fundamental de la filosofía.

Albert Camus

El suicidio no es de ninguna manera un tema nuevo del que debamos sorprendernos, por el contrario, es algo que ocurre todos los días. Generalmente, se le ha intentado ocultar por lo trágico de la situación o dado un trato secundario en la sociedad con el fin de evitar su discusión. Sin embargo, a pesar de ser un tema eludido en la mayoría de las conversaciones cotidianas, no se le ha podido negar ni dejar de lado. Desde hace tiempo, se le ha tachado, estigmatizado y despreciado en casi todas las sociedades, pero también, y por increíble que le parezca al lector, se ha justificado en favor del suicidio por parte de intelectuales de todos los tiempos. Esto obedece, entre otras cosas, a que ha sido abordado desde diferentes perspectivas, pues el tópico no constituye de ningún modo un asunto propio y exclusivo de alguna disciplina en particular. Por lo tanto, es de esperarse una gran variedad de puntos de vista antagónicos entre sí y, en algunos casos, imposibles de conciliar.

La filosofía es la primera en ocuparse del suicidio de manera crítica, mediante el cuestionamiento y la formulación de preguntas acerca de las causas, implicaciones y problemáticas en dicho acto. La filosofía se ha caracterizado por ser el conjunto de saberes que pretende establecer racionalmente los principios generales que organizan y orientan el conocimiento de la realidad, así como el sentido del obrar humano. No profundizaré en la problemática de la definición del objeto de estudio de la filosofía, pues definir o determinar con exactitud qué es la filosofía requiere de una labor tremendamente difícil y escapa a los propósitos del texto. Lo que sí es necesario aclarar es que, más que una filosofía, existen varias filosofías, por lo tanto, diferentes formas de hacer filosofía y de conceptualizar al suicidio. Me quedaré con la idea general de la filosofía, como aquella disciplina encargada de plantear los problemas fundamentales de ser y el mundo, por ejemplo, el conocimiento, la moral, la mente, el amor, el lenguaje y, entre ellos, podemos encontrar el tema que nos incumbe, el suicidio. 
¿Qué tienen que decir las diversas filosofías al respecto? Mucho es lo que han dicho y solamente se pueden entender a través de un recorrido histórico a través de los diferentes pensamientos y reflexiones de pensadores de diversas épocas que se han visto influenciados unos con otros hasta llegar a las conceptualizaciones actuales, en particular, la concepción que se tiene desde la psicología.

\section{Periodo de la Antigua Grecia}

Cualquier persona con un profundo y serio interés en el tema del suicidio se verá obligada en algún momento a realizar un recorrido histórico del mismo. El motivo de esto va más allá del simple, pero no menos importante, registro historiográfico de datos y hechos del pasado en el que se reconocen personajes, obras y fechas. Por el contrario, también implica conocer su origen y fundamento, de tal manera que el estudio historiográfico se vuelve una herramienta eficaz para ayudarnos en la comprensión y desarrollo de las conceptualizaciones actuales del suicidio. ¿Por dónde comenzar? Sin duda, tendríamos que empezar en la Antigua Grecia con los grandes pensadores de la época, particularmente con los escritos de Platón, Aristóteles y Séneca.

Platón (427-347 a.C.) fue un extraordinario filósofo y matemático griego, maestro de Aristóteles. Escribió diálogos filosóficos de gran trascendencia e influencia en la retórica y filosofía en general. Dichos diálogos representan algunas de sus máximas obras. En los diálogos Apología de Sócrates y Fedón, Platón relata el proceso de la tan conocida condena a muerte y suicidio de su maestro Sócrates con la cicuta. En estos diálogos, encontramos los primeros argumentos que se hayan escrito que justifiquen el suicidio.

En Apología de Sócrates se nos relata que tres ciudadanos, Melito, Anito y Licón, acusan a Sócrates de corromper a la juventud con sus enseñanzas, de insultar a los dioses e introducir nuevas divinidades en la ciudad. Sócrates es llevado a juicio y decide, como se acostumbraba en aquellos tiempos, ser su propio defensor ante jueces y espectadores. Durante el juicio, logra defenderse de manera extraordinaria. Sin embargo, la escasa mayoría de los jueces lo declaran culpable. Para definir la pena, el jurado debe elegir entre la propuesta de los acusadores, quienes proponen la muerte, y la propuesta del acusado, quien propone ser alojado y alimentado en Pritaneo. El jurado elije la muerte para Sócrates. Es condenado, injustamente, a beber cicuta y, así, morir por suicidio. Algunos estudiosos consideran que se trata de un auténtico suicidio porque Sócrates pudo haber huido de la ciudad de Atenas, sin ningún problema, meses antes de que bebiera la cicuta, pues no fue encarcelado de forma inmediata una vez dada la sentencia. Incluso, tuvo oportunidad de huir, ya encarcelado, un día anterior a su muerte pues sus discípulos sobornaron al guardiacárcel para que se le dejara escapar de la celda. No obstante, Sócrates, fiel a sus principios éticos, decidió afrontar la muerte y permanecer de forma voluntaria en su celda, sin escapar, siendo consciente de su inocencia, tal y como se cuenta en otro relato, Fedón.

En Fedón se narran los últimos momentos de Sócrates donde mantiene una conversación con sus discípulos acerca de la vida que debe llevar un filósofo y de la inmortalidad del alma. Sócrates les dice que los verdaderos filósofos deben de vivir para morir y alcanzar así la verdad, pero que es ilícito el acto del suicido. Cebes, uno de sus discípulos, le cuestiona al respecto: 
— Pues bien, dijo Sócrates, Eveno me seguirá como todo hombre que se ocupa dignamente en filosofía. Sé bien que no se suicidará, porque esto no es lícito.

Diciendo estas palabras se sentó al borde de su cama, puso los pies en tierra, y habló en esta postura todo el resto del día. Cebes le preguntó:

— ¿Cómo es, Sócrates, que no es permitido atentar a la propia vida, y sin embargo el filósofo debe seguir a cualquiera que muere? (Platón, 1979, p. 390)

Sócrates le aclara a Cebes que la meta de un filósofo es alcanzar la verdad, la cual sólo es posible después de la muerte, pero la muerte por sí misma no garantiza que se llegue a la verdad. El suicidio no es un atajo para alcanzar la verdad. La muerte es una condición necesaria, pero no suficiente para alcanzar al conocimiento. Únicamente aquella persona que haya filosofado a lo largo de su vida podrá adquirir el conocimiento, y con la llegada de la muerte alcanzar la verdad. Cuando la persona adquiere el conocimiento puede suicidarse si lo desea. No hay ninguna contradicción entre la prohibición del suicidio y llevar a cabo el suicidio de esta forma.

Toda acción racional humana va dirigida hacia el bien, dice Sócrates, y la muerte es un bien máximo para el filósofo. Con la muerte se alcanza la verdad, pero es ilícito suicidarse sin haber filosofado. Para la vida de un filósofo como Sócrates, que siempre buscó el conocimiento y la verdad, quitarse la vida fue un acto justificado como un bien legítimo, visto filosóficamente claro está.

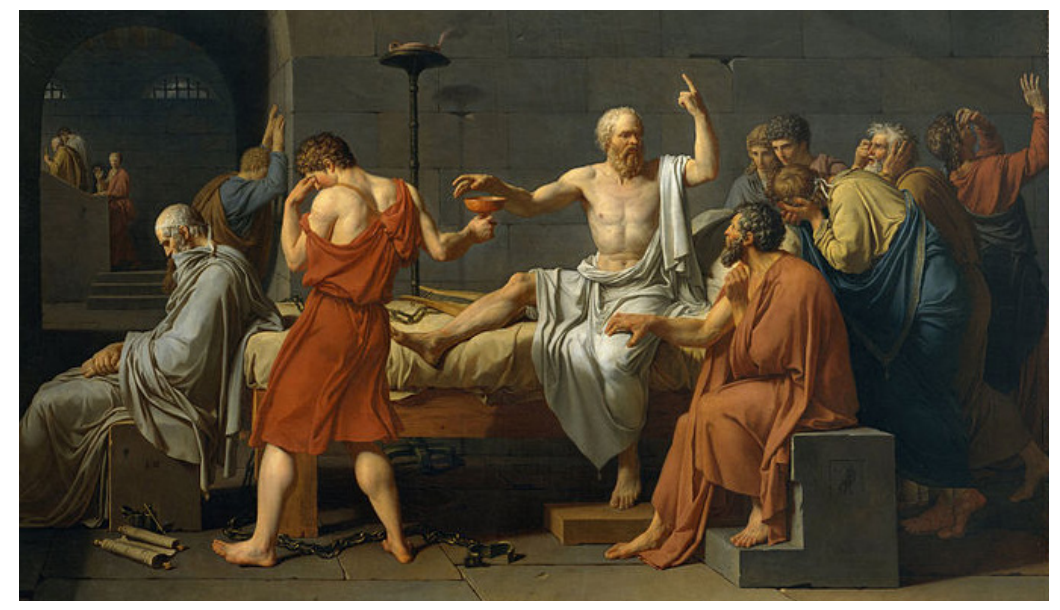

Figura 1. La muerte de Sócrates (detalle) (Jacques-Louis David, 1787). La obra representa la escena de la muerte de Sócrates, condenado a morir bebiendo cicuta por haber expresado sus ideas en contra de la creencia de los dioses ancestrales y corromper a los jóvenes de Atenas.

Por otro lado, en la obra Las Leyes, Platón se opone al suicidio y propone algunas normas de castigo para distintos casos de homicidios y parricidios, incluyendo los suicidios. He aquí sus célebres palabras:

El que mate al más próximo y del que se dice que es el más querido de todos, ¿qué pena debe sufrir? Me refiero al que se mate a sí mismo, impidiendo con violencia el cumplimiento de su destino, sin que se lo ordene judicialmente la ciudad, ni forzado por una mala suerte que lo hubiera tocado con un dolor excesivo e inevitable, ni porque lo aqueje una vergüenza que ponga a su vida en un callejón sin salida y haga imposible de ser vivida, sino que se aplica eventualmente un castigo injusto a sí mismo 
por pereza y por una cobardía propia de la falta de hombría. En todo lo demás, los dioses conocen los ritos que éste necesita para las purificaciones y su sepelio, ritos a cuyos intérpretes deben consultar los parientes más próximos y a las leyes que los regulan y hacer lo que ellos les manden. Pero las tumbas para los muertos de esta manera deben ser, en primer lugar, particulares y no compartidas con otro. Además, deben enterrarlos sin fama en los confines de los doce distritos en aquellos lugares que sean baldíos y sin nombre, sin señalar sus tumbas con estelas o nombres. (Platón, 1999, pp. 167-168)

Todo aquel que cometía suicidio no merecía ningún respeto, sin importar los motivos. No obstante, el suicidio en la Antigua Grecia podía ser legítimo cuando se solicitaba y se exponían los suficientes argumentos ante un Senado para justificarlo. Los argumentos eran variados y siempre escuchados por las autoridades griegas. Por ejemplo, se creía que los dioses eran quienes cuidaban de nosotros, y nosotros éramos una posesión de ellos. Así pues, si uno recibía señales de los dioses que indicaran que se debe cometer suicidio, entonces se estaba autorizado en hacerlo (Brown, 2001).

Más adelante, veremos cómo el cristianismo, en la Edad Media, explicitaría castigos similares a los propuestos por Platón para todas las personas suicidas.

Por otro lado, Aristóteles (384-322 a. C.) coincide parcialmente con su maestro Platón y asume una posición contraria a la de Sócrates. Aristóteles, orgulloso del arte y la sabiduría de su pueblo, consideraba que el suicidio era doloroso y un crimen contra la propia vida, además de ser una expresión de cobardía y deshonra personal. Específicamente, más que un crimen contra uno mismo, era un atentado contra la ciudad y la sociedad a la que pertenecía. En su escrito Ética Nicomaquea, menciona lo siguiente:

Si puede o no cometerse injusticia consigo mismo, es patente por lo que queda dicho. Porque entre los actos justos están los actos conformes con todas las virtudes y prescritos por la ley. Por ejemplo, la ley no autoriza a darse la muerte, y lo que la ley no autoriza, lo prohíbe. A más de esto, cuando con violación de la ley uno causa un daño a otro (como no sea para devolver el daño recibido) y lo hace voluntariamente, es reo de injusticia, entendiéndose que el agente voluntario es el que sabe a quién y con qué daña. Mas el que por cólera se da de puñaladas, lo hace voluntariamente y contra la recta razón, lo cual no lo permite la ley; por lo tanto, comete una injusticia. Pero ¿contra quién? ¿No diremos que, contra la ciudad, y no contra sí mismo? Porque en cuanto a él, voluntariamente padece, y nadie sufre injusticia voluntariamente. Y por esto la ciudad castiga tales hechos, y cierto deshonor acompaña al que se destruye a sí mismo, estimándose que ha cometido una injusticia para con la ciudad. (Aristóteles, 2010, p. 97)

Es comprensible el pensamiento de Aristóteles pues, como es bien sabido, en la antigua Atenas se creía que una comunidad debía no solamente de satisfacer de manera eficaz las necesidades básicas de la vida individual, por el contrario, se consideraba que cada persona era responsable del bienestar de los individuos de la comunidad a la que pertenecía y, por ello, cada uno tenía la obligación de desarrollar al máximo sus facultades. 
El bien humano en general, sostenía Aristóteles, alcanza su punto más alto cuando éste rebasaba los límites de la individualidad. Procurar el bien del individuo es importante, sin embargo, es mayor y más perfecto alcanzar y preservar el bien de la ciudad. Así, se entiende que es meritorio hacer el bien a uno mismo, pero cuando se hace el bien al pueblo y a las ciudades es superior a cualquier otra cosa. Es decir, se vuelve excelso y puede llegar al máximo con belleza absoluta y divina cuando se hace el bien para los demás por la ciudad. En palabras de Aristóteles:

Y por más que este bien sea el mismo para el individuo y para la ciudad, es con mucho cosa mayor y más perfecta la gestión y salvaguarda del bien de la ciudad. Es cosa amable hacer el bien a uno solo, pero más bella y más divina es hacerlo al pueblo y las ciudades. (p. 4)
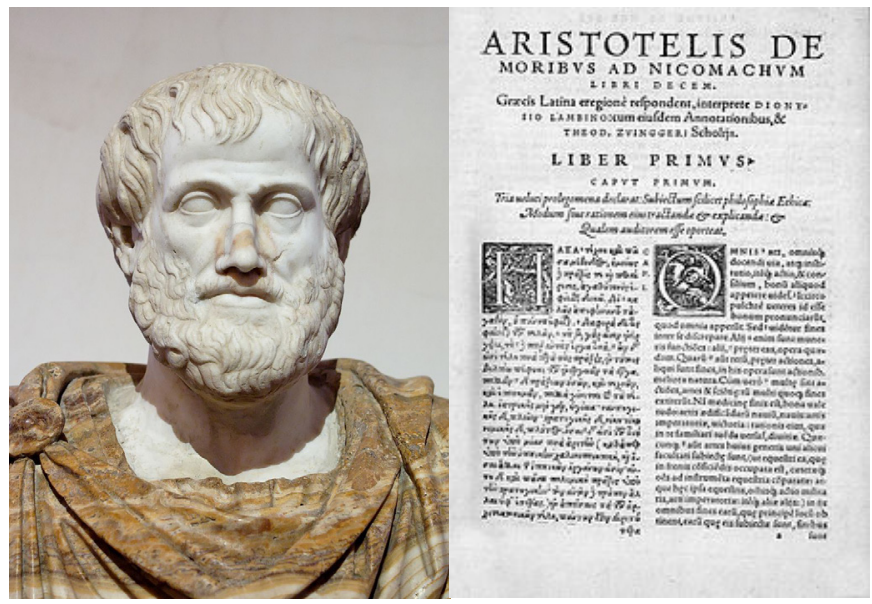

Figura 2. Busto de Aristóteles y su texto Ética Nicomaquea.

Por otro lado, el historiador, filósofo y político Séneca (4 a.C. - 65) sostenía una postura contraria a la de Aristóteles y afirmaba que la mejor cosa que ha hecho la ley eterna dictada por los dioses es habernos otorgado sólo una entrada a la vida y, sin embargo, miles de salidas, siendo una de ellas el suicidio. Séneca elaboró, entre varios de sus importantes escritos, una serie de cartas a Lucilio $^{1}$ quien era el procurador de la Cilicia (actualmente Turquía). En su carta LXX reflexiona sobre el suicidio y sostiene que es un acto de libertad al que se puede recurrir si se presentan muchas molestias que aturdan nuestra tranquilidad. Además, dice Séneca, si la muerte es inevitable en todos los seres vivos, entonces no puede ser un mal que tengamos que evitar a toda costa. Lo verdaderamente importante no es preocuparnos de cuándo vamos a morir, sino la forma en cómo morimos, es decir, cómo debemos llegar a la muerte:

Por otra parte, bien sabes que no es forzoso conservar la vida, pues lo importante no es vivir mucho sino vivir bien. Así, es que el sabio vive lo que debe y no lo que puede. Examinará dónde, cómo, con quién, por qué debe vivir; lo que será su vida, no lo que pueda durar. Si concurren circunstancias que

$1 \quad$ Actualmente se ha puesto en duda la existencia histórica de Lucilio pues no hay otra fuente histórica que lo mencione. Incluso aún hay dudas de que Séneca haya sido el autor original de dichas cartas. Sin embargo, lo que importa son las reflexiones que se hacen acerca del suicidio. 
le aflijan y turben su sosiego, dejará la vida; y no ha de esperar al último extremo para abandonarla, sino que el primer día en que empiece a desconfiar de la fortuna, deberá ser el último para él, aunque no sin pensarlo cuidadosamente. Darse la muerte o recibirla, acabar un poco después o un poco antes, ha de ser para él enteramente lo mismo; no hay en eso nada que pueda espantarle. ¿Qué importa perder lo que se nos va escapando gota a gota? Morir más pronto o más tarde es cosa indiferente; lo importante es morir bien o mal (Séneca, 1943, p. 217).

$\mathrm{Si}$ a uno le da la gana vivir o dejar de vivir es totalmente respetable volver al lugar de donde venimos, sobre todo si tiene sentido para el que pretende suicidarse. Así, lo relevante no es solamente vivir, sino vivir bien. Al final, todo recae en la calidad de la vida ${ }^{2}$. El pensamiento de Séneca coincide con el de Sócrates en el supuesto de que el sabio debe vivir cuanto debe y no cuanto puede. Si ya no se vive bien, entonces el suicidio es totalmente legítimo y de sabios hacerlo. Es legítimo, en tanto es fruto de una deliberación racional. Si es producto de nuestras pasiones, cólera, impulsos o emociones intensas, entonces es ilegítimo y una cobardía. Esta concepción del suicidio se nos presenta como un acto de suprema libertad que busca la felicidad y que es decretado por la razón.

El propio Séneca se suicidó cortándose las venas de brazos y piernas en una bañera caliente, mientras dialogaba con sus discípulos, quienes escucharon sus enseñanzas hasta su fin.
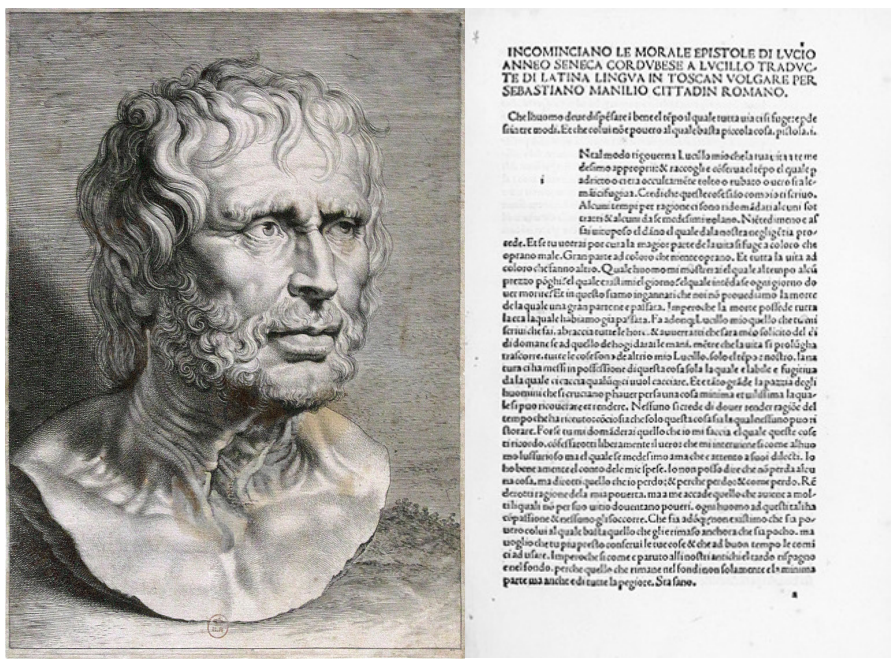

Figura 3. Séneca y su escrito Cartas a Lucilio.

Un filósofo griego adicional que no podemos pasar desapercibido, a pesar de estar olvidado por muchos académicos contemporáneos, es Hegesias de Cirene. En realidad, poco se sabe de él, no obstante, se sabe que fue conocido por sus recomendaciones o persuasiones a sus discípulos para que cometieran suicidio. Por esta razón, este filósofo también fue llamado como Peisithanatos ("Persuasor de la muerte"). Se oponía al fundamento principal de la escuela cirenaica que afirmaba que el placer es el objetivo universal, es decir, el goce como la finalidad de la vida.

2 A este pensamiento se le puede considerar precursor de lo que actualmente denominamos eutanasia, es decir, el bien morir de un paciente (generalmente en etapa final de una enfermedad) para evitar el sufrimiento con o sin su consentimiento. Hoy por hoy, se sigue debatiendo acerca de los límites de la eutanasia y el derecho a la vida. 
Hegesias se oponía porque se percató que en realidad son pocos los placeres que uno tiene en la vida y, por el contrario, son más los dolores y de mayor intensidad los que nos aquejan. Si esto es cierto, entonces cualquier persona que pretenda buscar los placeres caerá irremediablemente en el pesimismo, pues nunca encontrará el goce en las cosas por siempre. A Hegesias se le atribuye la siguiente máxima: "La felicidad es cosa absolutamente imposible, pues el cuerpo está aquejado de innumerables dolores, y el alma que participa en estos sufrimientos del cuerpo está también aquejada por los suyos porque la fortuna impide la realización de buen número de nuestras esperanzas y deseos; por esto la felicidad no posee existencia real".

Para Hegesias nuestra felicidad está ligada al placer, y dicho placer es inseparable de las condiciones orgánicas de nuestro cuerpo. Este filósofo encuentra en el suicidio la solución al inevitable deterioro del cuerpo que nos lleva a la infelicidad.

Es amplio el pensamiento de los filósofos griegos acerca del suicidio y se podría profundizar más con cada uno de ellos. Sin embargo, con lo dicho es suficiente para mostrar dos puntos:

1. No existía un pensamiento uniforme acerca del suicidio, por el contrario, había gran diversidad de ideas que no necesariamente coincidían entre ellas.

2. Toda propuesta o reflexión en torno al suicidio fue elaborada a partir de las diversas observaciones concretas de la naturaleza cotidianas (ver, oír, tocar, sentir, etc.).

Sin duda, la cultura griega generó ideas novedosas, no sólo en lo que incumbe al suicidio, sino en casi todos los ámbitos para sentar las bases para el pensamiento occidental. Sin embargo, todo vendría a cambiar con la llegada del cristianismo. Todas las ideas y conceptos originales de los grandes pensadores griegos sufrirían cambios radicales.

\section{Periodo de la Edad Media}

A partir de las grandes conquistas de Filipo II y de su destacado hijo Alejandro Magno, por toda Europa se generaron las condiciones para un cambio profundo en el estilo de vida social, económica y política. Después de la caída del Imperio romano de Occidente, se instaura el cristianismo como la religión oficial con la llegada al poder del emperador Teodosio I y se marcaría el inicio de una nueva etapa en la historia de la humanidad.

El cristianismo surgió y cambió para siempre el pensamiento de la humanidad. El dominio ideológico y moral del clero sobre la sociedad fue simplemente avasallador. Ninguna otra religión ha tenido el éxito, ni ganado tanto terreno para imponer una ideología que sistematice la forma de vida de todos como lo ha hecho el cristianismo. Todos los conceptos e ideas del pensamiento griego cambiaron de forma radical: la concepción del ser, del sentido de la historia, de la vida, del tiempo, del espacio, los valores morales, todo. ¿En qué sentido cambiaron? Las instituciones intelectuales pasaron a ser promotoras del pensamiento natural al transcendental. Trajeron consigo ideas místicas y espirituales que propiciaron las condiciones necesarias para escindir al ser humano de la naturaleza.

En nuestros días, es difícil separarnos del pensamiento cristiano por más ateos que nos consideremos. De hecho, son pocos los que se percatan del origen religioso de muchas de nuestras actividades e ideas actuales. Ni los grandes personajes de la filosofía, ciencia, arte e intelectuales en general han podido emanciparse de dicho pensamiento, incluyendo nuestros contemporáneos. 
Pero, ¿de qué trata el cristianismo y cómo se vincula con el suicidio? El cristianismo propone una ruptura entre el mundo natural griego y el celestial, esto es, proclama la trascendencia de la muerte y el alcance de la eternidad en otro mundo cualitativamente distinto. Claro, la idea de aceptar la muerte física y negar la muerte espiritual no es algo exclusivo del cristianismo. Más bien, ha sido una constante en casi todas las culturas de todas las épocas. Sin embargo, el cristianismo, a diferencia de otras religiones, garantiza la vida eterna en otro plano. De hecho, es aquí donde la mayoría de las religiones tienen su función más relevante: la promesa y esperanza de un mundo mejor, que solamente es alcanzable con el cumplimiento de una serie de reglas (mandamientos, leyes divinas, tributos, etc.) y culmina una vez llegada la muerte. Es necesario tener presente que la muerte es la piedra angular que sostiene a todo el pensamiento de la religión cristiana y a todas aquellas religiones que prometen una mejor vida en otro mundo que está más allá de lo terrenal. Esto no quiere decir otra cosa más que, de no existir la muerte, simplemente no habría religión alguna, pues justamente ésta es la plataforma que le otorga poder a las instituciones religiosas.

Siendo claro y sin ningún tipo de diplomacia o amabilidad en lo que refiere al pensamiento religioso. El ser humano sabe que ha de morir y al mismo tiempo tiene un infinito apego a la vida, lo cual es lógico. La vida es lo único que conocemos, mientras que la muerte es una certeza desconocida. Sin embargo, las autoridades religiosas nos hablan de la existencia de un lugar que llaman "el más allá", pero que ni ellos mismos conocen. De hecho, nadie lo conoce. Todo lo que podamos decir del "más allá" siempre lo diremos desde el "más acá", o sea, desde nuestro mundo terrenal. Nuestro apego a la vida y nuestro orgullo nos persuade a rechazar la realidad que Platón escribió en sus Diálogos:

mi querido Hermógenes, la mejor manera de examinar, si fuéramos prudentes, sería confesar que nosotros nada sabemos ni de la naturaleza de los dioses, ni de los nombres con que se llaman a sí mismos; nombres que, sin dudar, son la exacta expresión de la verdad. Después de esta confesión, el partido más razonable es llamar a los dioses, como la ley quiere que se les llame en las preces, y darles nombres que lea sean agradables, reconociendo que nada más sabemos. En mi opinión esto es lo más sensato que podemos hacer. (1979, p. 262)

El miedo a la muerte, a lo desconocido, es de lo que se valen las religiones para medrar asegurando que no todo acaba con la muerte y, con ello, instrumentalizar un miedo que ellas mismas provocan.

Ahora bien, ¿cuál es la relación del cristianismo con el suicidio? En las Sagradas Escrituras de la Biblia Cristiana se defiende la idea de que el ser humano se encuentra bajo la voluntad de Dios, pues es él quien da vida y muerte en todo el universo. Podemos encontrar en el Antiguo Testamento un pasaje de Deuteronomio, que refiere a una serie de discursos dirigidos por Moisés, que expresa esto que hago mención y en el que se subraya el dominio absoluto de Dios sobre la vida humana:

Ved que yo, sólo yo soy... Yo doy la muerte y la vida, hiero yo y sano yo mismo. (Dt 32,39)

Lo anterior, es una de las tantas expresiones que podemos encontrar en el texto bíblico y que nos muestra una visión del ser humano ajeno a su propia vida. Los hombres y mujeres no son dueños de sus vidas, por lo tanto, 
tampoco deben hacerse daño a sí mismos. Dios es quien da la vida y es el único que la puede quitar. De ahí que, durante la Edad Media, a partir del año 542, la Iglesia castigara a los suicidas, principalmente de tres formas:

1. Condena eterna en el infierno por medio de la no absolución del cuerpo del suicida.

2. Daño al cadáver del suicida (descuartizándolo y quemándolo en público).

3. Retiro de los bienes o pertenencias del suicida dejando sin propiedades a los familiares.

Actualmente, la Iglesia ya no castiga de esta forma, debido al surgimiento de las ideas racionalistas que fueron ganando terreno durante el Renacimiento y la Ilustración e influyeron de forma significativa al pensamiento dominante. Sin embargo, aún continúa sosteniendo que el suicidio es un pecado muy severo que insulta a Dios.

Pero, ¿por qué el suicidio se considera un pecado, si no se explicita nada semejante en los mandamientos bíblicos o en algún otro lado 3 ? Recordemos que los mandamientos bíblicos son una serie de órdenes que representan la palabra de Dios y se deben respetar obedeciendo al pie de la letra. El quinto mandamiento dice "No matarás" y hace referencia a la prohibición de matar a alguien que no sea uno mismo, pues de lo contrario el mandamiento sería "No matarás ni te suicidarás", o algo así. Ahora bien, en la medida en que el suicidio supone la muerte deliberada de uno mismo se considera como un asesinato, aun cuando se trate de uno mismo. Se es un asesino y víctima al mismo tiempo. Bajo esta lógica, el cristianismo se obstina por defender la propia vida, arguyendo que el hombre tiene la obligación de conservarla para no ofender a Dios y salvar nuestras almas para entrar al otro mundo.

Uno de los pensadores más representativos de la Iglesia, y quien propuso inicialmente la lógica anterior, fue el filósofo Agustín de Hipona (354-430) mejor conocido como san Agustín. Sin duda, él fue uno de los grandes pensadores del cristianismo y se manifestó en contra del suicidio. A continuación, se presenta un extracto de las palabras del propio san Agustín en su obra La ciudad de Dios:

Si a ninguno de los hombres es lícito matar a otro de propia autoridad, aunque verdaderamente sea culpado, porque ni la ley divina ni la humana nos da facultad de quitarle la vida; sin duda que el que se mata así mismo también es homicida, haciéndose tanto más culpado cuando se dio muerte, cuanta menos razón tuvo para matarse; porque si justamente abominamos de la acción de Judas y la misma verdad condena su deliberación, pues con ahorcarse más acrecentó que satisfizo del crimen de su traición (ya que, desesperado ya de la divina misericordia y pesaroso de su pecado, no dio lugar a arrepentirse y hacer una saludable penitencia), ¿cuánto más debe abstenerse de quitarse la vida el que con muerte tan infeliz nada tiene en sí que castigar? Y en esto hay notable diferencia, porque Judas, cuando se dio muerte, la dio a un hombre malvado, y, con todo, acabó esta vida no sólo culpando en la muerte del Redentor, sino en la suya propia, pues, aunque se mató por un pecado suyo, en su muerte hizo otro pecado (1988, XVII, p. 19).

3 Aquí se hace referencia exclusivamente a los textos sagrados u oficiales del cristianismo y no a lo dicho a partir de las interpretaciones posteriores que condenan el suicidio, como si estos provinieran del discurso religioso. Por ejemplo, como ocurre en La Divina Comedia de Dante Alighieri. 

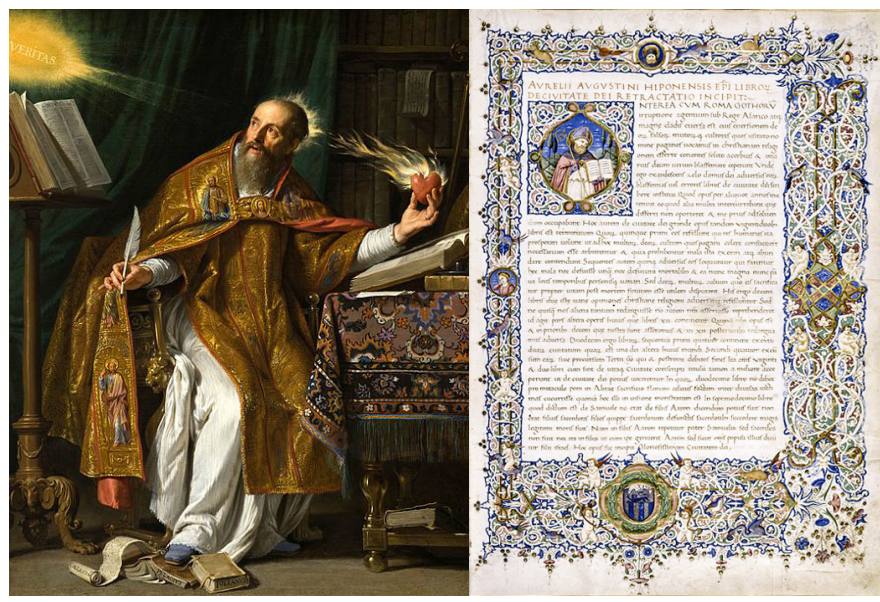

Figura 4. San Agustín de Hipona y su libro La ciudad de Dios.

En realidad, san Agustín expresa estas palabras como forma de consuelo para todos los cristianos angustiados de aquellos tiempos, ya que a finales del siglo IV y principios del siglo V Roma fue amenazada y saqueada en varias ocasiones ${ }^{4}$. Estos saqueos, que acontecieron de forma violenta, orillaron a la gran mayoría de las mujeres al suicidio ya que querían impedir ser torturadas y violadas. Sin embargo, suicidarse por estas razones no tenía ninguna justificación. No se les reconocía el suicidio como medio para evitar un mal como este o alguno semejante. Ni siquiera por la amenaza de enemigos, deshonras o sufrimientos en el cuerpo.

¿Por qué esto era así? No debemos olvidar que, desde el punto de vista del cristianismo, el dolor es algo constitutivo de la existencia del hombre, es decir, si Jesucristo fue torturado y crucificado en la cruz por nosotros los mortales, entonces cualquier acto de violencia a otros o a nosotros mismos estaba justificado, pues no es más dolor que aquel que sufrió en carne propia el hijo enviado de Dios. Además, no hay que olvidar que otro de los mandamientos es "Amarás a Dios con todo tu corazón y con todas tus fuerzas y al prójimo como a ti mismo", por lo tanto, el suicidio sería una ofensa directa a Dios.
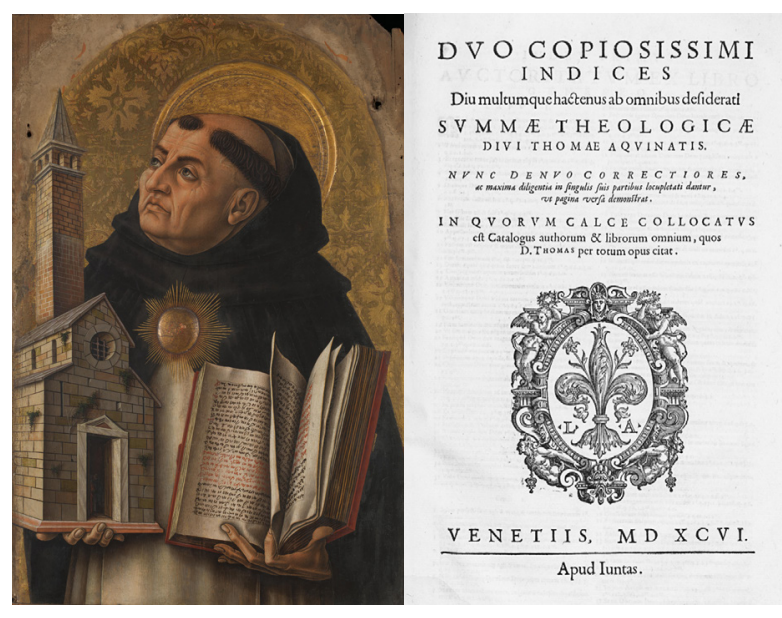

Figura 5. Santo Tomás de Aquino y su obra Suma Teológica.

$4 \quad$ En el año 387 a.C. fue saqueada con violencia por los galos. Años más tarde, en el año 410, ocurrió el saqueo más importante y que causó gran revuelta en la sociedad romana de la época. Estos hechos son considerados por muchos historiadores como momentos claves en el final del Imperio romano de Occidente. 
Santo Tomás de Aquino (1225-1274), otro de los más grandes pensadores de la Iglesia Católica, asume la misma postura que san Agustín y piensa que el suicidio es ir en contra de la ley natural, es decir, ley divina. En su magna obra, Suma Teológica, expresa lo siguiente, apoyado de los textos de Aristóteles:

Es absolutamente ilícito suicidarse por tres razones: primera, porque todo ser se ama naturalmente a sí mismo, y a esto se debe el que todo ser se conserve naturalmente en la existencia y resista, cuanto sea capaz, a lo que podría destruirle. Por tal motivo, el que alguien se dé muerte va contra la inclinación natural y contra la caridad por la que uno debe amarse a sí mismo; de ahí que el suicidarse sea siempre pecado mortal por ir contra la ley natural y contra la caridad. Segunda, porque cada parte, en cuanto tal, pertenece al todo; y un hombre cualquiera es parte de la comunidad como se pone de manifiesto por el Filósofo en el libro V de la Ética a Nicómaco. Tercera, porque la vida es un don divino dado al hombre y sujeto a su divina potestad, que da la muerte y la vida. (1995, pp. 533-534)

Sin embargo, santo Tomás de Aquino hace un ligero cambio respecto a la obra Ética Nicomaquea: el suicidio más que un atentado a la ciudad, como sostiene Aristóteles, es un atentado contra la caridad. Este cambio, que pareciera ser una trivialidad, en realidad es de suma importancia, pues el sentido del acto suicida se transforma cualitativamente. Mientras que, para Aristóteles el suicidio se da como un acto del mismo tipo de naturaleza que cualquier otra acción humana (comer, dormir, etc.), con santo Tomás está orientado a una finalidad trascendental ya que, la caridad forma parte de la naturaleza divina de Dios hacia nosotros.

En resumen, san Agustín como santo Tomás rechazan toda forma de autodestrucción del ser humano que sea fiel a la religión cristiana. Es suficiente mostrar el pensamiento de estos representantes de la Iglesia de aquella época para darse cuenta de las razones por las que el cristianismo (y la mayoría de las religiones tales como el judaísmo y el islam) escarmienta el suicidio ${ }^{5}$.

Ahora bien, queda claro que el suicidio se concibe como un pecado, ¿pero qué explicación ofrece el cristianismo para este tipo de actos? En general, toda la sociedad europea medieval estaba sujeta por el pensamiento de la Iglesia, por lo que cualquier explicación de la naturaleza estaba vinculada necesariamente a Dios. En el caso de las conductas desviadas o atípicas, siempre eran interpretadas desde el marco teológico. Por ejemplo, lo que hoy conocemos como epilepsia era interpretado como posesiones por demonios, los actos de los asesinos como acciones de siervos de satanás, las obsesiones sexuales de los hombres eran producidas por brujas, etc. (Szasz, 2002b). Si un individuo mostraba intenciones de suicidarse, entonces se creía que estaba poseído por algún espíritu maligno, o sea, el suicida tenía un alma o espíritu perturbado que provocaba se diera muerte a sí mismo.

La disciplina encargada para identificar estas conductas anómalas y su tratamiento adecuado era la demonología, que tenía por objetivo el estudio de la naturaleza de los demonios. A partir de la demonología se dio origen a

$5 \quad$ Uno de los casos excepcionales es la religión Jainista que mantiene un rechazo total a todo tipo de afecto y promueve el suicidio por hambre. De hecho, se promueve la nula participación o el actuar tan poco sea posible. Los Jainas tienen un estilo de vida monástico y en extremo austero. 
la dicotomía de comportamiento normal y anormal, algo que heredaría más tarde a la medicina, especialmente a la psiquiatría moderna.

Como la demonología era la disciplina encargada de explicar todas las conductas desadaptadas durante la Edad Media, los clérigos eran los responsables de su tratamiento y su solución. ¿Cómo resolvían el problema? El tratamiento o cura se efectuaba a través de castigos físicos y tortura para expulsión de estos espíritus demoniacos. Incluso en tiempos cercanos a la modernidad, los individuos que eran poseídos por demonios son "sanados" mediante crueles exorcismos.

Todos aquellos que cometían suicidio eran considerados como víctimas de las fechorías de estos demonios, pues las personas carecían de un vínculo hacia Dios haciéndolos más vulnerable a estos ataques, entre otras cosas. Sin embargo, a finales del siglo XVI y principios del XVII, se empezaron a abandonar las explicaciones acerca de las supuestas posesiones demoniacas por aquellas interpretaciones de conductas anormales que se centraban en causas biológicas.

\section{Periodo Moderno}

El primer gran golpe al pensamiento cristiano, y que daría entrada al periodo moderno, llegaría con las ideas racionalistas de René Descartes ${ }^{6}$ (1596-1650). Sus revolucionarias obras, tales como El discurso del método y Meditaciones metafísicas, abrieron una brecha para el surgimiento de la modernidad y, con ello, el nacimiento de diversas ideas actuales en diferentes sistemas de pensamiento. A partir del pensamiento cartesiano varios intelectuales desarrollaron sus trabajos, como el empirista inglés John Locke (1632-1704) y su obra Ensayo sobre el entendimiento humano, o el ilustre filósofo escocés David Hume (1711-1776) y su Tratado de la naturaleza humana.

Este último, David Hume, argumentó en su obra Del suicidio. De la inmortalidad del alma una serie de razonamientos para justificar de manera magistral el suicidio desde el pensamiento cristiano con base en los propios supuestos teológicos. El filósofo sostiene que el suicidio es un asunto del que no se puede derivar una visión negativa, pues todo lo que hagamos es una extensión de las mismas leyes a las que se somete todo lo creado por el todopoderoso. No hay violación alguna si cometemos suicidio porque somos creación de Dios al igual que sus leyes divinas.

Para probar que el suicidio no es transgresión alguna de nuestro deber con Dios, las siguientes consideraciones pueden bastar quizá. Para gobernar el mundo material, el creador Todopoderoso ha establecido leyes generales e inmutables por las cuales todos los cuerpos, desde el planeta más grande hasta la partícula más pequeña de materia, se mantienen en su propia esfera y función. Para gobernar el mundo animal, ha dotado a todas las criaturas vivientes de poderes corporales y mentales; de sentidos, pasiones, apetitos, memoria y juicio, por las que son guiadas o reguladas en el curso de la vida al cual están destinadas. Estos dos principios distintos del mundo material y animal traspasan

6 Sin duda, René Descartes es un héroe del pensamiento a pesar de las posibles contradicciones en su sistema filosófico. Por ejemplo, se declaró como un fiel creyente de Dios y al mismo tiempo es el primero en elaborar, de manera indirecta, una filosofía que sería contraproducente al pensamiento cristiano. 
continuamente los límites del otro y repasan mutuamente la operación del otro. Los poderes de los hombres y de todos los otros animales están restringidos y dirigidos por la naturaleza y las cualidades de los cuerpos que los rodean; las modificaciones y acciones de esos cuerpos son incesantemente alteradas por la operación de todos los animales. (Hume, 2002, p. 180)

Más adelante agrega:

La providencia de la Deidad no aparece de inmediato en cualquier operación, sino que gobierna todo por esas leyes generales e inmutables, que han sido establecidas desde el principio de los tiempos. Todos los acontecimientos, en un sentido pueden declarase acción del Todopoderoso; todos ellos proceden de aquellos poderes con los que él dotó a sus criaturas. Una casa cae por su propio peso no se convierte en ruinas por su providencia más que una destruida por las manos del hombre; las facultades humanas no son creación suya que las leyes del movimiento y la gravitación. Cuando las pasiones actúan, cuando el juicio dicta, cuando los miembros del cuerpo obedecen; todo esto es la operación de Dios, y sobre estos principios animados, así como sobre los inanimados, ha establecido él el gobierno del universo. [...] Puesto que, por lo tanto, las vidas de los hombres son eternamente dependientes de las leyes generales de la materia y el movimiento ¿es criminal que un hombre disponga de su vida porque, en todo caso, es criminal traspasar los límites de estas leyes o perturbar su operación? Pero esto parece absurdo; todos los animales están confiados a su propia prudencia y habilidad para conducirse en el mundo y tienen total autoridad, hasta donde se extiende su poder, para alterar todas las operaciones de la naturaleza. (Hume, 2002, pp. 181-182)

De acuerdo con Hume, si conservamos la vida propia o decidimos acabar con ella es algo que únicamente nos incumbe a cada uno de nosotros, sin que esto pudiera ser una ofensa a Dios. Entonces, el suicidio no es de ninguna manera un pecado, dicha acción puede estar libre de cualquier culpa.
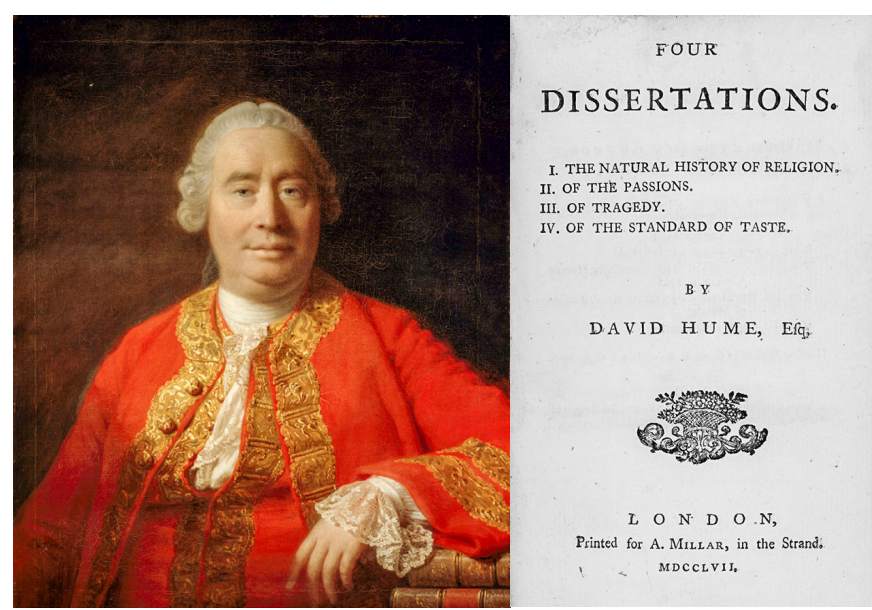

Figura 6. David Hume y su texto Del suicidio. De la inmortalidad del alma. 
Ya adentrados en el siglo XVIII, todas aquellas personas con antecedentes de intentos de suicidio eran enviadas lejos de la sociedad, pues se creía que podían ser un peligro al tratar de imitarse entre la población. Más tarde, se optó por recluirlos en cárceles junto a verdaderos criminales porque al suicidio se catalogó e igualó como un acto delictivo. Este importante cambio significó que las personas suicidas dejaran de ser pecadores para pasar a ser criminales. Lo que antes era un encargo de la Iglesia, ahora era delegada al área jurídica y legal.

Ya en este contexto, el filósofo y político francés Montesquieu (1689-1755) realizó una crítica a las leyes jurídicas que castigaban el suicidio. Montesquieu supuso que algunas de las causas que se consideraban producían el suicidio se encontraban la muerte voluntaria y los desórdenes físicos corporales, y no necesariamente eran precedidos por la locura o aspectos mentales. Por esta razón, propuso que el suicidio fuera tratado no únicamente como una terrible consecuencia de demencia o locura, sino más bien, debería de ser atendido como un problema con sus propias características complejas. En su libro Del espíritu de las leyes menciona lo siguiente:

No vemos, en los historiadores, que los romanos se diesen muerte sin motivo, pero los ingleses se matan sin que se pueda concebir ninguna razón que los determine a ello; se matan hasta en el goce de la felicidad. Ese proceder, entre los romanos, era efecto de la educación, obedecía a su manera de pensar y a sus costumbres: entre los ingleses es efecto de una enfermedad que se debe al estado físico de la máquina corporal, siendo independiente de cualquier otra causa.

Parece ser un desarreglo de filtración del jugo nervioso; la máquina corporal, encontrándose todas las fuerzas motrices sin acción, se cansa de sí misma; el alma no experimenta dolor, sino cierta dificultad para existir. El dolor es un mal local que nos incita a desear que se acabe, el peso de la vida es un mal que no radica en ningún sitio concreto y que lleva al deseo de concluir esta vida.

Es evidente que las leyes civiles de algunos países han tenido razones para condenar el suicidio, pero en Inglaterra no puede castigárselo más de lo que se castigan los efectos de la demencia (Montesquieu, 2002, p. 334).

Dado que asumía que era amplio el espectro causal del suicidio, consideró que no debería de ser susceptible de castigarse legalmente en todos los casos.
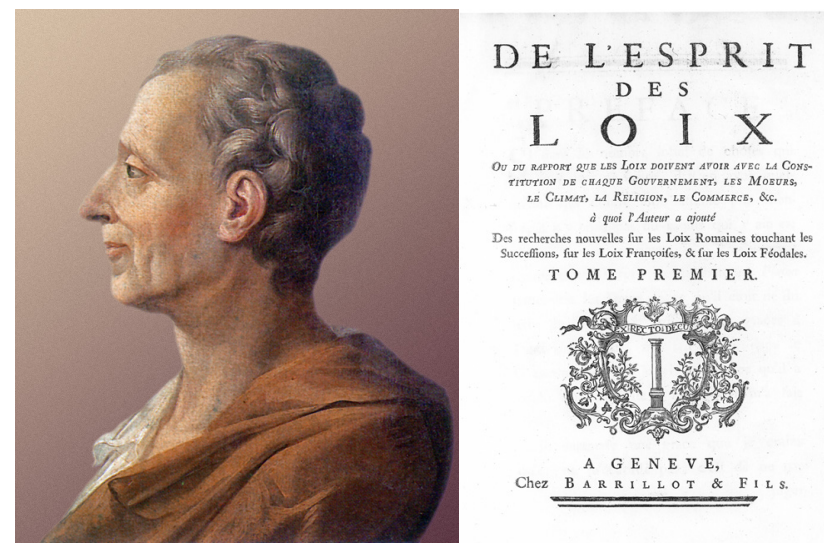

Figura 7. Montesquieu y su obra

Del espíritu de las leyes. 
Por otro lado, desde una literatura pesimista, sobresale el filósofo alemán Arthur Schopenhauer (1788-1860) por ser uno de los escritores que expresó mucho acerca del suicidio, la vida, la muerte y el dolor. Este filósofo concibe al suicidio como una manifestación de plena libertad del individuo que se lleva a cabo con un verdadero sentido de la vida, pues es una forma de detener el sufrimiento y dolor. Schopenhauer nos dice que la persona que se suicida es la que mejor entiende el significado de la vida y su forma de expresión, por eso rechaza todo aquello que atente contra ella. En su obra El mundo como voluntad y representación menciona lo siguiente:

El suicidio, lejos de negar la voluntad de vivir, la afirma enérgicamente. Pues la negación no consiste en aborrecer el dolor, sino los goces de la vida. El suicida ama la vida; lo único que le pasa es que no acepta las condiciones en que se le ofrece. Al destruir su cuerpo no renuncia a la voluntad de vivir, sino a la vida. Quiere vivir, aceptaría una vida sin sufrimientos y la afirmación de su cuerpo, pero sufre indeciblemente porque las circunstancias no le permiten gozar de la vida. La voluntad de vivir se encuentra tan cohibida en el fenómeno de su individuo aislado, que no puede desplegar su vuelo.

(Schopenhauer, 2013, p. 394)
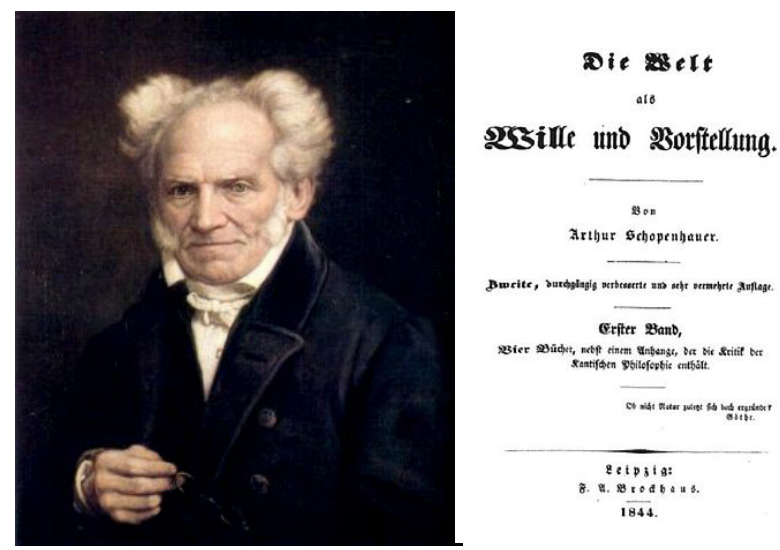

Figura 8. Schopenhauer y el libro

El mundo como voluntad y representación.

Aquel que se suicida hace un doble "movimiento", con su acto: opta por morir, al mismo tiempo que aprecia y valora la vida. Se comete suicidio porque se reconoce el valor de vivir, porque se comprende que no se consiguió, por cualquier razón que sea esta, hacerlo de la mejor manera. Visto así, el suicidio podría considerarse como un acto de rebeldía intelectual y emocional extrema. De acuerdo con Schopenhauer, sería el acto más sublime del querer del ser humano, un acto de total sumisión a la voluntad de vivir, nunca su negación.

Para mediados del siglo XIX surgiría una de las teorías científicas más revolucionarias de la historia y que de manera inadvertida colocaría al suicidio como un acto que se opone a la lógica de la naturaleza de los seres vivos: la Teoría de la Evolución, de Charles Darwin (1809-1882). En 1859, Darwin publicó su obra El origen de las especies y cambió la visión que tenemos acerca de nosotros mismos y del resto de las especies de nuestro planeta. En dicha obra, sostiene la siguiente tesis principal apoyada con evidencia empírica: la evolución es el proceso por el cual la vida se ha desarrollado y consiste en los cambios paulatinos y adaptativos que sufren los organismos para sobrevivir. Los que estén mejor adaptados al medio tienen mayores probabilidades de reproducción y supervivencia, es decir, cada organismo en cada especie compite para poder acceder a los recursos necesarios. 

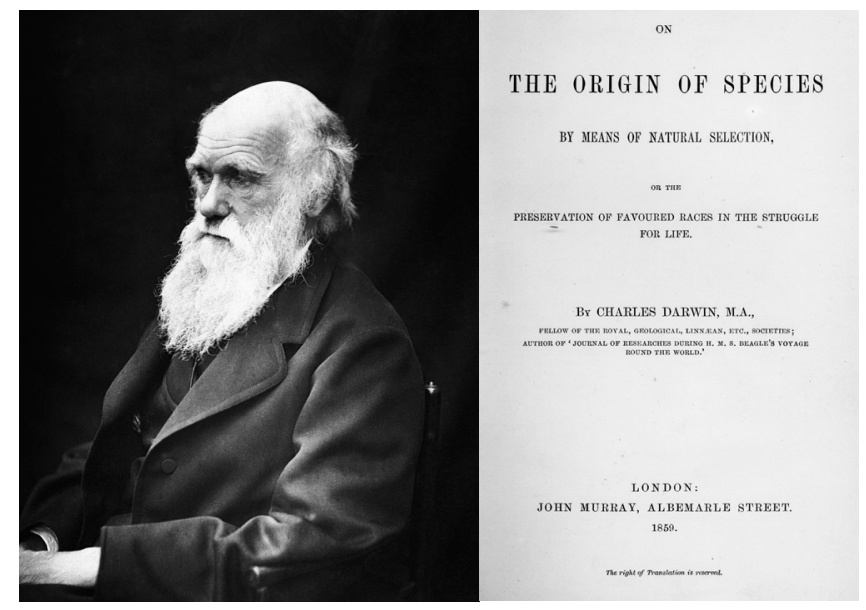

Figura 9. Charles Darwin y su libro El Origen de las Especies.

¿Cómo ocurren estos cambios evolutivos? La evolución está mediada por algo que se llama "selección natural" y que consiste en la presión selectiva de los organismos a determinados ambiente para la sobrevivencia. Este proceso se puede confirmar con base en los miles de fósiles que se han descubierto. Por ejemplo, Darwin observó a partir de diversos registros fósiles que era posible ver detalladamente que los picos de los pájaros pinzones han cambiado a lo largo del tiempo, en ambientes muy particulares, y que estos cambios les ayudaron a sobrevivir.

Con evidencias de este tipo es posible comprender cómo estructuras simples a través de millones de años acabaron evolucionando en criaturas complejas, incluyendo por supuesto al ser humano.

Darwin había comprendido que los animales compiten para su supervivencia y en esa lucha por la existencia se presentaban algunos cambios en aquellos que lo lograban, pues transmitían sus cualidades a sus descendientes. Al respecto, menciona lo siguiente en su principal obra:

A fin de explicar cómo obra, según creo, la selección natural pediré permiso para dar uno o dos ejemplos imaginarios. Tomemos el caso de un lobo que se ceba en varios animales, alcanzando algunos por la astucia, otros por la fuerza y otros por la velocidad; número por algún cambio en el país, o que hubiera decrecido otra especie durante la estación del año y supongamos que su presa más ligera, un gamo, por ejemplo, hubiera aumentado en que el lobo estaba más apremiado por la necesidad de comida. Bajo tales circunstancias los lobos más delgados tendrían las mejores posibilidades de sobrevivir y así ser preservados o seleccionados, siempre que conservasen bastante robustez para dominar a su presa en este $u$ otro periodo del año en que se vieran obligados a cazar otros animales (Darwin, 2011, p. 73).

Así, la teoría de la evolución describe el proceso de cómo todos los seres vivos llegamos hasta aquí y en la forma actual. Nosotros los humanos, así como el resto de los animales, somos producto de la evolución y no por un diseñador divino.

Esta competencia por la supervivencia en todos los seres vivos ha derivado de forma implícita en la idea de que la vida es lo más importante, sin importar la especie, género y complejidad del organismo. ¿Por qué? Porque 
parece ser inherente a la naturaleza, pues es posible observarla en cada una de las especies. Incluso las acciones reflejas más simples parecen ir encaminadas a la protección y adaptación al medio para la supervivencia.

Con base en esta teoría, es claro que el suicidio va en contra de la supervivencia. Cualquier conducta orientada a la autodestrucción se opone a un impulso biológico primario de los seres vivientes. Esta naturaleza innata o refleja de los organismos para actuar siempre en favor de la vida no da lugar a un comportamiento suicida en el proceso de la evolución.

No obstante, es necesario que mencione el curioso caso del "comportamiento suicida" de las abejas cuando se trata de defender el panal. La defensa consiste en aguijonear a cualquier depredador o enemigo que intente alterar la organización del panal. Al hacer esta acción muere la abeja, pues el aguijón no es retráctil por lo que al sacarlo ocasiona que se desprenda del abdomen con parte de su sistema digestivo. Esta acción pareciera como si las abejas dieran su vida por defender el panal'.

No es el propósito explicar el suicidio en términos de la biología, más bien interesa mostrar que esta teoría científica al explicar la evolución de los seres vivos (humanos, animales, plantas y microorganismos) ejerció una gran influencia de forma indirecta en la valoración social del suicidio, en especial en la psicología con importantes implicaciones como veremos más adelante.

Por otro lado, y desde la sociología, el francés Emile Durkheim (1858-1917) conceptualizó al suicidio como un fenómeno sociológico y no como uno puramente individual. En su obra El Suicidio, menciona que todo acto suicida es resultado de perturbaciones de dependencia con la sociedad y, por consiguiente, se trata en principio de un evento social. Esta es una de sus grandes aportaciones conceptuales: comprender que en el suicidio existen algunos factores determinantes que no son necesariamente de origen clínico o psicológico, por el contrario, el suicidio es un acto individual y único, pero su naturaleza siempre de índole social.

En efecto, si en lugar de no ver en ellos más que acontecimientos particulares, aislados, que deben de ser examinados por separado, consideramos el conjunto de los suicidios cometidos en una sociedad dada, durante una unidad de tiempo determinada, comprobaremos que el total no es una simple suma de unidades independientes ni una colección, sino que constituye por sí mismo un hecho nuevo y sui generis, con su propia unidad e individualidad, es decir, con naturaleza propia, una naturaleza eminentemente social. (Durkheim, 2012, p. 15)

Así, el suicidio se expresa de muchas formas por causas sociales, particularmente cuando la sociedad no les brinda o proporciona a sus miembros los recursos necesarios para establecer los vínculos interpersonales adecuados.

$7 \quad$ Más adelante ahondaré acerca de la imposibilidad de identificar auténticos actos suicidas en los animales. Por ahora, solamente diré que los animales no tienen la capacidad de suicidarse y esto se debe a la falta de lenguaje convencional que posibilita la conciencia de la finitud y muerte de ellos mismos. La comunicación animal no tiene entre sus características el establecimiento de un comportamiento lingüístico que les permita "saber" que van a morir. Si esto es correcto, entonces no pueden pensar en aniquilarse a sí mismos. 
Por ejemplo, podría ser que las adicciones a las drogas que propician la autodestrucción en los jóvenes sean una consecuencia de la fractura en las relaciones de los grupos sociales, especialmente en el núcleo familiar. Durkheim elaboró una clasificación en la que distingue cuatro tipos de suicidios:

- Suicidio egoísta. Se presenta cuando la persona se siente enojada con la sociedad y tiene pocos lazos. La persona se caracteriza por la carencia de integración social. Un ejemplo serían las personas solitarias o ermitañas que al no establecer vínculos afectivos con persona alguna optan por suicidarse.

- Suicidio anómico. Se refiere a la actividad "alterada" del individuo en su vida diaria, es decir, que sufre la falta de normas que lo vinculan a la sociedad. Ocurre en aquellas personas que experimentan situaciones de crisis provocadas por un desajuste social o como eventos que se presentan fuera de los márgenes de la cotidianidad. Por ejemplo, cuando una persona le decomisan su casa de forma injustificada por parte del banco o cuando no tiene un empleo que le permita tener acceso al mercado de consumo y vivir con las condiciones mínimas necesarias.

- Suicidio altruista. Este tipo de suicida es característico de personas que se desenvuelven en comunidades con alto grado de integración social. El individuo al estar excesivamente unificado a su comunidad se suicida por ella sin que le importe perder su identidad. Ejemplos de este tipo de suicidio son los pilotos japoneses kamikaze o aquellos soldados patriotas que prefieren morir por su país antes que traicionarlo. Otro caso es cuando una persona sacrifica su vida (comúnmente es reconocido como "héroe") por la vida de alguien más.

- Suicidio fatalista. Se presenta cuando las reglas (morales, religiosas, económicas, etc.) a las que está sometido el individuo son demasiadas crueles como para que éste abandone la situación en la que se encuentra. Generalmente, se presenta cuando las personas consideran que su situación es inmutable y son incapaces de poder cambiar o influir en ella. Es una condición parecida a la esclavitud. Por ejemplo, los suicidios de obreros que son explotados en su jornada laboral.

A esta tipología de suicidios se le puede considerar como el ejemplar pionero que dio origen a las clasificaciones contemporáneas de los más diversos comportamientos en la psicología, psiquiatría y otras disciplinas de la salud.

Durkheim, con base en sus estudios y su clasificación de suicidios, describe y explica las diversas causas externas a los individuos, tales como los factores económicos, de clima, geografía, la participación de instituciones religiosas y políticas etc., que pueden propiciar, o no, que las personas terminen con su vida. Es importante recalcar que estos factores "externos" al individuo se consideran como cuestiones sociales más que propias de la individualidad de la persona suicida.

Por último, habría que decir que, de acuerdo con este sociólogo, una solución que podría favorecer la integración entre el individuo y su sociedad es la profesión, oficio o trabajo satisfactorio para quien lo desempeña. Durkheim considera que una actividad laboral placentera puede promover el éxito personal y generar el sentido de permanencia en la sociedad. 


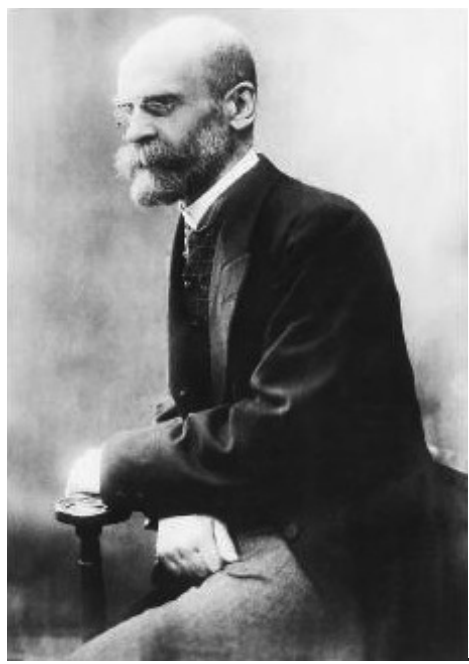

\section{SUICIDE}

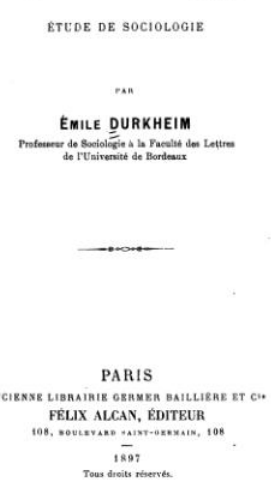

Figura 10. Emile Durkheim y su libro El Suicidio.

En la segunda mitad del siglo XX, después de las atrocidades que trajo consigo la Primera y Segunda Guerra Mundial, surgieron diversas líneas de pensamiento que tenían por objetivo replantear la conceptualización del ser humano y su papel en la construcción del mundo. La línea filosófica existencialista tuvo una gran aceptación por sus ideas de libertad y responsabilidad del ser humano en cada uno de sus actos, así como eliminar todo tipo de excusas.

Desde la literatura existencialista, el extraordinario escritor francés Albert Camus (1913-1960) plantea en su obra El mito de Sísifo la filosofía del absurdo como una forma de interpretar lo insignificante de la vida y el valor que tiene para cada uno de nosotros en función de lo que queramos atribuirle. Esta obra es parte de la mitología griega y relata que el héroe griego hace enfadar a los dioses por desafiarlos. Esta acción retadora provocó que los dioses lo condenaran a perder la vista y cumplir la tarea de empujar una gigantesca roca hasta la cima de una montaña para que después la roca regrese rodando cuesta abajo hasta el punto de inicio. Sísifo debía empujarla nuevamente así por la eternidad de los tiempos. Camus retoma este mito para discutir el tema del suicidio como una metáfora de lo que parece ser un esfuerzo inútil de manera continua en cada persona como, por ejemplo, las labores de los obreros y empleados que trabajan durante todos los días de su vida haciendo las mismas tareas hasta el final.

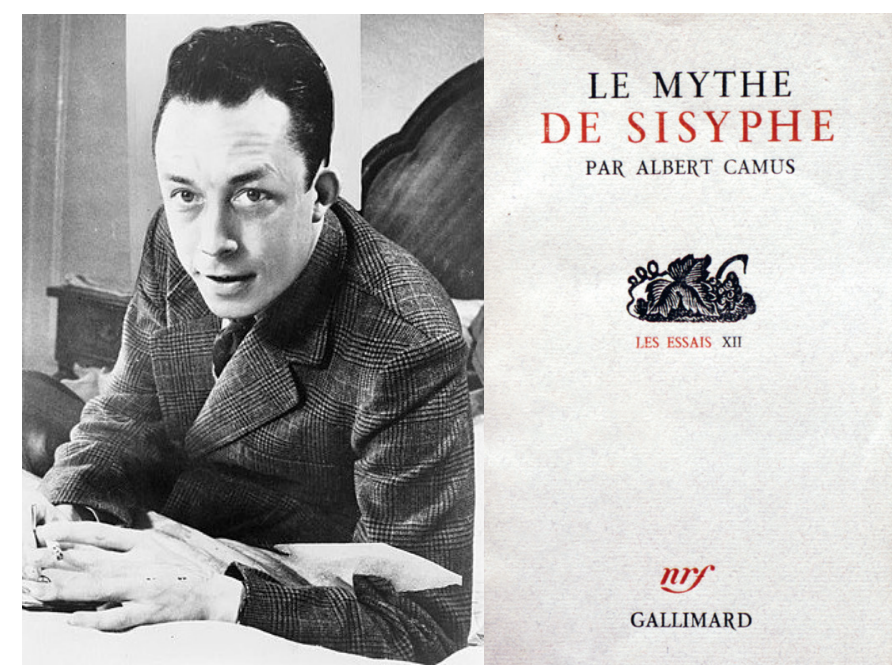

Figura 11. Albert Camus y su obra El mito de Sísifo. 
La condición miserable que vive Sísifo se puede equiparar al suicidio ya que su vida y su existencia se vuelven absurdas. Sin embargo, Camus asegura que cuando Sísifo reconoce la insignificancia de su tarea y la certeza de su destino, es "liberado" para darse cuenta de lo absurdo de su situación y para conseguir a un estado de aceptación. El hombre, sostiene Camus, debe aceptar su estado y nunca evadir la realidad, por eso, el suicidio siempre debe ser la última salida.

\section{El suicidio en el siglo XXI}

En la época actual, nuestras acciones tienen una mayor importancia en el plano legal y de la salud. Todo aquello que no se encuentre dentro de los límites legales y criterios de salud es valorado como delito y enfermedad, respectivamente. En lo que compete al suicidio, se le ha considerado desde hace ya bastantes décadas como un problema de salud pública, pues la concepción actual que se tiene al respecto dentro de la psicología y psiquiatría es conocida ampliamente por todos: el suicidio se trata de una enfermedad mental o un comportamiento anormal que va en contra de la salud y bienestar (Szasz, 1989; Organización Mundial de la Salud, 2007).

Desde una perspectiva histórica, es evidente que la valoración actual del suicidio es consecuencia directa de diversas transformaciones sociales que le anteceden. Pero, ¿qué condiciones actuales mantienen esta visión del suicidio?, ¿por qué se le considera como un problema de salud pública?, ¿por qué el encargo social de la psicología en el ámbito de la salud es la prevención y tratamiento del suicidio?, ¿son alarmantes los casos de suicidio?, y si lo son ¿en qué sentido y por qué?

Un buen punto de partida para responder estas preguntas es la definición que ofrece el principal organismo internacional responsable de la salud, la Organización Mundial de la Salud (OMS). Esta autoridad directiva y coordinadora de acción sanitaria internacional es la encargada de desempeñar una función de liderazgo en los asuntos de salud mundial, mediante el establecimiento de normas y políticas de apoyo especializado a los países.

¿Qué entiende la OMS por salud mental? De acuerdo con este organismo, la salud mental no es sólo la ausencia de trastornos mentales, sino al estado de bienestar, en el cual el individuo es consciente de sus propias capacidades y puede afrontar las tensiones normales de la vida. Una condición como ésta permite el trabajo de forma productiva y fructífera, de tal manera que la persona sea capaz de hacer una contribución a su comunidad.

Si bien, es cierto que para la OMS las enfermedades mentales (en especial la depresión) y los diversos entornos culturales y sociales constituyen importantes factores de riesgo de suicidio, siempre se refiere a este último como un trastorno mental. Esta concepción del suicidio está amparada en el modelo médico de la salud-enfermedad, por tanto, es considerada como cualquier otra enfermedad, como la gripe, el cáncer, la diabetes, etc., y debe de atenderse como tal (OMS, 2018).

Esta visión del suicidio, como una problemática en el marco de la salud, es equivocada. En realidad, se trata de un falso problema que se formula con otros fines. Las diversas instituciones gubernamentales y de la salud nos han hecho creer que el suicidio es un problema por razones que no son del todo ciertas. En el fondo, tiene que ver con el control de los individuos en la sociedad y con las pérdidas económicas que les genera a los países. La visión trágica del suicidio y su prevención no es únicamente resultado de un sentido humanitario de parte estas instituciones. 
Empezaré por hablar del control de los individuos en la sociedad. Todas las instituciones sociales tienen entren sus diferentes funciones, ya sea que lo expliciten o no, mantener cierto orden social, a través del control de los individuos que conforman una comunidad. Por ejemplo, la institución religiosa controla nuestro comportamiento en distintas etapas de nuestra vida. Desde el nacimiento (mediante el bautismo) hasta la muerte (por medio del entierro en "tierra santa"). A través del matrimonio norma ciertas conductas para la convivencia en pareja, y proporciona las reglas de cómo se debe de vivir en general.

En el ámbito empresarial, el control va desde cosas tan superficiales como los requerimientos de vestimenta formales y específicos que son característicos, hasta la gestión de la vida propia bajo la misma lógica laboral (por ejemplo, las relaciones amorosas practicadas como un intercambio económico y material).

Todas las instituciones promueven de maneras muy sutiles la incorporación de valores y formas de pensamiento típicas del mercado de consumo a nuestra vida diaria. Las instituciones de salud no escapan de la influencia y lógica del capitalismo actual. La mayoría de la gente cree que los asuntos de salud son independientes de cualquier forma actual de pensamiento consumista del mercado. Sin embargo, todo criterio de "salud universal" es regulado e impuesto desde "afuera", estableciendo un determinado orden en la sociedad. En el tema que nos interesa, la prevención de los suicidios es una forma de ejercer un control para mantener el orden.

Ahora bien, es posible que el lector quiera contra cuestionar lo que he dicho mediante las siguientes preguntas: ¿acaso no hay una preocupación natural en las personas por prevenir el suicidio sin que esté ligado necesariamente al pensamiento consumista capitalista? Supongamos que no lo haya, ¿qué tiene de malo mantener el control en la sociedad para prevenir los suicidios? ¿evitar los suicidios no es algo que cualquier ser humano querría? O en todo caso, si es cierto lo que afirmo ¿qué posible interés "malévolo" podría existir detrás de la idea del suicidio como un problema de salud?

Respecto a esta última pregunta, el interés proviene de un grupo de personas que necesitan que el suicidio sea visto de esta manera para sus propios beneficios. Es decir, la gente que maneja la riqueza económica y ejerce el poder político en el mundo a su conveniencia. Ellos, los empresarios y líderes mundiales, son quienes toman decisiones, son los más interesados y preocupados en naturalizar la idea del suicido como un problema de salud.

Es posible que el lector discrepe de lo anterior y sostenga que no es necesario que una persona tenga un poder político semejante a la de un empresario o tener la riqueza típica de la aristocracia para que muestre un interés e intenciones genuinas por prevenir el suicidio de cualquier persona. Sin embargo, no hay que olvidar que aquello que sentimos y pensamos en nuestra "más íntima subjetividad" no está del todo desligado de la ideología vigente y que promueven de forma directa o indirecta las diversas instituciones sociales. La supuesta naturaleza innata del ser humano por evitar el suicidio no es tal, aun cuando pareciera ser así por el hecho de sentirlo en nuestros adentros.

Claro, hay personas con genuinas intenciones y de sentimientos nobles que experimentan esa sensación de auxilio por aquella persona que pretende suicidarse, por ejemplo, cuando una madre que desea evitar el suicidio de su hijo. Uno podría pensar que tal sentimiento que experimenta una madre en tal situación va más allá de aquello que puedan promover las instituciones sociales. Pero, esto no es así, incluso bajo el argumento biológico de la conservación de la especie que es posible observar en distintos animales. 
Diferentes organizaciones se encargan de instaurar prácticas orientadas al fortalecimiento de relaciones familiares, tales como las religiones y de salud. Si no fuera así, no tendrían lugar todos los filicidios que se comenten en el mundo. Ni siquiera en los animales se puede hablar de excepciones, pues en condiciones extraordinarias las madres se comen a sus propias crías para su supervivencia.

Ahora bien, el control del suicidio en los individuos está ligado a un aspecto económico. El suicidio, y su prevención, se relaciona de una forma particular con la economía actual: hay un costo económico por los suicidios que casi nunca se hace mención en los múltiples discursos de prevención del suicidio. El interés de los gobiernos por prevenir los suicidios no surge de una mera cuestión de salud y percepción de bienestar de los individuos que conforman la sociedad. Lo que nunca mencionan es que los intentos de suicidio y los suicidios consumados constituyen una importante carga económica para los estados de cualquier nación y, por eso, les ocupa frenar a todas las personas que intenten hacerlo. Las Naciones Unidas dan cuenta de esto:

Además del coste económico relacionado con la provisión de diversos servicios sanitarios a aquellos que muestran comportamientos suicidas y para las personas que les rodean, existe también el hecho de que estos individuos no suelen seguir contribuyendo al funcionamiento social y económico de su comunidad. Una medida de esto es el cálculo de los años de vida productiva perdidos. Se estima que, a nivel global, la pérdida económica debida a los comportamientos suicidas alcanza aproximadamente el 2,5\% de la carga económica total debida a las enfermedades. (1996, p. 14)

Muy debajo de toda preocupación por la salud existe un interés económico. El sistema capitalista en el que nos desenvolvemos trae consigo criterios económicos y morales que asocian inevitablemente a las personas con la producción y generación de riqueza. El modelo actual de mercado se encarga de formar personas productivas en términos de consumo, por lo que son importantes en tanto puedan brindar su fuerza de trabajo para el sistema. Si las personas empiezan a suicidarse, sobre todo si se trata de jóvenes, el sistema no podrá funcionar correctamente.

Con lo dicho hasta ahorita, no pretendo insinuar que en cada ocasión que visitamos al médico, psicólogo, psiquíatra u otro especialista en la salud, nos engañen porque en el fondo saben que si nos suicidamos perjudicamos al sistema y eso es algo que no le conviene a nadie. Tampoco estoy sugiriendo ir hasta el otro extremo y cometer suicidio por cualquier cosa para liberarnos de todo condicionante del sistema. Simplemente, proporciono el contexto que constantemente permea y moldea nuestra visión del suicidio.

Ahora bien, retomando nuestro recorrido histórico, el suicidio que había sido considerado como una manifestación criminal, ahora es valorado como una enfermedad mental. Pasó del plano legal al plano de salud. Este cambio es el responsable de que diversas disciplinas, como la psiquiatría y la psicología, comenzaran a involucrarse en el problema. Como menciona Szasz (2002a):

La trasformación del autoasesinato de acto deliberado a consecuencia no buscada de una enfermedad (de la mente o el cerebro) constituye el origen de la seudociencia de la psiquiatría y de las enormemente influyentes instituciones de control que se apoyan en sus afirmaciones, llamadas "teorías", o 
en su coerción, llamada "tratamiento". La "conversión del suicidio en locura" (insanitizing) precede al nacimiento de la psiquiatría. Esta es el resultado, no la causa, de la trasformación del autoasesinato de "pecado y crimen" en "enfermedad como disculpa". (p. 71)

La enfermedad que padece el suicida es, supuestamente, debido a la existencia de un desequilibrio mental. Por lo tanto, la tarea actual de los psicólogos y psiquíatras es encontrar los desperfectos del aparato psíquico o los síntomas patógenos que aparecen en cada suicida para determinar el tratamiento adecuado antes de que cometa suicidio. En este sentido, la prevención del suicidio se establece como la meta principal para todos los especialistas de salud en esta forma de comportamiento.

\section{Conclusiones}

Hay dos puntos que deben quedar claros hasta ahora. Primero, el suicidio es un comportamiento que ha existido en todas las sociedades y su valoración está fuertemente influida por las condiciones sociales particulares que prevalecen en una determinada época. Segundo, la conceptualización y sentido del suicidio en su estado actual sólo puede entenderse con profundidad desde una perspectiva histórica, es decir, a través de la construcción sociohistórica. Con estos dos puntos quiero enfatizar que el cuerpo conceptual y simbólico de los discursos de cada perspectiva obedece a criterios temporales y geográficos que están permeados por la ideología establecida.

En el periodo de la antigua Grecia las concepciones del suicidio eran diversas, sus reflexiones se formulaban con base en criterios racionales y siempre a partir de la observación de las personas en su medio ambiente. A pesar de las diferentes perspectivas, todas ellas se mantuvieron una constante de caracterizar al suicidio como una decisión personal basada en juicios lógicos cuyas consecuencias impactaban directamente en la sociedad.

Con el surgimiento del cristianismo y su establecimiento por toda Europa, el sentido de la vida adquirió un bien divino, por lo tanto, todo aquello que atentará contra ella, como el suicidio, se le concibió como un pecado. El pensamiento acerca del suicidio se volvió uniforme pues todo giraba en torno a las leyes de Dios con implicaciones trascendentales, y secundariamente algunas terrenales. Los intelectuales eclesiásticos elaboraron varios argumentos, en términos dogmáticos, reprobatorios a las personas que intentaban suicidarse y de aquellos que lo lograban. El suicidio se volvió un asunto exclusivo de clérigos y autoridades de la institución religiosa. Su principal forma de afrontar el suicidio era a través de la demonología, disciplina que tenía como propósito luchar contra los demonios que perturbaban el alma de las personas que eran siervos de Dios. La demonología "atendía" a las personas con intentos de suicidio a través castigos corporales y exorcismos.

Sin embargo, en algún momento durante la transición de la Edad Media al Renacimiento, las personas empezaron a desafiar a la autoridad clerical y confiaron cada vez más en la observación y experimentación. Se comenzó a dar una transición en el pensamiento de la sociedad y con ello la transmutación de los pecados a enfermedades mentales (Szasz, 2002a; 2002b). Esto orilló a que las explicaciones de la demonología fueran sustituidas por las concepciones médicas (biológicas) que ahora conocemos como desórdenes mentales.

Más tarde, el suicidio empezó a tener implicaciones legales y pasó a ser un delito del cual el Estado se apropiaría su legitimización por igual en la sociedad. A los suicidas se le equiparó al mismo nivel que los delincuentes, 
como si se tratasen de asesinos, asaltantes y violadores. ¿Por qué eran encerrados a manera de criminales? Porque este comportamiento no se ajustaba a los criterios sociales y morales que se caracterizan por arrastrar ideas de diversas influencias como las que ya se han mencionado.

Es importante entender que, el actual cambio del suicidio como delito a suicidio como locura ha servido de excusa perfecta para enclaustrar en internados a la gente con deseos de morir. Hoy en día, sigue siendo tema de polémica acerca del alcance que tienen las personas para respetar las decisiones de suicidarse.

Actualmente, se apuesta por un punto de vista humanitario en casi todos los discursos, mediante la prevención al suicidio, no obstante, en el fondo se trata de un problema por el control social y de desarrollo económico. El suicidio es considerado como una enfermedad de la mente, y como cualquier otra enfermedad orgánica, que requiere de tratamiento médico y psicológico. Para ser precisos, se cree que el suicidio es un síntoma psiquiátrico. Algunos expertos afirman que actualmente los diferentes sistemas de diagnóstico de la más alta autoridad médica, como el DSM (Diagnostic and Statistical Manual of Mental Disorders) y la CIE (Clasificación Internacional de Enfermedades), no consideran a los suicidas como locos o víctimas de la locura.

Sin embargo, cualquier definición del suicidio en dichos manuales médicos deja de tener relevancia mientras se continúe con las mismas prácticas y tratamientos: a los suicidas se les interna (¿aprisiona?) "por su bien” en hospitales psiquiátricos (¿manicomios?) para curarlos (hacer lo que otros quieren). Sin importar la designación empleada para suavizar los procedimientos coercitivos en los suicidas, mientras no se cambien las prácticas y costumbres, los suicidas serán considerados como locos. Si alguien intenta suicidarse sin obtener éxito, es altamente probable que sea encerrado para que no lo vuelva hacer. Y en su contraparte, si una persona intenta suicidarse y otra logra impedirlo, este último es considerado un héroe.

Todo lo expresado hasta aquí, más que un recuento cronológico del suicidio, muestra la dinámica de las transformaciones sociales que van permeando la noción del mismo. Si se entiende cómo cambian los procesos sociales, entonces es claro que la concepción actual de suicidio como una enfermedad no es resultado de un progreso con base en criterios racionales, como comúnmente se cree (Foucault, 1986). Es decir, se piensa que las concepciones más actuales del suicidio son mejores y más precisas que todas aquellas que se formularon en épocas pasadas. Como si se tratara de un progreso intelectual lineal y acumulativo que nos lleva a conocer la "verdadera" naturaleza del suicidio. Sin embargo, todo el asunto no es más que una construcción de intereses de poder e influencias históricas como la religión cristiana, la teoría de la evolución y la lógica capitalista.

Sin perder vigencia los planteamientos e interrogantes de las diferentes disciplinas que han abordado el tema del suicidio, en nuestros días, la ciencia y la tecnología se levantan como dos modos de saberes que están en la posibilidad de ofrecer respuestas desde un distinto nivel analítico de la realidad. Las grandes civilizaciones del pasado han formulado varias interrogantes y brindado todo tipo de respuestas, pero ninguna satisfactoria. Tal vez porque la mayoría de ellas se ha elaborado con base en la intuición y no mediante la investigación con rigor sistemático. ¿La ciencia y tecnología podrían ofrecernos alguna respuesta? Es muy posible que sí puedan aportar algo para nuestro entendimiento y conocimiento del suicidio. La ciencia psicológica tiene mucho que aportar en este asunto, y es justamente lo que trataré en el siguiente capítulo. 


\section{CAPÍTUlO 2}

\section{Teorías e investigación sobre el suicidio en la psicología contemporánea}

Si un joven muere de aneurisma, no decimos que lo ha hecho para que su familia se sienta culpable.

Pero si se suicida, a veces lo interpretamos así. Como consecuencia, poseemos un repertorio ilimitado de explicaciones para el estudio del suicidio, como atribuirlo al chantaje, al martirio, a una enfermedad mental, a un tratamiento médico, a la autoliberación, etc.

Thomas Szasz

El propósito de este capítulo es mostrar el panorama actual de las teorías psicológicas que se enfocan exclusivamente al fenómeno del suicidio. Describiré sus supuestos básicos, sus metodologías de investigación y las explicaciones que han brindado al respecto. Asimismo, señalaré las limitaciones de cada una de estas teorías. Pero antes de adentrarme, quisiera exponer brevemente el estado actual de la psicología para que se entienda mejor el porqué de la existencia de tantas teorías distintas entre sí acerca del suicidio.

\section{Estado actual de la psicología}

Es común que quienes nos iniciamos en la ciencia psicológica nos encontremos con una amplia gama de teorías, generales y específicas, que se ocupan de abordar diferentes fenómenos psicológicos: aprendizaje, memoria, inteligencia, creatividad, sensación, percepción, emoción, sueños, personalidad, motivación, suicidio, etc. También hallamos un sinfín de conceptos que tienen múltiples significados y que no son compatibles entre las diferentes teorías. Y ni qué decir de la variedad de procedimientos metodológicos en los que se utilizan diferentes aparatologías y distintas métricas para medir, supuestamente, los mismos fenómenos.

Todas las teorías parecen ir acompañadas de conclusiones explicativas que van desde aquellas que sea aproximan a lo esotérico hasta las más artificiales. Este panorama actual de la psicología se puede interpretar de muchas formas, pero quisiera esbozarlo, con fines expositivos, en dos grandes posturas. 
La primera postura concibe a la psicología como una disciplina unificada que es "rica" en teorías de todo tipo que pretenden explicar una extensa gama de fenómenos psicológicos (Bruner, 2007; Matarazzo, 1987), y en algunos casos abarcan fenómenos no psicológicos ${ }^{1}$. Esta es una perspectiva de la psicología vista como una disciplina armoniosa y coherente que permite la vinculación con cualquier campo de conocimiento humano, o sea, trabajo interdisciplinario. Por ejemplo, sociopsicología, neuropsicología, psicobiopolítica, psicoantropología, etc. ${ }^{2}$ La psicología, desde esta postura, está constituida por el pluralismo de ideas en el que todo mundo puede incorporar la disciplina de su interés.

La segunda postura concibe, de manera contraria, a la psicología como una disciplina en la que abunda el eclecticismo teórico. Un sinsentido de disciplina debido al inexistente acuerdo acerca del objeto de estudio. De ser correcto esto, los psicólogos caeríamos en prácticas teóricas erróneas que tendrían como resultado la creación de confusiones y la generación de seudoproblemas. Quienes se adhieren a esta postura sostienen que cuando las diferentes teorías en psicología se proponen estudiar los mismos fenómenos, como la inteligencia, imaginación, depresión, suicidio, etc., en realidad se tratan de diferentes clases de eventos. Simplemente todo es una ilusión del lenguaje y un gran malentendido. No ahondaré demasiado en esta problemática del objeto de estudio de la psicología pues ya lo han hecho otros de manera extensa y precisa (Braunstein, Pasternac, Benedito y Saal, 2008; Ribes, 1982; 1989; 2000; 2013; Roca, 2006; Porras, 2011). Basta decir que cada teoría psicológica parte de diferentes supuestos epistemológicos y ontológicos, por lo tanto, son diferentes concepciones de lo psicológico.

¿Cuál de las dos posturas es correcta o verdadera? Considero, al igual que muchos colegas, que la segunda postura se apega más a la situación actual. La psicología se encuentra en un periodo de proyecto de ciencia en espera de consolidarse, esto quiere decir que está en una etapa en la que aspira a madurar en una teoría coherente que unifique la lectura de todos los eventos psicológicos (Ribes y López, 1985; Ribes, 1990; Kuhn, 1971).

1 En la mayoría de de los casos se trata de un reduccionismo de los fenómenos psicológicos a fenómenos de otras ciencias. En la actualidad, algunos psicólogos suponen, erróneamente, que lo psicológico tiene su origen en el cerebro y se desarrolla como un fenómeno cerebral, por consiguiente, terminan por elaborar "explicaciones psicológicas" mediante el funcionamiento de dicho órgano. Otros creen que lo psicológico se puede explicar a través de los procesos sociales y basta con conocer la sociedad para entender al individuo en su desarrollo ontogenético. Estas posturas presentan serias dificultades para justificar su existencia y pertinencia dentro del corpus científico (véase Bunge, 1989; Bunge, 1980; Ribes y López, 1985).

2 En realidad, son pocos los trabajos interdisciplinarios serios y legítimos vinculados a la psicología. Por el contrario, son múltiples las propuestas absurdas que pretenden hacerse pasar por novedosas líneas de pensamiento. Especialmente aquellas que provienen de una inmensa cantidad de personas ajenas a la psicología que se han encargado de relacionar esta disciplina con cualquier cosa que se les ocurra. Por ejemplo, psicología del color, psicología del arte, psicología de la angelología, psicología positiva, psicología de la ecología, psicología del clima, psicología transpersonal, psicología de las neuroventas, etc. La fórmula les ha sido bastante simple: solamente se debe agregar la palabra "psicología" o usar el prefijo "psico" antes de mencionar la disciplina o tema de interés, como psicomagia, psicoembriología, psiconeuroendrocrinoinmulogía, psicología del derecho, psicología de la vejez, y muchas más. 
Entonces, dado que el estado actual de la psicología es un desorden, optaré por adherirme a aquella psicología que se apegue a las características de una ciencia, ya que ésta es la psicología que se encuentra en las condiciones mínimas para el entendimiento del suicidio y, por lo tanto, de incidir de manera significativa en la vida cotidiana con hechos concretos.

Dicho lo anterior, describiré las teorías psicológicas que más aportes han dado para explicar el suicidio, no sin antes advertir que, si la psicología es una disciplina ecléctica debe quedar claro que las diversas teorías del suicidio no hacen referencia a lo mismo, aun cuando utilicen las mismas palabras para explicarlo. Tampoco son teorías equivalentes entre sí, ni mucho menos están haciendo referencia a lo mismo con otras palabras.

\section{Teorías psicológicas del suicidio}

Actualmente, existen diferentes teorías, modelos explicativos y clasificaciones del comportamiento suicida provenientes de la psicología (Ferri, 1934; Göppinger, 1975; Schneidman, 1968; Stengel, 1965; Ellis, 2008), de la rama psiquiátrica de la medicina (Farberow y Schneidman, 1961), otras tantas de corte sociológico y criminológico (Dukheim, 2012; Morón, 1977; Middendorff, 1978) e incluso algunas desde el área genética (Miles, 1977; Bobes, Sáiz, García-Portilla y Bousoño, 1996). Me centraré únicamente en las teorías de orden psicológico y explicaré brevemente de qué tratan aquellas que son las dominantes en el tema por su gran influencia.

\section{a) Teoría Cognitiva de Beck}

Para Aaron Beck, el suicidio forma parte de un contexto más amplio de la depresión. De acuerdo con su teoría cognitiva, los individuos elaboran categorías mentales en función de sus experiencias. Con dichas categorías los individuos perciben, estructuran e interpretan la realidad. Las categorías distorsionadas generan depresión, la cual provoca conducta suicida, producida porque el individuo elabora una imagen distorsionada de la realidad (Beck, 1979). Estos procesos cognitivos operan como codificación, almacenamiento y recuperación de la información con base en el tipo de estructura cognitiva.

Beck sostiene que los pacientes con tendencias suicidas muestran pensamientos negativos y creencias disfuncionales. Dichos pensamientos y creencias están vinculados con el intento de suicidio, es decir, todo acto autodañino consciente y dirigido a la autodestrucción. Las creencias se consideran como mapas internos que dan "sentido" al mundo con base en las experiencias construidas y generalizadas. En el caso del suicida es común que las creencias generen diferentes distorsiones cognitivas como la abstracción selectiva, sobregeneralización, magnificación y minimización, personalización, pensamiento dicotómico, culpabilidad, etiquetas globales y muchos otros. El producto inmediato de estas distorsiones son los pensamientos que orientan el comportamiento suicida.

Así, la principal función del psicólogo terapéutico con personas suicidas consiste, en primer lugar, en identificar las categorías que distorsionan la percepción objetiva de la realidad. Lo que se intenta es cambiar o corregir esas creencias falsas que subyacen en la mente. ¿Cómo se hace eso? A través de una restructuración cognitiva que consiste en la identificación y cuestionamiento de los pensamientos desadaptativos de las personas. Estos pensamientos deben ser sustituidos por otros más apropiados que rechacen o eliminen aquellas emociones y conductas autodañinas. 
Una de las pruebas psicológicas derivadas de esta postura es la Escala de Ideación Suicida, que tiene como finalidad evaluar y cuantificar la intencionalidad suicida, esto es, la intensidad con la que una persona pensó o está pensando suicidarse. La prueba evalúa varias dimensiones cognitivas como los pensamientos, planes expectativos y los deseos de morir y cometer suicidio. Respecto a este instrumento, hay que decir que no se han realizado estudios de validación en nuestro país, y sólo disponemos de algunas adaptaciones o traducciones al castellano. Más adelante volveré a retomar esta prueba y otras más para hacer un análisis crítico detallado.

\section{b) Teoría de Kelly y sus constructos personales}

La teoría de los constructos personales de Kelly parte del siguiente supuesto: la realidad es independiente de la interpretación que cada individuo hace de ella, y es esta interpretación del individuo respecto a la realidad la que orienta y condiciona su propio comportamiento. La Teoría de Kelly (1961) explica que el suicidio es un acto en el cual el individuo trata de validar la vida, es decir, de darle un sentido. Entonces, son dos razones principales por las que una persona llega a cometer suicidio: 1) el futuro no tiene ninguna motivación para el suicida y 2) al ser una persona prescindible se ve "obligado" a dejar todo.

El suicidio es, al igual que en la Teoría de Beck, una manifestación extrema de depresión y de un sistema de construcción de la realidad que está distorsionado por defecto o por algún rechazo a la vida en particular. Su subjetividad determina por encima de cualquier cosa los intentos de suicidio y el acto consumado.

\section{c) Teoría del comportamiento suicida de Linehan}

La teoría de Linehan sostiene que el comportamiento suicida es un método que se aprende para combatir el sufrimiento emocional. El comportamiento suicida es conceptualizado como un déficit en las habilidades para solucionar los problemas que se presentan diariamente y que pueden derivar otras problemáticas (Linehan, 1993). Todo aquel que se suicida busca la muerte como una solución única y definitiva para detener el sufrimiento. De acuerdo con este autor, en la mayoría de los casos la cognición es la principal causa de los suicidios, pues en ella se lleva a cabo la actividad que regula el comportamiento. Sin embargo, la cognición no regula de forma absoluta en todos los contextos. Los estímulos ambientales también regulan, o incluso pueden llegar a provocar cogniciones y emociones problemáticas. Entonces, con base en lo anterior, afirma que la cognición es la mediadora entre lo ambiental y el comportamiento.

Por otro lado, esta teoría sostiene que algunas personas suicidas son producto de cierta vulnerabilidad biológica que consiste en la falta de regulación de las emociones desde la etapa infantil y que puede ser detonada sin estar conscientes. La investigación realizada bajo esta teoría menciona que las conductas suicidas están vinculadas, principalmente, con el estatus económico, pérdidas interpersonales, separaciones y divorcios.

\section{d) Teoría de la Separación}

Robert Firestone propone su Teoría de la Separación desde un enfoque teórico que describe el proceso del suicidio como la internalización de pensamientos negativos (Firestone, 1988). Firestone desarrolla su teoría a partir de su concepto de la división de la mente que está conformado por el selfy el antiself. El self refiere a la personalidad innata en la mente de la persona, sus rasgos temperamentales y la armonía de relaciones interpersonales. Mientras que al antiself 
es el elemento defensivo y destructivo de la personalidad, que tiene la función de lidiar con aquellas experiencias que causan dolor emocional y frustración. Estas dos fuerzas internas se encuentran dentro de los individuos y están en constante oposición y dinamismo. El suicidio ocurre cuando el antiself triunfa por encima del self, es decir, vence el aspecto destructivo.

El objetivo terapéutico, desde esta perspectiva, empieza con la identificación del tipo de conductas que están siendo orientadas a sí mismo o hacia los demás para determinar si corresponde dicho comportamiento al self o al antiself.

\section{e) Teoría Psicoanalítica ${ }^{3}$}

La lectura del suicidio desde la propuesta psicoanalítica es la más recurrida entre psiquiatras y psicoterapeutas ortodoxos. Si bien, Sigmund Freud, creador del psicoanálisis, no desarrolló ampliamente el tema del suicidio, sí dejó algunas referencias, especialmente en su obra Más allá del principio de placer (1996a). Freud lo definió como aquella manifestación de un instinto o pulsión de muerte asociado a la agresividad que busca constantemente la calma. Esta manifestación es inicialmente orientada hacia otra(s) persona(s) pues al no poder expresarla matándola(s) se dirige a sí mismo. Una manifestación o padecimiento de suicido latente podría ser la melancolía, tal como lo menciona el propio Freud (1996b):

La melancolía se singulariza en lo anímico por una desazón profundamente dolida, una cancelación del interés por el mundo exterior, la pérdida de la capacidad de amar, la inhibición de toda productividad y una rebaja en el sentimiento de sí que se exterioriza en autorreproches y autodenigraciones y se extrema hasta una delirante expectativa de castigo [...] nos aclara el enigma de la tendencia al suicidio, que tan interesante y tan peligrosa hace a la melancolía. (p. 249)

Desde el psicoanálisis, el suicidio se entiende que es un proceso cuyo origen es el deseo de matar a otro. ¿A cuál otro se refiere? Primordialmente, a un ser amado. Las personas se suicidan como resultado de la oposición de los impulsos de vida y muerte, es decir, se produce un desequilibrio entre las tendencias constructivas y destructivas, en donde terminan por vencer las primeras.

3 No considero a la escuela psicoanalítica como parte de la historia de la psicología, no obstante, numerosos colegas e instituciones educativas se han encargado de insertarla dentro de la disciplina por su influencia en diferentes teorías actuales. En realidad, la gran mayoría de las ocasiones se le incluye por ignorancia. Es claro que un análisis histórico minucioso deja evidente que el psicoanálisis no tiene lugar en la psicología como conocimiento específico dentro del corpus científico (véase al respecto Kantor, 1990; y Szasz, 2002b). Aun en el caso contrario, es decir, que formara parte de la historia de la psicología, no considero que las diversas teorías psicoanalistas sean científicas. Considero que la aplicación de varios de sus conceptos, como el de "instinto" y "pulsión", en la explicación del ser humano parten más de un punto de vista filosófico que de una verdadera hipótesis científica. La inclusión que aquí hago del psicoanálisis es para continuar con la tradición de los libros introductorios a una temática y por el posible interés del lector. 
Las propuestas posteriores a Freud, durante los años cuarenta, explican el suicidio de manera similar, o sea, postulando que existe un lugar dentro de nosotros donde se libra una lucha interna de fuerzas en la que terminan ganando las destructivas. Sin embargo, las interpretaciones psicoanalíticas se han ido modificando desde entonces, por ejemplo, existe aquella que conceptualiza al suicidio como un renacimiento de volver a la madre resultado de una fusión del "yo" y del "superyó" (Futterman, 1961). Otra interpretación, menos extravagante que la anterior, es aquella que sostiene que el suicidio se da como una reacción a la frustración y hostilidad sin necesidad de la existencia de un impulso de muerte.

Debo hacer al lector de su conocimiento que existen muchas teorías del suicidio y cada día se elaboran más. Unas con mayor o menor éxito que otras. Dar cuenta de todas las teorías existentes escapa a los propósitos de este capítulo. De hecho, con estas que menciono son más que suficientes, pues todas ellas comparten las mismas limitaciones teóricas y conceptuales que más adelante se mencionan.

Todas las teorías coinciden en que la principal tarea para comprender el suicidio y solucionar su problemática social es mediante la reconstrucción del aparato cognitivo, psíquico o mental de las personas de acuerdo con la realidad. Posteriormente, se debe de proporcionar las habilidades necesarias para una mejor integración social. El "arreglo mental" es una condición necesaria para evitar el suicido, pues es la cognición la que determina la conducta de cada persona.

A partir de estas conceptualizaciones de las psicologías acerca del suicidio se ha derivado y desarrollado una terminología especializada consistente para construir un esquema de las situaciones relacionadas con este tipo de comportamiento (Ellis, 2008; Quintanar, 2008). Algunos de los términos más representativos son los siguientes:

- Ideación suicida: se refiere a cualquier pensamiento recurrente y reportado por la persona con intención de suicidarse, por ejemplo, la planeación específica del suicido. Esta ideación suicida podría considerarse como una fase inicial necesaria que está presente en todos los suicidios.

- Intento de suicidio: es todo aquel comportamiento potencialmente autohiriente con un resultado no fatal. El intento de suicidio es la evidencia de que la persona tuvo en algún grado la voluntad de matarse a sí mismo.

- Suicidio consumado: es aquella conducta autodestructiva que termina con la propia vida de la persona que lo llevó a cabo.

- Cooperación o asistencia al suicidio: refiere a la participación de la(s) persona(s) que sirve de ayuda para alcanzar la meta de quien pretende suicidarse.

- Eutanasia: es aquel acto intencional y consciente que de manera directa o indirecta acorta la vida de una persona enferma incurable con el fin de evitar cualquier tipo de sufrimiento.

- Inducción al suicidio: se refiere a crear una voluntad suicida en una persona que antes no existía y que da como resultado el suicidio.

- Suicidio colectivo: son aquellas conductas autodestructivas que se llevan a cabo en un grupo de personas. Este tipo de suicidios en masa se caracterizan por la participación de una persona "líder" del grupo que induce a su grupo de "seguidores" a suicidarse.

- Suicidio localizado: este tipo de suicidio se lleva a cabo como la autoaniquilación de alguna parte en particular del cuerpo. Se considera que puede ir desde comerse las uñas hasta las automutilaciones de partes completas del cuerpo como las piernas o brazos. 
- Suicidio orgánico: se dice que es cuando en el proceso de suicidio existe una fuerte influencia a un daño orgánico que determina alguna afectación a nivel psicológico.

- Gesto suicida: es toda aquella amenaza o advertencia por parte del suicida.

Esta nomenclatura es frecuentemente utilizada entre los psicólogos y psiquiatras para identificar el tipo de suicidio y la posible etapa en la que se encuentra una persona suicida. La mayoría de las teorías psicológicas describen al suicidio como un comportamiento que ocurre a través de una serie de fases que involucran procesos mentales muy particulares.

En mi opinión, esta nomenclatura "especializada" no es más que una clasificación morfológica de aquellas conductas típicas de los suicidas en diferentes momentos del continuo conductual, pero descritas al margen de la situación en las que tiene lugar. Esto da pie para señalar las limitaciones que poseen las teorías anteriores y aquellas que se adhieren con la misma lógica.

\section{Limitaciones de las teorías psicológicas del suicidio}

El estado actual de las teorías psicologías del suicidio es la de un panorama difuso para quien se inicia en el estudio del tema. Incluso para los profesionales o expertos en el tema les resulta difícil orientarse con precisión entre la amplia diversidad de teorías y enfoques. Sin embargo, gran parte de las psicologías coinciden e insisten en el desarrollo del estudio del suicidio bajo el paradigma dualismo mente-cuerpo. Freeman y Reinecke (1995) dan cuenta de esto desde la psicología cognitiva dominante en México:

La conducta suicida se produce en el medio sociocultural e indudablemente está influida por una variedad de factores físicos y bioquímicos. En primer lugar, es un estado mental. Es decir, cada acto suicida se inicia en la mente del individuo. Es ahí donde debemos acudir si tratamos de comprender y resolver este problema. (p.18)

De acuerdo con esto, en nuestra mente se generan ideaciones suicidas y las llevamos a cabo a través de nuestro cuerpo. La mente, que "maquila" todo, es inobservable, mientras que su consecuencia directa, el comportamiento suicida, es observable. Así, desde esta visión del humano, el suicidio es resultado de las operaciones o actividades mentales tales como el pensamiento y la imaginación, de ahí el énfasis de psicólogos y psiquiatras por resolver este problema por medio de una restructuración cognitiva.

Es justamente aquí donde encontramos el origen de las limitaciones de las actuales teorías acerca del suicidio: la concepción dualista mente-cuerpo del ser humano. Este problema, que sigue arrastrando la psicología moderna, se puede localizar desde la época del Renacimiento a partir de los postulados de René Descartes. La filosofía cartesiana acerca de la constitución del ser humano en dos mundos cualitativamente distintos es la siguiente: el primero de ellos, el cuerpo tiene lugar en el espacio-tiempo y se rige bajo los principios de la física mecánica. El segundo, el alma es puramente temporal y se encuentra contenido en el cuerpo y obedece a distintos criterios de la física mecánica. 
La psicología, como estudio del alma o mente durante la época renacentista, era una disciplina que se encargaba (y aún lo sigue haciendo -afirman la mayoría de los colegas-) de estudiar la interacción entre el conocimiento y la acción del cuerpo. La psicología actual se construyó sobre el dualismo mente-cuerpo que postula la filosofía cartesiana. Casi todas las psicologías, en tanto dualistas, son ejemplos claros de la herencia cartesiana, y las teorías acerca del suicidio, mencionadas anteriormente, no escapan a esto. La herencia del pensamiento cartesiano fue la de un objeto de estudio imposible de analizar empíricamente para la psicología y cualquier otra disciplina.

¿Cuál es la limitación que tiene el dualismo? Filósofos como Turbayne (1974) y Ryle (2002) sostienen que la construcción del mito cartesiano en realidad se basa en postulados erróneos. Este último, Ryle, menciona que el dualismo mente-cuerpo se trata de un error categorial. Él lo ha llamado el Mito del Fantasma en la Máquina, el cual consiste en suponer que el comportamiento es causado por una actividad interna, privada y no observable que llamamos de forma genérica como "mente". El mito del fantasma en la máquina tiene severas contradicciones lógicas. Uno de ellos consiste en afirmar la existencia de un mundo independiente del cuerpo, que no tiene extensión espacial sino sólo temporal, se vea contenida en algo como el cuerpo, más específicamente dentro de la cabeza como sostienen algunos neuropsicólogos. Simplemente, no es posible que el pensamiento o la mente constituya un evento causal del movimiento del cuerpo ya que para que ocurra cualquier movimiento del cuerpo es necesario un contacto directo con algún evento que se encuentre en el tiempo y espacio, no sólo en el tiempo.

Incluso en el caso de que se llegara a aceptar que la mente es la causante de nuestro comportamiento, nos enfrentaríamos a otro problema igualmente grave: se trata de una explicación bajo la lógica causal mecanicista que necesariamente se requiere un causante previo para su ocurrencia. Es decir, si el comportamiento es provocado por las operaciones mentales, estas últimas también deben tener una causa previa, y éstas a su vez deben tener otra causa, etc. Entonces, en la causalidad mente-cuerpo se requiere conexiones necesarias, por lo tanto, caemos en una regresión al infinito hasta la causa inicial de todo.

Cuando nos preguntamos, ¿qué pasa por la mente de la persona cuando decide suicidarse? La respuesta es simple: no pasa nada. A la luz de lo planteado por Ryle, resulta imposible sostener lógicamente que el suicidio tiene como causa responsable algún episodio oculto dentro de nosotros y que provoca los actos suicidas.

Lo único que ha hecho el dualismo psicológico es dar un tratamiento erróneo al comportamiento suicida y una doble tarea para los psicólogos. ¿Por qué doble tarea? Porque al postular dos mundos cualitativamente distintos se requiere de diferentes tratamientos para cada uno. Por supuesto, esto tiene implicaciones en las aplicaciones clínicas. Por un lado, se hace uso de técnicas cognitivas (ensayo cognitivo, focalización, consecuencias fantaseadas, desarrollo de disonancia cognitiva, etc.). Y por el otro, técnicas conductuales (ensayo conductual, terapia de role play, exposición en vivo, entrenamiento de habilidades y asertividad, etc.). Las primeras intervienen o modifican la cognición, mientras que las segundas a la conducta.

Esta división del ser psicológico que está compuesto por una mente y un cuerpo por separado, pero unidos de manera misteriosa, ha derivado en diferentes formas de abordar el suicidio con implicaciones importantes desde la psicología y su aproximación al suicidio: 1) la visión organocéntrica del suicidio y 2) la visión de la anormalidad del suicidio. 


\section{Perspectiva organocéntrica del suicidio}

El organocentrismo psicológico consiste en aquella explicación que restringe la conducta humana o animal a comportamiento puramente biológico. Se trata de un tipo de reduccionismo que es común de encontrar en casi cualquier teoría psicológica actual. Esta visión de lo psicológico se centra más en los aspectos biológicos que tienen lugar en un órgano específico más que en la interacción del organismo como unidad total con el entorno. Por ejemplo, el cerebro o partes específicas de este.

Es claro que todo fenómeno psicológico implica necesariamente numerosos eventos biológicos, por lo tanto, ningún estudio de los hechos psicológicos debe ignorar las funciones biológicas de cada individuo u organismo. Por el contario, es preciso conocer un mínimo de las condiciones biológicas necesarias para su ocurrencia, tales como son los rasgos morfológicos, fisiológicos y evolutivos del organismo en cuestión.

Sin embargo, esto no implica que lo fenómenos psicológicos sean idénticos en su naturaleza a los biológicos, ni que puedan explicarse en última instancia por la ciencia biológica. Por ello, quisiera hacer algunas aclaraciones respecto a las explicaciones que se han divulgado en las últimas décadas en relación con los mecanismos del cerebro y nuestro comportamiento psicológico, especialmente en aquellas que tienen que ver con el suicidio. ¿A qué tipo de explicaciones me refiero? A aquellas que se han distorsionado a partir de las teorías e investigaciones provenientes de las llamadas psicología fisiológica, neuropsicología y ciencias cognitivas, las cuales han ganado amplio terreno en la psicología (Thompson, 1973; Lezak, Howieson y Loring, 2004; Rains, 2004; Álvarez y Trápaga, 2008).

La psicología contemporánea se ha orientado y desarrollado en dirección hacia el cerebro desde hace varios años. La principal disciplina encargada de esto es la Neurociencia Cognitiva ${ }^{4}$. El objetivo de las llamadas neurociencias cognitivas es determinar cómo el funcionamiento cerebral da lugar a lo que se conoce como actividad mental y esclarecer su relación con la conducta (Alcaraz y Gumá, 2001; Gross, 2007). La supuesta actividad mental se refiere, a grandes rasgos, a las operaciones que realiza una entidad inmaterial cognitiva cuya función es controlar nuestro comportamiento. Para estudiar estos procesos cognitivos, los especialistas se valen de las tecnologías más avanzadas disponibles, entre las que destacan por su gran impacto: las técnicas de bioquímica cerebral, imagenología funcional cerebral, receptores celulares, dispositivos electrónicos implantados en el cráneo, neuroimágenes y electroencefalograma. De hecho, gran parte de los avances teóricos de las neurociencias se han visto enriquecidos con las mejoras tecnológicas de cada día.

Sin embargo, aun cuando la tecnología ha avanzado demasiado rápido y ha permitido transformar nuestras ideas acerca del mundo, la mayoría de los psicólogos han confundido los niveles de análisis de estudio de la realidad y, de forma errónea, han reducido las explicaciones psicológicas a procesos cerebrales.

¿Por qué esto es así? La historia se remonta de siglos atrás para entender el por qué volteamos a ver al cerebro y privilegiamos sus funciones a tal grado de querer explicar todo el comportamiento humano y animal en última

$4 \quad$ Por razones de exposición englobaré bajo este nombre a todas aquellas ramas de la psicología que estudian la correlación de los eventos biológicos con los psicológicos. Si bien es cierto que existen diferencias entre cada una de las ramas, todas ellas comparten la búsqueda de las relaciones de correspondencia entre la mente, cerebro y comportamiento. 
instancia con conexiones entre neuronas. No obstante, mencionaré brevemente dos razones importantes por las que en los últimos siglos esto ha sido así hasta la actualidad.

Una razón la encontramos en el texto Tratado de las pasiones de René Descartes en su intento por naturalizar el alma (mente) para explicar su relación con el cuerpo. ¿Por qué quería naturalizarla? Porque la res cogitans cartesiana (sustancia mental) ocupaba la coordenada temporal pero no la espacial, eso representaba un enorme problema (y aún lo sigue siendo) para explicar su interacción con el cuerpo. ¿Cómo explicar la interacción de dos objetos, el cual uno de ellos no se encuentra en el espacio? Descartes, quien era un hombre de ciencia, sabía que la física mecánica newtoniana de su tiempo explicaba perfectamente el movimiento de todos los cuerpos u objetos. Todo cuerpo ocupaba necesariamente un lugar y un tiempo determinado para ser movido por otros cuerpos. Por tanto, se requería explicar cómo y dónde ocurrían las operaciones de la res cogitans y así dar cuenta de su relación con el cuerpo. La solución de Descartes fue desplazar el alma a una parte del cuerpo:

También es necesaria saber que aunque el alma esté unida a todo el cuerpo, hay en él sin embargo una parte en la que ejerce sus funciones más particularmente que en todas las demás. Y se cree comúnmente que esta parte es el cerebro o, acaso, el corazón; el cerebro, porque a él se refieren a los órganos de los sentidos; y el corazón, porque en él sentirse las pasiones. Pero, examinado la cuestión con cuidado, me parece haber reconocido con evidencia que la parte del cuerpo en la que el alma ejerce más particularmente sus funciones no es de ningún modo el corazón, ni tampoco el cerebro, sino sólo la más interna de sus partes.

La razón que me ha hecho persuadirme de que el alma no puede tener en todo el cuerpo ningún otro lugar que esta glándula en la que ejerce inmediatamente sus funciones, es la consideración de que las demás partes de nuestro cerebro son todas dobles, lo mismo que tenemos dos ojos, dos manos, dos orejas y, en fin, lo mismo que todos los órganos de nuestros sentidos externos son dobles; y puesto que sólo tenemos un pensamiento único sobre una cosa al mismo tiempo, es preciso necesariamente que exista algún lugar en el que las dos imágenes que vienen de ambos ojos, u otras dos impresiones cualesquiera, que vienen de un sólo objeto por los órganos dobles de los sentidos, puedan unirse en una antes de llegar al alma, para que no le representen dos objetos en vez de uno. Y se puede concebir fácilmente que estas imágenes u otras impresiones se junten en esta glándula por medio de los espíritus que llenan las cavidades del cerebro; pero no hay ningún lugar en el cuerpo en el que puedan estar así unidas, sino después de estarlo en esta glándula. (1994, pp. 101-102)

Como podrá darse cuenta el lector, esta explicación no se sustenta bajo ningún estudio empírico. Más bien fue un recurso necesario, pero desafortunado, para que el sistema cartesiano "cerrara". A partir de esta afirmación, se daría inicio a la psicología fisiológica y formar parte de la historia de las neurociencias modernas de nuestros días.

Cabe destacar que no siempre se pensó que nuestra cabeza era el lugar donde ocurrían procesos o estados mentales. En la antigüedad se creía que cuando pensábamos y sentíamos lo hacíamos con el corazón, mientras que en los pulmones se encontraban las partes afectivas. Actualmente, existen seudopsicologías que sostienen que las emo- 
ciones tienen lugar, literalmente, en una parte específica del cuerpo (López, 1997; 2006). Esta visión es resultado de un análisis poco crítico. Por encima todo, es una perspectiva reduccionista de los fenómenos psicológicos. La diferencia entre estos dos tipos de organocentrismos, el antiguo y el actual, radica en que las primeras están ancladas en explicaciones de orden natural, mientras que las segundas son productos de la confusión y la mezcla de diferentes mitos.

Con el antecedente cartesiano se construyó la segunda razón por la que los psicólogos actuales se centran en el estudio del cerebro. Se trata de la influencia del pensamiento filosófico materialista del siglo XIX. La lectura de los materialistas acerca de los fenómenos psicológicos era que todos los eventos mentales (y espirituales) se ubicaban en la materia y sus procesos. Este tipo de materialismo afirma que las ideas, sentimientos, emociones, inteligencia y todos los fenómenos que involucran los eventos “mentales" se podían explicar sobradamente como el resultado de procesos químicos y eléctricos en el cerebro. Por lo anterior, existe una gran cantidad de libros y revistas especializadas acerca de las bases biológicas de conducta psicológica. Todo se puede reducir en la siguiente frase tan popular: "El pensamiento es al cerebro como la orina a los riñones".

Esta visión organocéntrica de lo psicológico se ha popularizado a través de diversos programas de televisión, documentales y revistas de divulgación científica. Casi todas las investigaciones de "vanguardia" siguen esta línea de privilegiar al cerebro como nunca se había hecho. De hecho, ya sea conocimiento especializado o no, se sostiene que las funciones del cerebro de un organismo determinan sus acciones y constituyen la base de todo proceso y estado "mental". La mayoría de las perspectivas neuropsicológicas se adhieren a esta perspectiva, como dan cuenta Ardila y Rosselli (2007):

Pero desde hace apenas un par de siglos suponemos que el cerebro es responsable de la actividad psicológica, es decir, recordamos con nuestro cerebro, hablamos con nuestro cerebro y pensamos con nuestro cerebro. O más exactamente, quien recuerda, habla y piensa es nuestro cerebro; lo que llamamos actividad psicológica es simplemente la resultante de nuestra actividad cerebral. Hace apenas un poco más de un siglo se presentaron ante la comunidad científica del momento las primeras demostraciones clínicas de que esto efectivamente era así: si se lesionan algunas áreas del cerebro perdemos nuestra capacidad de hablar; si otras áreas son afectadas, no seremos capaces de pensar lógicamente y comportarnos racionalmente; y aun si otras más sufren daño, no podremos recordar lo que nos sucedió un momento antes. (p. xv)

Es muy frecuente que se equipare a la mente con el cerebro como si se tratasen de la misma cosa. Una gran parte de mis colegas psicólogos recurre a la etiqueta de "cerebro cognitivo" como un intento burdo por integrar dos ideas de diferente naturaleza. Otros colegas optan por "cerebralizar" todos los fenómenos psicológicos con el objetivo de hacer "más científica” a la disciplina (López y Costa, 2014). No obstante, la visión organocéntrica de lo psicológico tiene severos problemas insalvables.

El principal problema es que, si la mente y el cerebro son lo mismo, entonces todos los procesos y estados mentales ocurren en y como operaciones cerebrales. Si aceptamos esto, debemos entender que los llamados desórdenes mentales o enfermedades de la mente pasan a ser resultado de desarreglos sinápticos. Por tanto, todas aquellas psi- 
cologías que postulan algún tipo de entidad cognitiva mental como objeto de estudio para explicar el comportamiento están equivocadas. Por ejemplo, las teorías psicoanalíticas, piagetianas, cognitivas, gestaltistas, etc., son erróneas pues no remiten al funcionamiento del cerebro para sus explicaciones psicológicas. Incluso si lo hicieran, siempre encontraremos una explicación más completa en la neurología o fisiología para el estudio de la psique humana.

Sin embargo, aun si aceptamos el organocentrismo psicológico, es claro que los mecanismos del cerebro no pueden ser determinantes de nuestro comportamiento en la medida en que cualquier órgano depende de otros órganos para su funcionamiento, además de las condiciones suficientes para entrar en contacto con la estimulación ambiental. Si esto es correcto, entonces es impropio privilegiar un órgano al margen de los demás. La actividad cerebral simplemente no puede funcionar como base explicativa para las características psicológicas pues las variaciones conductuales que despliegan las personas difieren en su individualidad y esto rebasa, claramente, a cualquier explicación que se pudiera ofrecer a nivel biológico.

Por ejemplo, imaginemos a una joven modelo que sufre de un accidente automovilístico y queda paralítica. Para ella, el mundo del modelaje es todo, pero ahora jamás podrá hacerlo de la misma forma. Consecuencia de esto, le "vienen a la cabeza" diferentes ideas suicidas con bastante frecuencia. Una explicación cerebral sostendría que este órgano es quien organiza toda la información y con base en ello elabora los pensamientos suicidas. Además, el cerebro es quien manda señales al sistema endocrino para segregar sustancias que hacen sentirnos deprimidos. Nuestro cerebro hace que percibamos todo como una desgracia ${ }^{5}$.

No obstante, en el sentido estricto es incorrecto afirmar que del cerebro surgen los pensamientos suicidas. El cerebro no lo puede hacer solo, pues depende de otros factores determinantes para la situación específica en la que nos comportamos. En el ejemplo de la joven modelo existen diferentes condiciones necesarias para que emerjan los llamados pensamientos suicidas: el accidente automovilístico, que se dedicara al modelaje, las acciones de las personas que se relacionan con ella, etc.

Por otro lado, desde hace ya algunas décadas se han realizado increíbles estudios acerca del papel que tienen los genes en nuestro comportamiento, en especial en lo que refiere a la información que proporcionan acerca del funcionamiento de nuestros órganos. No obstante, el funcionamiento de los genes no puede ofrecer una explicación que abarque los diferentes desarrollos conductuales en su dimensión individual. Esto es así porque los genes, si bien son una parte necesaria para el comportamiento de cualquier organismo, no son suficientes para dar cuenta por sí mismos el desarrollo psicológico.

Ciertamente, nuestra genética determina diferentes cualidades en cada persona, pues siempre están presentes en cada una de nuestras acciones. Pero no existe un "gen suicida" que explique el comportamiento de los suicidas. No se sostiene la afirmación de que hay personas que nacen con tendencias suicidas a causa de su genética. No hay herencia biológica familiar suicida o algo similar. De hecho, hoy en día cualquier genetista admite que incluso aquellos comportamientos muy particulares de organismos con condiciones genéticas excepcionales, cobran existencia sólo mediante la interacción con el medio ambiente.

$5 \quad$ Note el lector que a veces hablamos como si nuestro cerebro fuera algo adicional y distinto a nosotros mismos. 
Pensemos por ejemplo en el extraordinario nadador olímpico Michael Phelps. Este atleta posee una estructura ósea que le permite desempeñarse de manera formidable en el deporte acuático de alto rendimiento gracias a su genética. No obstante, el hecho de que los genes favorezcan su condición biológica, no debe pensarse que estos determinan su actividad atlética. Es decir, es necesario el aprendizaje de las técnicas de nado, una alimentación adecuada, entrenamiento constante y disciplinado, etc. Si Michael Phelps hubiera crecido en un país donde no se fomentara el deporte como actividad de recreación o profesional, es probable que nunca hubiera llegado a ser el mejor atleta de nado en Juegos Olímpicos. Por más que tuviera los mejores genes de la humanidad hubiera sido simplemente imposible. No sólo eso, nadie podría sospechar, incluyendo al propio deportista, de su extraordinaria genética sino es hasta después de haber desarrollado un comportamiento particular en el agua.

Debo aclarar que en los problemas que planteo no estoy cuestionando el conocimiento y los avances en la biología acerca de los estados cerebrales o de la importante función de los genes en nuestro comportamiento. Las explicaciones de las ciencias biológicas son correctas. El verdadero problema somos los psicólogos que confundimos los niveles de explicación. Hemos reducido los fenómenos psicológicos a los complicados fenómenos biológicos.

Hoy en día, la mayor parte de los psicólogos y médicos psiquiatras siguen esta lógica errónea y creen que el suicidio se debe a la manifestación de una enfermedad orgánica del cerebro. Estos expertos afirman que dependemos de las "decisiones" que el cerebro nos ordena y que en el caso particular de los suicidas lo que ocurre es que los neurotransmisores provocan la sensación de tranquilidad a la persona, por esta razón no hay forma de evitar el suicidio de forma voluntaria (Maya, 2014).

Sin embargo, el psicólogo y el psiquiatra no rquieren estudiar neuronas, neurotransmisores o el sistema endocrino para poder conducir su análisis del suicidio. El tipo de explicaciones que ofrecen no deben de yuxtaponerse con el de otras disciplinas. Es posible que el psicólogo no conozca absolutamente nada acerca de la fisiología humana para determinar cuáles son las relaciones funcionales entre el organismo y el ambiente, es decir, las interacciones psicológicas. De hecho, casi siempre ocurre al revés, para detectar algún daño cerebral o alguna "enfermedad mental" requerimos necesariamente de algún indicador conductual para su identificación, es decir, una interacción entre el organismo y el ambiente (véase los casos clínicos de Sacks, 2002).

No estoy negando de ninguna manera que la comprensión de los procesos fisiológicos nos ayude a entender los procesos conductuales en el suicidio, sin embargo, nunca serán suficientes para una explicación en un nivel psicológico. Todo fenómeno psicológico es al mismo tiempo un evento biológico, pero eso no significa que los fenómenos psicológicos sean equivalentes a las acciones de estructuras particulares, células u órganos específicos de forma aislada.

La principal crítica es hacia la lógica de cómo se han construido las teorías, en especial las neuropsicológicas y neurocognitivas, que pretenden explicar los fenómenos psicológicos. Éstas pretenden igualar los fenómenos psicológicos con reacciones químicas que ocurren a nivel biológico en las personas. Considero que aquellas explicaciones fisiológicas y neurológicas que pretenden esclarecer la conducta psicológica de los individuos no son más que formas exageradas de una reducción materialista. Claro, es necesario que se tenga una base material, biológica en este caso, pero la conducta psicológica no se agota únicamente con eso. Se está tomando una condición necesaria para que sea posible algo con una explicación de ese algo. 
Es cierto que determinadas alteraciones en el cerebro pueden disponer a alteraciones conductuales y, entre ellas, el suicidio. Pero no significa que dichas alteraciones sean las causas de nuestra conducta, ni sea el sitio donde ocurre el pensamiento suicida y mucho menos eso sea en sí mismo el suicidio. Las alteraciones biológicas del sistema nervioso, sistema endócrino y de las condiciones orgánicas generales afectan la forma en que se comportan los individuos, por ejemplo, el caso de la depresión endógena, que es un problema a nivel de neurotransmisores (serotonina).

Quintanar (2008) menciona que la depresión es el padecimiento que más se ha encontrado asociado al suicidio. No obstante, agrega que esto no significa que no existan otras formas de suicidio desvinculadas a alteraciones biológicas o no tengan un sustento diferente al biológico, es decir, de índole social. Existen varios casos que ejemplifican esto: los rituales suicidas de los monjes budistas, la autoinmolación de las viudas de la India, los samuráis y su Harakiri en la historia de Japón, los suicidas que atentan en actos terroristas como en el caso de las Torres Gemelas en Nueva York, cuestiones políticas como los suicidios de Adolf Hitler en la Alemania Nazi o de Salvador Allende en Chile.

Entonces, ¿qué pasa con las teorías psicogenéticas o psiconeurólogicas? ¿acaso están equivocadas? ¿cuál es el lugar que hay que darles a estas teorías? Campanilla (1985) menciona que algunas teorías psicogenéticas sostienen que se transmite una herencia específica del suicidio, e incluso las enfermedades mentales, y que las investigaciones bajo dichas teorías han encontrado que las personas biológicamente relacionadas con suicidas tenían tasas más altas de muerte que los relacionados por adopción. Sin embargo, esto no significa que el suicidio sea enteramente un patrón genéticamente determinado, sino más bien que los individuos están en algún proceso en el que un evento puede desencadenar una predisposición genética. Esto explica por qué no todas las depresiones o eventos estresantes llevan necesariamente al suicidio, sino sólo en algunas de ellas, por ejemplo, aquellas en las que la actividad inhibitoria serotoninérgica es deficitaria. Por lo tanto, a todas estas explicaciones debemos darle lugar e importancia desde su nivel analítico específico. No se trata de desechar, sino de reubicar.

En resumen, es falso el supuesto de la existencia de un mecanismo mental o cognitivo que tiene su origen en el cerebro. Por tanto, el suicidio no puede entenderse sólo en términos neurológicos. Si empezamos a elaborar constructos fisiológicos del suicidio estos nos van a remitir de manera inevitable a una explicación a nivel biológico y no necesariamente psicológico. Sanmartín (2002) describe de forma ejemplar la posición de la psicología incorrecta que pretende explicar la mente de los psicópatas como un proceso cerebral:

Pero de lo dicho no debemos extraer precipitadamente la conclusión de que a los psicópatas les funciona bien toda la corteza prefrontal. Ya sabemos que es muy grande. Puede que les funcionen bien unas zonas, y otras no. Me atrevo a conjeturar que el área dorsolateral del cerebro de un psicópata funciona bien, dado que es allí donde se planifica una acción. Me atrevo a conjeturar que, además, les funciona bien el área orbitofrontal -la encargada de llevar a la práctica lo decidido por la dorsolateral-. Los problemas deben de estar en otro sitio, a saber: en la corteza ventromedial, en esa zona de corteza prefrontal que dota de sentimiento a la acción ordenada por la corteza orbitofrontal. Eso explicaría el hecho de que el psicópata, como es el caso, sabe siempre lo que hace, aunque no lo siente y, por ello, es incapaz de empatizar con su víctima. 
Los (supuestos) problemas del área ventromedial del cerebro de los psicópatas deben de ser de tipo anatómico o fisiológico, y no solo de tipo social. Lo que quiero decir es que no sólo el contenido -los sentimientos-, sino también el continente (la corteza ventromedial) debe de tener alguna anomalía en estos individuos. Si sólo se tratara de malos sentimientos, una buena reestructuración cognitiva, tratando de eliminar distorsiones, podría traducirse en los adecuados cambios comportamentales. Pero no es así. Hasta el momento no se han encontrado terapias cognitivo-conductuales (o de otro tipo) que sean eficaces. (pp. 115-116)

\section{La anormalidad del comportamiento suicida: ¿condición o atribución?}

Se dice que el suicidio es un comportamiento anormal o atípico, esto quiere decir, un comportamiento que se aparta de la mayoría en la distribución normal poblacional. Son anormales tanto el "loco" que está encerrado en el manicomio como el "genio" que se le otorga un Premio Nobel. La diferencia entre ambos estriba en que el comportamiento de uno es valorado como una enfermedad mientras que el del otro como un privilegio de unos pocos.

Sin embargo, no debe pensarse que aquello que llamamos anormal lo sea por sí mismo al margen de la situación. La anormalidad no es inherente a los seres vivos, objetos y eventos de la naturaleza. El concepto de anormalidad no tiene más que el propósito social de clasificar a las personas por interés de unos cuantos.

Pero, ¿qué hay del sentido común'? Este nos indica que nadie consciente o en su "sano juicio" se quitaría la vida de forma voluntaria, y si lo hace seguramente es resultado de una enfermedad mental. Así, quien se suicida es una pobre víctima desorientada que los psicólogos y psiquiatras suelen llamar "paciente". Padece de un mal que identificamos por su comportamiento anormal.

La cierto es, y quiero enfatizarlo, que cada concepto que caracteriza a un individuo como enfermo mental en realidad es una descripción del comportamiento y no un padecimiento. Las enfermedades mentales no existen. Una conducta desaprobada no es una enfermedad orgánica como lo es el cáncer, la diabetes, la varicela, la gripa, etc. Se ha supuesto la existencia de conductas intrínsecamente anormales o desajustadas, cuando en realidad la conducta como tal ni es normal ni es anómala, tampoco es buena o mala, correcta o incorrecta.

Pero, ¿entonces cómo surgen las llamadas enfermedades mentales? El término enfermedad mental, como señala Szasz (1989), es algo más abstracto que concreto. Por un lado, la etiqueta de enfermedad mental cumple con dos funciones: 1) Anular la responsabilidad penal de los actos de quien se comporta, pues se dice que es incapaz de actuar

6 El sentido común no es de ninguna manera una lógica innata o intrínseca en los humanos que nos permite saber moralmente que es lo correcto o lo incorrecto. Tampoco es una cosa que habite en algún órgano del cuerpo como en el cerebro o sea un sentido como la vista (ojos), el gusto (lengua), la audición (oído), etc.

Por sentido común se entiende cuando los individuos nos apropiamos del discurso y lógica de la sociedad en que nos desenvolvemos, esto es, todas aquellas prácticas que realizamos y compartimos con otros. El sentido común no es invariante, inmanente, ni universal. Depende de la actividad individual con la sociedad. Desde que interactuamos en una sociedad nos comportarnos en función de los criterios de los demás y recibimos consecuencias que van regulando nuestro comportamiento, por tanto, el sentido común es algo que se aprende, aun cuando parezca algo natural o innato en nosotros. 
por sí mismo, y 2) forma parte de un mecanismo social que tiene por objetivo la regulación de las personas por parte de médicos psiquiatras y algunos psicólogos. La etiqueta de enfermedad mental no sólo tiene un trasfondo histórico, sino que también funciona al servicio del poder político y económico vigente para sus propios propósitos.

Por otro lado, el hecho de que el comportamiento sea susceptible de dicha adjetivación (enfermedad mental), se debe a que su ocurrencia se da como parte de un sistema o norma convencional. Los diversos diagnósticos psicológicos no son más que juicios de valor y que reflejan el punto de vista moral particular de una sociedad. No hay ningún misterio de anormalidad de fondo. La influencia del modelo de la medicina en la psicología ha sido notable desde sus inicios y su concepto de "anormalidad" no es la excepción, pues se deriva del modelo dicotómico de salud-enfermedad. El traspaso del concepto a la psicología acarreó también las supuestas enfermedades mentales (Ribes, 2008; Szasz, 2002b).

Los intereses de los grupos dominantes influyen y determinan socialmente en nuestros actos a través de las normas y valores que se expresan en las prácticas de cada uno de nosotros. Estas normas y valores sociales son las que establecen la normalidad y/o anormalidad de nuestros comportamientos. Los suicidios (y los trastornos mentales en general como la bipolaridad, esquizofrenia, etc.) no son más que una "anormalidad" con base en un juicio de valor social de aquello que el individuo normalmente hace al participar en una relación con un medio (Foucault, 1986; Díaz-González y Carpio, 1996; Ribes, 1990; Szasz, 2001). El suicidio nunca es por sí mismo una conducta enferma, una condición anormal, incorrecta o mala. Si una persona sumamente culta e intelectual se suicida, es posible que se valore como un acto que forma parte de su genialidad (por ejemplo, el filósofo Séneca). En cambio, si quien se suicida es alguien como un indigente, entonces es un enfermo mental víctima de la locura. Por tanto, es impreciso hablar de anormalidad en el suicidio y de todas las interacciones psicológicas en general.

No quiero que se piense que todo lo que he dicho aplica de la misma manera cuando se trata del comportamiento del asesino en serie, el violador o el "loco" y basta con justificar afirmando que depende del ojo con que se mire. Existen grandes diferencias morales entre una persona suicida y un asesino. Como hace mención Szasz (2002a), existen muchos argumentos de por qué la gente mata o debe de matar a otros, pero al parecer nunca hay justificación alguna que sea adecuada para que uno se suicide. El suicidio, por el contrario, debería ser un derecho fundamental 7 . Me sumo a la línea de pensamiento que considera que deberíamos aceptar el control de la propia muerte como una responsabilidad y decisión personal. De hecho, suicidarse no es una acción de naturaleza psicológica distinta a la de golpear, comer, dormir, llorar, reír, etc., su valoración puede ser "racional" o "irracional" dependiendo del contexto.

Ahora bien, no basta con las aclaraciones anteriores, pues es necesario analizar conceptualmente la definición del suicidio con el fin de alcanzar la claridad teórica indispensable en toda ciencia para evitar los errores inadvertidos de las teorías psicológicas actuales. La investigación y el quehacer del científico, en especial del psicólogo, depende de su claridad conceptual y teórica. Entonces, es prioridad de toda psicología definir claramente los términos que se usan para hacer referencia a los distintos fenómenos que se propone estudiar.

$7 \quad$ Valdría la pena repensar acerca de la legitimidad que poseen las instituciones de salud para llevar a cabo intervenciones que impiden que las personas tomen las decisiones de suicidarse y, por el contrario, obligarlas a permanecer encerradas bajo vigilancia. 


\section{CAPÍTUlo 3}

\section{Consideraciones conceptuales acerca del suicidio}

Dado que la palabra suicidio surge con frecuencia en el curso de las conversaciones, pudiera creerse que todo mundo conoce su significado y es superfluo definirla.

Sin embargo, las palabras del lenguaje coloquial

$y$ los conceptos que se expresan son ambiguas y el científico que las emplease tal cual, sin someterlas a una elaboración ulterior, se expondría a la más grave de las confusiones.

Emile Durkheim

Hacer un análisis conceptual de las palabras que usamos en psicología no es una actividad ociosa o una tarea adicional al desarrollar un tema dentro de la disciplina. Por el contrario, es una labor indispensable del quehacer de todo psicólogo. ¿Por qué esto es así? Porque una cantidad enorme del vocabulario que nutre a las psicologías proviene de las palabras que usamos cotidianamente y éstas poseen distintas funciones lógicas de las que se requieren en las ciencias para teorizar. Por consiguiente, es necesario identificar el sentido funcional de las expresiones psicológicas del lenguaje ordinario, es decir, aclarar qué es lo que queremos decir con los términos que usamos para teorizar, por ejemplo, palabras como motivación, inteligencia, conciencia, memoria, aprendizaje, imaginación, talento, etc. Puntualizando que es forzoso este tipo de análisis por las siguientes dos grandes razones:

1. Nos permite delimitar las distintas formas de comportamiento a las que nos referimos para su identificación y estudio empírico desde la ciencia. Si no tenemos una definición precisa que nos permita identificar empíricamente aquello que estudiamos, entonces difícilmente podremos darnos cuenta de qué está ocurriendo.

2. Para evitar la formulación de seudoproblemas que son imposibles de resolver para cualquier ciencia o disciplina. Nada tiene que ver, como la mayoría supone, con la falta de metodologías o tecnologías disponibles para dar respuesta. Los falsos problemas son imposibles de solucionar simplemente porque están mal planteados, 
y no olvidemos que el progreso del conocimiento científico depende de manera primordial de la correcta formulación del problema ${ }^{1}$.

Dicho lo anterior, es necesario mencionar algunas consideraciones respecto al lenguaje y su papel en la construcción de las teorías científicas en la psicología.

Lo primero que hay que entender es que las ciencias consolidadas se caracterizan por tener un lenguaje técnico, es decir, un lenguaje propio que sea lo suficientemente abstracto para abarcar diferentes fenómenos de la realidad en un nivel de análisis particular. A partir de dicho lenguaje, popularmente conocido como discurso científico, los científicos crean y recrean los objetos y fenómenos de la naturaleza que pretenden estudiar. ¿Qué quiere decir que crean y recrean? Significa que la ciencia "fabrica" enunciados de todos los fenómenos que observa en la naturaleza: la gravedad, la condensación, la evolución biológica, revoluciones sociales, el aprendizaje, el pensamiento, etc. Los científicos saben que todos los descubrimientos y hechos científicos están lejos de ser la verdad absoluta, por el contrario, los consideran como narraciones exitosas. Ese mundo "externo" que vemos, olemos, oímos, probamos y sentimos no es más que una creación humana como y mediante la descripción e interpretación de los hechos ${ }^{2}(\mathrm{Kuhn}$, 1971; Hanson, 1985).

Entonces, todo lo que se afirme acerca del suicidio desde la ciencia no es más que la conceptualización que se hace a partir de un lenguaje especializado. Esta conceptualización no es de ninguna manera mejor que aquellas que se elaboran fuera del ámbito científico como la religiosa, artística, jurídica, biológica, entre otras más. Por lo tanto, es incorrecto asumir que las teorías científicas son "verdaderas" o "poseen una mayor veracidad" que las tesis que se postulan desde otras disciplinas. Cada una proviene de distintas raíces ontológicas y epistemológicas. Es por eso que la gran mayoría de las disputas acerca de la supuesta superioridad de la ciencia frente a otros modos de conocimiento no tiene sentido alguno pues se tratan de distintas cosas.

Ahora bien, volviendo al tema del suicidio, no existe una concepción, ya sea dentro o fuera de la ciencia. Más bien, han sido diferentes las concepciones del suicidio a lo largo de la historia, y es lógico que esto sea así. Cada una de las conceptualizaciones cumple con funciones específicas de su tiempo, geografía e influencias de diversas instituciones sociales. A esto hay que agregar el tipo de análisis que desde una disciplina particular se elabora a partir de su aproximación al fenómeno.

$1 \quad$ El seudoproblema más representativo en psicología es aquel que postula la existencia de diversas interacciones entre la mente y el cuerpo. Por razones obvias, como lo demuestra Ryle (2002), no se ha podido solucionar desde hace siglos que lo oficializó René Descartes en sus escritos. Dado que no se trata de un genuino problema, resulta absurdo e imposible intentar resolverlo mediante experimentos. Desenredar un falso problema como este sólo es posible mediante un análisis del tipo conceptual, además de la detallada revisión histórica-social de la que emerge y se desarrolla el concepto.

2 A lo largo de los siglos se ha discutido desde la filosofía y la ciencia acerca de si aquello que llamamos "realidad" existe de forma independiente de nosotros, o más bien, se trata de un conjunto de relaciones que creamos lingüísticamente. Existen varias posturas al respecto a las que se adhieren los científicos en sus actividades de investigación con importantes implicaciones. 
El concepto suicidio, al igual que cualquier otro que refiera a un comportamiento valorado socialmente, ha evolucionado en su definición y ha retomado distintos rumbos que han hecho difícil su delimitación. Si buscamos en el diccionario, esperando encontrar el significado que ordene el panorama, este nos ofrece una definición de suicidio que es tan sólo una aproximación de lo que expresamos coloquialmente: la etimología de la palabra suicidio proviene del latín sui, de sí mismo, y caeděre, matar, y significa matarse a sí mismo (RAE, 2017).

Sin embargo, cotidianamente usamos la palabra suicidio en diferentes situaciones para expresar distintas cosas y no sólo para hacer referencia cuando uno se da muerte a sí mismo. Por ejemplo, a veces nos expresamos de la siguiente manera; "casarte en estos tiempos es un auténtico suicidio, no deberías hacerlo", "hace demasiado calor en Mexicali, irte a vivir allá es un suicidio", "ese acróbata motociclista está a punto de hacer un acto suicida", etc. En estas expresiones se usa la palabra suicidio, pero es obvio que en cada una de ellas se refiere a diferentes cosas; a los conflictos que implica la vida matrimonial, a lo difícil que puede ser vivir en un lugar con calor extremo, o en lo arriesgado de hacer una acrobacia en moto, respectivamente. Es claro que no se está haciendo alusión de un auténtico suicidio en el que alguien muere en las afirmaciones anteriores.

Por esa razón, Szasz (2002a) ha planteado la problemática que existe en el lenguaje cuando se usa la palabra suicidio para teorizar en ciencia. Este autor sostiene que para referirnos a la muerte de otro existen diferentes palabras tales como deceso, fallecimiento, homicidio, asesinato, entre otras. Pero para hacer referencia cuando alguien se mata a sí mismo sólo tenemos la palabra suicidio. Esto tiene grandes implicaciones pues nos obliga a encasillar a las diferentes muertes que se dan las personas a sí mismas en una única palabra y, por consiguiente, surgen diversas confusiones para delimitar el significado del suicidio y estudiarlo científicamente.

Resulta obvio que la palabra suicidio no está diseñada o elaborada para teorizar en la ciencia. Es una palabra que nos permite la comunicación entre las personas y que cobra significado en función de la situación particular. Por ejemplo, pensemos en algunas situaciones y tratemos de identificar en qué casos se está hablando de un suicidio y de cuáles no:

1. Una persona decide manifestarse en contra de la deforestación masiva de bosques y su forma de protesta consiste en hacer una huelga de hambre. Pasan los días sin ingerir agua y alimento alguno hasta que muere. ¿Se suicidó el manifestante?

2. Las anoréxicas que se rehúsan a comer alimento, ¿se están suicidando lentamente?

3. Los enfermos de cáncer que rechazan un tratamiento de quimioterapia y con ello la única posibilidad de sobrevivir, o por lo menos de alargar sus vidas, ¿están eligiendo una opción suicida?

4. Un atleta de fútbol americano profesional decide retirarse del deporte después de jugar varios años. Meses después muere a causa de severos daños internos en el cerebro como resultado de los constantes golpes que recibió en la cabeza a lo largo de su carrera deportiva. ¿Si el jugador era consciente de las consecuencias de su práctica deportiva, entonces podemos afirmar que se suicidó?

5. Los fumadores empedernidos, los alcohólicos y drogadictos en general, que ingieren de forma frecuente sustancias dañinas que aceleran el deterioro del organismo, ¿podríamos considerarlos como personas suicidas?

6. Una madre decide donar su corazón para dárselo a su hijo quien se encuentra hospitalizado. El trasplante de corazón es un éxito y con ello muere la madre. ¿Estamos ante un auténtico suicidio de la madre? 
7. Un astronauta se ofrece como voluntario para realizar un viaje a los confines del universo con muy remotas posibilidades de retorno a la tierra. ¿ Su decisión de viajar bajo esas condiciones se podría considerar como un suicidio?

8. Un acróbata trapecista de circo se encuentra realizando un espectáculo aéreo ante cientos de espectadores. Durante su acto realiza una serie de movimientos audaces y observamos que antes de culminar su acto no se sujeta del trapecio y cae desde las alturas. Mientras cae se le observa agitar sus brazos y se le oye gritar hasta que golpea contra el suelo fuera de la red de seguridad. Dada la altura y la fuerza del impacto el acróbata muere. ¿Lo que vieron los espectadores fue un suicidio del acróbata?

9. Un joven budista tibetano desea alcanzar el máximo nivel espiritual y para lograrlo decide colocarse en posición de $\mathrm{Om}$ sin ingerir ningún tipo de alimento ni realizar algún tipo de movimiento, pues es requisito necesario estar en un estado perfecto de pureza corporal y mental. Después de un mes y medio de permanecer inamovible muere por inanición. ¿Nuestro joven budista se suicidó?

10. Supongamos que un recluso de una prisión elabora un plan de escape que consiste en lo siguiente: ingerir alguna sustancia o alimento que lo enferme gravemente, de tal forma que la atención médica que se brinda en el reclusorio sea insuficiente para atenderlo, de tal manera que sea llevado a un hospital. Todo esto con la finalidad de estar fuera de la prisión con menos vigilancia y seguridad para escapar. Cuando el prisionero lleva a cabo su plan enferma tan gravemente que muere durante el traslado hacia el hospital. La pregunta es la siguiente, ¿se suicidó el prisionero?

Seguramente, no afirmaríamos que en todos los casos se trata de un suicidio. ¿En cuáles casos podemos afirmar que ocurrió un suicidio? Para dar respuesta a esta pregunta es necesario contar con un mínimo de criterios (por muy simples o vagos que sean estos) que nos permitan saber qué es lo que estamos entendiendo por suicidio. ¿Cuáles son esos criterios? Como hemos visto, se han formulado una amplia variedad de definiciones al respecto que no siempre son compatibles entre sí.

No obstante, en cada una de las definiciones que se han brindado desde la psicología, así como de otras disciplinas, puedo identificar tres elementos esenciales que tomaré como un acuerdo en común de todas que son distintivos y necesarios para referir al suicidio: intencionalidad, conciencia y libertad. Estas tres características son los criterios para determinar e identificar un suicidio de aquel que no lo es.

Me atrevo a decir que la falta de precisión de estas palabras para teorizar ha generado problemas o, mejor dicho, seudoproblemas que han complicado todo en torno al suicidio desde las diferentes aproximaciones en psicología. Demostraré que cuando los psicólogos teorizamos respecto al suicidio con términos del lenguaje ordinario, sin aclarar a qué nos estamos refiriendo, lo único que conseguimos es crear falsos problemas filosóficos y no científicos, pues es común que confundamos las expresiones que hacemos acerca de este comportamiento con las descripciones de su ocurrencia.

A continuación, analizaré por separado el uso que le damos diariamente a estos tres conceptos que están íntimamente ligados, hasta llegar al punto que deseo mostrar. 


\section{Intencionalidad}

Al suicidio se le considera como un comportamiento intencional de quien lo lleva a cabo. No existe algo llamado "suicidio accidental", aun cuando es posible expresarnos de esa forma en algunas muertes. Esta última expresión es un sinsentido pues, de lo contrario, se perdería el uso pertinente de la palabra para hacer una distinción de otras formas de morir. Si el suicidio no fuese intencional se trataría de un error, un asesinato o cualquier otra cosa, menos un suicidio.

Por ejemplo, cuando el piloto automovilista brasileño Ayton Senna da Silva murió en 1994 durante una carrera al impactarse contra un paredón de cemento, la mayoría de la gente se expresó diciendo "murió en un accidente" o "lamentablemente se mató en la carrera". No se decía "murió en un suicidio" o "tristemente se suicidó durante una carrera", porque en estas últimas expresiones está implícita la idea de la intencionalidad del acto. En este contexto las expresiones "se mató" y "se suicidó" no son sinónimos o equivalentes, como cuando se dijo que el actor mexicano "Pedro Infante se mató en un avión que él mismo piloteaba en Mérida". Dicha afirmación no hace alusión a un suicidio sino a un accidente o un evento desafortunado.

Entonces, ¿a qué nos referimos cuando hablamos de la intencionalidad del suicidio? Primero, habría que aclarar qué es eso que llamamos intencionalidad. Cuando hablamos de la intencionalidad, ya sea la nuestra o la de los demás, nos referimos casi siempre al motivo o causa de nuestras acciones. Por ejemplo, decimos "fui al mercado porque mi intención era comprar fruta", "le compraré flores y chocolates a Bárbara porque mi intención es enamorarla", "mi intención es ayudar a los demás, por eso siempre voy al hospital a donar sangre" o simplemente decimos "lo hago porque es mi intención hacerlo". En pocas palabras, hacemos distintas cosas y las llevamos a cabo porque tenemos las intenciones de hacerlo.

Cuando hablamos de las intenciones de suicidarse ocurre exactamente lo mismo. Decimos "Ulises se suicidó porque su intención era terminar con su sufrimiento", "la intención de suicidarme es porque no le encuentro sentido a la vida", "Raúl tiene la intención de suicidarse porque se quiere vengar de sus padres haciéndolos sentir mal", etc.

Por la forma en como nos expresamos de las intenciones de las personas suicidas, así como las confesiones de los propios suicidas acerca de sus intenciones, pareciera que estamos haciendo referencia a tres cosas distintas pero que están vinculadas:

1. A la causa del suicidio. Toda expresión de intencionalidad propone un origen que es responsable de lo que hacemos, por ejemplo, "su intención es suicidarse porque es algo que desea desde hace mucho".

2. A una posesión o pertenencia de la intencionalidad. La intención pasa a ser una propiedad de cada uno de nosotros. Nunca decimos "intención de suicidar" sino "tengo la intención de suicidarme" o "su intención es suicidarse".

3. A una operación de la mente. La intención como una extensión de lo mental, es decir, una acción interna e inobservable previa al acto que se concreta con la ejecución de una conducta en particular. El filósofo Ryle (2002) proporciona un perfecto ejemplo de esta característica de la intencionalidad:

Decir que alguien apretó el gatillo intencionalmente es expresar como mínimo una proposición conjuntiva que afirma el acaecimiento de un acto en el nivel físico y otro en el nivel mental [...] es expresar una proposición causal que afirma que el acto corporal de apretar el gatillo fue el efecto del acto mental de querer apretar el gatillo. (p. 88) 
En realidad, estas tres referencias de la intencionalidad, como causa, posesión y operación mental, no son más que expresiones que nos permiten la comunicación cotidiana y de ninguna manera son descripciones que hagan referencia a una causa, una posesión de algo o a una operación mental que da cuenta o explica el suicidio.

La intención no es la causa por la que nos comportamos ni la razón por la que la gente se suicida. Las personas no se suicidan porque tengan intenciones de suicidarse, así como en el caso contrario, la gente no se suicida por su falta de intenciones. Esto aplica incluso en aquellos casos en que la persona simplemente confiesa "me voy a suicidar porque es mi intención hacerlo". Es decir, cuando expresamos las intenciones de nuestros actos como si éstas fueran las causas por las que hacemos tal o cual cosa, lo que en realidad estamos haciendo en la mayoría de las situaciones es explicitar las acciones que hicimos, hacemos o haremos.

En el ejemplo de "fui al mercado porque mi intención era comprar fruta" la intención no es la causa por la que fui al mercado. Comúnmente voy al mercado porque ya no tengo fruta y pan en mi casa, porque no he comido y tengo hambre, porque quiero gastar mi dinero en alimentos, etc. Ninguno de nosotros vamos al mercado porque la intención nos esté jalando o empujando hacia el mercado. Si digo "esta semana voy a ir al gimnasio porque mi intención es bajar de peso" debe entenderse que la expresión no es una descripción literal. No existe una intención del tipo "bajar de peso" que explique y justifique que vaya al gimnasio. Lo que estoy expresando es que iré al gimnasio para hacer ejercicio con el objetivo de bajar de peso porque me quiero ver estético, por salud, por moda y muchas otras razones, no por mis intenciones.

En el caso del suicidio ocurre lo mismo, si alguien dice "compré veneno porque mi intención es suicidarme" esa persona está explicitando lo que hizo (comprar veneno) y lo que hará (suicidarse), más no está diciendo las causas por las que se suicidará.

Las expresiones anteriores no van más allá de querer decir que lo que se hace es porque se tiene deseos de hacerlo, pero lo deseos no son la causa por la que hacemos las cosas. Los deseos o intenciones no explican nada por sí mismos, por el contrario, esos deseos o intenciones tienen que ser explicados. ¿Cómo se explican? Se empieza por determinar el contexto y la situación en la que se expresa una persona, así como los antecedentes o momentos previos de que brindan un marco de pertinencia y significado de lo que dice.

La intención tampoco es algo que poseamos a manera de esencia al "interior" de nosotros, como si se tratara de un objeto o una propiedad corporal. Cuando decimos "Jaime se cortó las venas de las muñecas con su navaja porque su intención era suicidarse" los posesivos su en esta expresión anterior se refieren a distintas cosas; una hace alusión a un objeto (navaja) y la otra a una tendencia comportamental (intención). Uno es un objeto que se puede poseer, mientras que el otro no es un objeto ni algo susceptible a tenerse. Es obvio que la intención no es del mismo tipo de cosas que cuando digo mi libro (objeto) o su cabello (propiedad corporal).

Si la intención no es un objeto o una propiedad de nuestro cuerpo, ¿entonces por qué nos vemos inducidos a pensar que es algo que poseemos? Esto ocurre por dos razones principales. La primera es por la forma en como hablamos. Dado que siempre acompañamos nuestras expresiones intencionales con los posesivos "mío", "tuyo", "suyo", como si fueran objetos o propiedades, nos vemos inducidos a creer que es algo que nos pertenece a cada uno de nosotros, como cuando decimos "tu perro", "mi casa", "su mano", "nuestras piernas", etc. El lenguaje nos "seduce" a seguir bajo la misma lógica. 
La segunda razón es por la experiencia sensorial o corporal que ocurre en las situaciones particulares en las que tenemos nuestras intenciones. Es obvio que cuando nos comportamos lo hacemos con el cuerpo y no de forma "separada", esto significa que es normal que en casi todas nuestras acciones lleguemos a sentir muchas cosas como alegría, amor, coraje, ansiedad, miedo, y por supuesto, las intenciones de hacer algo. Pero una cosa es que se experimenten esos estados e intenciones, y otra muy diferente que eso que se siente sea en sí mismo lo que estamos refriendo. Es decir, las emociones, sentimientos o sentires en general ${ }^{3}$ que tenemos en el cuerpo son una parte muy importante de nuestro comportamiento, pero no "surgen" independientemente de los objetos o eventos con los que nos relacionamos. Por el contrario, aquello que sentimos y llamamos intenciones tiene existencia como parte constitutiva de las situaciones particulares en las que se desarrolla una interacción conductual.

La intención tampoco es un proceso, estado u operación adicional al comportamiento, es decir, no es un acto de naturaleza mental mediante el cual llevan las ideas a la práctica. Las ideas suicidas no causan el comportamiento suicida, aun cuando es posible tener ideas suicidas previas al suicidio. Siguiendo la argumentación lógica de Ryle (2002), si alguien pensó en suicidarse y se suicidó, no hizo dos cosas distintas. Y mucho menos que la primera, pensar en el suicidio, fue la causa de la segunda, suicidarse.

¿Pero cómo es posible afirmar esto? Nuevamente la gramática del lenguaje nos hace jugarretas. Mencioné en párrafos anteriores que en ocasiones hacemos referencia de la intención como si se tratase de una posesión nuestra, a modo de objetos o propiedades ubicables en espacio y tiempo, pero "misteriosamente" no son susceptibles de verse, olerse o tocarse. Como la intención parece no tener lugar físico, entonces nos vemos en el problema de darle una realidad o existencia invisible. Tradicionalmente, el lugar lógico para otorgarle realidad a la intención es ubicarla adentro de nosotros. ¿Pero en qué parte de adentro de nosotros? En ninguna. Si diseccionamos un cuerpo e inspeccionamos sus partes como el corazón, el cerebro, hígado, cualquiera, no la vamos a encontrar nunca. Obviamente, todos los esfuerzos por encontrar la intención en alguna parte del cuerpo están orientados al fracaso.

Ahora bien, no usamos las palabras intención o intencionalidad únicamente para referirnos a las causas de nuestro comportamiento o de las demás personas. A veces cuando hablamos de las intenciones de alguien nos referimos al carácter de esa persona. Por ejemplo, cuando decimos que "Inés es una persona de buenas intenciones" lo que estamos expresando es que Inés es una persona bondadosa, pues ha hecho acciones que las valoramos socialmente de esa forma. Otras veces, cuando hablamos de intencionalidad, lo hacemos para indicar la elección de una persona, como cuando el aficionado al fútbol comenta "el jugador se dejó caer con toda la intencionalidad en el área grande" se está refiriendo a que la caída del jugador fue una decisión personal para obtener una ventaja y no porque alguien le haya metido el pie o por algún tropezón. También, podemos hablar de las intenciones de alguien para caracterizar una manera particular de relacionarse con las personas, como cuando decimos "Abraham tiene serias intenciones con Verónica" se está haciendo alusión a que Abraham va a entablar una relación de noviazgo o matrimonio con Verónica.

3 Es de conocimiento de todos que existen varias distinciones, filosóficas y psicológicas, entre las emociones, sentimientos y motivaciones. No obstante, aquí los términos los utilizo como sinónimos sólo con el propósito de demostrar mi punto, sin que esto implique necesariamente un error en mi análisis. 
Entonces, si lo anterior es correcto, ¿qué es eso que llamamos intención cuando se trata del suicidio? La intención es una disposición a comportarse y no una acción particular. Por esta razón, no es correcto aplicar criterios de observabilidad y afirmar que las intenciones suicidas pueden verse o no. Las intenciones no son del tipo de acciones como comer, brincar, caminar, etc., que sí podemos observar cuando alguien lo lleva a cabo, aun cuando la intencionalidad de nuestros actos requiere de diversas acciones. Cuando no se ve algo que parece ser una acción pensamos que ocurre en otro plano, en este caso en el plano mental. Tener la intención es realizar determinadas acciones en circunstancias especiales que describen una forma particular en que se lleva a cabo nuestro comportamiento. Decir que alguien tiene la intención de suicidarse no es más que una expresión y no una descripción literal de algún elemento adicional responsable del suicidio.

Con lo dicho hasta ahorita, no pretendo negar que existan personas que desean suicidarse o negar que ocurre algo que llamamos intenciones. Lo que quiero decir es que aquello que llamamos intenciones o deseos de suicidarse no ocurren en un lugar llamado mente, que a su vez se encuentra dentro de nuestra cabeza y es la responsable del acto. Insisto, querer, desear o tener intenciones de suicidarse no son acciones en particular, aun cuando siempre se concreta mediante acciones.

Si queda claro lo anterior, entonces no me extenderé demasiado al hablar de la conciencia en el acto de quien se suicida, ya que requiere exactamente de la misma aclaración. Pero, ¿por qué vincular la intención con la conciencia? Pues porque todo acto de intencionalidad, suicida o no, supone cierto grado de conciencia por parte de quien se comporta, como veremos a continuación.

\section{Conciencia}

La mayoría de los psicólogos, filósofos y, más recientemente, los neurocientíficos, consideran que el estudio de la conciencia es esencial para comprender aquello que nos distingue como seres humanos ${ }^{4}$. La conciencia juega un papel preponderante en el suicidio pues, como la mayoría cree, es el lugar donde se llevan a cabo las ideas, pensamientos o actividades responsables del suicidio.

Cuando decimos en la vida cotidiana que el suicidio es un acto consciente nos referimos a que se hace con conocimiento de causa, es decir, el suicida sabe del resultado de su acción. De lo contrario no diríamos que se trata

$4 \quad$ Algunos científicos sostienen que la conciencia y sus operaciones no son exclusivas del ser humano, por el contrario, animales superiores como el orangután y el delfín también se les puede atribuir estados de conciencia, y en algunos casos extraordinarios de autoconciencia. Las evidencias que apoyan esto, aseguran varios colegas, se pueden observar en diversos estudios interesantes, y bastante debatibles, en donde aparentemente estos animales son capaces de reconocerse frente a un espejo. Este comportamiento sugiere algún tipo de conciencia de sí mismos, esto es, autoconciencia.

Por otro lado, los enormes avances tecnológicos han hecho pensar en la posibilidad de dotar de conciencia a las máquinas en un futuro no muy lejano. La atribución de propiedades de conciencia a las máquinas aún es parte de la ciencia ficción, no obstante, considero que si en algún momento se llegase a sostener tal cosa no podría tratarse del tipo de conciencia mental por las mismas razones que en los humanos no existe tal cosa. 
de un suicidio, sino de una muerte accidental o algo similar ${ }^{5}$. Pero, ¿a qué nos referimos cuando hablamos de la conciencia? La conciencia es, a grandes rasgos, una clase de estados mentales (o cerebrales dirían algunos) que nos atribuimos nosotros los humanos. ¿Qué clase de estados mentales? Los filósofos y psicólogos aún no se ponen de acuerdo, lo cual no es nada raro como veremos más adelante. Sin embargo, coinciden que en el caso del suicidio la conciencia pasa a ser el lugar donde se llevan a cabo las ideaciones suicidas de las que tanto mencionan las teorías psicológicas.

Cuando usamos la palabra conciencia en nuestras expresiones cotidianas le damos diferentes significados en función de la situación. Por ejemplo, cuando alguien pregunta “¿perdiste la conciencia en el accidente automovilístico?” lo que quiere saber es si quien tuvo el accidente veía, oía y sentía lo que estaba ocurriendo o si estaba desmayado. No se refiere a la pérdida de la conciencia como cuando perdemos la cartera o el teléfono celular. No nos fijamos si la conciencia quedó a un lado de la carretera o se fue por el barranco. O bien, cuando una persona le dice a su pareja "no tenía conciencia de que te lastimaba con mis palabras" se refiere a que no veía los efectos emocionales como consecuencia de su discurso. En la expresión "lo hice inconscientemente", generalmente, se quiere decir que se hizo algo sin tomar en cuenta otros factores o que se realizó de manera rutinaria. Un último ejemplo, cuando decimos "eres un conductor muy consciente cuando manejas en carretera" lo que se quiere señalar es una característica de la persona, es decir, que es responsable en su conducir, ya sea porque sigue las indicaciones viales, maneja a la velocidad adecuada, etc.

Es claro que en los ejemplos anteriores se está haciendo referencia a diferentes cosas en función de la situación, y en ninguna de ellas se está refiriendo a una entidad llamada conciencia que "vive adentro" de nosotros. Lo mismo ocurre con expresiones tan comunes como "conciencia colectiva", "conciencia de clase", entre muchas otras.

$5 \quad$ Suicidarse implica conocer su primera consecuencia inmediata, o sea, la muerte de uno mismo. Alcanzar ese conocimiento es posible gracias al uso del lenguaje que permite aquello que comúnmente llamamos conciencia y autoconciencia. El lenguaje nos posibilita a hablar de la muerte de los demás y de la propia, por tanto, también permite que la persona suicida pueda referir su propia muerte con antelación: planificar el día, lugar y forma en que llevará a cabo. En este sentido, solamente los humanos cometemos suicidio en tanto hacemos uso del lenguaje y somos conscientes de sus consecuencias.

Por lo anterior, los animales están imposibilitados de cometer suicido. Es decir, si los animales carecen de lenguaje convencional para referir a eventos como lo hacemos los humanos, entonces están incapacitados de ser conscientes para suicidarse. La comunicación que hay entre animales no es igual al lenguaje convencional que ocurre entre humanos. Quien pretenda identificar comportamiento suicida en los animales debe necesariamente de dotarlos de entendimiento acerca de ideas sociales mediante el uso del lenguaje como instrumento esencial para lograrlo. Sin embargo, es muy difícil de sostenerse tal afirmación.

Alguien podría preguntarse, ¿entonces qué ocurre con las abejas que se "suicidan" protegiendo el panal?, ¿las orcas que se "suicidan" al salir del mar y quedar varadas en las costas? o ¿los lemmings que se arrojan a los precipicios sin razón aparente? Las conductas de estos animales están ligadas a las condiciones biológicas propias de la filogenia de cada especie y a las situaciones medioambientales. No son interacciones mediadas por y como lenguaje convencional. En resumen, cometer suicidio es comportarse lingüísticamente, por consiguiente, suicidarse es algo exclusivo del comportamiento humano. 
Las expresiones de la conciencia en relación al suicidio funcionan de la misma manera: "Emmanuel era plenamente consciente de lo que hacía cuando se pegó un tiro en la cabeza", "después de hacer un examen de conciencia, Paula llegó a la conclusión de que el suicidio era la única opción". Lo que quiero mostrar con todo esto es que la conciencia no es una cosa, estado u operación de la mente que es la causante del suicidio. Ni siquiera es una acción particular que supuestamente ejercemos los humanos racionales. La conciencia simplemente no existe. Si la conciencia no existe, ¿entonces por qué hacemos referencia de ella? Porque la conciencia es una palabra que usamos cotidianamente para caracterizar el comportamiento en diferentes situaciones.

Para aclararlo aún más pensemos en la siguiente situación: supongamos que una joven pareja opta por casarse después de varios años de un noviazgo amoroso e incondicional. Sin embargo, uno de ellos, el hombre, descubre que su amada mujer ha mantenido una relación de infidelidad desde hace varios años con su mejor amigo. Al enterarse de esto, enfurece y se decepciona al respecto. Decide no comentarle nada aún a su pareja porque desea obtener más información y confirmar que realmente se trata de una infidelidad. Investiga y encuentra cosas peores que lo llevan a una severa depresión. Entonces, un día al salir de casa decide no presentarse a trabajar y, en su lugar, decide ir una ferretería a comprar una soga. Después, regresa a su casa donde la ata fuertemente a una viga de la cochera. Opta por ponerse el traje que usó el día de su boda y escribir una pequeña nota que dice "No puedo verte a los ojos y vivir felizmente sabiendo lo que hiciste todos estos años sin decirme nada". Finalmente, se coloca la soga alrededor del cuello y se ahorca mientras sostiene la nota en su mano.

En el ejemplo descrito, ¿el hombre era consciente de sus actos? Seguramente el lector coincidirá conmigo en que sí tenía plena conciencia de todo. ¿Cómo sabemos eso? Nuevamente, el contexto de la situación nos dice si tenía conciencia de lo que hizo o no. Cuando decimos que tenía conciencia no nos referimos a alguna entidad que habitaba en su interior ${ }^{6}$. Es más, en el caso hipotético de que en realidad existiera algo llamado conciencia, es obvio que únicamente tendría relevancia hasta que se lleve a cabo un hecho o acto de aquello que la conciencia elaboró.

En resumen, es importante que queden claros un par de puntos:

1. La palabra de conciencia o consciente es multívoca, por lo tanto, sus expresiones y los distintos usos están en función del contexto, es decir, le damos diferentes sentidos.

2. En ninguna de las expresiones cotidianas se hace referencia a una esencia "consciente" o a una entidad de naturaleza mental adentro de nosotros que sea la responsable de que nos comportemos de tal o cual forma.

Cuando caracterizamos al suicidio como un comportamiento consciente, generalmente, lo que hacemos es decir expresiones y no descripciones literales de lo que ocurre o de las condiciones en que ese ejecuta el suicidio. Los psicólogos hemos creído en la existencia de la conciencia, al igual que las intenciones, como algo adicional o distinto al mismo comportamiento suicida.

$6 \quad$ Es probable que alguien afirme que esta persona tal vez no era consciente porque la depresión no le permitió ver las cosas claras y las posibles soluciones, o incluso, que muy probablemente que debido a que sus niveles de serotonina le ocasionaron un severo malestar anímico que lo privó de ser consciente de lo que hacía. En ambos casos no se alude a una entidad mental, sino a que el hombre no vislumbraba las consecuencias de sus actos o que un estado biológico afectó su conducta, respectivamente. 
Hasta ahora, he caracterizado al suicidio como un acto intencional y consciente, no obstante, considero que hay un último criterio distintivo de este comportamiento. Se trata de la libertad que tiene un individuo para quitarse la vida. Es condición necesaria que una persona goce de total libertad para cometer suicidio, porque esto nos permite diferenciar su comportamiento de otros cuando se trata de poner fin a la propia vida.

\section{Libertad}

El asunto más interesante de la libertad se vincula con el suicidio de una forma muy particular: precisar el grado de responsabilidad moral de la persona que se suicida ${ }^{7}$. Es condición necesaria que todas las acciones del suicida estén libres de determinantes, pues de lo contrario, si fuesen obligadas se trataría probablemente de un homicidio. Es por eso, por lo que la noción de libertad es recurrente en el momento de caracterizar al suicidio, ya que permite especificar las circunstancias en las que se lleva a cabo el acto (Silva, 2003).

Ahora bien, encuentro dos grandes posturas antagónicas en relación con la libertad y el suicidio que impactan de manera importante en las teorías psicológicas. La primera de ellas sostiene que el suicidio ocurre inevitablemente como resultado de una causalidad de factores ajenos a la voluntad o intencionalidad de quien se suicida, por ejemplo, factores tales como las condiciones sociales, morales, económicas, sistemas de creencias, historia familiar, cuestiones genéticas, etc. Esto quiere decir que el suicidio está determinado por diversos factores químicos, biológicos, psicológicos y sociales. Comprometerse con esta postura implica asumir que el suicida no es responsable de sus actos, por el contrario, se le podría considerar como una víctima de las circunstancias. Expresiones como las siguientes pueden adherirse a esta postura: "él no quería suicidarse, pero la situación económica que estaba viviendo era tan difícil que no tuvo otra opción", "ella siempre estuvo en una familia disfuncional llena de violencia y abusos, es obvio que cometiera suicidio", "se suicidó porque no iba soportar la vergüenza por la que pasaría si el mundo se enterara de su secreto", etc. Con los ejemplos anteriores pretendo mostrar el carácter determinista de factores que condicionan el suicidio $^{8}$.

La segunda postura sostiene, contrariamente, que nuestras acciones son producto del ejercicio de libre albedrío, por lo tanto, el suicidio depende en última instancia de nuestras decisiones, más allá de los condicionantes biológicos, sociales, psicológicos, entre otros. Nuestras expresiones que hacen alusión a esta forma de ver el suicidio incluyen, de manera explícita o implícita, la noción "depende de mí” ya que está en función del grado de esfuerzo personal. Aceptar esta postura significa reconocer que las personas suicidas son plenos responsables de dicho acto, independientemente de la circunstancia en la que se encuentren, pues son ellos los que tienen la última decisión.

$7 \quad$ Normalmente hablamos acerca de la libertad de las acciones en animales, no obstante, no los consideramos responsables de sus actos de la misma forma que las personas. Por ejemplo, decimos que los perros corren por el parque con libertad porque les gusta hacerlo. Pero, si llegan a morder a las personas les restamos responsabilidad de ello y culpabilizamos al dueño por no educarlo, por la vida que ha tenido, etc. Esto se debe, entre otras cosas, porque carecen de una naturaleza lingüística que les imposibilita tomar conciencia de lo que hacen.

8 Las implicaciones que trae consigo esta postura van más allá de las personas suicidas, pues lo mismo se podría decir de diferentes comportamientos como las acciones de los asesinos, pedófilos, ladrones, violadores, etc. Es decir, ellos también serían un producto o consecuencia directa de las circunstancias sociales. 
Es obvio que estas dos posturas son totalmente contrarias. Una sostiene que las personas que se suicidan lo hacen porque las circunstancias los obligaron, mientras que la otra afirma que simplemente ejercieron su total libertad. Es como si fuera un "todo o nada". Sin embargo, es posible agregar una tercera postura intermedia o "conciliadora" entre ambas que enuncie que en ocasiones somos libres de elegir y en otras no, o por lo menos en menor grado.

¿Cómo determinar las situaciones en las que somos libres y de cuáles no? En principio, me parece que depende de la propia persona para referir una circunstancia particular como libre de determinantes. Por ejemplo, cuando decimos que alguien "está arrepentido de haberse casado con aquella miserable persona, sin embargo, nadie lo obligó a hacerlo" estamos asumiendo que se estuvo en condición de libertad. Pero, si decimos algo como "me vi forzado a robar comida porque tenía mucha hambre y nadie me daba dinero", queremos decir que el robo está justificado y la acción determinada por nuestras condiciones biológicas y económicas. En este sentido, la libertad es un evento subjetivo de quien lo referencie como tal.

Comprometerse con alguna de estas tres posturas tiene implicaciones importantes, como se observa en las actuales elaboraciones de teorías del suicidio desde la psicología. No obstante, asumir cualquier posición nos lleva a falsos planteamientos, por lo tanto, a varios problemas conceptuales para caracterizar y teorizar sobre el suicidio.

La palabra libertad la aplicamos en diferentes contextos, por lo tanto, posee diferentes usos dependiendo de la situación. Se puede hablar de libertad espiritual, libertad psicológica, libertad de elección, libertad de expresión, libertad jurídica, libertad moral, libertad emocional, etc. (López y Tarasco, 2008; Tomasini, 2004). Voy a explicar a qué se refiere de manera general el término libertad en algunos ámbitos:

Por libertad física, generalmente, nos referimos a una condición externa de la persona y consiste en la presencia o vinculación material que limita las acciones. Por ejemplo, el hombre que está encadenado no posee libertad física pues no puede ir a ningún lado.

La libertad sociológica hace alusión a la autonomía que disfruta un individuo dentro de una sociedad. Esto significa que puede hacer diversas actividades en condiciones donde no haya algún tipo de opresión. Por ejemplo, el típico empleado de una empresa que vive "atado" a sus labores.

La libertad psicológica se ha entendido de dos formas generales. La primera, como la capacidad que tiene el individuo de ser "dueño de sí mismo", es decir, no sentirse obligado a actuar a instancias en las que uno no desea. Y la segunda, a las "libertades internas" tales como los pensamientos, los deseos, la imaginación, etc.

La libertad moral se entiende como la capacidad que tenemos los humanos para actuar en función de un valor de acuerdo con la razón. En este tipo de libertad no hay lugar para dejarse dominar por los impulsos, pasiones e inclinaciones espontáneas. El fin último es que todas las personas se conduzcan por el camino correcto con base en los criterios que determina la sociedad.

Realizar estas distinciones de las libertades no es meramente un ejercicio formal. Más bien, lo que quiero mostrar es que tratan de diferentes sentidos bajo la palabra libertad. No obstante, esto no significa que esta división implique que se contrapongan entre sí. Dado que la libertad no es una cosa, es necesario dar cuenta del contexto en que se está haciendo uso de la palabra para saber si se trata de un hecho bajo una situación condicionante o, por el contrario, se encuentra libre de confinamientos. 
Por un lado, los especialistas en el tema del suicidio, sin importar la disciplina en cuestión, aceptan la diversidad de factores condicionantes que dan como resultado el suicidio. Sin embargo, el médico en su análisis dará más peso a los factores de salud, el psicólogo a los psicológicos, el sociólogo a los sociales, el biólogo a los biológicos y así en cada disciplina. Visto así, en toda circunstancia el hombre se enfrenta a limitantes en su libertad: condiciones biológicas, historia familiar, ideologías, costumbres y los usos que una sociedad impone, etc.

Esta es la visión determinista a la que se adhiere la ciencia para interpretar la realidad. O sea, los fenómenos de la naturaleza están sometidos a leyes universales, desde un grano de arena hasta las gigantescas galaxias del universo. Esto significa que nuestro comportamiento no escapa de dichas leyes universales. Así, es lógico pensar que nuestras elecciones y actos consecuentes no estarán exentos de condicionantes, ni siquiera de la causalidad que acontecen de las necesidades "interiores" (biológicos, deseos, pensamientos, subjetividades, etc.) como las "exteriores" (culturales y sociales). Como si la libertad estuviera dentro de nosotros (de forma subjetiva) o afuera de nosotros (de forma objetiva). Sin embargo, esto se trata de un planteamiento erróneo.

Empecemos con el determinismo que sostiene que todo lo que ocurre tiene una causa, por lo tanto, todo lo que tiene una causa esta predeterminado. Esto quiere decir que todo acontecimiento, incluyendo nuestra conducta, debe de tener una causa. Sin embargo, afirmar que hay determinación absoluta de nuestro comportamiento no quiere decir que se anule la libertad o que esta no exista. Se trata de un problema mal planteado.

Es decir, hablar de la libertad de nuestros actos depende de las especificaciones de la situación en la que uno se comporta. Al preguntarnos si hay libertad para suicidarnos o estamos determinados a hacerlo, la respuesta es clara: tanto la libertad como el determinismo no son objetos o eventos sino constructos impuestos, por lo tanto, estos no pueden tener poder causal o explicativo en el comportamiento general (Smith, 2016).

Es un error pensar que las acciones las hacemos porque somos libres, o bien, porque estamos determinados por diferentes leyes del universo. Depende de la situación en la que se esté llevando a cabo el comportamiento de la persona y el contexto en el que se hace referencia a la libertad. La palabra libertad nos sirve para caracterizar las situaciones particulares en las que nos comportamos y comunicarlas a los demás.

\section{Conclusiones}

Se ha supuesto, en especial entre psicólogos, que la intencionalidad, la conciencia y la libertad tienen su origen como un evento interno, privado y subjetivo en cada uno de nosotros que preceden al acto suicida y, generalmente, lo determina. Desde la psicología, hemos dado teorías acerca del suicidio con base en estas palabras que usamos cotidianamente, asumiendo erróneamente que posee un único significado o que dichas palabras tienen sólo una correspondencia unívoca con referente específico. En términos gramaticales, son correctas nuestras afirmaciones y preguntas acerca de la intencionalidad, la conciencia y la libertad. Pero, son incorrectas en lo que refiere a la relevancia y coherencia de aquello que se afirma o pregunta.

Es probable que, a pesar de las aclaraciones hechas hasta este momento, el lector argumente que lo verdaderamente importante y que nos debería de interesar son los eventos psicológicos en sí mismos, o sea, la intencionalidad, la conciencia y la libertad en el suicidio. No importa la forma en cómo nos expresamos o usamos las 
palabras para referirnos a los fenómenos psicológicos. No tendríamos por qué discutir si es un verbo o no, si tal o cual palabra ya no denota acción alguna, o que si son palabras que tienen una lógica distinta, etc.

Sin embargo, no hay que olvidar que el uso de las palabras diariamente tiene un sentido específico en función del contexto. Esto quiere decir que las palabras están conectadas con nuestras expresiones porque su principal función es la comunicación y, en ese sentido, sólo tienen pertenencia en el contexto presente.

Lo que ocurre en la psicología es que, en la mayoría de las teorías que elaboramos acerca del suicidio, se recurre a ideas como ideación de suicidio, intento de suicidio y suicidio consumado y, por consiguiente, los tratamos como si fueran cosas cualitativamente distintas. Al teorizar mezclamos las palabras que usamos cotidianamente con la intención, conciencia y libertad, como si fueran términos especializados o creados por la misma psicología para dar explicación al comportamiento.

Ni que decir de la infinidad de términos que en psicología mezclamos de forma espuria con las palabras procedentes, por ejemplo, de la medicina como miopía psicológica, autopsia psicológica, muerte subintencionada, dolor de psique, trauma psicológico, etc. Estas expresiones no son más que metáforas que, de forma equivocada usamos desde la psicología como si se trataran de cosas literales, en especial cuando son "explicaciones" del suicidio.

Debo dejar en claro que el problema no está en usar las mismas palabras, sino adherirnos a la misma lógica del discurso de donde las sacamos. No es que se niegue la existencia de la intención, conciencia o libertad de nuestros actos. Más bien, se está cuestionando la forma en cómo nos referimos a ellas y nos inducen a creer que son causas fantasmales que habitan dentro de nuestra cabeza.

Por otro lado, las palabras cotidianas no siempre hacen referencia a un objeto o suceso ubicado en tiempo y espacio en alguna parte de nuestro cuerpo. Este lenguaje ordinario tiene una función comunicativa y no sólo la de dar una etiqueta o nombre a las cosas o eventos (Turbayne, 1974; Wittgenstein, 1956/1997). La separación de las palabras y el mundo con el que nos relacionamos nos lleva a la vieja postura de una realidad independiente de nosotros, es decir, una cosa son todos los eventos que ocurren en el mundo y otra cosa es que las podamos nombrar. Sin embargo, no hay que olvidar que todos los fenómenos de la realidad de los que hablamos, identificamos y estudiamos, son fenómenos de una realidad construida socialmente con base en el lenguaje común u ordinario. Es a partir de este lenguaje que estructuramos y elaboramos todas las interacciones humanas que dotamos de significación como acontecimientos, objetos y eventos que en ella tiene lugar.

Por último, mencionaré que este tipo de análisis conceptual en la psicología es una tarea necesaria para evitar caer en la trampa en la que la mayoría de las teorías psicológicas del suicidio son víctimas; mismas que están orientadas al fracaso al teorizar con palabras que poseen una lógica distinta, sin explicar qué es lo que están entendiendo con cada una de ellas. Es decir, no es posible interpretarlas sin claridad conceptual, sobre todo si se usa la palabra suicidio para su aproximación desde la ciencia sin tener una definición precisa, tal y como veremos en el siguiente capítulo. 


\title{
CAPÍtulo 4
}

\section{Comportamiento suicida: una aproximación desde la Psicología Interconductual}

\author{
Mientras los animales inferiores sólo están en el mundo, \\ el hombre trata de entenderlo; $y$, sobre la base de su inteligencia \\ imperfecta pero perfectible del mundo, el hombre intenta enseñorearse \\ de él para hacerlo más confortable. En este proceso, construye un mundo \\ artificial: ese creciente cuerpo de ideas llamado "ciencia", que puede \\ caracterizarse como conocimiento racional, sistemático, exacto \\ verificable y por consiguiente falible. Por medio de la investigación \\ cientifica, el hombre ha alcanzado una reconstrucción conceptual \\ del mundo que es cada vez más amplia, profunda y exacta.
}

Emile Durkheim

Ningún espíritu, espectro, duende, noúmeno, superstición, trascendentalismo, misticismo, vínculo invisible, creador supremo, ángel, demonio.

Josep Robert Kantor

El propósito de este capítulo es presentar un sistema psicológico que supera las limitaciones de las teorías generales en psicología, así como de aquellas que se especializan en el suicidio. La Psicología Interconductual puede aportar elementos útiles para la descripción, explicación, predicción y control del comportamiento suicida desde un punto de vista científico.

Dado que considero, con base en argumentos históricos y filosóficos, que la psicología es una ciencia, es necesario que explicite de manera general qué es la ciencia, sus propósitos, características y formas de proceder, para después abordar el estudio particular del suicidio desde el sistema psicológico interconductual. 


\section{Antecedente aclaratorio}

La ciencia moderna es una de las revoluciones intelectuales más importantes que ha dado el mundo. Desde sus orígenes en la Antigua Grecia hasta nuestros días se ha transformado radicalmente el pensamiento de la humanidad. Hoy en día, casi ninguna práctica humana ha podido eludir su influencia, ya sea de manera directa o indirecta. De hecho, un indicador de progreso intelectual de cualquier sociedad es la actividad orientada a la práctica científica.

Quisiera empezar este asunto desechando una idea errónea que es común de encontrar en revistas comerciales, libros introductorios y diversos discursos académicos en su intento por divulgar el conocimiento científico. Me refiero a la supuesta existencia de la ciencia, o sea, en singular. Esto es un malentendido bastante frecuente de encontrar. Lo más pertinente y adecuado es hablar de las ciencias, en plural. Esto obedece a dos razones principales:

1. Por el reconocimiento explícito de la variedad de cuerpos teóricos que estudian diferentes aspectos de la realidad como son la física, química, biología, psicología y sociología, principalmente.

2. Porque cada ciencia se rige por su propio objeto de estudio y, por consiguiente, por sus propios conceptos teóricos, preparaciones metodologías ad hoc a sus propósitos, criterios de verificación específicos y explicaciones propias de su nivel analítico.

Claro, todas las ciencias poseen algo en común y es por ello que las identificamos en el corpus científico. ¿Qué es lo que comparten? Todas poseen un interés por el estudio de la naturaleza, esto es, el conjunto de hechos que ocurren como relaciones entre eventos en la realidad. En este sentido, el científico es un naturalista lo que significa dar cuenta del comportamiento de la naturaleza dejando fuera todas aquellas "explicaciones" que hagan alusión a intervenciones divinas o que están más allá de la naturaleza, o sea, eventos sobrenaturales (Bunge, 1989; Chalmers, 1982).

Las ciencias también comparten una serie de pasos de cómo debemos acercarnos a los fenómenos de la naturaleza: por medio de la observación, formulación de hipótesis, diversas etapas de procedimiento y diseños experimentales. En otras palabras, teorizar y experimentar.

Cada ciencia analiza diferentes cualidades y aspectos de la realidad pues persiguen diferentes propósitos de estudio. De hecho, un mismo evento puede ser analizado en distintos niveles científicos. Por ejemplo, pensemos una situación en la que una persona se suicida saltando de un puente. El químico puede precisar la cantidad de elementos químicos, como el cobre, zinc, selenio, molibdeno, flúor, yodo, plomo, vanadio, arsénico, etc., que estuvieron en el cuerpo suicida, para indagar los tipos de reacciones que pudieron ocurrir antes y durante el suicidio. Por otro lado, el biólogo podría determinar las posibles interacciones entre los distintos órganos y su funcionamiento previo al suicidio que favorecieron la consumación del acto. Un psicólogo se enfocaría en el análisis de las interacciones construidas históricamente entre el individuo con su ambiente, y así determinar las condiciones necesarias y suficientes para que la persona se haya suicidado. El sociólogo podría interesarse, por ejemplo, en las implicaciones del suicidio dentro de una sociedad en función de un sistema de valores, creencias y moralidad específica ${ }^{1}$.

$1 \quad$ No menciono las diversas interdisciplinas que estudian el suicidio, pues doy por supuesto que para que surja cualquier interdisciplina es condición necesaria que previamente exista una disciplina sólida. Por ejemplo, un trabajo bioquímico puede investigar los diferentes procesos bioquímicos, como la correlación de ácido 5-hidroxindoleacético (5-HIA) en el líquido cefalorraquídeo, que generalmente están asociados al suicidio. 
Si las distinciones anteriores quedaron claras, entonces por razones de exposición hablaré de "la" ciencia, en singular, en el entendido de que los diferentes cuerpos científicos comparten el mismo pensamiento analítico y lógico general acerca del comportamiento de la naturaleza.

\section{Acerca de la ciencia}

En nuestros días, la ciencia se ha posicionado como el paradigma en el cual pretenden ajustarse diversas esferas disciplinarias tales como la economía, política, pedagogía, historia, sociología, etc. Si bien es cierto que la ciencia no es el conocimiento por excelencia, ni mucho menos es el poseedor de "la verdad", su estatus como forma de conocimiento le ha permitido ganar adeptos cada día. Sus teorías, métodos, explicaciones y derivaciones tecnológicas se han infiltrado rápidamente en casi todos los campos de conocimiento, como en el arte, la medicina, la literatura, los deportes, y en casi todas las actividades de la vida cotidiana.

La pregunta fundamental es: ¿qué es la ciencia? Mucho se ha debatido y realizado diferentes propuestas para mantener una clara distinción entre la ciencia y las demás prácticas humanas (Chalmers, 1982). Algunos científicos y filósofos de la ciencia destacan al método científico como el criterio exclusivo y definitorio para distinguirla de otras prácticas, ya que su forma de proceder le ha permitido obtener un conocimiento que difiere de cualquier otro. ¿Cuál es el método científico? No hay "el" método, por el contrario, lo que hay son "los" métodos, pues son diversas las formas metodológicas que han elaborado para obtener conocimiento científico (Chalmers, 1982; Fereyabend, 1980; Pérez, 1990). No obstante, hay consenso de las condiciones mínimas necesarias para llevarlo a cabo: la observación, la formulación de hipótesis, la experimentación, etc.

Daré la descripción más frecuente y que todo científico estaría de acuerdo de forma general: la ciencia trata del conjunto de conocimientos sistemáticamente estructurados acerca de la realidad, es decir, su orientación está encaminada a la búsqueda de la estructura, operación e interrelación de las cosas y eventos (Kantor, 1978). Esto quiere decir que lo realmente importante son los intereses que persigue la ciencia y no una metodología en específico.

No hay nada inamovible o absoluto en ciencia, nunca se tiene la última palabra en esta práctica humana. Por el contrario, siempre está en constante reconstrucción, es decir, la ciencia se caracteriza por ser un sistema modificable pues no se trata de un dogma como, por ejemplo, el modo de conocimiento religioso. Se trata de un sistema autocorrectivo pues está en constante cambio de teorías y descubrimientos que permiten la formulación de ideas novedosas que dan origen a otras interrogantes. Así, la ciencia se construye mediante y como la teorización y la experimentación. Se experimenta con base a lo que sostiene la teoría actual, y esta última se modifica en función de lo que arroja los experimentos (Díaz-González y Carpio, 1996).

Nada más alejado que caracterizar a la ciencia como un modo de conocimiento que progresa de manera lineal, acumulativa, continua y sin "saltos" cualitativos que nos acerca cada vez más hacia la "verdad". Claro, no podemos ignorar que el movimiento filosófico positivista que representó, por ejemplo, Augusto Comte en su obra Discurso sobre el espíritu positivo fue parte fundamental para caracterizar a la ciencia. Sin embargo, es imposible pasar por alto la concepción kuhntiana acerca del progreso de la ciencia que muestra claramente que se trata de profundas revoluciones en las estructuras científicas en las que no hay cabida la acumulación del conocimiento ni un progreso lineal (Kuhn, 1971). 
Ahora bien, como se mencionó, en las ciencias existen diferentes ámbitos de estudio de la realidad, como la física, la química, la biología, la psicología, la sociología, etc. Estos ámbitos de conocimiento científicos se encuentran relacionados unos con otros. Cada uno de ellos estudia distintos aspectos de la realidad mediante la teorización y experimentación. La actividad de teorizar refiere a la formulación de un conjunto de enunciados y categorías que pretenden establecer orden para organizar la realidad mediante la construcción de un modelo explicativo. Mientras que la experimentación constituye todas aquellas acciones deliberadas que alteran o modifican un objeto o evento con fines analíticos.

Comúnmente, se realiza la experimentación dentro de laboratorios, en especial las ciencias con mayor tradición como la física, química y biología, con la aparatología específica de cada disciplina. Por ejemplo, el físico utiliza balanzas, básculas, espectrómetros de masas, galvanómetros, amperímetros, entre muchos otros. Un químico utiliza tubos de ensayo, termómetros, cristalizadores, matraces Erlenmeyer, pipetas, probetas. Los psicólogos usan pruebas psicométricas, cajas operantes y aparatos en general que miden los cambios fisiológicos de los organismos.

Sin embargo, cuando se habla de experimentación no debe pensarse que todo se realiza en un lugar llamado laboratorio que consiste en una habitación fría, con luz artificial y con aparatos tecnológicos. Se puede experimentar fuera del mismo, es decir, investigación de campo, esto sin que necesariamente se pierda algún tipo de validez. Claro, siempre y cuando el modelo teórico que se utilice lo permita. Las técnicas y procedimientos de laboratorio en psicología son semejantes a los utilizados en la investigación de campo, e incluso cuando se trata de aplicaciones en condiciones sociales. La semejanza radica en la relación funcional básica que se alcanza tanto en el procedimiento de laboratorio como el aplicado. Si bien es cierto que no todos los eventos definidos y descritos en las situaciones que se manipulan y se observan en el laboratorio tienen que ser forzosamente equivalentes a las que se identifican en situaciones sociales con propósitos aplicados, también es cierto que en la práctica hay bastantes resultados efectivos.

Por ejemplo, los psicólogos que deseamos estudiar aquello que denominamos comportamiento prosocial (altruismo, cooperación, competición, etc.), lo podemos estudiar en situaciones de la vida cotidiana y no necesariamente investigarlo en un laboratorio con simuladores computacionales que aparentan una situación como si fuera una situación "natural" con tareas que poco o nada tienen que ver (Carpio, Silva, Pacheco-Lechón, Arroyo, Canales, Morales y Pacheco, 2008; Pacheco-Lechón y Carpio, 2014).

Sin embargo, el estudio experimental de estos comportamientos sociales dentro del laboratorio posee grandes ventajas a diferencia de la investigación de campo, por lo que se requiere un modelo exitoso que permita una fuerte base teórica y metodológica para su generalización (Santoyo y López, 1990). Determinar si se experimenta dentro del laboratorio o fuera de éste depende de los propósitos específicos del objeto disciplinar de cada ciencia en particular. Por ejemplo, los astrónomos no pueden realizar experimentos extrayendo los componentes de las estrellas más lejanas del universo. Pero sí pueden identificar qué materiales componen las estrellas y replicar o manipular con los materiales que se encuentran en nuestro planeta para confirmar sus observaciones estelares.

Por último, voy a recalcar dos aspectos fundamentales acerca de la ciencia. El primero es que el conocimiento científico no es más que una construcción humana, por lo tanto, nada puede ser dado como absoluto y siempre está sujeto a reconstrucciones. Todo lo dicho por la ciencia con respecto a los fenómenos de la naturaleza está en constante cambio. Y el segundo es que no existe en ninguna ciencia una manera particular de desarrollar una teoría, una me- 
todología, una investigación, representaciones de datos, etc. No hay reglas de "oro" para generar conocimiento científico. Lo único cierto es que la ciencia debe de basarse en hechos y no en opiniones. No conoce causas en el sentido absoluto de la palabra. De este modo, la tarea fundamental de la ciencia es la elaboración de principios teóricos con apoyo empírico.

\section{Conductismo radical de Skinner: la ciencia en psicología}

El conductismo es una forma particular de hacer psicología que ha delimitado su objeto de estudio con base en criterios que cumple cualquier ciencia, esto quiere decir que se presenta como una ciencia de lo psicológico (Watson, 1916; Skinner, 1971; 1975; Ribes y López, 1985). Si bien es cierto que al interior del conductismo conviven varias escuelas, todas ellas comparten un rechazo explícito al dualismo mente-cuerpo como el paradigma explicativo del comportamiento de los organismos.

Los principios del condicionamiento operante de Skinner son referencia obligada dentro del conductismo para la explicación del comportamiento psicológico desde una visión científica naturalista de la psicología. El condicionamiento operante consiste en el análisis de las relaciones funcionales que hay entre tres elementos que en conjunto se le ha denominado triple contingencia: estímulo discriminativo, respuesta y estímulo reforzador. Esta triple contingencia es la unidad de análisis que explica el comportamiento simple y complejo de los organismos.

El suicidio visto desde el condicionamiento operante puede ser explicado como una conducta de escape, esto es, la emisión de una respuesta que se encuentran bajo el control de estímulos llamados aversivos. Los estímulos aversivos son aquellos objetos o eventos que comúnmente identificamos como "desagradables" y que rechazamos cuando tenemos contacto con ellos. La conducta de escape describe la situación en que un organismo tiene contacto con un estímulo aversivo, entonces el organismo emite una de respuesta que irrumpe el contacto con dicho estímulo. Un par de ejemplos de la vida cotidiana ilustrará esto mucho mejor: cuando estamos viendo una película en nuestra casa y de pronto comienza a oírse demasiado ruido proveniente de la calle (estímulo aversivo), decidimos cerrar las ventanas (respuesta de escape) para poder disfrutar la película. Otro ejemplo es cuando alguien que está bajo el abrasador sol que hay en Mexicali (estímulo aversivo), decide ocultarse bajo un techo o una sombra (respuesta de escape) para refrescarse.

En ambos casos, el estímulo aversivo se convierte en un refuerzo negativo condicionado, es decir, la conducta de escape aumenta la probabilidad de emisión de esa clase de respuesta. El término "negativo" señala que el efecto de fortalecimiento ocurre porque esa clase de respuesta lleva a la eliminación del contacto con un estímulo aversivo, por lo tanto, existe una mayor probabilidad de la frecuencia de su ocurrencia en situaciones similares.

En el caso del suicidio, la conducta de escape ocurre, por ejemplo, cuando un hombre recibe regaños de su jefe en el trabajo (estímulo aversivo), constantes llamadas del banco amenazando con embargar su casa (estímulo aversivo), quejas diarias por parte de su esposa (estímulo aversivo), etc., y para terminar con estos problemas que lo deprimen todos los días opta por tomar una pistola y dispararse en la cabeza (respuesta de escape). En palabras de Sidman (1989), el suicidio es una conducta de "escape final" en términos del condicionamiento operante.

Sin embargo, esta explicación derivada de los principios del condicionamiento operante tiene varios problemas de orden conceptual y causal para el comportamiento suicida. El principal de ellos tiene que ver con el necesario 
refuerzo de la respuesta que ocurre cuando se da término al estímulo aversivo, ya que sólo es posible en la medida en que se vuelva a presentar una situación similar y aumente la probabilidad de frecuencia de esa respuesta de escape, cosa que es imposible en el caso del suicidio, por obvias razones. Por eso, Skinner (1971) en su obra Ciencia y conducta humana considera que en la mayoría de los casos de suicidio se trataría de un complejo comportamiento de autocontrol:

El suicidio es otra forma de autocontrol. Evidentemente, nadie se suicida debido a que, en ocasiones anteriores, haya escapado de una situación agresiva haciendo lo mismo. Como ya hemos visto, el suicidio no es un tipo de conducta al que se puede aplicar la noción de frecuencia de respuesta. Si se produce, los componentes de la conducta deben haber sido intensificados por separado, a no ser que esto suceda bajo circunstancias en las que la frecuencia sea un dato obtenible, no podremos asegurar, con propiedad, de un hombre concreto que "es probable o improbable que se suicide" — como tampoco puede nadie decirlo de sí mismo-. Algunos casos de suicidio, aunque desde luego no en todos, siguen el precepto de cortarse la mano antes de que ésta sea motivo de escándalo, el espía apresado por el enemigo puede utilizar este método para evitar la divulgación de secretos de Estado. (p. 227)

En este último ejemplo de suicidio que menciona Skinner se puede interpretar como una conducta de evitación, que al igual que la conducta de escape, se encuentra bajo control de estímulos aversivos. No obstante, en la conducta de evitación la respuesta impide o pospone la presentación de un estímulo aversivo, o bien, si es inevitable su presentación la respuesta reducirá la "intensidad" del estímulo aversivo. Siguiendo el ejemplo del espía que ofrece Skinner, la respuesta de evitación ocurre cuando éste se corta la mano, y el estímulo aversivo, que aún no se presenta, será la llegada del enemigo.

La conducta de evitación tiene el mismo problema que la conducta de escape: si el suicidio es una clase de respuesta operante significa que necesariamente la respuesta que se emite tiene como consecuencia funcional producir un estímulo reforzador que incremente la probabilidad de esa clase de respuesta suicida. Obvio esto no es posible. Ya sea conducta de escape o evitación, no se produce ningún reforzador ni se fortalece ninguna clase de respuesta suicida.

Pero, ¿qué hay del suicidio como conducta de autocontrol que menciona Skinner? Las conductas de autocontrol, tales como llevarse la mano a la boca para guardar silencio y no soltar una carcajada, o cuando rechazamos cierto tipo de comida para continuar con una dieta, la respuesta que autocontrola el comportamiento tiene la función de evitar las consecuencias negativamente reforzantes de la respuesta. ¿Cómo se logra este autocontrol? El medio ambiente social proporciona, en principio, las consecuencias reforzantes o aversivas que, posteriormente, la propia persona será quien produzca las condiciones de estímulo para el autocontrol de su conducta. Así, en el caso del suicidio es la propia persona quien genera las condiciones de estímulo para llevarlo a cabo. No obstante, esto significa que para que una persona despliegue un comportamiento suicida autocontrolado es necesario que haya sido reforzada por otros en este tipo de conducta, por lo tanto, no puede ser una conducta autocontrolada.

Un problema adicional está relacionado con la complejidad del comportamiento, pues desde el condicionamiento operante todas las respuestas son vistas como iguales en términos funcionales. Es decir, da igual suicidarse con 
un tiro en la cabeza para evitar una dolencia corporal muy severa, que suicidarse como consecuencia de una serie de reflexiones racionales. Esto es así porque en el sistema operante el criterio definitorio siempre es la obtención de un reforzador independientemente de todas las actividades previas del organismo (Skinner, 1979).

Por último, existe un severo problema en lo que refiere a la historia de reforzamiento (historia psicológica) en la explicación operante. La historia de reforzamiento no forma parte de las conexiones necesarias de la triple contingencia, por lo tanto, queda lógicamente fuera de cualquier explicación dentro del sistema. En este sentido, es incorrecto afirmar que las personas se suicidan por su historia psicológica, pues nos veríamos obligados a inventar "acción a distancia" que expliquen la conducta suicida y el comportamiento general (Ribes, 1982).

Dicho lo anterior, procederé a describir el sistema psicológico que supera las limitaciones conceptuales, lógicas y teóricas del conductismo skinnereano ${ }^{2}$ y que está en condiciones de estudiar los fenómenos psicológicos de una forma coherente y sistemática, entre ellos el suicidio.

\section{Sobre el Interconductismo}

La Psicología Interconductual es propuesta por Jacob Robert Kantor (1924) que concreta en un modelo específico para el objeto de estudio de los fenómenos psicológicos de carácter científico. En este sentido, la psicología interconductual cumple con los siguientes lineamientos y características generales que conforman las actuales teorías científicas:

1. Es homogénea con las demás ciencias. La ciencia no trata con un mundo distinto del físico, es decir, con cosas que están "más allá" o algo que está oculto en la naturaleza. Una ciencia psicológica como la interconductual se aproxima a los fenómenos a través de la medición y su representación temporal-espacial. Esta característica es típica de una ciencia natural pues permite la congruencia con las ciencias limítrofes a la psicología, o sea, la biología y la sociología.

2. Es una ciencia autónoma, más no independiente. La psicología forma parte del llamado corpus científico junto a la física, química, biología y sociología, primordialmente. Esto significa que hay una continuidad de los eventos de la naturaleza entre estas ciencias, por lo tanto, los progresos que tienen las demás ciencias impactan en la psicología como forma de conocimiento. Sin embargo, es autónoma al interior de la disciplina en la medida en que no es dependiente de los avances de otras ciencias para estudiar los fenómenos que le corresponden, ya que se rige por sus propios, conceptos, teorías, metodologías y criterios de verificación. Esto permite estructurar lógicamente a los eventos psicológicos en un nivel específico de la realidad en armonía con las demás ciencias.

3. Se constituye a partir de un modelo de campo. El estudio de lo psicológico a partir de un modelo de campo como el interconductual supone varias ventajas respecto a las aproximaciones tradicionales. Una de ellas es que genera explicaciones más coherentes y naturalistas que aquellas simplistas de causalidad mecánica o que

$2 \quad$ A pesar de la gran cantidad de críticas que ha recibido el conductismo de Skinner, es necesario mencionar que gran parte de las acusaciones hechas tanto al sistema operante como al conductismo en general, no son válidas. Más bien, la mayoría de las supuestas críticas surgen por la incomprensión del sistema, como aquellas realizadas por Noam Chomsky (1984). 
se fundamentan en algún tipo de esencialismo en los objetos que "causan" la conducta. De igual manera, supera a aquellas explicaciones que hacen inferencias fantásticas de lo que conjeturan ocurre "dentro" del organismo. Un modelo de campo como el interconductual pone de manifiesto la organización funcional de todos los elementos participantes de un segmento psicológico, o sea, pone énfasis en el sistema de interdependencia entre los elementos participantes en el fenómeno psicológico. Esto nos aleja de los supuestos determinantes (internos o externos) aislados del comportamiento y nos encamina al análisis funcional de cada elemento con base en los demás que participan.

La psicología interconductual constituye una ciencia natural que se ocupa del estudio de la conducta entendida como interacción construida del organismo con su ambiente, es decir, lo psicológico es la relación funcional entre las acciones de los organismos y aspectos específicos del medio (Kantor, 1924). El interés está en la interacción misma y no en las acciones que hace un organismo o en la actividad ambiental.

Algunos de los supuestos básicos generales en la explicación y descripción de los eventos psicológicos que se asumen desde el interconductismo son los siguientes (Kantor, 1978; Ribes y López, 1985):

a. Los eventos psicológicos consisten en campos multifactoriales, es decir, todos los factores participan sincrónicamente.

b. Lo psicológico constituye un nivel específico que articula el conocimiento científico que no es reductible a lo biológico ni a lo social. En todo caso, la psicología es el puente entre las ciencias biológicas y las sociales.

c. Los eventos psicológicos suponen la participación de los organismos de manera total con su ambiente, y no sólo la participación de algunos órganos o tejidos específicos.

d. La conducta posee una historicidad que se manifiesta como cambios en la ontogenia de cada organismo singular sin importar la especie. La historicidad psicológica difiere de la biológica (entendida como evolución filogenética) y de la social (formaciones socioeconómicas transformadas).

e. La conducta, interacción entre organismo y ambiente, puede ocurrir en formas cualitativas que se expresan en diferentes niveles de organización de lo psicológico.

El modelo de campo interconductual es una propuesta original dentro de la psicología y su investigación, pues, entre otras cosas, propone la afectación recíproca entre diferentes elementos que constituyen el campo. No debe confundirse con la afectación de elementos que sostienen en otras psicologías y que constantemente sus conceptos violentan una lógica de campo. El modelo interconductual permite estudiar los fenómenos psicológicos como eventos molares y moleculares complejos. Pero, ¿cómo está constituido el modelo de campo? Se contemplan los siguientes factores en el evento psicológico (EP):

- Función de respuesta ( $f r)$ : corresponde a la actividad o acciones del organismo.

- Función de estímulo (fe): es aquella actividad del objeto de estímulo.

- Historia interconductual (hi): es una disposición de los individuos para interactuar en el presente con base en las formas y modos de comportamiento en el pasado, es decir, son los segmentos conductuales previos a la interacción presente. En otras palabras, la historia de las interacciones es la historia psicológica. 
- Factores disposicionales (ed): refiere a las circunstancias que influyen de manera indirecta en la relación de la fr y la fe. Los factores pueden ser ambientales tales como la temperatura, la luz, la presencia de otros organismos, etc. Y, también, pueden ser organísmicos como la enfermedad, la saciedad, el agotamiento, entre otros.

- Medio de contacto $(m d)$ : hace alusión a las condiciones necesarias y suficientes que posibilitan que un determinado tipo de interacción ocurra.

- Límite de campo: es la delimitación de los eventos de la interacción en la que participa el organismo, es decir, todos aquellos elementos que integran la interacción.

Todos estos factores se relacionan de forma sincrónica (simultánea) y no diacrónicamente (sucesivos o encadenados) ya que es un sistema de interdependencias. Tal y como lo menciona Hayes (1994):

Desde el punto de vista interconductual, el campo psicológico es un campo unificado, un todo interactivo. No es causado desde dentro, lo que significaría que el campo se causa a sí mismo. No es causado desde afuera, pues no hay fuera. El campo no es causado. Simplemente es. (p. 115)

Kantor (1978) resume el modelo de campo en la siguiente ecuación en donde representa el sistema de interacción completo $(\mathrm{C})$ y la unicidad del campo interconductual (k): $\mathrm{EP}=\mathrm{C}$ ( $\mathrm{k}$, fe, fr, hi, ed, md). Todos los factores que conforman el modelo del campo se esquematizan en la figura 12.

Este campo interconductual es la representación conceptual de un segmento particular en el continuo conductual como sistema de relaciones recíprocas. Este segmento representa lo psicológico, es decir, todos los elementos participantes que en su totalidad dan como resultado aquello que denominamos fenómeno psicológico. Lo que se aprecia en la figura 12 es un "corte" en el continuo espacio y tiempo que hacemos deliberadamente los psicólogos con fines analíticos. A partir de este segmento conductual podemos determinar cuándo la persona empieza a construir psicológicamente de forma particular. En el caso que nos interesa se trata de la construcción histórica que va constituyendo el comportamiento suicida.

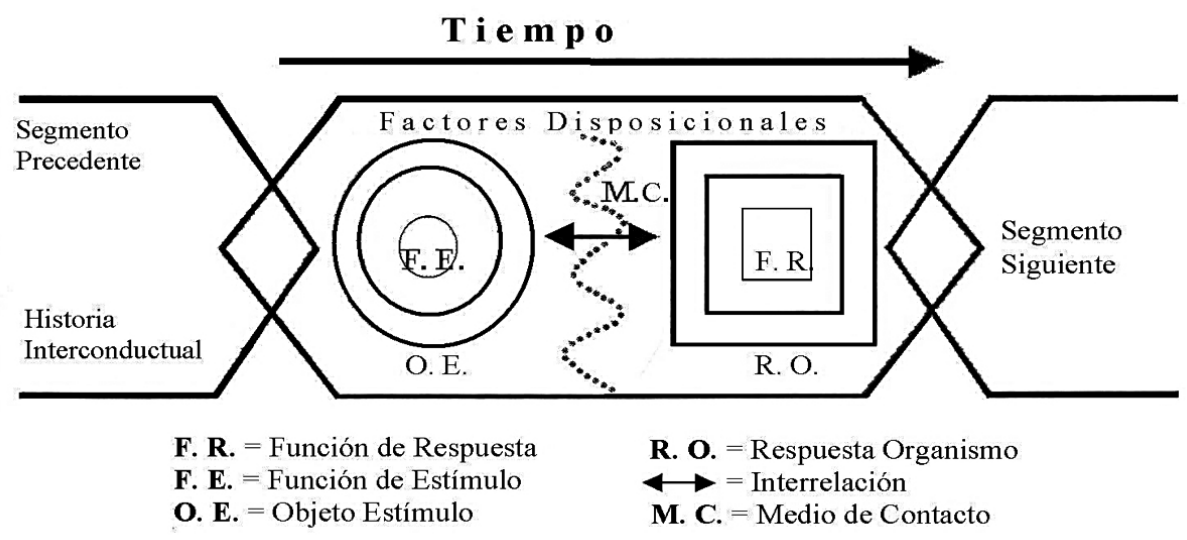

Figura 12. Segmento interconductual. 
En resumen, lo psicológico desde esta perspectiva se da como la construcción de relaciones entre el organismo y su ambiente, por lo tanto, la historicidad psicológica siempre está anclada al comportamiento individual, aun en aquellos casos en los que se estudian las interacciones entre pares o análisis de grupos. Así, puede afirmarse que la historicidad psicológica inicia desde el momento que un organismo responde a objetos estímulo de forma no reactiva ligadas biológicamente (por ejemplo, las denominadas asociaciones de estímulos) y culmina con la muerte del organismo.

Es importante dejar en claro algo que seguramente el lector se habrá dado cuenta, pero no sobra hacerlo explícito: la propuesta interconductual no es una teoría o modelo psicológico particular del suicidio, por consiguiente, no debe pensarse que la investigación que se realice a partir de este modelo generará una aportación a las múltiples teorías suicidas ya establecidas. Más bien, el modelo interconductual es un marco general en el que es posible integrar los diversos comportamientos psicológicos, incluyendo aquellas que se relacionan con el suicidio, para el análisis amplio que permita la vinculación con otras formas de comportamiento.

Aclaro que la mayoría de las personas creen que una teoría especializada en el suicidio es superior y provee numerosas ventajas respecto de aquellas teorías que describen el comportamiento general. Sin embargo, esto es un error muy común que más adelante haré ver.

\section{Evolución de la interconducta psicológica}

Desde el interconductismo se reconoce las diferencias cualitativas que existen entre las diversas interacciones psicológicas de los organismos. Por ello, con base en los planteamientos que Kantor elaboró, Ribes y López (1985) propusieron una taxonomía funcional que integra criterios teóricos y metodológicos para el estudio científico de las interacciones psicológicas de diferente complejidad. Dicha taxonomía describe distintas formas de interacciones que permite organizar el comportamiento psicológico general y específico de una manera coherente, sistemática, inclusiva y progresiva en su complejidad.

Existen por lo menos cuatro conceptos que son fundamentales en la propuesta taxonómica ya que son las que permiten reconocer diferentes tipos de organización funcional: función, contingencia, mediación y desligamiento funcional ${ }^{3}$.

Por función se entiende a aquel segmento inseparable de estímulo y respuesta. El estímulo es una manifestación de propiedades de los objetos y sólo es tal cuando hace contacto con la respuesta de un organismo en un medio de contacto determinado. Las diferentes funciones estímulo-respuesta son formas de comportamiento de afectación recíproca que pueden estructurarse en distintos niveles de complejidad.

La contingencia refiere a la condicionalidad o dependencia recíproca de los elementos que conforman la función. Así, desde este punto de vista, la conducta se concibe en términos de campos contingenciales que implica la interacción del organismo, los objetos estímulo y eventos particulares del ambiente en un determinado medio de con-

3 Para familiarizarse con algunos términos técnicos que se utilizan en la obra de Ribes y López (1985), el lector deberá remitirse a la obra original Teoría de la conducta: Un análisis de campo y paramétrico. Sugiero que aquellos que nunca han tenido contacto con dicha propuesta, lean antes la obra Conceptos básicos del interconductismo (Varela, 2009), esto con el fin de alcanzar una mayor comprensión de la taxonomía funcional. 
tacto fisicoquímico, ecológico y/o normativo convencional, que posibilita la ocurrencia de las funciones psicológicas (Maximus, 2002; Ribes y López, 1985; Varela, 2009).

La mediación describe el proceso mediante el cual un elemento llamado mediador del campo interactivo es crítico en la estructuración de las relaciones entre los diferentes elementos que participan en una interacción particular. Al respecto Ribes (1990) menciona:

La mediación describe relaciones complejas, interdependientes y sincrónicas. No hay un sólo factor 'causante’ de la relación. Existen factores que establecen las condiciones para la interacción y factores que se interrelacionan. La búsqueda de relaciones mediadas consiste en identificar factores críticos que permitan tener en cuenta diferentes clases de organización de tales interacciones. (p. 153)

Por otro lado, el desligamiento funcional se refiere al grado de autonomía conductual del individuo respecto a las circunstancias situacionales presentes con las que interactúa. El concepto de desligamiento funcional es fundamental porque permite la distinción entre la interconducta estrictamente biológica de la psicológica. También posibilita identificar las diferencias cualitativas entre los tipos de comportamiento psicológico. Por ejemplo, llorar cuando nos entra algún objeto extraño al ojo (conducta biológica) es cualitativamente diferente que cuando lloramos al recordar a un ser querido difunto (conducta biológica y psicológica). O bien, en el caso del suicidio, no es lo mismo aquel que termina con su vida para evitar ser asesinado por alguien, que quitarse la vida por una creencia religiosa.

Ahora bien, ¿cuáles son esos niveles? Los distintos tipos de interacciones se puntualizan como cinco niveles funcionales ${ }^{4}$ a saber: Contextual, Suplementario, Selector, Sustitutivo Referencial y Sustitutivo no Referencial (Ribes y López, 1985). Describiré cada nivel funcional y un ejemplo de comportamiento psicológico de la vida cotidiana. Dicho ejemplo no implica necesariamente la culminación de un comportamiento suicida, más adelante aclararé las razones de esto:

- Función Contextual. Esta función, o forma de interacción, psicológica es la más simple y en su estructura no incluye ninguna otra forma previa de organización psicológica. Consiste en la interacción entre el organismo y el ambiente que es mediada por dos segmentos estimativos, esto quiere decir que la relación de un estímulo con la actividad del organismo depende de la contextualización de otros estímulos. La actividad del organismo se ajusta a la ocurrencia de los eventos sin alterarlos. Por ejemplo, cuando una persona se deprime al ver en la televisión un programa que le recuerda a una persona difunta muy querida.

- Función Suplementaria. Esta forma de interacción se caracteriza principalmente porque la actividad del organismo altera las relaciones de contingencia, es decir, alterar el medio. Se forma por la mediación de una función contextual entre eventos de estímulo por parte de la respuesta del organismo, es decir, la respuesta del organismo modifica una relación entre estímulos. Siguiendo el ejemplo anterior, esto ocurre cuando la

$4 \quad$ No incluyo los cambios conceptuales y teóricos realizados en los últimos años de las funciones sustitutivas pues considero que dichos cambios, realizados por los autores originales y otros tantos colaboradoes, han entorpecido su conceptualización, así como la coherencia y lógica al interior de la taxonomía (Ortega y Patrón, en preparación). 
persona al ver el programa de televisión opta por apagar el aparato y, con ello, cambiar la situación, en este caso para evitar seguir llorando.

- Función Selectora. En este nivel interactivo existe una diferenciabilidad de respuestas del organismo frente a las relaciones ambientales que cambian constantemente. Esto es, que la actividad de un individuo está en función de la selección del evento estímulo. Un ejemplo sería cuando una persona es capaz de modificar el comportamiento de otra persona en diferentes situaciones cambiantes, como el estado de ánimo de una persona que se encuentra triste, otras veces en melancolía, otras más enojada, etc.

- Función Sustitutiva Referencial. En este nivel funcional de interacción un individuo puede responder en la situación presente en términos de una situación temporal (pasado o futuro) y/o espacial (lugar distante), o bien, a las características no aparentes físicamente en la situación presente. Se requiere que el individuo disponga de un sistema reactivo convencional, es decir, lenguaje. Por lo tanto, esta forma de interacción es típica del comportamiento humano. Es una interacción que necesita de dos momentos de respuesta que, en algunos casos, puede ocurrir en un solo individuo. En estas interacciones las respuestas convencionales de individuo, denominado referidor, media la relación (referente) no presentes o no aparentes al comportamiento de otro individuo, llamado referido.

Una forma de comportamiento en este nivel funcional tiene lugar, por ejemplo, cuando una persona que pretende suicidarse (referidor) le explicita a su pareja (referido) las razones por las que el suicidio es la mejor opción para morir (referente). Y a su vez, su pareja realiza un discurso (referido) con el objetivo de persuadirlo de esos pensamientos suicidas (referente) que tiene la persona con intenciones de suicidarse (referidor).

- Función Sustitutiva no Referencial. En este nivel se pierde la sustitución de contingencias a partir de un evento concreto: el referente. El proceso de mediación de contingencias es independiente de los eventos concretos presentes, es decir, la relación se da como mediación de relaciones entre productos lingüísticos sin atender a las propiedades situacionales. Por ejemplo, cuando una persona habla o escribe para ella el sentido de su vida y su absurdo, sin que aquello tenga un referente concreto. En este caso, la persona se habla o elabora un escrito sobre eventos que sólo se pueden identificar como productos convencionales que no tienen una ubicación de tiempo y espacio concreto.

Cada uno de estos niveles funcionales interactivos poseen al interior de su estructura diferentes subcasos que describen y conforman diferentes formas de comportamiento. No son interacciones a modo de "etapas de la vida" como la infancia, adolescencia, madurez y vejez. Tampoco son estadios de desarrollo análogos a teoría psicogenética de Piaget. Por ejemplo, sería incorrecto suponer que un individuo se encuentra en una etapa contextual en los primeros años de vida y en la adultez en una sustitutiva no referencial.

Estos cinco niveles funcionales deben entenderse como una clasificación y caracterización del comportamiento psicológico que ofrece un marco general para el estudio de los eventos psicológicos de forma ordenada, sistemática y coherente. Dichos niveles funcionales están organizados de forma progresivamente más compleja e inclusiva, esto quiere decir que, en una función suplementaria, por ejemplo, se incluye al interior de su estructura una función contextual que modifica cualitativamente a la función suplementaria. 
Por otro lado, los niveles funcionales mencionados requieren de criterios que estructuren los episodios interactivos a las demandas específicas de cada situación (Carpio, 1994; Ribes, 1998). Entonces, tenemos cinco criterios de ajuste funcional correspondientes a los requerimientos conductuales de cada nivel funcional, los cuales pueden ser impuestos por otros o por el mismo individuo, de manera tácita o explícita. Los criterios de ajuste que se describe son los siguientes:

- Ajustividad: En este criterio se demanda un ajuste de la respuesta, en términos de los parámetros de tiempo y espacio de los eventos de estímulo. La respuesta del organismo se ajusta a las relaciones entre estímulos sin poder alterarlas.

- Efectividad: Se demanda la adecuación temporal, espacial, morfológica, de duración e intensidad de la respuesta del organismo, de tal forma que regula o modifica la distribución en tiempo y espacio de los eventos de estímulo.

- Pertinencia: Se requiere de la variabilidad efectiva de la respuesta y sus propiedades en función de la variabilidad del ambiente y sus condiciones. Esto quiere decir que la respuesta efectiva debe de ajustarse al evento estímulo que cambia de momento a momento. Por lo tanto, la respuesta debe ser pertinente situacionalmente a las contingencias que son distintas en cada situación.

- Congruencia: Se demanda que la reactividad del individuo se independice de la morfología de las propiedades fisicoquímicas y de los parámetros tiempo y espacio de la situación presente. La congruencia se refiere a la correspondencia de contingencias referidas lingüísticamente y las situacionales efectivas en tiempo y espacio presente. Este tipo de ajuste es exclusivo de aquellos organismos que desplieguen comportamiento lingüístico.

- Coherencia: En este tipo de criterio se demanda que el individuo ajuste su actividad a las contingencias que se establecen entre productos lingüísticos que son abstraídos de las situaciones concretas y se organizan como correspondencias entre "decires" y, por lo tanto, como una forma de "hacer".

¿Cómo se relacionan los niveles funcionales y los criterios de ajuste? Los criterios de ajuste son de naturaleza psicológica, es decir, permiten delimitar las características funcionales de las interacciones psicológicas de cada uno de los niveles funcionales (Carpio, 1994).

Entonces, de acuerdo con lo anterior, las interacciones pueden ser cualitativamente distintas en las relaciones entre las acciones del organismo y los eventos del ambiente. La interacción psicológica implica al individuo comportándose, ya sea reaccionando sensorialmente, hablando, escribiendo, etc., con relación a otros objetos en determinada circunstancia.

A partir de esta taxonomía y los criterios de ajuste es posible estudiar distintos fenómenos psicológicos de diferente complejidad funcional, que van desde las discriminaciones simples que hace casi cualquier organismo hasta interacciones de complejidad mayor como leer y escribir. Las interacciones más complejas (sustitutivas referenciales y no referenciales) son típicas de la conducta humana y marca una distinción con la conducta típica animal. De hecho, el comportamiento humano se caracteriza, entre otras cosas, por desarrollarse en ambientes convencionales que surgen como prácticas de la vida diaria entre individuos. Estos ambientes convencionales están íntimamente ligados a los contextos lingüísticos y es a partir de este contexto que los individuos pueden participar no sólo en situaciones que se 
restringen a los eventos del aquí y ahora, sino que es posible independizarse de los aspectos meramente situacionales, por ejemplo, cuando le platicamos o escribimos a alguien acerca de los planes que tenemos para nuestras próximas vacaciones, de algo que ya ocurrió o de algo que está ocurriendo pero no es aparente o manifiesto, por ejemplo, cuando se habla de la belleza de ser madre, del orgullo de la nación mexicana o de la pérdida del sentido de la vida.

La psicología interconductual cumple con los criterios de una buena teoría de acuerdo con lo propuesto por Kuhn (1982). Es un sistema que está en condiciones de estudiar las interacciones suicidas y responder las interrogantes que han quedado como misterios sin resolver o con respuestas poco coherentes. Por ejemplo, ¿por qué hay personas que cometen suicidio en situaciones que aparentemente no ameritan tal comportamiento? Pensemos en aquellas personas que cometen suicidio por "golpes de amor", tal como ocurre con los adolescentes que dan por terminado una relación de pareja de unos cuantos meses. Mientras que hay otros adolescentes que vivieron meses en campos de concentración durante la Segunda Guerra Mundial y nunca intentaron suicidarse.

\section{Metas de la psicología interconductual}

En ciencia, dar cuenta de la naturaleza de los fenómenos es fundamental. ¿En qué consiste ese "dar cuenta" de los fenómenos psicológicos? Si la psicología, como la he esbozado a partir de la propuesta de Kantor, es la ciencia que estudia la construcción de las relaciones ontogenéticas de un organismo con su ambiente en un determinado medio de contacto, entonces algunas de sus metas son la descripción, explicación, predicción y control de dichas interacciones para la construcción de teorías (Bueno, 2011). Examinemos con mayor detalle cada una de estas metas.

Descripción. La descripción tiene que ver con el cómo ocurren las cosas. Describir implica definir e identificar el fenómeno que se pretende estudiar, sus características y componentes, así como determinar las condiciones específicas y generales en las que ocurre. Para el estudio del comportamiento suicida se tiene que describir las acciones del individuo (morfologías de las respuestas) ante los objetos estímulo con los que entra en contacto, además de los factores del segmento conductual que permiten la ocurrencia funcional estímulo-respuesta (lugar, situación social, personas participantes, etc.), para así dar cuenta de la interacción psicológica total. Los métodos comúnmente usados para describir un fenómeno en psicología son los registros del tipo anecdótico, ocurrencia continua, temporal, entre otros.

A pesar de que describir los fenómenos es parte indispensable de toda teoría científica no se agota tan sólo con eso la labor en ciencia. No es suficiente con hacer descripciones detalladas de los fenómenos pues también debemos explicar los fenómenos.

Explicación. Es necesario saber por qué los hechos ocurren de una manera y no de otra. La explicación es una de las operaciones esenciales de la ciencia y tiene que ver con el por qué ocurren las cosas. Es un proceso teórico-empírico para determinar las causas de los fenómenos de la naturaleza. En este sentido, la explicación representa la prueba empírica que postula la teoría, es decir, es la evidencia que confirma lo que sostiene la teoría. Determinar las causas de los fenómenos nos remite a eventos multifactoriales sincrónicos y no necesariamente a procesos mecánicos o diacrónicos, aun cuando cotidianamente explicamos de forma sucesiva los acontecimientos.

De hecho, se puede afirmar que la ciencia es fundamentalmente explicativa pues intenta expresar la forma en cómo se relacionan unos hechos con otros en términos de leyes y principios. Explicar en psicología es poner en manifiesto la relación que hay entre los elementos que participan en la construcción histórica particular de un indivi- 
duo en una situación determinada. En el caso del suicidio habría que relacionar los objetos, personas y eventos, que conforman la interacción completa, y determinar cuál es el papel funcional que desempeña de cada uno de ellos en la situación específica conforme a las relaciones construidas de forma única e irrepetible de una persona.

Sin embargo, no todas las explicaciones de cada una de las psicologías coinciden. Desde el interconductismo, la causalidad Aristotélica es la que da cuenta de los fenómenos psicológicos: causa material (mediador de la contingencia), causa formal (nivel funcional), causa eficiente (parámetros y propiedades de la relación organismo-objeto estímulo) y causa final (criterio de ajuste psicológico). Cada una de estas causas en conjunto sería la explicación psicológica.

Tanto la descripción como la explicación son objetivos fundamentales de la ciencia. Sin embargo, la descripción y explicación son refutables si no se lleva la posibilidad de la predicción y control del fenómeno. De hecho, toda explicación que tenga éxito acarrea inmediatamente a la posibilidad de predecir y controlar.

Predicción. La predicción es un rasgo fundamental de la cientificidad de una teoría. Claro que predecir un evento de la naturaleza no es algo exclusivo de la ciencia, por el contrario, todas las personas hacemos predicciones de casi cualquier cosa; qué equipo ganará las elecciones presidenciales, qué día lloverá, cuáles serán los números de la lotería y muchas cosas más. La humanidad a través de la historia ha procurado conocer el futuro, predecir los acontecimientos y prepararse para hacerles frente antes de que ocurran. En la antigüedad, los oráculos y adivinos eran muy respetados y estimados, pues se les atribuía la capacidad sobrenatural de revelar el futuro a través de la interpretación de los signos de los dioses.

En nuestros días, se tiene una mayor confianza en la ciencia para elaborar predicciones precisas. Predecir en ciencia se refiere a explicitar las consecuencias que se observan y que se espera que ocurran. La capacidad para predecir consecuencias específicas y de forma exacta, en tiempo y espacio, ofrece la posibilidad de hallar evidencia que apoye o contradiga una teoría (Popper, 1983).

Pero, ¿cuál es la diferencia entre las predicciones científicas y aquellas que surgen de la vida diaria? La diferencia radica en que las predicciones de la ciencia se formulan a partir de un modelo abstracto que permite anticipar la ocurrencia no solamente de aquellos fenómenos con los que hemos tenido contacto directo. Por ejemplo, es posible predecir los cambios que sufrirá el universo con el paso del tiempo, cuál será la conducta de un político después de descubrirle sus fraudes, etc. Casi cualquier ser humano predice la conducta de seres humanos y animales. La mayor parte de las veces, nuestras predicciones son razonablemente correctas y tienen sentido, pues si no fuera posible hacer predicciones con precisión sobre la conducta de los demás, entonces las sociedades humanas no podrían existir.

Teóricamente, es posible predecir cuando alguien está a punto de suicidarse. Sin embargo, en la vida cotidiana no ocurre la mayor parte de las veces. Aún no es posible predecir con exactitud gran parte de los suicidios. Por ello, los psicólogos nos apoyamos en perfiles suicidas que elaboramos con base en las características típicas de los suicidas y de aquellos que lo han intentado. Uno de los principales fines de estos perfiles es identificar y anticipar el acto suicida en aquellos individuos con esta tendencia, para después explicar cómo se construye esta forma de comportamiento.

Sin embargo, hay que decir que, si bien son bastante útiles los perfiles, estos no son suficientes para alcanzar la predicción perfecta. ¿Cómo se podría hacer una predicción más precisa? La mejor forma de hacer una predicción con un alto grado de éxito es mediante el control de las variables de interés en un fenómeno. 
Control. Entre las finalidades de toda ciencia está el control de los fenómenos naturales. El control, necesariamente, es una clase de predicción y trata acerca de la manipulación de aquellas condiciones en las que se ha observado el fenómeno de interés para provocar cierto resultado. No sólo eso, esta manipulación de las condiciones y sus efectos son la evidencia empírica y verificación de lo que la teoría explica. Se puede afirmar que el control es el siguiente paso natural para alcanzar un mayor conocimiento. El control de una interacción psicológica permite comprender los límites de la teoría y, por lo tanto, del comportamiento que estudiamos.

Todas las ciencias buscan el control de los fenómenos, por ejemplo, el físico atómico modifica la estructura de alguna partícula determinada para corroborar sus hipótesis. El químico reproduce, altera y, en ocasiones, mata a un ser vivo para observar efectos. El biólogo puede provocar reacciones orgánicas como los reflejos a ciertas partes de un animal u organismo para investigar acerca del sistema nervioso, endócrino, muscular, etc. El psicólogo puede programar la presentación y retiro de objetos estímulos (variando la frecuencia y su temporalidad) con base en el comportamiento de un organismo para el análisis del aprendizaje o el desarrollo de habilidades y competencias.

En área de investigación psicológica no existen estudios experimentales enfocados a cumplir la meta de controlar el comportamiento suicida, o sea, en promover dicha conducta con fines científicos. No me refiero al control como prevención del suicidio que, si bien es una forma de controlar el comportamiento, poco ha servido en el caso del suicidio como mostraré más adelante. Más bien me refiero a la reproducción o réplica de las condiciones en que ocurre el suicidio con el fin de comprobar nuestras hipótesis de variables.

En resumen, dar cuenta de estas metas en conjunto daría la causalidad de los fenómenos psicológicos. No obstante, estas metas no son significativas sólo para la psicología interconductual, por el contrario, se comparten con las demás ciencias en la actividad de investigación básica y aplicada. Son metas inclusivas, es decir, cada una de ellas incluye a las otras de forma gradual. Esto es, que para llegar al control del fenómeno psicológico necesariamente se tiene que hacer una descripción, explicación y predicción del evento. Aludir a ellos por separado nos daría como resultado una visión parcial del fenómeno psicológico.

Es muy probable que alguien sostenga que son otras las metas en la psicología interconductual (Hayes, 1994) y la ciencia en general. O que algunas de las que mencioné ya no se pretenden en pleno siglo XXI. Otros dirán que continúo en la lógica de un pensamiento positivista ya superado ${ }^{5}$, etc. No obstante, considero que estas metas siguen siendo vigentes y mínimamente necesarias en la ciencia de hoy, incluso aun cuando se les cambia de nombre, se agreguen metas o se les transforme en su proceder. La ciencia y, por consiguiente, la psicología interconductual, sigue haciendo su quehacer científico como descripción, explicación, predicción y control de los fenómenos de la naturaleza.

$5 \quad$ Discrepo de manera parcial de aquella idea que sostiene que la predicción y control, metas de la ciencia, obedecen a los intereses ideológicos de la clase burguesa para su servicio. O bien, que la predicción y el control de los fenómenos persiguen objetivos pragmáticos para juzgar el éxito de una teoría (Morris, Todd, y Midgley, 1993). Sin duda, el positivismo de Comte fue influenciado por diversas instituciones sociales que guardaban los intereses de la burguesía. No obstante, no hay que olvidar que la ciencia nace en la antigua Grecia bajo un sistema ideológico-político alejado del actual capitalismo y la lucha de clases sociales. 


\section{El control del comportamiento suicida}

El término "control" hace alusión a diferentes cosas dependiendo del contexto. Por ejemplo, podemos hablar del control que ejerce un gobierno sobre los ciudadanos, del control que ejercen nuestros familiares sobre nuestras decisiones, del control de natalidad de un país, del control de una epidemia o enfermedad, del control de una especie como parte de su preservación, mantener el control en una situación estresante, etc.

¿Qué significa "control” en el ámbito de la ciencia psicológica? Controlar, en este contexto, significa replicar las condiciones para la ocurrencia de un fenómeno con interés teórico. A medida que conocemos los factores que influyen en el comportamiento general de los individuos nos vemos en la necesidad de ir más allá de la mera descripción, explicación y predicción: debemos buscar el control. Como ya mencioné, todo investigador en psicología se interesa por un fenómeno conductual, sin importar la teoría psicológica que se trate. Su principal interés gira en torno a averiguar las condiciones en que se produce dicho fenómeno.

Ejercer control sobre lo que uno observa en la naturaleza es un proceso esencial en la ciencia, de lo contrario, no se podría tener la certeza de los factores que influyen y transforman un fenómeno conductual. Así, las variables no controladas permanecerán siempre en explicaciones potencialmente alternas. En este sentido, puedo afirmar con toda seguridad que es totalmente legítimo, con fines de investigación científica, el control deliberado del suicidio en otros para alcanzar un mayor entendimiento del fenómeno. Controlar, y no solamente predecir, cualquier fenómeno conductual de forma exitosa es un indicador de comprensión de lo que ocurre, y el comportamiento suicida no es la excepción. La mejor forma de demostrar el entendimiento del suicidio es logrando su control.

A menudo se discute si se debe o no controlar la conducta humana, si es ético o no, si es posible o imposible, etc. Sin embargo, le pregunto al lector, ¿acaso existe alguna actividad en la que seamos libres del algún control? En realidad, independientemente de los argumentos a favor, en contra o de cualquier opinión, nuestra conducta diariamente es controlada. Pensemos en quienes diseñan los comerciales para la televisión, radio, periódicos, internet y todo tipo de medios con fines publicitarios. Todos ellos realizan diversas estrategias para influir en la forma en que nos comportamos.

Por ejemplo, el mercado de la industria del vestido se encarga de influir en millones de consumidores a través de distintos medios para la compra de ropa específica. Los partidos políticos nos atiborran de todo tipo de publicidad para que los ciudadanos votemos por ellos. Incluso, hasta en las actividades más comunes recibimos castigos o premios por nuestras acciones, que constituyen una de tantas formas de control del comportamiento: los padres controlan la conducta de sus hijos, los maestros la de sus alumnos, el jefe la de sus empleados y el gobierno la de los ciudadanos. El control se puede ejercer de muchas formas y no necesariamente implica un "mal" o algo negativo. La capacidad de influir en la conducta de otros y poder manipularla abre el panorama a una multitud de probabilidades de mejoramiento social como las relaciones de trabajo, la enseñanza en la educación, convivencia familiar y de la comunidad, etc.

El control en psicología involucra emprender una acción con el fin de que otros actúen en cierta forma, o sea, de la modificación del comportamiento. Hacer algo o dejar de hacerlo produce control y efectos en la conducta de otros de manera recíproca. 
En resumen, se siguen haciendo numerosos estudios, modificaciones a las teorías, elaboración de otras tantas nuevas, que intentan explicar el suicidio y, a pesar del esfuerzo de académicos e investigadores, el número de suicidios aumenta y se vuelve cada vez más difícil predecir cuándo alguien se suicidará. La ciencia se encarga de elaborar descripciones, explicaciones y predicciones acerca del suicidio, no obstante, es necesario controlar experimentalmente el suicidio, pues es el paso siguiente de todo modo de conocimiento científico: la manipulación de esta forma de comportamiento para alcanzar una mayor comprensión.

Sin embargo, existen dos principales dificultades para llevar a cabo el control en el comportamiento suicida. El primero de ellos surge al interior de la ciencia y tiene que ver con los aspectos metodológicos para realizar experimentos de esta forma de comportamiento. Por ejemplo, la posibilidad de replicar los efectos en un mismo individuo, la variación de parámetros con un grupo control y grupo experimental, etc.

La segunda dificultad se relaciona con las cuestiones políticas y morales en la experimentación con humanos. El problema radica en los límites morales que conciernen a cada persona. Rebasar o romper esos límites implica para algunos faltar al respeto, transgredir y violentar la dignidad de cada persona. Sin embargo, como es sabido por todos, la ciencia no es neutral respecto a otras instituciones vigentes. Si queremos ir más allá de los márgenes de nuestros tiempos, debemos hacer lo que sea necesario, prescindiendo de la moral convencional.

\section{Sobre el suicidio como interconducta}

La palabra suicidio proviene del lenguaje coloquial y de ninguna manera está diseñada con fines científicos para su teorización. Si es correcto esto, entonces lo primero que debemos hacer es ofrecer una definición de suicidio para la psicología con el propósito de determinar el tipo de hechos que nos proponemos a estudiar bajo esa palabra. Con esto no pretendo operacionalizar ${ }^{6}$ el concepto a un modo único de comportamiento, sino ofrecer un concepto lo suficientemente abstracto que permita abarcar el fenómeno en formas de conductas similares.

Propongo conceptualizar al suicidio desde la psicología como un comportamiento efectivo y afectivo que se caracteriza por terminar el continuo conductual del mismo individuo que se desempeña. Es efectivo porque cumple con un criterio de logro, o sea, con los requerimientos para satisfacer el cumplimiento como campo de contingencias, en este caso es suicidarse. Esto significa que para entender cómo alguien logra alcanzar esta efectividad es necesario remitirse a las condiciones históricas interactivas particulares de quien se suicida, objetos, lugares y personas que han formado parte de las interacciones, de los factores biológicos intervinientes, etc.

El comportamiento suicida también es afectivo ${ }^{7}$ porque altera su propio sistema contingencial individual. El suicidio siempre implica la alteración del sistema contingencial individual de quien se comporta, pues es una condición necesaria y única de este comportamiento. Sin embargo, en términos psicológicos, el suicidio también puede

6 Operacionalizar significa "bajar" los conceptos de un nivel de abstracción a un nivel empírico para la manipulación de estos referentes.

$7 \quad$ Al utilizar este término no me refiero a las afectividades motivacionales o emocionales. Más bien, debe entenderse en el sentido aristotélico, o sea, como afección. En este sentido, la afección transforma mediante una acción un evento u objeto. 
ocurrir como una contingencia compartida en la medida en que modifique el sistema contingencial de otro individuo. Por ejemplo, cuando un adolescente se suicida altera o, mejor dicho, termina con su sistema contingencial y al mismo tiempo altera el sistema contingencial de otro, como puede ser el comportamiento de los padres.

En resumen, el suicidio se conforma como la construcción de relaciones interactivas que culminan con un acto concreto que da por terminado el "flujo" conductual de quien se comporta. Por tanto, se trata de un comportamiento efectivo y afectivo cuyo cumplimiento de criterio de logro implica necesariamente dar por concluida la historicidad psicológica. Siempre ocurre como un cambio en sistema contingencial individual y este puede, en ocasiones, llegar a alterar el sistema contingencial de otros.

\section{Las emociones en el comportamiento suicida}

Ahora bien, ¿qué pasa con los estados emocionales que tanto relatan los suicidas? Las emociones desempeñan un papel primordial en las teorías suicidas, como las teorías de Beck (1979) y Linehan (1993), pues en la gran mayoría de éstas señalan como responsables del comportamiento suicida a los diferentes aspectos emocionales. De hecho, si uno parte del sentido común, las emociones parecen ser las auténticas razones de que la gente cometa suicidio. La gente explica el suicido con expresiones como "se suicidó porque era una persona depresiva", "lo hizo porque la tristeza que sentía era profunda", "tuvo un arranque de celos que lo hizo suicidarse", "la noticia lo llevó a la desesperanza y por consiguiente cometió suicidio".

Estas expresiones de la vox populi no son muy distintas de lo que se sostiene desde algunas perspectivas psicológicas. Por ejemplo, Schneidman, Faberow y Litman (1970) atribuyen como causa principal del suicidio al dolor emocional, o como ellos lo denominan, psicalgia. Ésta resulta ser, de acuerdo con estos autores, el detonador y verdadero causante del suicidio pues, como es sabido por todos, la mayoría de los suicidas expresan diversos estados emocionales y sentires como si estos fueran las causas de sus actos.

Antes de seguir con la importantísima relación que hay entre las emociones y el suicidio es necesario que le aclare al lector varias cosas a fin de evitar cualquier tipo de confusión que frecuentemente cometemos en la psicología.

Lo primero que hay que aclarar es que el panorama teórico de las emociones en la psicología presenta muchas dificultades teóricas y conceptuales (Plutchik, 2001). No hay un acuerdo respecto a qué es la emoción, por lo tanto, algunos lo abordan como un fenómeno social, otros como algo subjetivo, biológico, intencional o todas las anteriores. Tampoco hay diferencias claras unánimes entre la emoción, los sentimientos, los estados de ánimo y las motivaciones. Sin embargo, hoy existe un sinfín de clasificaciones en la psicología acerca de tipos de emociones tradicionales y otras tantas "descubiertas" (por ejemplo, básicas-complejas, positivas-negativas, universales-singulares, con funciones comunicativas y con funciones evolutivas). Dado que la mayoría de los teóricos no puede dar una definición que incluya todas las propuestas, porque todo es caótico, prefieren elaborar una conceptualización amplia y ambigua.

Incluso, si un día se llegara a un acuerdo sobre qué son las emociones y cuáles son, nos enfrentaríamos a otros problemas: si las teorías del suicidio explican la naturaleza de las emociones, ya que supuestamente es la principal causa de este comportamiento, entonces no tendría sentido elaborar de forma adicional teorías acerca de las emociones. O bien, de forma contraria, si las emociones son la causa y explicación del suicidio, entonces mejor abandonamos las teorías suicidas y nos concentramos en aquellas que tratan a las emociones como objeto de estudio. 
Ahora bien, alguien podría preguntarse cuál es el problema de tener dos teorías, una del suicidio y otra de las emociones. Podría pensar que es mucho mejor tener dos teorías especializadas que se integren para dar una explicación completa. Sin embargo, esto es erróneo en muchos sentidos y conlleva a muchos problemas. Crear dos teorías a partir de distintos postulados implica que cada una de éstas elabore conceptos especializados bajo diferentes lógicas, por lo tanto, se vuelve imposible ofrecer explicaciones que armonicen entre las dos.

En el siglo XXI, la postura dominante de las emociones es aquella que se apega al conocimiento de las neurociencias. A las emociones se le ha conferido un carácter eminentemente fisiológico, como las respuestas glandulares, musculares y diferentes reacciones orgánicas que están relacionadas con la actividad cerebral. Pero, como ya he dicho, para la psicología es inapropiada una explicación enteramente biológica, pues todo se reduciría a reacciones organísmicas y actividad refleja.

Es obvio que las emociones tienen necesariamente una dimensión biológica, por lo tanto, los órganos tienen un papel importante en aquello que experimentamos en términos emocionales. De hecho, es posible controlar diferentes emociones con el uso de fármacos, como las pastillas para la ansiedad o medicamentos para la depresión, que inhiben o alteran las funciones de órganos específicos. Esto nos ha hecho pensar que los estados emocionales se encuentran en nuestro cuerpo en forma de sustancias o de forma "psicológica" adentro de órganos particulares. Nuevamente, desde la psicología esto es un planteamiento erróneo. Lo único que se está haciendo es confundir una condición necesaria (biológica) con la interacción total (organismo biológico con el ambiente) para la ocurrencia de los episodios emocionales. Esto es un reduccionismo psicológico que ni siquiera un biólogo moderno se atrevería a sostener, o sea, es un sinsentido afirmar que las emociones están en el cuerpo.

Entonces, ¿cómo debemos entender a las emociones y su relación con el suicidio? Las emociones, desde la perspectiva psicológica interconductual, se consideran como factores disposicionales del tipo organísmico que forman parte de las interacciones conductuales. Es decir, son parte de las circunstancias que influyen de manera indirecta en la relación conductual. Es claro que las emociones constituyen una serie de respuestas biológicas como la sudoración de las manos, la boca seca, excitación sexual, lágrimas de ojos, elevación de la temperatura en la cara, etc. No obstante, las diferencias entre las respuestas biológicas y las psicológicas radica en que las primeras se tratan de reacciones reflejas y las segundas son construcciones históricas que están vinculadas al ambiente y un organismo en particular. Las emociones tienen las características de ocurrir en un tiempo de corta duración y de forma abrupta, en la mayoría de los casos, y no son causa ni consecuencia de nada. Es una disposición a comportarse en función de la situación.

En resumen, desde el interconductismo, las emociones no son eventos que se dan en el organismo, sino que se dan como la relación entre la actividad biológica y los objetos o eventos con los que se tiene contacto. Nunca nos comportamos en el vacío, no somos independientes de las situaciones. Las emociones, como respuestas biológicas abruptas, modulan las interacciones psicológicas actuales y que facilitarán o entorpecerán las interacciones posteriores. En el caso del suicidio, las emociones son aquellos eventos que experimentamos fisiológicamente, que por su intensidad y singularidad se reportan como las causas de las ideas autodestructivas. 


\section{Intentos suicidas}

Se ha documentado de manera frecuente que las personas suicidas realizan diversos intentos previos al acto consumado, pues al parecer no todos lo logran en el primer intento. Esto ha llevado a los expertos a interpretar estas acciones inefectivas como signos de auxilio o avisos para llamar la atención del suicida. Esto hace pensar que no se trata de genuinos deseos de morir, la persona aún no ha decidido suicidarse.

Hagamos una lectura distinta de estos intentos suicidas. Partamos de las siguientes preguntas: ¿por qué fallan?, ¿acaso no lo planean bien?, ¿en verdad es tan difícil cometer suicidio? En términos operativos o mecánicos es mucho más difícil, por ejemplo, pegarle a una pelota de béisbol o encestar una canasta en básquetbol desde una distancia considerable que cometer suicidio mediante un ahorcamiento. De hecho, si alguien desea suicidarse cuenta con un sinfín de formas simples y complejas para lograrlo. Entonces, ¿por qué hay gente que acumula intentos de suicidio sin lograrlo?

Dado que el suicidio siempre ocurre siempre a nivel conductual, es pertinente preguntarse acerca de las condiciones que se necesitan para cometer suicidio. Es claro que el comportamiento suicida, a diferencia del resto de las interacciones psicológicas, no se le puede caracterizar como un desempeño competente o hábil, ya que un buen suicidio no es el que se intenta muchas veces. Esta característica única del suicidio amerita realizar un análisis distinto a las visiones tradicionales. Desde el interconductismo, los intentos fallidos pueden interpretarse de tres formas principales:

1. Comportamiento inefectivo: Este refiere a la falta de habilidades conductuales necesarias para llevar a cabo el suicidio. Algunos intentos de suicidio pueden ser vistos como comportamientos de nula efectividad, pues el individuo despliega conductas estereotipadas sin resultados. Pensemos en aquella persona que pretende suicidarse al cortarse las venas de las muñecas en la bañera de su casa. Si hace esto en estado de reposo, puede tardar mucho en desangrarse, aun cuando los cortes en los antebrazos alcancen las venas y arterias más delgadas, por tanto, le espera una larga y tortuosa agonía. Si esta persona es "rescatada" y en momentos posteriores el suicida decide volverlo a intentar de la misma forma sin tener éxito, entonces estamos ante un comportamiento inefectivo porque no logra el suicidio, además de intentarlo en un lugar inapropiado en el que es posible que siempre haya alguien presente para impedirlo.

2. Cumplimiento de un criterio de logro distinto al suicidio. Es posible que varios de los intentos de suicidio no sean más que la satisfacción de cumplimiento de criterios de logro que tienen forma de suicidio para un tercer observador, pero que en realidad cumplen con otro criterio de logro que es impuesto por quien pretende suicidarse. ¿Qué quiero decir con esto? El comportamiento psicológico siempre ocurre como un ajuste interactivo (criterio de ajuste psicológicos) y este se apega a distintos requerimientos de actividad conductual (criterio de logro). Los criterios de logro son requerimientos conductuales, que a su vez implica un tipo de ajuste funcional (criterio de ajuste psicológico), que imponen las personas o uno mismo.

Entonces, los intentos de suicidio en ocasiones forman parte de un criterio de ajuste que el mismo suicida se impone para generar respuestas conductuales de otros individuos y alteran el sistema contingencial del supuesto suicida. Dicho en términos coloquiales, lo que pretende es llamar la atención y no la muerte en sí misma. Siguiendo el ejemplo de la persona que se corta las venas, si lo sigue haciendo de la misma forma o 
alguna similar, es porque esa forma de morir da el tiempo suficiente para que alguien llegue a detenerlo y le ponga atención. Incluso, si no llegara nadie le da tiempo al propio suicida de curarse para intentarlo de nuevo en una situación que permita la intromisión de otra persona.

3. Comportamiento exploratorio. Los intentos suicidas fallidos también pueden tratarse de comportamientos del tipo exploratorio, es decir, de conductas variadas que pretenden aproximarse al suicidio sin llegar a tal. Una persona puede realizar diferentes acciones como cortarse alguna parte del cuerpo sin poner en total riesgo la vida, como provocarse un leve envenenamiento o experimentar cualquier otra situación en la que exista una autolesión que no se magnifique. Las sensaciones que el suicida experimenta le permiten anticiparse, ya sea para planear su suicidio o para cambiar de opinión de lo que va a hacer. Estos contactos funcionales le permiten al individuo tener un punto de referencia para la mediación de sus conductas futuras. Claro, pudiera darse el caso de un comportamiento exploratorio suicida que termine de forma accidental en la muerte como algunas muertes infantiles (Acevedo, 2015; Fernández, 2017). Se trata de una muerte accidental y no de un auténtico suicidio pues, como ya había dicho en otra parte, el suicidio accidental no existe, ya que es condición necesaria un elemento de "intencionalidad" de la persona para llevarlo a cabo.

\section{Comportamiento suicida infantil}

El suicidio no es un asunto exclusivo de una edad en especial, se da en personas de la tercera edad, adultos, adolescentes y, lamentablemente, también en niños. Para adentrarnos al suicidio infantil es necesario mencionar las dos principales formas en que se relaciona la niñez con conductas autodestructivas. Una de ellas tiene que ver con los eventos negativos o sucesos aversivos que ocurrieron durante la etapa infantil y que de alguna forma sus consecuencias se manifiestan en años posteriores en diferentes formas, entre ellas el suicidio. Esto se expresa en afirmaciones como "aquellos que durante la infancia fueron maltratados o sufrieron de abusos físicos y psicológicos no tienen otra alternativa que hacer una represión masiva y disociación de emociones que detonan en la vida adulta" o "las semillas del suicidio están en la infancia, por tanto, todo acto autodestructivo tiene su origen en los primeros años de vida" (Acevedo, 2015).

Estas afirmaciones psicológicas, que claramente son metáforas, explican el suicidio infantil como un proceso en el que ocurre un "salto" en tiempo y espacio en la historia interactiva de las personas. Desde la psicología interconductual, a esto se le denomina como "causalidad a distancia" o, bien, a forma de burla, "contacto fantasmal". Se trata de un evento aislado en un momento de nuestra vida que "regresa" y explica por qué hacemos tal o cual cosa.

Por otro lado, diversos psicólogos alejados de una visión científica o médica optan por formular "explicaciones integrales" mediante el eclecticismo teórico y metodológico. Por ejemplo, si alguien sufrió de abusos o eventos violentos en la niñez es probable que se generan todo tipo de emociones y recuerdos que supuestamente se "guardan" en la memoria del cuerpo, esto es, en algún órgano, tejido o extremidad corporal. Muestra de esto, de acuerdo con los teóricos, son las diversas enfermedades psicosomáticas. Dado que conciben al cuerpo como si fuera una "unidad de almacenamiento", los seudopsicólogos centran sus esfuerzos por trabajar con los aspectos corporales bajo el nombre de terapia alternativa. 
Todas estas afirmaciones y creencias ameritan de varias precisiones. Por un lado, pareciera que cuando alguien es maltratado durante la niñez tendrá consecuencias graves que perdurarán toda la vida ya que esas experiencias se guardan (en algún lugar y de alguna forma) en nuestros cuerpos y pensamientos. Sin embargo, esto es falso y es un intento de excusa para justificar nuestros actos. Es falso porque la historia psicológica facilita o interfiere determinados comportamientos en una situación presente, pero de ninguna manera es el determinante de nuestros actos. Y, por otro lado, también sirve de excusa para que la gente responsabilice de sus actos a otras personas o a cualquier cosa, asumiéndose como víctima.

Pero, curiosamente, cuando se tratan de eventos exitosos o de beneficio, las propias personas se atribuyen como responsables absolutos de dichos logros. Claro que uno nunca se comporta al margen de las experiencias pasadas, sobre todo si se tratan de situaciones difíciles y de gran intensidad. Sin embargo, las consecuencias que forman parte de la tendencia conductual presente son moduladas a las interacciones presentes y posteriores.

Respecto al supuesto almacén corporal de los eventos del pasado o de las emociones vividas, todo esto es una confusión. Para afirmar tal cosa es necesario dar cuenta de dónde se guarda todo, cómo, cuándo, en qué cantidad y qué tipo de eventos. Además, claro está, de explicar cómo recuperamos esos eventos del pasado y por qué se "pierden" en ocasiones. Todo es una metáfora. No se almacena ni se guarda nada en ninguna parte del cuerpo, ni siquiera en el cerebro como la mayoría cree. Desde hace siglos, hasta hoy en día, se sigue debatiendo el lugar donde supuestamente se guardan los recuerdos, emociones y un sinfín de fenómenos psicológicos en el cerebro. Es normal que aún no se haya encontrado "el archivero" o "la habitación", se encuentra de forma temporal todo lo que guardamos ya que se trata de eventos relacionales y no de cosas que sean susceptibles de almacenarse como si depositáramos objetos en cajas. Aquellos que sostienen que los recuerdos se guardan y se reproducen para nosotros en el hemisferio derecho del cerebro, habría que darles un bisturí y un cerebro para que lo examinen con detalle y nos digan cuántos recuerdos le caben y de qué tipo.

Una lectura más coherente a la tradicional es aquella que postula cómo las interacciones psicológicas modulan diferentes estados biológicos sin necesidad de una entidad oculta que media lo fisiológico con lo ambiental. Las situaciones contingenciales en las que se comporta un individuo forman parte indisociable de los cambios fisiológicos. Creer que las vivencias violentas de cualquier tipo durante la niñez han sido almacenadas de alguna forma en el cuerpo, permaneciendo ocultas hasta que un evento de la vida adulta la detona para dirigirla hacia otros o contra sí mismo, es un sinsentido.

Los sucesos desafortunados durante la niñez no son los responsables de los suicidios de las personas. De hecho, en la psicología interconductual es incorrecto y contraproducente teorizar con palabras como "niñez", "infantil", "adolescente", "adolescencia", "adultez" y "adulto". Ni que decir de palabras como "edad mental" o "madurez psicológica”. Estas expresiones son adecuadas en la vida cotidiana pues nos permiten comunicarnos, no obstante, para una ciencia como la psicología se requiere de un lenguaje especializado y preciso.

Por ejemplo, algunos sostienen que aquellos niños que viven situaciones verdaderamente difíciles y cometen suicidio, lo hacen debido a que no pudieron comprender la circunstancia para resolverla. No obstante, debe entenderse que la falta de comprensión o entendimiento no obedece por el hecho de ser niños, como si esa condición biológica les impidiera comprender. Claro, los niños no comprenden muchas cosas, pero se debe por su historia interactiva 
tan "corta". De lo contrario, tendríamos que suponer que los adultos comprendemos todo lo que ocurre en el mundo gracias a nuestra "larga" historia.

Los suicidios infantiles, de adolescentes, de adultos y de la vejez pueden ser diferentes cualitativamente entre sí, pero esto no significa que obedezcan a distintos principios conductuales. No se justifica la creación de teorías particulares para cada etapa de la vida pues es una trampa del lenguaje en que caemos debido a la falta de claridad conceptual.

\section{Críticas en la aproximación del suicidio}

No está de más aclarar los cuestionamientos más comunes que se le hacen a los psicólogos u otros especialistas cuando se aproximan a los fenómenos de su objeto de estudio, en este caso al comportamiento suicida.

Una crítica común es aquella que tiene que ver con la supuesta inaccesibilidad a los estados y pensamientos de quien se suicida. La crítica concreta es la siguiente: si no somos nosotros la persona que desea suicidarse o nunca hemos estado en una situación similar, entonces estamos imposibilitados de entender aquello que siente y sufre la gente suicida. Esto significa que nunca podremos entender por completo lo que ellos viven "en carne propia", un proceso suicida. En el mejor de los casos, sólo podremos alcanzar un conocimiento parcial.

Esta falsa crítica está apoyada por la postura mentalista que confunde los eventos privados con los públicos. Pensemos en el típico caso machista donde una mujer es víctima de violencia en pareja. Su esposo la golpea constantemente por desobedecerlo y este, mientras la golpea, le dice "entiende, lo hago por tu bien". Conforme pasa el tiempo la dinámica es la misma o incluso se acentúa. Un día se le pregunta a la mujer por qué se deja golpear por ese barbaján, a lo que ella contesta "él es bueno conmigo, lo hace por mi bien". Cualquiera de nosotros que no formamos parte de esa situación o que nunca hemos vivido una relación de pareja de esa forma, podemos observar que la mujer ha aprendido a juzgar la situación con base en lo que se le ha dicho mediante a golpes. Sin embargo, el hecho de que nos encontremos "fuera" de dicha situación permite que nos demos cuenta de la dinámica que ejerce control sobre el comportamiento de la mujer. Con esto quiero mostrar que estamos en mejores condiciones para comprender las interacciones psicológicas, incluyendo aquellas que se relacionan con el comportamiento suicida.

El hecho de que nosotros no seamos la persona que tiene los deseos y pensamientos de suicidarse no significa que nos sea imposible comprender los motivos del suicidio. Por el contrario, como psicólogos estamos en condiciones de ayudarle al suicida, haciéndole explícitas las condiciones situacionales y de contacto funcional que se han construido históricamente y que conforman las interacciones psicológicas actuales. Justamente, ésta tendría que ser tarea del psicólogo clínico en un caso similar: hacer una reconstrucción de las relaciones interactivas previas del individuo y señalar las condiciones presentes que mantienen la dinámica de pareja actual.

No sobra decir que este argumento también aplica para otros tipos de interacciones psicológicas y no solamente para el estudio del comportamiento suicida. De lo contrario, en el sentido estricto nunca podríamos llegar a entender los comportamientos de los demás, seamos psicólogos o no. Por ejemplo, un oncólogo médico jamás estaría en condiciones de curar y atender el cáncer si no la padece. El consejero matrimonial no podría entender la vida y di- 
námica del matrimonio si nunca ha estado casado ${ }^{8}$. Todo aficionado y experto en el deporte se verían imposibilitados de comprender la presión que tiene un jugador de futbol en una final del mundial si nunca ha pateado siquiera un balón. Y así en cada ámbito.

Otra crítica muy común que se le hace al psicólogo y que está bastante relacionada con la anterior sostiene que las ideas suicidas son internas, por lo que no es posible observarlas directamente. Lo único que podemos hacer es detectar indirectamente aquello que algunos han mal llamado "señales silenciosas". La mayoría supone que existen diferentes actividades o comportamientos complejos que llevamos a cabo de forma encubierta u oculta como pensar o imaginar. Estas actividades cognitivas o mentales suponen ser cualitativamente distintas de aquellas que hacemos de forma observable para otros, como hablar, ver o comer.

Por ejemplo, imaginemos que un hombre enfrenta terribles problemas laborales y familiares que lo han llevado a una severa tristeza de lo que le espera en el futuro. Un día el hombre se encuentra acostado a obscuras en su habitación sin moverse. Simplemente se encuentra con la mirada fija hacia el techo. Después de algunas horas, se levanta, toma el teléfono y comenta a su mejor amigo que ha llegado a la conclusión de que el suicidio es lo mejor que puede hacer con su vida. Cualquiera pensaría que realizó diversas acciones u operaciones cognitivas complejas. En cambio, si la misma persona desde un inicio le hubiera hablado a su amigo y expresado sus pensamientos, supondríamos que hizo algo de menor complejidad que cuando estaba callado o, en todo caso, que su hablar es resultado de una acción previa no observable. Esto es simplemente falso o, mejor dicho, un malentendido.

Los pensamientos no son acciones visibles o no visibles, ya que estos no son cosas a modo de objetos. Cuando pensamos no estamos haciendo alguna actividad de forma oculta o no oculta. El carácter silente o no audible de nuestros pensamientos es lo que lo dota de misterioso y complejo a las "actividades mentales". ¿Entonces qué es lo que ocurre? Lo que sucede es que, por lo general, pensamos sin emitir sonidos o sin realizar actividad alguna, esto es, respuestas no aparentes. Simplemente, así lo hemos aprendido. Usted puede ver cómo los niños siempre que piensan lo hacen hablando, pero llega un momento en que logran pensar sin hablar porque se le ha enseñado a "guardar silencio".

En el caso del suicidio, las supuestas señales silenciosas no son respuestas encubiertas del comportamiento que ocurren en nuestros adentros, más bien son respuestas no aparentes. ¿Qué quiero decir con esto? Qué piensa cuando alguien piensa "me quiero suicidar", eso que pensó también lo podría decir en forma audible, sin que esto signifique que el primero sea el pensamiento mismo o una propiedad definitoria de algo más profundo?.

8 Los sacerdotes de la Iglesia católica tienen prohibido contraer matrimonio, y paradójicamente, proporcionan consejos para la vida marital.

$9 \quad$ Siguiendo el análisis argumentativo de Ryle (2002), cuando pensamos y hablamos no estamos haciendo dos cosas cualitativamente distintas. Hacemos sólo una: pensamos hablando. No pensamos en el vacío o sin uso de las palabras del lenguaje. La dicotomía es falsa. Incluso si se sostuviera esta dicotomía, el orden de las acciones sería al revés de como creemos, es decir, no pensamos y luego hablamos. Más bien, primero hablamos y en algún momento pensamos. Por ejemplo, supongamos que alguien nos propone un negocio y nos dice "No me digas ahorita tu decisión. Piénsalo y luego me dices". Por la forma de la expresión pareciera que el pensamiento es primero y el hablar o decir sería su consecuencia. Sin embargo, como ha señalado Vygotski (1988;1979), el lenguaje es la herramienta del pensamiento y nunca se da de manera previa e independiente del habla. 
Las señales suicidas no son expresiones que se "escapan" de aquello que esta encubierto. Simplemente, no hay señales silenciosas o no silenciosas.

Una vez descrita la propuesta interconductual y de realizar las aclaraciones pertinentes acerca de la lectura del suicidio desde esta perspectiva, es momento de pasar a los lineamientos para el estudio experimental básico de este comportamiento.

\section{Lineamientos básicos para el análisis experimental del comportamiento suicida}

Todo programa de investigación en psicología debe tener como prioridad la generación de conocimiento novedoso para la comunidad científica, posteriormente divulgarlo a profesionales y público en general y, finalmente, derivar tecnología de utilidad social. Esto es deseable que ocurra sin importar cuál sea el fenómeno psicológico que se pretenda estudiar.

¿Cuáles son los objetivos que deben cubrir las diferentes líneas de investigación en un programa de estudio del comportamiento suicida en psicología? Son varios los objetivos iniciales, no obstante, el principal de todos ellos debe estar encaminado a la identificación y determinación del efecto real de los factores participantes en esta forma de comportamiento. No todos los factores que creemos tienen un papel interviniente en el suicidio, ni tampoco tienen mayor relevancia unos de otros. Es por eso, que nos interesa aislar el efecto de uno de estos factores (análisis molecular) y su relevancia funcional en los episodios interactivos conductuales totales (análisis molar).

Algunos de los objetivos iniciales que propongo, con base en los postulados interconductuales y conforme la teoría de la conducta, para el desarrollo de líneas de investigación básica en el comportamiento suicida en psicología son los siguientes:

1. Analizar conceptual y teóricamente la definición de comportamiento suicida.

2. Determinar qué tipo de funciones psicológicas tiene lugar en el comportamiento suicida.

3. Analizar sistemáticamente la segmentación funcional del comportamiento suicida en función de los elementos propuestos en el modelo de campo interconductual.

4. Determinar la estructuración de regularidades conductuales de control de objetos estímulos y las transiciones funcionales de diferente complejidad a formas de comportamiento características del suicidio.

5. Elaboración y diseño de situaciones orientadas a la evaluación y desarrollo del comportamiento suicida.

6. Diseñar preparaciones experimentales para el control del comportamiento suicida.

El programa de investigación básica en comportamiento suicida debe de contemplar el análisis de los siguientes problemas: 1) el papel funcional del lenguaje como vehículo auspiciador de interacciones autorreferenciales que forman parte sustancial del comportamiento suicida, y 2) la transición de formas de interacciones selectoras y sustitutivas referenciales y no referenciales.

Si bien, el comportamiento suicida, como cualquier otro comportamiento, es un fenómeno conductual multifactorial, esto no significa que se necesita de la presencia de todos los factores reportados en la literatura para producirse. La investigación rigurosa determinará cuáles son los factores participantes y qué otros sólo potencialmente. 


\section{Elección del presuicida}

Es importante señalar algunas consideraciones acerca de la elección del individuo que denominaré como presuicida cuando se trate del control de esta forma de comportamiento. La elección del presuicida debe realizarse en función del objetivo de la investigación, es decir, de las variables que deseamos manipular como el sexo, preferencias o tendencia particulares, historia interactiva, etc. Es claro que hay que tomar en cuenta la facilidad, la economía y los costos generales para poder elegir a nuestro presuicida.

Pero, ¿qué personas y por qué deberían de ser nuestros presuicidas para una investigación de esta naturaleza con este propósito? En principio, propongo que sean todas aquellas personas que lo único que han hecho con sus acciones es perjudicar a otros. Me refiero específicamente a los secuestradores que se llevan a nuestros seres queridos, y en muchos casos no nos los regresan. A los violadores y feminicidas que abusan con la fuerza física para cometer actos sexuales en contra de la voluntad de los demás. A los asesinos que terminan con la vida de la gente como si se tratase de un objeto más en el mundo. A los pedófilos que lo único que hacen es dañar a los niños en su desarrollo psicológico y social. A los racistas que pretenden excluir a la gente con base en argumentos bastante pobres e injustificados. A la gente que maneja las diversas redes de esclavitud sexual y hacen negocios con la trata de personas. Podría seguir con una lista larga y específica, pero hasta aquí lo dejaré pues creo que el lector ya habrá comprendido cuál es el punto. Más adelante volveré a este aspecto de la selección del presuicida, pues su importancia no es menor.

Para finalizar este capítulo, debo reiterar que la investigación científica rigurosa, sistemática y coherente tendrá como consecuencia la derivación de tecnología aplicable y útil en distintos ámbitos. Por ello, es fundamental que como psicólogos entendamos que lo primordial de nuestra disciplina es hacer ciencia de calidad y excelencia. Como alguna vez indicó Karl Marx: "La ciencia no debe ser un placer egoísta [...] Los que tienen la suerte de poder dedicarse a las tareas científicas deben ser los primeros en poner sus conocimientos al servicio de la humanidad" (Lafargue, s.f., p. 4). Debemos trabajar en favor de la humanidad, incluso cuando en ocasiones se atente contra la propia humanidad. En este sentido, los psicólogos no somos de ninguna manera personas que permanecemos encerradas en laboratorios alejados de las problemáticas sociales, por el contario, somos científicos que siempre participamos en la vida pública y en la lucha contemporánea por el bien común. 


\section{CAPÍTUlo 5}

\section{Tecnología interconductual aplicada al comportamiento suicida}

Al intentar resolver los problemas que nos afectan en nuestro mundo actual, espontáneamente echamos mano de aquello que somos capaces de hacer mejor. Buscamos seguridad, y nuestra seguridad es la ciencia y la tecnología

B.F. Skinner

Es común encontrar en casi todas las civilizaciones de la antigüedad distintas atribuciones o características a dioses y divinidades de diferente jerarquía, por ejemplo, Zeus era el dios del trueno, Tláloc el dios de la lluvia, Odín el dios de la sabiduría, Alá es omnipotente y Dios es todo poderoso ${ }^{1}$. Estos dioses, fuerzas divinas o seres mitológicos, en ocasiones, eran bondadosos al dar lluvia para la nutrición de los cultivos en la tierra, proporcionar un clima favorable para la vida, ayudar a los mortales en sus problemáticas diarias a manera de "milagros", etc. En otras ocasiones, desataban su furia con terremotos, plagas, enfermedades y desgracias en general. Pero, más importante aún es que controlaban la vida de cada individuo mortal. A partir de las decisiones de los dioses, las vidas de los individuos eran de una forma u otra en particular. El destino de todos los seres humanos estaba en las manos de estos dioses y sus decisiones se veían reflejadas en la realidad.

Con la entrada del cristianismo en la Edad Media se establecería la idea de un Dios único que otorgaba libertad para elegir entre el bien y el mal. En caso de elegir el bien, el hombre tenía la oportunidad de entrar al reino de Dios, obedeciendo los mandamientos impuestos en los textos sagrados.

$1 \quad$ Los diferentes dioses de las religiones tienen un nombre propio que permite distinguirlos de otras divinidades. Sin embargo, el dios del cristianismo no tiene un nombre específico. Al respecto, el apologista cristiano romano Minucio Félix describió a Dios en el Octavius de la siguiente forma: "Y no busques una denominación para Dios; Dios no es un nombre. Hay necesidad de vocablos, cuando se ha de dirimir una multitud de denominaciones para sus propias características. Para Dios que es único, el término de Dios lo es todo; si le llamare padre, le consideraría terrenal; si se le llamara rey, le conjeturaría carnal; si le llamase señor, le supondría con seguridad mortal. Quita las denominaciones de los nombres y verás su fulgor." (Bodelón, 1994-1995, p. 56). 
Sin embargo, estas ideas de deidades que escriben el destino de todos nosotros o que permiten el ingreso de los mortales a otro mundo de naturaleza celestial, empezó a cambiar a partir del pensamiento racionalista de René Descartes. La duda cartesiana expresada en la máxima "Pienso, luego existo" trajo consigo la duda acerca de la existencia de Dios y la reafirmación del ser humano para así dar un giro al estilo "copernicano" y ser pieza fundamental para el pensamiento de la época del Renacimiento: Dios fue desplazado por el hombre y éste ocupó el centro de todo interés. Desde ese momento, el ser humano es responsable de sus actos y tiene en sus manos la forma de construir el mundo.

La tecnología, que se deriva del conocimiento científico, es un notable ejemplo de la construcción de este mundo hecho por el ser humano, a tal grado que ha transformado rápidamente el planeta, obligándonos a superar día con día lo realizado. Ya no hay dioses, sólo hay seres mortales que modifican su ambiente, incluyendo a ellos mismos, a través de sus creaciones tecnológicas haciendo imposible imaginar una vida sin ciencias aplicadas.

A continuación, explicaré en qué consiste la tecnología, cuáles son sus propósitos y cuál es su forma de proceder. Además, describiré y justificaré la propuesta de intervención tecnológica en el control del suicidio derivada de la psicología interconductual para la generación de nuevas interrogantes para la ciencia.

\section{¿Qué es la tecnología?}

El Diccionario de la Lengua Española dice que la tecnología es el "conjunto de teorías y de técnicas que permiten el aprovechamiento práctico del conocimiento científico" (RAE, 2017). Esta definición nos remite directamente a la distinción entre la ciencia y su aplicación social, es decir, la tecnología. Recordemos que tanto la ciencia como la tecnología persiguen diferentes propósitos. Por un lado, la ciencia se ocupa de la generación de conocimiento de los fenómenos de la naturaleza; por otro lado, la tecnología es definida como el conjunto de aplicaciones prácticas que se derivan de los conocimientos científicos para propósitos concretos en el contexto social, es decir, para modificar o transformar un evento particular de la realidad.

Sin embargo, a pesar de que la ciencia y la tecnología tienen distintos objetivos, éstas se encuentran relacionadas de tal manera que ambas se afectan recíprocamente. Por ejemplo, el interés de la ciencia química gira sobre la composición, estructura y propiedades de la materia, así como sus cambios. Si un químico desea investigar los cambios en la composición de dos sustancias al ser mezcladas a cierta temperatura, entonces aquellas observaciones y resultados van a nutrir el conocimiento en la química general. Ese conocimiento que se generó en el laboratorio en potencia puede derivar tecnología, como la elaboración de vacunas y medicamentos para quienes padecen enfermedades. Esto ocurre sin que necesariamente los químicos realicen experimentos con la pretensión de generar aplicaciones para ayudar a la humanidad.

En su contraparte, en el ámbito de la tecnología, un ingeniero en alimentos desarrolla y elabora alimentos para mejora nutricional con base en el conocimiento que producen los científicos en química y otras ciencias. El fin que persigue la tecnología es la transformación de la sociedad mediante sus aplicaciones.

Por ejemplo, los físicos tienen como propósito entender el comportamiento de la energía y su movimiento. Para lograrlo realizan diversos experimentos con la finalidad de formular leyes acerca de la naturaleza del universo. Sin embargo, la elaboración de fórmulas que explican el comportamiento de la energía ha hecho posible, de forma in- 
directa, la construcción de diversas armas bélicas como la bomba atómica que se arrojó en Japón durante los últimos años de la Segunda Guerra Mundial.

El desarrollo de la tecnología efectiva surge a partir de la derivación de conocimiento científico y de la transformación de las categorías de la ciencia básica, nunca mediante la extrapolación directa del conocimiento científico. En este sentido, para desarrollar tecnología psicológica interconductual es necesario cumplir al menos con dos condiciones necesarias (Ribes, 1982):

1. La existencia de un cuerpo científico producto de la investigación básica que permite la vinculación de una metodología aplicada sustentada en supuestos teóricos y filosóficos.

2. Un lenguaje especializado que permita que la aplicación tecnológica a situaciones concretas sea efectiva.

Incurriríamos en un grave error si intentásemos desarrollar tecnología desvinculada del conocimiento científico básico, pues caeríamos en el pragmatismo ecléctico absurdo que lamentablemente vemos diariamente en el "profesional" en psicología. Ejercer actividades profesionales al margen de la fundamentación teórica proveniente de la ciencia básica y de sus procedimientos empleados tiene como consecuencia inmediata la imposibilidad de desarrollar intervenciones con resultados efectivos consistentes.

En otras palabras, para generar tecnología con alcances efectivos es prerrequisito que exista un conjunto de conceptos teóricos y de operaciones vinculadas a la investigación básica, que permita la derivación de técnicas o procedimientos aplicados a la solución de problemas sociales, y así dar la transformación de eventos singulares y concretos (Ribes, 2009).

\section{Estado actual de la tecnología psicológica en el suicidio}

La tecnología psicológica que más se elaborada es aquella que se desarrolla en los siguientes tres ámbitos sociales:

- Educativo: la elaboración de programas de lecto-escritura y de estrategias en la enseñanza-aprendizaje son las derivaciones tecnológicas más significativas de la psicología en la educación. Además de la generación de material didáctico que surge de la evidencia empírica no se limita únicamente a la educación formal.

- Organizacional: en este ámbito destacan las pruebas psicométricas para selección y reclutamiento de personal en el área de recursos humanos. También sobresalen las estrategias para la mejora en el desempeño de puestos y la elaboración de perfiles con base en competencias laborales.

- Clínico: la tecnología psicológica en este ámbito consiste en el uso de diversos procedimientos terapéuticos, así como el desarrollo de técnicas conductuales. Por ejemplo, la desensibilización sistemática, modelamiento, administración de contingencias, economía de fichas, práctica reforzada, autocontrol, por mencionar algunas. Esta tecnología está encaminada a la solución de problemas interpersonales e intrapersonales de la vida cotidiana, tales como la violencia familiar, relación disfuncional en pareja, depresión, baja autoestima, etc.

En este último, el ámbito clínico, los casos de suicidios se atienen mediante la prevención y el tratamiento de aquellas personas con tendencias a cometer dicho acto. Se trabaja principalmente en la atención de quienes "sobrevivieron" al intentar cometer el acto, así como aquellas personas que fueron "víctimas" del suicidio de alguien cercano. 
Las universidades e institutos de la salud de todo el mundo han mostrado gran interés en estudiar el fenómeno del suicidio y en la elaboración de diferentes tecnologías para su aplicación en la sociedad. Muestra de ello son las múltiples y crecientes investigaciones de las ciencias sociales y de la salud, en especial el desarrollo de instrumentos para atenderlo como problema de salud pública. Antes de continuar debemos de preguntarnos cómo se ha estudiado el suicidio y qué nos dicen dichas investigaciones desde la psicología, pues en función de lo que se ha encontrado se derivan diferentes tecnologías con el propósito de incidir en el comportamiento suicida.

Los estudios del suicidio en psicología consisten, en su mayoría, en la elaboración de descripciones y correlaciones estadísticas de suicidios mediante el uso de diversos instrumentos como cuestionarios, pruebas psicométricas y los diagnósticos por medio de entrevistas en terapia y servicio psicológico general. El método por excelencia para obtener datos e información general del suicidio es por medio de encuestas, con pequeñas muestras representativas de una población (hogares, escuelas, empresas) y de estudios en la práctica clínica que son publicadas periódicamente. De esta forma, la psicología recurre a dicha información para aproximarse al fenómeno. Por ejemplo, el Instituto Nacional de Estadística y Geografía (INEGI) reúne información de intentos de suicidio y suicidios consumados. Obtiene todos estos datos a partir de los certificados de defunción por suicidio, número de suicidios por entidad federativa, lugar de residencia, edad, sexo, tipo de instrumentos empleados, religión, estado civil, escolaridad, entre muchos otros más (INEGI, 2017).

A partir de esta valiosa información, los psicólogos y especialistas de la salud comienzan a realizar investigaciones. Más adelante haré un señalamiento al uso excesivo de este tipo de investigación dentro de la psicología. Ahora bien, en lo que respecta a la psicometría en general se han desarrollado varias medidas e instrumentos de evaluación para el comportamiento suicida. Algunos de los más utilizados en el mundo por su rigurosa validez son los siguientes:

1. Inventario Multifásico de la Personalidad Minnesota (MMPI y MMPI-2)2.

2. Escala de Ideación Suicida de Beck.

3. Escala de Desesperanza de Beck.

4. Escala de Expectativas Sobre Vivir-Morir de Okasha.

5. Escala de Depresión del Centro de Estudio Epidemiológicos.

6. Cuestionario de Intento de Suicidio.

7. Escala de Letalidad.

8. Escala de Estimación de Riesgo Suicida.

9. Escala Tentativa Suicida.

Estas pruebas psicológicas, que son las principales de uso también en México, son derivaciones de los estudios bajo un marco teórico muy particular. Es por eso que menciono tres puntos importantes acerca de estas pruebas.

2 El MMPI no fue diseñado originalmente para el diagnóstico del suicidio. No obstante, es utilizado con frecuencia para identificar aquellos rasgos de personalidad que estén relacionados con posibles tendencias suicidas. En la actualidad las diferentes versiones posteriores a la prueba original, como el MMPI-2, han sido de gran ayuda de aplicación en los ámbitos clínicos, forense y laboral (Casullo, 1999). 
Primero, toda la información que se obtenga a través de éstas es considerada como indicador indirecto de las ideaciones suicidas, pues se parte del supuesto de que las ideas son lo esencial del suicidio, y por sus características no especiales éstas no pueden medirse y evaluarse de forma directa (Clemente y González, 1996; Mondragón, Borges y Gutiérrez, 2001; Rivera y Herrera, 2002). La cuantificación es crucial en las pruebas psicológicas objetivas, pues con ello se da confiabilidad y validez a la información que se obtiene a través de ellas. Segundo, estas pruebas se construyeron como escalas e inventarios a partir de variables sociodemográficas y clínicas que se reportan de las personas suicidas, no como pruebas ad hoc a cada persona que posee una historia psicológica particular.

Pero, ¿exactamente cómo están constituidas estas pruebas? Tomaré como ejemplo la prueba Suicide Intent Scale (SIS) por ser un modelo representativo. El SIS es una prueba que se ha utilizado bastante en los últimos años para predecir los intentos de suicidio. La prueba consiste en una entrevista de 15 reactivos que supuestamente cuantifican el comportamiento verbal y no verbal (Beck, Kovacs y Weissman, 1979; Ellis, 1986; 2008). Cada uno de los reactivos proporcionan "pistas" que pueden facilitar el descubrimiento de las tendencias suicidas.

Ahora bien, existen otro tipo de pruebas psicológicas denominadas proyectivas, tales como El Test de la Figura Humana (Portuondo, 2012) y la prueba HTP (Buck y Warren, 1995), que a pesar de ser tan populares son poco confiables sus resultados e interpretaciones. Incluso, algunas pruebas proyectivas que han sido utilizadas para evaluar el comportamiento suicida son simplemente absurdas, por ejemplo, el Test del Árbol y el Mandala que pretenden adentrarse a "la vida interior" de las personas (Eguiluz, 2010; Asch, 1980).

La información que se obtiene de las diferentes pruebas (objetivas y/o proyectivas), junto con los datos estadísticos e investigación del área, permiten la elaboración perfiles psicológicos de los suicidas. En la tabla 1 se mencionan algunas de las características y señales típicas de la persona suicida de acuerdo con investigaciones de los últimos años (Beck y Lester, 1973; Borges, Orozco, Benjet y Medina-Mora, 2010; Martín del Campo, González y Bustamante, 2013; Pérez, 2007).

Son muchos más los factores que se han documentado en la literatura especializada. Estos factores, ya sea como indicadores o causas ${ }^{3}$, del comportamiento suicida son frecuentemente enunciados en las investigaciones y suponen que con base en ellos es posible predecir el riesgo inmediato de que éste ocurra. De acuerdo con los expertos, todos estos factores son variables de altísimo potencial suicida, pero en ningún caso la existencia de una sola es suficiente para provocar el suicidio, por el contrario, varían en función de la edad, sexo e influencias sociales y culturales.

Pero, como el lector ya se habrá percatado, la lista es amplia y ambigua, lo cual no ayuda mucho. Por ejemplo, uno de los factores es la rebeldía. Pero ¿a qué tipo de rebeldía se refiere? ¿rebeldía como una reacción violenta, como una forma de protesta o cuál? ¿rebeldía a qué y con quién? Los expertos nunca aclaran lo que quieren decir con cada uno de estos factores potenciales del suicidio, así como la mayoría de las características que describen en los perfiles suicidas.

3 Es muy grave que en la propia literatura especializada se traten a los indicadores del suicidio como sinónimo de causas y características de las personas suicidas, pues es evidente que no son las mismas cosas. Si el lector investiga por su cuenta encontrará que no hay much claridad entre las categorías de diagnóstico, características etiológicas y descripciones sintomáticas. Sin embargo, es entendible que esto ocurra así, dada la situación actual de la disciplina, sobre todo por la falta de un lenguaje especializado en psicología. 
Tabla 1. Características típicas de las personas propensas al suicidio

\begin{tabular}{|c|c|c|c|}
\hline Tristeza & Disfunción familiar & Depresión & $\begin{array}{l}\text { Abuso de sustancias } \\
\text { (consumo de alcohol y drogas) }\end{array}$ \\
\hline Angustia & Trastorno de Personalidad & Separación marital & Factores climáticos y geográficos \\
\hline Ansiedad & Manifestación de ideas suicidas & Baja autoestima & Desempleo y reveses de fortuna \\
\hline Retraimiento & Abandono y soledad & Abuso paterno & $\begin{array}{l}\text { Padres distantes emocionalmente y mala } \\
\text { comunicación }\end{array}$ \\
\hline Ausentismo & Creencias religiosas & Notas suicidas & $\begin{array}{l}\text { Perfeccionismo hacia uno mismo y hacia } \\
\text { los demás }\end{array}$ \\
\hline Violencia & Problemas de personalidad & Desesperanza & Factores climáticos y geográficos \\
\hline Pobreza & Exclusión social & Marginalización & Ruptura de la relación erótica o amorosa \\
\hline Educación & Muerte de un ser querido & Fracaso escolar & Altos niveles de autocrítica \\
\hline Jubilación & Conflicto generacional & Celos y envidia & Familia con historial suicida \\
\hline Guerras & Disponibilidad de armas de fuego & Discriminación & Entrega de posesiones valiosas \\
\hline Rebeldía & Rigidez y constricción cognitiva & Deseos de morir & Aparición de alguna enfermedad física \\
\hline Internet & Falta de confianza en uno mismo & Pérdida del poder & $\begin{array}{l}\text { Disminución del rendimiento } \\
\text { (académico, laboral, sexual, etc.) }\end{array}$ \\
\hline Desinterés & Alejamiento de la familia & Sucesos estresantes & Preocupación por el tema de la muerte \\
\hline Agresividad & Pensamiento dicotómico & Amenazas suicidas & $\begin{array}{l}\text { Cambios en los hábitos de aseo, sueño y } \\
\text { alimentación }{ }^{*}\end{array}$ \\
\hline Bullying & Descomposición social & Migración & Incremento en la urbanización \\
\hline
\end{tabular}

Nota: Existen teorías de cómo la alimentación podría influir en el suicidio. Por ejemplo, diversas investigaciones han registrado que las poblaciones que se alimentan con preferencia o exclusivamente de cereales tienden a la agresividad y autoagresividad en comparación de la población que no tiene mucho consumo de cereal (Mawson y Jacobs, 1978).

Con este contexto, no es extraño que existan numerosos estudios absurdos y carentes de relevancia en lo que refiere al comportamiento suicida. Por ejemplo, se ha documentado que existe mayor propensión de quitarse la vida los días miércoles, en comparación con los demás días de la semana en personas mayores de edad en Estados Unidos (Kposowa y D’Auria, 2010). Esta investigación, así como muchas de este tipo, no es más que la correlación estadística de variables sin importancia, es decir, podríamos realizar un estudio que relacione el tipo de vestimenta con el día de la semana en que se comente suicidio y encontrar "regularidades" que "expliquen" el suicidio. O podríamos estudiar la relación que hay entre la altura de las personas respecto a la modalidad del suicidio. Podríamos hacer toda clase de relaciones sin sentido. Simplemente, son datos inútiles que lo único que hacen es desvirtuar las investigaciones y desviarnos de las preguntas realmente importantes. 
Con tantos factores se puede pensar que "todo" y "nada" puede provocar el suicidio. Visto así, parece ser que la combinación de los factores que dan como resultado el suicidio es una suerte de la lotería. Esto genera más misterio e incertidumbre al respecto.

Por otro lado, los perfiles psicológicos parecen no ayudar demasiado, por el contrario, pueden llegar a ser contradictorios entre las características que señalan y confundir más aun todo. Por ejemplo, algunos especialistas reportan que las personas ateas tienen mayor probabilidad de cometer suicidio, pero también las personas religiosas fanáticas tienden a suicidarse mayoritariamente. Con semejantes contradicciones y variada combinación de múltiples factores desencadenantes del suicidio no es sorprendente que hasta ahora no se haya podido prevenir con éxito dicho comportamiento en la gran mayoría de los casos.

A propósito de la prevención, también es común encontrar en la literatura especializada afirmaciones de que ningún acto de suicidio es repentino ni ocurre como un comportamiento impulsivo, por el contrario, siempre hay una planeación previa de alguien quien elabora la posibilidad de llevar a cabo el acto. De esta afirmación, surge la posibilidad de prevenir o evitar los suicidios en aquellas personas que son más propensas a llevarlo a cabo.

Sin embargo, se puede observar que en la vida cotidiana no siempre ocurre así, por el contrario, los suicidios se mantienen constantes pese a cualquier programa de prevención que considere todos los factores mencionados en la tabla 1 y otros más. Alguien podría argumentar que es obvio que estos factores tienen diferentes niveles de afectación en función de cada individuo, pues cada uno de nosotros posee una historia muy particular. Bueno, si esto es correcto, entonces no tiene sentido alguno elaborar perfiles generales de personas con tendencias suicidas, pues se está admitiendo que lo psicológico se construye de forma individual y no de manera uniforme respecto a otros.

Pero no todo se reduce a pruebas psicológicas y estadísticas poblacionales. Uno de los principales métodos de diagnóstico frecuentemente utilizado para estudiar el suicidio es el análisis de cartas póstumas, mejor conocidas como notas suicidas. Se analizan estos vestigios, si los llega a haber, con el fin de determinar las características emocionales, cognoscitivas, actitudinales, motivacionales, pensamientos, deseos y sentimientos del suicida vinculados al momento en que llevan a cabo su muerte. Estas expresiones finales pueden elaborarse por escrito, como las cartas o notas, e incluso en otras modalidades como pinturas, dibujos y videos (Águila, 2011; Chávez, Macías y Luna, 2001).

¿Cómo nos ayudan estos vestigios a entender el comportamiento suicida? Muchos colegas consideran a los vestigios como productos simbólicos que guardan la clave para entender este tipo de comportamiento. El análisis de los vestigios, absurdamente llamado "autopsia psicológica del suicidio", consiste en la exploración de las propiedades lingüísticas de aquello que se elaboró, a modo de mensaje o información, con la finalidad de obtener respuestas o conclusiones de por qué alguien llevó a cabo el suicidio. Esto quiere decir que la tarea principal consiste en identificar a quién se dirigen las cartas, su contenido y, de ser posible, encontrar las razones concretas por las que se suicidó una persona (Rodríguez, 2001).

Ahora bien, pareciera que cuando realizamos estas "autopsias" tenemos un acceso privilegiado a la mente del suicida. Es como si nos metiéramos en los pensamientos del suicida revelados en forma gráfica. Pero, no debe pensarse esto en forma literal, pues en realidad se tratan de interacciones que forman parte de un segmento particular en el continuo conductual del suicida. Dado que es demasiado importante este tipo de vestigio, es prioridad entender el sentido funcional de las palabras orales o escritas cuando se hace referencia a los aspectos psicológicos, aun cuando el 
propio suicida se haya expresado de otra forma. Lo que estoy sugiriendo es que haya una "traducción" del lenguaje coloquial al lenguaje técnico de la psicología para su análisis científico. A continuación, se mencionan algunos ejemplos de narrativas escritas por los suicidas y su posible interpretación funcional con el fin de mostrar la lectura psicológica que debe realizarse:

- Me odio a mí mismo. (Conducta sustitutiva autorreferencial en el subcaso de mediación de referente con propiedades del propio referidor).

- Estaría mejor muerto que con este sufrimiento. (Conducta sustitutiva mediando interacciones suplementarias ante un estímulo aversivo).

- No puedo seguir deprimido, tengo que terminar con este dolor que tengo en el alma. (Hace referencia a una "larga” historia interactiva como conducta sustitutiva mediando interacciones suplementarias en las que forma parte diferentes eventos de estímulo aversivos).

- Creo que el suicidio es la única opción que tengo. (La persona refiere a una interacción como contingencia cerrada, es decir, en donde únicamente hay una forma de respuesta funcional para satisfacer un criterio de logro. Carece de competencias para comportarse de manera efectiva y variada).

- Mi familia sería más feliz sin mí porque mi muerte tiene más valor para ellos que mi propia vida. (Se trata de interacción sustitutivas en las que hay una falta de correspondencia entre las prácticas conductuales familiares y las creencias de quien refiere la situación).

- A nadie le va a importar si me muero. No valgo nada ni merezco vivir. He perdido todo lo que me importaba. (Comportamiento en un nivel sustitutivo no referencial en un subcaso de mediación referencial de respuestas referenciales y no referenciales).

- No tengo futuro. Nada va a cambiar. No tengo ninguna esperanza. (Comportamiento en un nivel sustitutivo no referencial en un subcaso de mediación no referencial de respuestas no referenciales).

- Soy un inútil y no me quieren. (Conductas inefectivas ante diferentes criterios de logro valoradas. Dichas conductas han sido castigadas frecuentemente).

Debe quedar claro que la teoría de la conducta no es un modelo para hacer interpretaciones de los vestigios. Sería muy irresponsable y una incomprensión total de nuestra parte como psicólogos dar conclusiones profesionales a partir de unas cuantas frases y tomarlas de forma literal únicamente por el hecho de que quien las escribió fue el suicida. Debe entenderse que llamamos a este tipo de notas o cartas como vestigios, porque coloquialmente solemos pensar que son resultado directo de un comportamiento previo. Sin embargo, que una persona con tendencias suicidas "objetivase" sus pensamientos y sentimientos mediante la escritura no significa que sea resultado de algo previo, como si fuera un simple vaciado gráfico de algo más profundo en nuestra cabeza. Las notas suicidas son parte de interacciones psicológicas y no algo adicional o extensivo.

Ahora bien, las cartas póstumas son valiosas para el análisis del suicidio, pero presentan dos grandes problemas. Uno de ellos es la dificultad de estandarizar las interpretaciones, pues adolecen de la misma limitación que las pruebas proyectivas: cada psicólogo tiene un "estilo" diferente y particular de interpretar los escritos. 
Es claro que esto va más allá de los años de experiencia particular del psicólogo en el área o de algún manual interpretativo. Esto obviamente hace perder validez al instrumento empleado.

Nuestra labor parece ser un tipo de "arqueología psicológica" en la que intentamos reconstruir los verdaderos pensamientos detrás de tales escritos. La lógica que apoya este tipo de análisis deriva del supuesto dualista que supone que los pensamientos son internos y develados en forma de reportes verbales.

Existe otro problema en el análisis de las notas suicidas y tiene que ver con la adecuada forma de expresión del lenguaje escrito, es decir, la claridad de las ideas que se desea transmitir. ¿Cómo sabemos que el suicida se expresó correctamente? Supongamos que encontramos una nota de un adolescente que dice lo siguiente: "lo siento no puede soportarlo estoy muerto por dentro gracias a mi familia". A partir de esta nota, alguien podría pensar que el adolescente culpabiliza a su familia. Pero es posible que este adolescente no haya aplicado de forma correcta los puntos y comas, igual que muchos otros de su edad. Puede que el lector considere esto como una trivialidad, pero no lo es, pues si agregamos una coma o un punto entre las palabras "gracias" y "familia" el sentido cambia. Claro, su historia psicológica, biológica y social previa al acto suicida nos confirmaría varias cosas a las que hace referencia su escrito, pero aun así tendríamos que inferir muchas otras cosas.

Supongamos, contrariamente, que el suicida es capaz de expresarse a la perfección. ¿Habría que creerle a cada una de sus palabras? No estoy insinuando que una persona en una situación como esa nos mienta (aunque pudiera hacerlo), pero ¿cómo podríamos determinar con exactitud la intencionalidad de mensaje? ¿el suicida habrá explicitado las causas o nada más lo que quiere que creamos que fueron las causas que lo orillaron a terminar con su vida?

Con todo lo anterior, no quiero decir que los análisis de los vestigios sean inútiles. Por el contrario, son importantísimos y proporcionan bastante información de las posibles interacciones psicológicas previas que formaron la última conducta del suicida. Pero, es obvio que debemos tener en cuenta las limitantes de este tipo de análisis y especificar el contexto en el que se realiza tal producto.

\section{¿Qué sabemos del comportamiento suicida?}

El suicidio figura entre las principales causas de muerte a nivel internacional. Es la segunda causa de muerte en la población mundial entre 10 y 24 años y la tercera de los 15 a los 44 años, además se ha convertido en la tercera causa de muerte entre los adolescentes mexicanos, sólo superado por los accidentes automovilísticos y el cáncer (Borges, Orozco, Benjet y Medina-Mora, 2010; Higareda y Hernández, 2017; Jiménez y González, 2003).

En México, durante el año 1990, se registraron de forma oficial aproximadamente 2 mil 500 suicidios, por cada nueve varones suicidas había dos mujeres. Y, de acuerdo con el Instituto Nacional de Psiquiatría "Ramón de la Fuente Muñiz", se incrementó el número de suicidios entre los años 1990 y 2000, es decir, un aumento del 150 por ciento.

Ya en el año 2010, una década después, se había duplicado con poco más de 5 mil suicidios, de los cuales el 30 por ciento fueron cometidos por personas desempleadas. En el año 2011, de acuerdo con datos del INEGI, se registraron 5 mil 718 suicidios, mientras que en el 2012 fueron 5 mil 549 en el país (Maya, 2014). En el 2012, la tasa de suicidios a nivel mundial era de 11.4 por cada 100 mil habitantes (AFP, 2014). En resumidas cuentas, entre los años 1990 y 2012 se incrementó la tasa de suicidios en un 114 por ciento (Maya, 2014). 
En correspondencia con lo anterior, Margaret Chan, exdirectora general de la OMS, sostuvo que cerca de un millón de personas se quitan la vida al año, es decir, casi tres mil personas se suicidan al día. En los últimos años el sector más vulnerable es el de jóvenes de entre 15 y 24 años (Gómez, 2014; Méndez, 2014; Olivares, 2013). Esto significa que el suicidio afecta cada año a 800 mil personas en todo el mundo. Son más muertes que en guerra o catástrofes naturales.

De acuerdo con López (1998) las causas de los incrementos desde inicio de los 90 en nuestro país se deben, supuestamente, a graves problemas mentales en donde más del 85\% de los casos se tratan de algún tipo de depresión, demencia o esquizofrenia.

Por otro lado, diferentes reportes han documentado los métodos, lugares y los objetos que con más frecuencia utilizan las personas suicidas. Al parecer, cada persona lo hace con un "sello" particular, es decir, que no son seleccionadas de manera fortuita. Siempre hay razones particulares para que alguien prefiera morir de una forma y no de otra. De acuerdo con Marchiori (2000) existe una fuerte preferencia por las armas de fuego entre el sexo masculino para suicidarse, mientras que las mujeres utilizan métodos que no impliquen demasiada violencia. El método más utilizado por las personas para terminar con su vida es el ahorcamiento con el uso de una soga o cinturón. De hecho, el estrangulamiento y sofocación está por encima de los disparos con arma de fuego. Otros de los métodos más usuales, son las armas blancas, instrumentos cortantes, fármacos (drogas y alcohol), arrojarse de alturas (puentes y edificios), arrojarse a vías del tren o automóviles y consumo de venenos.

Respecto al lugar en donde llevan a cabo los suicidios, estos son variados. En México, de acuerdo a datos de INEGI, las personas eligen con mayor preferencia su vivienda para quitarse la vida. "Las mujeres ocupan el primer puesto de quienes mueren en su hogar (79.9\%), seguidas de los hombres (72.6\%)" (Téllez, 2014). Sin embargo, los hombres siguen siendo quienes comenten más suicidios año con año en comparación con las mujeres (AFP, 2014). Otros lugares recurrentes por los suicidas son los espacios públicos, religiosos, zonas turísticas y de transportes.

En resumen, sabemos que hay un aumento en el índice de suicido conforme pasan los años, especialmente un incremento en la población joven. Ante tal panorama, los especialistas de la salud han encargado de elaborar diversos programas de prevención del suicidio en función de las características particulares de cada población.

\section{Prevención del suicidio}

Una de las metas más ambiciosas de los profesionales de la salud se relaciona con la prevención del suicidio. De hecho, el día 23 de septiembre de 2003 se hizo oficial el Día Mundial de la Prevención del Suicidio con el objetivo de generar conciencia al respecto. Algunos países han realizado grandes esfuerzos por prevenir el suicidio, como Finlandia quien fue el primero en efectuar de forma completa una estrategia nacional para prevenir el suicidio. Con base en las recomendaciones de las Naciones Unidas, este programa preventivo ha sido el ejemplo a seguir para el resto del mundo, pues sus estrategias están basadas en la información proveniente de las investigaciones y las recomendaciones de diversos expertos de la salud y ciencias sociales (Bobes, Sáiz, García-Portilla, Bascarán y Bousoño, 2004).

Las acciones preventivas se dirigen de forma concreta a tres puntos: 1) intervención familiar, 2) intervención en la educación, y 3 ) intervención a personas que rodean a quien intenta el suicidio. Resulta obvio que la intervención más importante esté orientada a la familia y la educación, pues son las instituciones sociales por excelencia. 
Por un lado, la familia es el núcleo principal para el desarrollo biológico, psicológico y social de los individuos. Por otro lado, la escuela es el lugar propicio para inculcar los valores que se requieren en una determinada sociedad, especialmente los niños, y estos estén en posibilidad de apropiarse de las diferentes normas morales y éticas.

A pesar de ser muy completo este programa de prevención, tiene muy poco apoyo para la aplicación de experimentos. Esto obedece a las dificultades metodológicas y éticas a las que se enfrentan los científicos para experimentar con el suicidio. Es precisamente en este punto que considero que la experimentación se vuelve crucial y fundamental si se desea prevenir el suicido de forma efectiva mediante la elaboración de programas o estrategias. ¿Por qué? La experimentación es una parte importante para sustentar los hechos con datos válidos y resultados confiables.

Claro, la investigación realizada hasta el día de hoy es valiosa y ha servido de base para la elaboración de estrategias de prevención del suicidio. Sin embargo, no se ha podido, ya no digamos disminuir el número de suicidios en nuestro país y el resto del mundo, se ha vuelto una tarea imposible mantener el mismo número casos de suicidios. Contrario a lo que se pueda pensar, año tras año aumenta el número de intentos de suicidio y actos consumados. Los especialistas en su labor de investigación añaden cada vez más factores que suponen potencian la conducta suicida a tal grado que se vuelve casi imposible determinar con exactitud los verdaderos factores que influyen en el origen y desarrollo de este comportamiento.

Esto último, ha traído como consecuencia que los actuales patrones de la conducta suicida se desmoronen. Es decir, es tanta la información que se contradice y son numerosos los factores potenciales que lo promueve que es poca la certeza que se tiene respecto a la naturaleza del fenómeno. No es ninguna sorpresa entonces entender por qué falla la difícil tarea de la prevención del suicidio.

Debo mencionar que el método más recurrente para la prevención del suicidio, por ser el único que ha demostrado tener buenos resultados a corto y largo plazo, es el diagnóstico y tratamiento psicológico temprano. Fuera de eso, no se ha progresado mucho en términos de efectividad en la prevención, por el contrario, se ha incrementado su incidencia.

Entonces ¿qué es lo que pasa?, ¿acaso no es suficiente la investigación que existe al respecto?, ¿la investigación realizada es errónea? En realidad, no es suficiente la investigación actual en un sentido muy importante y que detiene el progreso para su conocimiento: no se han explotado todos los métodos de investigación para comprender el comportamiento suicida.

La mayoría de la investigación realizada en el siglo pasado y la que se continúa haciendo actualmente, está basada en teorías mentalistas que adolecen de errores conceptuales, y en las estadísticas poblacionales, que ya no nos dice nada más acerca de lo que ya sabemos.

Con este panorama, ¿qué es lo que debemos hacer? Lo primero es que reconozcamos los psicólogos las limitaciones teóricas y metodológicas del estudio del comportamiento suicida de las teorías actuales que se enfocan exclusivamente al análisis de esta conducta.

El segundo paso es reformular nuestros planteamientos y categorías de análisis que permitan el diseño de procedimientos originales para su estudio y aplicación tecnológica. Respecto a este último es necesario tomar en cuenta varios aspectos que a continuación mencionaré. 


\section{Consideraciones de la tecnología psicológica en el suicidio}

Todas las tecnologías psicológicas del suicidio están encaminadas a la prevención y tratamiento. Pero, ¿por qué desarrollar tecnología psicológica que tenga el propósito de controlar el suicidio en los individuos?, o sea, ¿qué acaso no se supone que la aplicación de la tecnología a la vida cotidiana se realiza con el objetivo de atender los problemas más apremiantes de nuestra sociedad? Sí, es cierto. Pero, también es cierto que la tecnología puede ser útil para plantear interrogantes para la ciencia aun cuando sea ha sido utilizada para desastres humanos.

A lo largo de la historia hemos visto que los avances científicos se han aplicado para la mejora de condiciones de la vida de los individuos y las sociedades. Pero, también es un hecho que el desarrollo de la tecnología ha tenido lugar en situaciones con propósitos bélicos, por ejemplo, las armas de guerra que van desde las catapultas utilizadas en la antigüedad hasta la creación de dispositivos explosivos como las bombas de destrucción masiva. En la Primera y Segunda Guerra Mundial podemos encontrar varios ejemplos en los que se requirió de cierta tecnología para la producción de armas precisas, potentes y letales, así como el desarrollo de venenos que se pudieran expandir entre la población. También se desarrollaron instrumentos como el radar y medios de comunicación que tenían como objetivo acabar con aviones y navíos enemigos. En el área de la psicología, se elaboraron de forma masiva diversas pruebas psicométricas para la selección adecuada de individuos para diferentes puestos militares, así como evaluaciones para la población en general por secuelas de la guerra. De hecho, en casi todas las guerras, los ganadores triunfan en gran medida por su tecnología desarrollada. Todo eso es tecnología. Desde las vacunas que acaban con las enfermedades hasta las armas para matar, nos guste o no. Claro, la cuestión ética respecto a la orientación de la tecnología es debatible. Con esto, no quiero decir que estoy a favor de este tipo de desarrollo tecnológico bélico que el único fin que tiene es torturar y matar a gente inocente.

Sin embargo, debemos entender que la dirección u orientación de la tecnología a una situación concreta obedece a intereses particulares y/o colectivos. Por ejemplo, si un empresario desea comenzar un negocio y requiere de una máquina que le permita producir su novedoso producto, entonces son los ingenieros mecatrónicos quienes se encarguen de diseñar y elaborar una máquina a partir del conocimiento científico disponible. $\mathrm{O}$ cuando un médico necesita de una vacuna para atender una determinada enfermedad en una población específica, la cual será solamente para el beneficio de aquellos que la usen, por ejemplo, los casos de los enfermos de ébola y los infectados por el zika. En los ejemplos anteriores, y en todas las situaciones de la vida cotidiana, la tecnología es siempre orientada con el propósito de transformar la realidad con interés y de utilidad para unos, inútiles para otros.

La pertinencia y legitimidad de todo desarrollo tecnológico depende en gran parte de los propósitos o fines que se pretendan alcanzar, además de las personas involucradas, ya sea como usuarios de dicha tecnología o como víctimas. En el caso de la tecnología como control del suicidio que aquí propongo tiene como objetivo manipular los diferentes factores que componen el campo psicológico para promover el comportamiento suicida y comprenderlo con fines científicos. Esto es algo que no se han planteado con otras alternativas metodológicas y otras tantas nunca lograrán hacerlo dadas sus limitaciones teóricas y conceptuales.

La tecnología no se trata solamente de aplicar el conocimiento científico a situaciones concretas de la vida cotidiana para cambiarla. Si bien, es cierto que gran parte de la tecnología se realiza a partir de la derivación y transformación de las categorías propias de la ciencia, también es cierto que el avance tecnológico puede (y de hecho lo 
hace) plantear problemas para la ciencia. Esto quiere decir que se puede dar el caso inverso donde la tecnología genere interrogantes para la ciencia ${ }^{4}$.

El desarrollo y uso de la tecnología que me interesa aquí es aquella que tiene el único fin de generar planteamientos novedosos a la psicología respecto al comportamiento suicida. No es de mi interés personal, al menos en este texto, el desarrollo de tecnología para la prevención del suicidio.

Paradójicamente, a pesar de la gran cantidad de literatura especializada en el tema y las numerosas investigaciones que describen y especifican las condiciones necesarias para su ocurrencia, resulta imposible predecir con exactitud cuándo alguien está a punto de cometer suicidio. De hecho, son pocos los estudios controlados que han demostrado tener efectividad para reducir el número de suicidios. La mayor parte de lo reportado en México, hasta ahora, nos dice que el suicidio se ha estudiado con una visión básicamente clínica y demográfica con pocas propuestas efectivas (sino es que nulas en la mayoría de las ocasiones) a nivel social e interdisciplinario.

La principal actividad de los psicólogos de los últimos años, en este tema, ha sido la identificación, recolección, comparación y relación entre los determinantes del suicidio para transformarlos en estadísticas poblacionales o en perfiles con características de los individuos suicidas. Le hemos dado el carácter de científico a todo este tipo de trabajo, pero sin cambiar nada que afecte propiamente al comportamiento suicida. No hemos logrado desarrollar distintas alternativas metodológicas efectivas para su prevención y atenderlo en la mayoría de la población ${ }^{5}$. Las estadísticas que ofrece INEGI claramente tienen utilidad para las transdisciplinas e interdisciplinas, pero esto no es una herramienta metodológica propia de la psicología ${ }^{6}$.

$4 \quad$ Véase dos casos clásicos de cómo la tecnología puede llegar a plantear interrogantes para la ciencia. El primer caso proviene de la ciencia física con el astrónomo matemático Galileo Galilei y la construcción de su primer telescopio. A pesar de que existían en ese tiempo las leyes de la óptica de Kepler, era imposible derivar tecnología con base en sus matemáticas (o por lo menos no se desarrolló alguno de esta manera). Por el contrario, con base en el ensayo y error, Galileo logró construir su telescopio y generar preguntas científicas a partir de sus observaciones de los astros. El segundo caso proviene de la biología con la construcción de los primeros microscopios y el descubrimiento de la célula y de bacterias no conocidas. El desarrollo de la teoría celular no hubiera sido posible sin la observación a partir de un instrumento tecnológico como el microscopio.

$5 \quad$ No hay que olvidar que la efectividad de toda estrategia de prevención del suicidio llevada a la práctica depende no solamente de los avances teóricos y metodológicos de la ciencia. Por un lado, se necesita de las políticas gubernamentales de salud para proporcionar cobertura a las demandas generadas por la presencia del suicidio. Dicho sea de paso, debo decir que en México aún carecemos de tales políticas de salud.

Por otro lado, la mayoría de los proyectos de investigación sobre la prevención del suicidio que se han realizado desde las universidades en nuestro país han quedado en eso: en simples y llanos proyectos. No se han transformado en programas de intervención social pues no existe una política académica de investigación dirigida a incidir y modificar este rubro en la sociedad.

6 Es obvio que la estadística y los métodos cuantitativos no constituyen en y por sí mismos la metodología propia de la disciplina psicológica. Por el contrario, la aplicación estadística, en cualquier tipo y nivel que sea esta, es pertinente y tiene sentido únicamente cuando se justifica con base en las preguntas de investigación que se plantean. Lo ideal es que la psicología desarrolle sus propias métricas y representación de datos para el estudio de sus fenómenos (Acuña, 2010; Pacheco y Carpio 2011). 
Además, hay que agregar que lo anterior no arroja grandes respuestas desde un punto de vista psicológico por el simple hecho de que no son evaluaciones elaboradas con base en categorías psicológicas. A pesar de las conveniencias de las múltiples tipificaciones y clasificaciones de suicidios que permiten organizar este fenómeno para nuestra compresión, para la psicología no es tan útil como parece en principio. Es más útil como herramienta para los sociólogos. Considero que la diversidad de los actos suicidas es muy amplia como para elaborar una tipificación precisa, pues cada suicidio es singular, irrepetible y distinto. Una tipificación de las formas que puede describir el comportamiento suicida tiene su utilidad, pero es limitada. Al menos en el área clínica se vuelve relativa su utilidad cuando se trata de prevenir el suicido.

¿Entonces qué hay que hacer? Propongo lo siguiente. En primer lugar, dado que el suicidio se concreta siempre como colección de actos individuales, aun aquellos casos de suicidio colectivo como ocurre en algunas sectas religiosas, lo más congruente es realizar un análisis intrasujeto, es decir, que cada persona actúa como control o referencia de su propio comportamiento. Con un análisis así, se estaría haciendo pertinentemente el análisis del desarrollo psicológico de la persona, pues cada suicidio es único e irrepetible. No debemos tomar como medida a otras personas que han construido diferentes relaciones interactivas psicológicas a lo largo de sus vidas. En todo caso, debemos considerar sólo aquellas conductas que funcionalmente comparten la misma estructura contingencial.

Por lo tanto, habría que considerar con cierta mesura, e incluso con desconfianza, todos aquellos estudios que muestran correlaciones y todo tipo de pruebas estadísticas que nos obligan a elegir entre hipótesis con los distintos factores. Dichas estadísticas se conforman en función de la norma poblacional, asumiendo que el impacto en todos los individuos es igual en la singularidad de cada uno. Hay que entender que lo que reportan las estadísticas son correlaciones y no descripciones de las causas del suicidio. Todos aquellos datos estadísticos que los psicólogos defienden como una explicación del suicidio siempre lo he interpretado como una forma elegante de decir que no saben nada acerca de aquello que pretenden explicar.

En segundo lugar, no hemos explotado todos los métodos para el estudio del suicidio, por ejemplo, el control de dicha conducta. Control no como prevención, sino como la manipulación y promoción de los factores para la réplica de este comportamiento suicida. Controlar este fenómeno conductual es un recurso metodológico que permitirá obtener una mayor compresión de esta conducta en su dimensión psicológica. Y si se desea, posteriormente, prevenir los suicidios con base en la comprensión obtenida. A continuación, desarrollo este punto del control en el suicidio.

\section{Análisis Contingencial: tecnología psicológica para el control del suicidio}

El Análisis Contingencial (AC) es un sistema tecnológico derivado de la lógica del modelo de campo interconductual y está dirigido al campo aplicado. El AC tiene por objetivo el cambio del comportamiento individual en la resolución de problemas. Este sistema interviene en los problemas que las personas describen en su vida cotidiana, por tanto, se trata siempre de una serie de eventos singulares y concretos. La eficacia del sistema en la modificación de las interacciones psicológicas valoradas como problemáticas está ampliamente documentada (Rodríguez, 1998; Rodríguez; 2010; Rodríguez y Landa, 1993; Rodríguez, Ángeles y Coello, 2003, Ribes, Díaz-González, Rodríguez y Landa, 1986; Rodríguez, Díaz-González y Anaya, 1999; Rodríguez, 2002). 
Ahora bien, la propuesta de intervención para el control del suicidio tiene como base principal este sistema tecnológico. Dado que el análisis y modificación del comportamiento suicida no es distinto en su naturaleza de otros tipos de comportamiento psicológico, la intervención para su control no es necesariamente diferente a lo que generalmente se atiende en el ámbito clínico. Sin embargo, para el control del suicidio los propósitos son distintos a los que comúnmente se observan en el ámbito clínico que tiene por objetivo la resolución de problemas a través del cambio del comportamiento individual. Nuestro propósito principal es manipular deliberadamente diferentes contingencias situacionales de un individuo, con el fin de controlar (promover) el comportamiento suicida, a fin de comprobar cuáles y cómo se relacionan las diferentes variables entre sí.

Para esto, es necesario que generemos y propiciemos la falta de correspondencias intrapersonales e interpersonales establecidas por un presuicida. Dicho coloquialmente, se pretende crear problemas individuales para que se cometa suicidio. El análisis contingencial aplicado al comportamiento suicida se compone de las siguientes dimensiones:

- Sistema Microcontingencial del presuicida

- Sistema Macrocontingencial del presuicida

- Génesis de las interacciones presuicidas

- Análisis de control contingencial presuicida

\section{Sistema Microcontingencial del presuicida}

Este primer sistema de análisis hace alusión a la red de relaciones que establece una persona en el campo de contingencias. Su objetivo principal consiste en la identificación de relaciones microcontingenciales problemáticas y no problemáticas. Los elementos fundamentales que componen las relaciones microcontingenciales del presuicida son: morfologías de la conducta, situaciones, persona y efectos. Enseguida se describen cada uno de los elementos.

\section{Morfología}

Se refiere a todas aquellas acciones que hace el presuicida, así como lo que hacen las personas con las que se relaciona, es decir, las formas concretas de comportamiento. Las acciones pueden ser tales como hablar, llorar, leer, escribir, disparar, cortar, aventarse, etc. En el caso de los presuicidas, las morfologías de interés son aquellas valoradas como problemáticas de las interacciones psicológicas, por ejemplo, mutilación del cuerpo, ingerir sustancias nocivas en exceso, etc. También son relevantes las morfologías no problemáticas que permiten el buen establecimiento de interacciones. De esta forma será posible identificar cuáles interacciones son necesarias promover y cuáles eliminar.

Las morfologías de respuestas de los presuicidas han servido de indicadores para que algunos psicólogos las interpreten como señales claras en la detección temprana de este comportamiento. Sin embargo, únicamente las identificamos y le damos relevancia con base en las situaciones en que ocurren estas interacciones.

\section{Situaciones}

Toda relación psicológica ocurre en una situación particular y en función de las características fisicoquímicas, biológicas y/o sociales presentes se puede favorecer, facilitar, entorpecer, impedir o hacer más o menos probable una forma de interacción. Algunas de las más comunes son: 
- Circunstancia social. Se trata la delimitación social en las que ocurren las interacciones, por ejemplo, las relaciones familiares, de amistad, de noviazgo, situaciones de trabajo, aprendizaje en la escuela, negocios, etc.

- Lugar (es). Hacen referencia al ambiente físico en que se está interactuando, como la universidad, una casa, un parque, un centro comercial, entre muchos otros. Los lugares pueden tener una función disposicional, esto quiere decir que probabilicen en mayor o menor medida determinadas relaciones psicológicas. Por ejemplo, un estadio de futbol pude favorecer a que los individuos expresen insultos verbales de forma más intensa y frecuente que en una iglesia.

- Objetos o acontecimientos físicos. Estos también pueden tener una función disposicional. Los objetos refieren a todas aquellas cosas que modulan nuestro comportamiento, como cuando alguien pasa enfrente de una iglesia puede que se persigne y se comporte de forma más seria. Por acontecimientos físicos se entiende aquellos eventos como los accidentes automovilísticos, inundaciones, huracanes, etc. Por ejemplo, si alguien experimenta algún tipo de desastre, como los temblores del 19 de septiembre de 2017, es probable que su comportamiento cambie en los meses siguientes cada vez que se encuentre en el lugar que experimentó tal acontecimiento.

- Conductas socialmente esperadas (específicas y genéricas). Son todas aquellas interacciones que los individuos ajustan con base en los criterios que una sociedad impone (explícita e implícitamente) y que esperan satisfagan. Es decir, se espera que la gente trabaje, que no grite en las bibliotecas, que nunca robe, etc. Estas prácticas convencionales son valoradas con criterios sociales específicos en un momento y lugar particular. Cuando no se satisfacen los criterios que se espera de una persona o un grupo, es cuando empezamos a decir que hay problemas en la vida cotidiana. Si alguien dice que pretende suicidarse, habrá gente que señale que la persona tiene un problema, ya que lo que se espera es que siempre luche por la vida.

- Competencia social en el ejercicio de dichas conductas. Las competencias tienen que ver con lo que una persona puede realizar, ya sea por la capacidad de experiencia (ya lo ha hecho) o porque en potencia lo puede hacer (condiciones biológicas y sociales para hacerlo). Las competencias sociales son aquellas que están enmarcadas y reguladas por criterios de la sociedad. Las capacidades pueden favorecen la efectividad de ciertas interacciones, por ejemplo, si alguien tiene muy poco manejo con instrumentos puntiagudos o punzocortantes es probable que si intenta suicidarse no lo logre.

- Propensiones e inclinaciones. Las propensiones aluden a los estados temporales de corta duración como los estados de ánimo (enojo, felicidad, tristeza), conmociones emocionales (intensa y temporal) o condiciones biológicas (migraña, mareos, etc.). Por ejemplo, estar deprimido puede favorecer a que alguien quiera suicidarse. Las inclinaciones se refieren a los gustos y preferencias de objetos o personas con las que nos relacionamos. Tanto las propensiones como las inclinaciones cumplen funciones disposicionales en el comportamiento psicológico.

- Tendencias. Se refieren a todas aquellas conductas que ha llevado a cabo una persona en el pasado y tienen efectos particulares. Generalmente, las identificamos como hábitos o costumbres. Decimos que una persona tiene tendencias suicidas cuando vemos que habitualmente toma demasiado alcohol y medicamentos cada vez que se deprime. 


\section{Personas}

Se refiere a los individuos que se relacionan directa o indirectamente en las interacciones del presuicida. En el caso del suicidio, la participación significativa de las personas que tengan relación interactiva con el presuicida. Para analizar el papel funcional de cada individuo participante se han propuesto los siguientes roles:

- Mediador de la interacción. Determina el tipo de interacción (nivel funcional) y regula la contingencia. La persona que cumple con la función de mediador estructura la situación presente. Por ejemplo, el líder de una secta religiosa es un mediador del comportamiento de sus seguidores, siempre y cuando modifique el comportamiento de estos últimos. Si el líder no logra el cambio en sus seguidores, entonces no puede identificarse como un mediador de interacciones psicológicas.

- Mediado. Aquel que es regulado por las acciones del mediador. El mediado se ajusta a la estructura contingencial que un mediador establece. Continuando el ejemplo anterior, los seguidores cumplirían la función de mediados en la medida en que modifican su comportamiento en función de lo que el líder hace y dice.

- Regulador de inclinaciones y propensiones. Una persona que tiene la función de regular inclinaciones es aquella que facilita las preferencias por objetos o personas del presuicida, como cuando la presencia de un familiar que es aficionado a los rifles, favorece el gusto del presuicida por este tipo de armas. Mientras que alguien que regula propensiones cumple la función de modular estados emocionales y biológicos, por ejemplo, en una reunión de trabajo la presencia del jefe puede generar que alguien experimente sensaciones similares a las que ocurren cuando se piensa en el suicidio.

- Auspiciador. Se refiere a aquella persona que con su comportamiento facilita las condiciones para que se den determinadas interacciones, sin que este auspiciador forme parte directa de la interacción.

Efectos

Los efectos hacen alusión a las consecuencias que se producen después de las interacciones psicológicas. Si bien, es cierto que está ampliamente documentado que las consecuencias son un factor relevante en la regulación de comportamiento, estas consecuencias forman parte del campo de contingencias, por lo tanto, no tiene mayor peso explicativo que los demás factores del campo.

En todo caso, el análisis de la interacción completa podrá determinar el peso real de las consecuencias y la orientación de sus efectos.

Son tres tipos de efectos los más frecuentes que se identifican en las interacciones psicológicas:

- Efectivos: cuando la actividad del presuicida afecta el comportamiento de otros (altera el sistema contingencial de otros).

- Inefectivos: cuando la actividad del presuicida no afecta la conducta de otros (no altera el sistema contingencial de otros).

- Afectivos: cuando la actividad del presuicida afecta la conducta del mismo (altera su propio sistema contingencial). En el caso del suicidio todos los comportamientos intencionales y consumados son afectivos. 
Ahora bien, algunas de las relaciones funcionales vinculadas con estos diferentes tipos de efectos para el análisis de cualquier comportamiento humano son las mismas relaciones para abordar las interacciones del presuicida, pero no las únicas ni necesariamente todas tendrían que ser analizadas:

- La actividad del presuicida y la forma en que afecta a otra(s) persona(s) significativa(s) en lo individual.

- La actividad del presuicida y la forma en que es afectada a otra(s) persona(s) significativa(s)

- La actividad del presuicida y la forma en que afecta indirectamente a aquellos que no la afectan.

- La actividad de otras personas entre sí y la forma en que afectan indirectamente al presuicida.

- La conducta del presuicida y la manera en que se afecta a su propia interacción previa al acto consumado.

Una vez identificados y descritos los factores de una situación microcontingencial procederé con el análisis de relaciones del presuicida para determinar el papel que juegan cada uno de ellos en los episodios psicológicos.

\section{Sistema Macrocontingencial del presuicida}

Se refiere al sistema valorativo que regula las relaciones que se dan a nivel microcontingencial. Es decir, todo comportamiento se encuentra envuelto en diversas prácticas sociales que rigen nuestras acciones en términos morales. Entonces, el sistema macrocontingencial se trata de un análisis en el cual el principal objetivo es evaluar la correspondencia entre relaciones microcontingenciales ejemplares y situacionales.

Las microcontingencias ejemplares se caracterizan por ser interacciones que explicitan la valoración de los modos sociales. Estas funcionan como modelos o ejemplos que van a regular el comportamiento individual y colectivo. ¿De dónde salen los criterios de valoración o quien los impone? Las prácticas valorativas las establece el grupo social en el que se interactúa. En el caso del suicidio, el ejemplar más conocido es cuando el grupo social establece que la vida es lo más importante como lo explicita la religión cristiana. Las formas de establecer estas normas pueden concretarse en prescripciones, indicaciones, advertencias, condicionamiento, sanción, prohibición, entre muchas otras.

Las microcontingencias situacionales son todas aquellas interacciones que están reguladas por las microcontingencias ejemplares sin que estén necesariamente presentes los criterios de valoración, por ejemplo, uno no sale desnudo a la calle porque hay reglas explícitas que regulan nuestra forma de vestir en función de la circunstancia social. No requerimos que todos los días nos digan que hay que salir vestidos. Los individuos nos apropiamos de un "deber ser" y un "no deber ser" que impone la sociedad para establecer armonía en la misma.

¿Cómo se relacionan estas dos microcontingencias, la ejemplar y la situacional, en el comportamiento suicida? Se relacionan como la correspondencia entre las dos microcontingencias en términos de lo que una persona cree (ejemplar) y lo que se hace (situacional). En este sentido, el control del suicidio se concretaría como la falta de correspondencia entre las microcontingencias, y en aquellas donde hay correspondencia es necesario eliminarlas para evaluar sus efectos.

Para ello, es necesario analizar mínimamente las siguientes relaciones:

- Identificación de la creencia o criterio de valoración para considerar un comportamiento suicida.

- Establecer criterios como "deber ser" o "no deber ser" del comportamiento suicida, esto es, criterios en términos morales. 
- Identificar las situaciones y las personas que explicitan los valores morales que dan contexto a las interacciones problemáticas y las no problemáticas.

- Delimitar las prácticas y creencias que establecen las personas que conforman la microcontingencia ejemplar.

\section{Génesis de las interacciones presuicidas}

Se trata del análisis de la historia interactiva del individuo, es decir, de la capacidad desarrollada por el presuicida en el pasado para interactuar efectivamente en situaciones que establecen ciertos requerimientos o resultados. No significa necesariamente que uno debe remitirse hasta la niñez del presuicida, aun cuando es posible que en ocasiones se requiera. La historia interactiva tiene una función disposicional en las interacciones presentes, esto significa que interviene de forma indirecta.

La génesis de las interacciones presuicidas se componen por los siguientes aspectos:

- Historia de las microcontingencias. Esta se refiere al origen de aquellas interacciones del presuicida que nos interesa. Dado que nadie se comporta al margen de sus experiencias pasadas, es necesario considerar las circunstancias en que iniciaron aquellas colecciones de interacciones que forman parte del ser psicológico del presuicida. También se requiere identificar la historia mediadora de la conducta, esto es, las funciones y disposiciones en el pasado de las personas significativas en las microcontingencias actuales.

- Estrategias de interacción. Se hace alusión a los tipos de situaciones que ha enfrentado el presuicida y el modo en cómo las ha afrontado. Por ejemplo, cuando alguien de forma frecuente lidia con gritos e insultos por parte de los miembros de la familia (situación familiar) y la manera en que ha respondido esta persona en dichas situaciones ha consistido en encerrarse en el baño y cortarse las venas de la muñeca (modo consistente de respuesta).

- Evaluación de competencias. Con base en los dos aspectos anteriores, podemos hacer el análisis de las competencias con las que cuenta el presuicida. La evaluación de competencias se da como el ejercicio funcional de conductas efectivas en diferentes contextos. El establecimiento de las competencias implica la disponibilidad de morfologías de respuestas que correspondan a las funciones microcontingenciales presentes.

\section{Análisis de control contingencial presuicida y aplicación de procedimientos}

Entonces, con base en la información obtenida en los análisis microcontingencial y macrocontingencial debemos elegir las variables que deseamos alterar para el control del suicidio. Por ejemplo, el cambio de la conducta en otros en las microcontingencias, promover opciones funcionales del presuicida o alterar la propia conducta del presuicida, etc.

¿Cómo logramos estas modificaciones en las interacciones del presuicida? Como ya lo he mencionado, toda historia interactiva de un presuicida es única y particular, por lo tanto, nunca podrán ocurrir dos suicidios iguales. Es probable que sean similares en su forma, pero jamás idénticas hablando psicológicamente. Esto significa que no hay técnicas o procedimientos ad hoc para el control del suicidio. La alternativa contingencial, inicial y momentánea, es utilizar las diversas técnicas disponibles para alterar todos los factores que deseamos, por ejemplo, ensayo conductual, desensibilización sistemática, manejo de contingencias, técnicas de autocontrol, entrenamiento asertivo, modelamiento y moldeamiento, entre otras. 
Es claro que varias técnicas se utilizan y fueron diseñadas para solucionar problemas específicos, esto como parte de la herencia del modelo médico salud-enfermedad. Dicho modelo supone que hay una variedad de procedimientos y técnicas específicas para la solución de problemas en contextos socialmente relevantes. Sin embargo, nos apoyaremos en estas técnicas de forma provisional para las intervenciones específicas a las características de las interacciones del presuicida. Entonces, ¿debemos utilizar técnicas derivadas de otros modelos teóricos?

Por un lado, gran parte de las técnicas de otros modelos teóricos surgen a partir de los procedimientos de laboratorio en los estudios de análisis experimental de la conducta en animales y humanos. Por otro lado, en el sentido estricto todas las técnicas son conductuales, pues todas están remitidas al comportamiento de los individuos. No hay que olvidar que la conducta es el referente empírico y metodológico con el que trabaja cualquier psicólogo, independientemente de su postura teórica.

Claro, el hecho de que todas las técnicas implican trabajar operativamente con diferentes aspectos de la conducta, no significa que todas deriven de la misma lógica ni se diseñen con los mismos propósitos. No obstante, mientras tengamos la claridad conceptual y teórica de lo que se quiere hacer, entonces su uso es válido. Esto es correcto siempre y cuando hayamos realizado un análisis con las categorías de sistema interconductual?

\section{Directrices para la construcción de un programa tecnológico del comportamiento suicida}

La cobertura de cualquier programa de investigación tecnológica varía en función del nivel de análisis científico que respalde dicha tecnología, además claro está, de los objetivos específicos que se pretenden. Los objetivos de investigación tecnológica de orientación interconductual que propongo cubren los siguientes problemas iniciales:

1. Desarrollo de instrumentos de evaluación del comportamiento suicida. No me refiero a la aplicación de pruebas psicométricas tradicionales. Como ya he argumentado, son limitados aquellos instrumentos que fueron construidos bajo supuestos falsos como es el dominante dualismo mente-cuerpo. Lo ideal es desarrollar instrumentos derivados de supuestos teóricos libres de errores conceptuales y lógicos.

2. Elaboración de técnicas de diagnóstico e intervención de control. Por desarrollo de técnicas de diagnóstico para el comportamiento suicida no me refiero necesariamente a lo utilizado en psicoterapias, intervención de modificación de la conducta, pruebas proyectivas u objetivas, etc. Más bien, me refiero a la elaboración de técnicas ad hoc para el comportamiento suicida del presuicida particular, esto quiere decir, que difícilmente estas mismas servirían para el diagnóstico de otro presuicida.

La intervención del control requiere, en principio, del uso de estrategias tradicionales para explorar e indagar acerca de los factores. Se espera que posteriormente se desarrollen varios intentos para construir procedimientos más sistemáticos que permitan abordar el suicidio de forma más fácil para su control.

3. Regulación y construcción de historias interactivas novedosas. Debemos construir una historia interactiva orientada a ejecutar dicho comportamiento y al mantenimiento de conductas que promuevan el suicidio. Se

$7 \quad$ Ciertamente, desde la formulación original de Kantor hasta hoy en día, no existen técnicas específicas derivadas del modelo interconductual. Sin duda, una tarea pendiente de los interconductistas es desarrollar procedimientos aplicados derivados exclusivamente del modelo de campo para la trasformación de problemas sociales. 
debe construir interacciones novedosas después de haber efectuado el correspondiente análisis contingencial para el control del suicidio.

Un aspecto importante de la propuesta de investigación tecnológica es que podemos servirnos de los estudios de prevención del suicidio para probar diversas hipótesis. Por ejemplo, se ha documentado ampliamente en la literatura la relación entre el suicidio y las adicciones. Se supone que el consumo de drogas potencializa el riesgo del suicidio. Habría que investigar en qué situaciones, con qué tipo de droga, pero, sobre todo, con qué historia interactiva particular. O bien, el alcohol funciona en ocasiones como mediador de los impulsos porque producen un estado ansiolítico y euforizante potencializando la agresividad, que favorece la aparición de conductas suicidas. Es decir, debemos experimental con los presuicidas con diferentes parámetros para comprobar nuestras hipótesis.

Por último y para cerrar este capítulo, quisiera decir algunas cosas acerca de la ciencia y la tecnología. Ninguna de las dos son modos de conocimientos neutrales o independientes frente al sistema económico, político y moral de la sociedad. Se desarrollan siempre en dirección de los intereses de quienes pueden y desean financiarlo. La ciencia y la tecnología son instituciones que están permeadas y reguladas por la matriz cultural vigente en un tiempo y espacio determinado. Esto significa que la ciencia no es de ninguna manera neutral en lo que refiere a su desarrollo y propósito. Al igual que cualquier modo de conocimiento, la ciencia no es completamente independiente de los factores culturales, por el contrario, su orientación en nuestros días está regulada por la lógica de la ideología capitalista.

Veamos el caso de la elaboración de medicamentos para la salud. La creación y producción de medicamentos desarrollados por los científicos depende no sólo de aquellas personas que los necesiten, sino también de su posible demanda global y de las retribuciones económicas que haya de por medio. Por ejemplo, es posible que exista una pequeña población que requiera de un medicamento particular para combatir un virus que está enfermando a los individuos. Sin embargo, dicha investigación encargada de elaborar el medicamento no se desarrollará si el número de personas que requiere dicha medicina no es lo suficientemente grande como para retribuir en términos económicos el trabajo científico. Con todo esto, quiero señalar que la tecnología es un producto más en el mercado de consumo y su desarrollo depende, entre muchas cosas, de las ganancias económicas.

Respecto a esto que menciono debo aclarar que las ciencias no se diseñaron para el beneficio de la lógica del mercado privado, por lo tanto, toda derivación tecnológica no debería de entrar en la lógica capitalista como valor de uso y valor de cambio. Obvio, resulta ingenuo pensar que las ciencias pueden desarrollarse al margen de las instituciones vigentes. Sin embargo, esto no significa que no se pueda revertir esta situación. Para empezar, no se debe de privatizar el conocimiento, por el contrario, se debe de divulgar e involucrar a la gente a participar en la ciencia y la tecnología por dos simples razones:

1. El conocimiento científico no debe quedarse en el interior de las paredes de los institutos y universidades. Tampoco debe quedarse en las revistas científicas y congresos especializados. Por el contrario, el conocimiento científico tiene que estar al alcance de todos los individuos que no forman parte de la comunidad científica. Lo más importante es que exista la posibilidad de que la ciudadanía se apropie de los saberes científicos.

2. Si de todo conocimiento científico se puede derivar tecnología, entonces esa tecnología también debe estar a disposición de todas las personas y no sólo de unas cuantas que estén en posibilidades de su acceso. De hecho, 
no sólo debe estar a disposición y beneficio para cada uno de nosotros de forma receptiva. ¿Qué quiero decir con esto? Que la tecnología no debe ser proporcionada siempre por alguien más (me refiero a los expertos) y menos si hay fines lucrativos de por medio. ${ }^{8}$ Por el contrario, cada persona debe de estar en la posibilidad de hacer uso de esa tecnología como algo propio, o sea, ser usuario de la tecnología sin beneficio económico que acentúe la división entre las clases sociales.

En pocas palabras, tanto el conocimiento científico como la tecnología deben estar al servicio de todos y no debe ser un instrumento para lucha de poder de clases sociales.

8 Esto nos compromete más si tomamos en cuenta que la mayoría de la investigación de calidad realizada en nuestro país está financiada con el dinero que se obtiene de los impuestos de todos nosotros. No debe de existir el uso de los recursos públicos si al final se utilizará con fines privados en lo que refiere al ámbito de la ciencia. 


\section{CAPÍtulo 6}

\section{Reflexiones en torno al control del suicidio}

Es una máxima sensata que los actos reprensibles pueden estar justificados por sus efectos, y cuando el efecto es bueno [...] el acto siempre está justificado

Nicolás Maquiavelo

Siempre hay razones para asesinar a un hombre. Por el contrario, es imposible justificar que viva

Jean Batiste Clamence (en La Caída de Albert Camus)

En este último capítulo expresaré algunas reflexiones personales en torno al control del suicidio y ofreceré las justificaciones necesarias para legitimar su aplicación fuera del ámbito científico o académico. Debe quedar claro que todo lo que exprese desde ahora no lo hago con base en criterios propios de la ciencia en psicología. Más bien, lo hago como una persona cualquiera que tiene una opinión de los eventos que ocurren en el mundo y, claro está, que dicha opinión del mundo está influida inevitablemente por diferentes circunstancias económicas, culturales y morales de una sociedad, además de las diversas experiencias de la vida personal de quien escribe.

Empezaré por recordarle al lector que cuando hablo del control del suicidio me estoy refiriendo a la manipulación deliberada de las variables que conforman las situaciones particulares en las que interactúa un individuo para desplegar esta forma de comportamiento. Ahora bien, ¿por qué utilizo la palabra "control" del suicidio y no las palabras "provocación" o "inducción" del suicidio? Porque con la palabra control quiero hacer énfasis en el objetivo que se pretende desde la ciencia en psicología. No debe pensarse de ninguna manera que se trata de un disfraz o un cambio de etiqueta con la que pretendo "suavizar" u ocultar el propósito.

Dicho esto, las preguntas inmediatas y obvias son las siguientes: ¿por qué aplicar el control del suicidio en la vida cotidiana? y ¿con qué finalidad le interesaría a alguien controlar el suicidio en otro? Seguramente, quienes hayan tenido una experiencia de suicidio de un ser querido o aquellos que hayan intentado suicidarse nunca le desearían tal 
vivencia a otra persona. O bien, se puede decir con toda seguridad que controlar el suicidio en otro es un delito y va en contra de los derechos humanos universales.

En realidad, lo que pretendo hacer es ofrecer una visión del control del suicidio que puede tener diversos beneficios en nuestros días. ¿Cuáles? Desde mi punto hay dos aspectos a su favor, sin ser los únicos posibles. El primero de ellos tiene que ver con el potencial de generar nuevos planteamientos para la ciencia. Si bien, ya he hablado respecto a este punto, siempre ha sido refiriéndome en el "interior" de la ciencia y no desde la mirada de "afuera". El segundo aspecto, y que me interesa desarrollar ampliamente, es su utilidad como una herramienta para la transformación de una sociedad más justa. Ambas ideas las desarrollaré en lo que resta del capítulo.

\section{La generación de conocimiento mediante el control del suicidio}

El lector seguramente se preguntará o cuestionará varios aspectos de índole moral y ético en torno a la propuesta del control del suicidio: ¿con qué derecho o con base en qué criterio podríamos controlar el suicidio en otros?, ¿quiénes somos para controlar cómo y cuándo alguien debe cometer suicidio?, ¿̇en qué personas deberíamos controlar el suicidio? En otras palabras, ¿ con qué autoridad incurrimos de esta forma en la vida de alguien? Sin duda, pretender responder satisfactoriamente a estas preguntas es una tarea difícil por todas las implicaciones. Sin embargo, me aventuraré a responderlas y justificarlas con base en los siguientes dos puntos: 1) el objetivo o propósito nos da la autoridad y 2) contamos con las herramientas teóricas y metodológicas, para poder llevarlo a cabo.

Respecto al primer punto quisiera recuperar el pensamiento del florentino Nicolás Maquiavelo en su obra El príncipe. Me interesa la tesis que sostiene que para alcanzar nuestros objetivos podemos (mejor dicho, debemos) emplear cualquier medio. Considero ejemplar esta línea de pensamiento llevada a la práctica para los progresos de la ciencia. Cito en extenso un extracto que escribió Maquiavelo que considero representativo de esto que menciono:

Aún más: creo que es próspero aquel que armoniza su modo de proceder con los caracteres de los tiempos. Y que, de igual modo, no es próspero el que tiene un proceder discordante con los tiempos. Porque es posible apreciar que los hombres se comportan de modo variable para alcanzar el fin que cada uno se propone, vale decir gloria y riquezas. Y uno actúa con precaución, otro con ímpetu; uno con violencia, otro con astucia; uno con paciencia, otro con impaciencia. Pero todos, con diversos modos, pueden alcanzar el propósito indicado, y hasta poder verse cómo de dos personas prudentes, uno llega a su objetivo y el otro no. Del mismo modo, otras dos personas pueden prosperar igualmente con actitudes distintas, siendo una de ellas precavida y la segunda impetuosa. Y la causa está solamente en la cualidad de los tiempos, que se conforman o no con su modo de proceder. De aquí surge lo ya dicho: dos personas, actuando de modos distintos, consiguen el mismo resultado, y de dos personas que actúan del mismo modo, una alcanza su propósito y la otra no. (XXV, pp. 155-156)

La tesis principal de esta obra es conocida por todos de manera coloquial como "el fin justifica los medios". Si bien, es cierto que Maquiavelo se refiere a un asunto de política y la forma en cómo se debe gobernar, considero que la aplicación de la lógica de dicho pensamiento en el ámbito de la ciencia puede beneficiar en mucho en la psicología. 
¿Por qué creo esto? Porque si el fin es lícito, en nuestro caso, comprender el fenómeno conductual suicida, entonces también los medios son lícitos, aquí planteo al control del suicidio. No me cansaré de repetir que la propuesta de controlar el suicidio es con fines científicos para la generación de conocimiento y, posteriormente si se desea, se esté en mejores condiciones intelectuales de elaborar tecnología para la prevención del suicidio. En este sentido, debe entenderse a la tecnología como un puente entre el conocimiento y el desarrollo de la sociedad, no como el fin de sí mismo.

Respecto al segundo punto que mencioné, resulta obvio pensar que, si tenemos la claridad conceptual, teórica y metodológica para llevar a cabo el control, entonces estamos en las condiciones de hacerlo y no hay ningún impedimento para no proceder. Lo hacemos porque podemos. Sin duda, de primera impresión pareciera ser una posición autoritaria y poco justificable. No obstante, el lector no podrá negar que el control del comportamiento suicida se nos presenta como una posible alternativa de investigación cuyo único problema para lograrlo radica en la condición necesaria de tener ese poder para aplicarlo.

Pero, ¿a qué me refiero con el poder? El poder tiene muchas formas, pero de manera general se entiende como las condiciones materiales, intelectuales y de relaciones sociales que permiten cumplir los objetivos que uno se proponga. Si no se tiene ese poder para alcanzar sus propósitos, entonces de nada sirve lo que hagamos por mucho que nos esforcemos. Uno debe de crear o generar ese poder necesariamente. Respecto al uso del poder y la autoridad quiero citar el punto de vista del filósofo social Friedrich Engels (1966), quien decía:

¿No han visto nunca una revolución estos señores? Una revolución es, indudablemente, la cosa más autoritaria que existe; es el acto por medio del cual una parte de la población impone su voluntad a la otra parte por medio de fusiles, bayonetas y cañones, medios autoritarios si los hay; y el partido victorioso, si no quiere haber luchado en vano, tiene que mantener este dominio por medio del terror que sus armas inspiran a los reaccionarios. (p. 397)

Es claro que Engels se refiere a los medios autoritarios en movimientos sociales, y sería un grave error descontextualizar sus escritos. Sin embargo, esta lógica puede aplicarse perfectamente al asunto que me interesa aquí: controlar el suicidio como medio de afectación en el comportamiento individual.

Por otro lado, el pensamiento platónico proporciona una idea que empata perfectamente con todo lo que he mencionado. Platón nos dice, en su obra La República, que el poder se entreteje con el conocimiento y el saber. El saber siempre va ligado a la idea del Bien, porque es el objeto más adecuado para el alma, la perfección y verdad de las cosas. El Bien es el conocimiento y, por consiguiente, el mal es la ignorancia. Así, Platón creía que sólo aquellos que manejan el saber deben de ejercer el poder, nadie más. Por tanto, quien sabe más tiene que gobernar, pues es quien tiene la posibilidad de acceder a la verdad. Aquella persona que tiene el conocimiento le corresponde el poder, los más sabios tienen mayor autoridad.

Si adecuo este planteamiento para los propósitos del control del suicidio quedaría de la siguiente forma: si nuestro fin es el conocimiento y la comprensión del comportamiento suicida mediante la búsqueda de la certeza y la verdad, entonces estamos haciendo un bien que podemos ejercer con autoridad. 
Entonces, estos aspectos particulares de los pensamientos de Maquiavelo, Engels y Platón, considero que pueden ayudar a superar las cuestiones éticas y metodológicas cuando se tiene por objetivo comprender este fenómeno. Sin embargo, antes de incurrir en dilemas éticos y morales no está por demás recordar y reflexionar todos los actos que se han hecho a lo largo de la historia de la humanidad justificados para diferentes propósitos.

Por ejemplo, en la investigación médica existen numerosos casos en los que se han violado los derechos humanos bajo la justificación de la búsqueda de soluciones o curas para las enfermedades. Un ejemplo que ilustra lo anterior es el experimento de científicos estadounidenses sobre las infecciones venéreas llevado a cabo en Guatemala durante los años cuarenta. El experimento consistió básicamente en infectar a reos, pacientes psiquiátricos y prostitutas de enfermedades venéreas como la sífilis, gonorrea y otras más mediante inoculación directa, sin consentimiento alguno. Todo esto se realizó con la finalidad de validar la efectividad de nuevos antibióticos de penicilina y otros tratamientos. A pesar de la falta de ética en la forma de proceder, fue claro que este estudio aportó evidencia empírica que sustentó la efectividad de fármacos de los cuales nos hemos beneficiado para nuestra salud.

Siguiendo esta misma línea, considero que controlar el suicidio para fines científicos es una postura humanista, en el sentido más amplio, por las siguientes tres razones principales:

1. No hay nada más humano que ver por todos y no por unos cuantos. Provocar el suicidio de manera rigurosa en unas cuantas personas podría generar un conocimiento que beneficiaría al resto. Me pregunto, ¿acaso no deberíamos dejar el egoísmo y la ética para comprender a profundidad el comportamiento suicida para prevenirlo?

2. Es una postura humanista porque plasmo tales ideas con base en una lógica racional y sistemática, siendo estas características distintivas del ser humano.

3. El control del suicidio depende de quien ejerce el control, contra quién y con qué objetivos. Particularmente, propongo que se realice con fines de conocimiento, aun cuando podría ser útil para otros propósitos de transformación social.

Para concluir esta parte, quiero señalar que ejercer control del suicidio implicaría en la mayoría de las ocasiones algún tipo de comportamiento valorado como violento. Es difícil justificar la violencia y aceptarla en nuestra sociedad como si se tratara de cualquier otro tipo de convivencia entre personas. Sin embargo, es posible que ésta tenga un carácter positivo en función de la situación, como demostraré a continuación.

\section{Control del suicidio y violencia}

Existe la creencia popular, o de sentido común, de que promover el suicidio en un individuo es un acto de violencia porque implica ejercer o imponer algo en contra de la voluntad de otro. La forma particular en que se ejerce la violencia hace de ella algo que queramos evitar siempre, de ahí su connotación negativa. Cuando hablo de violencia me refiero a ésta en cualquier situación (familiar, laboral, económica, matrimonial, escolar, etc.) y en cualquiera de sus formas (física, verbal o ambas) que ocurre generalmente hacia otro(s). La violencia transgrede y por eso la consideramos, con toda justeza, injustificable desde el punto de vista moral. 
Sin embargo, es posible elaborar una distinta visión de la violencia. Voy a demostrar que una de sus caras que resulta útil e indispensable para cierto progreso intelectual y que en el caso particular del control del suicidio no es posible condenarla de forma tan tajante.

Para empezar, quisiera recordarle al lector que la violencia siempre ha estado presente en la historia de la humanidad. Más aun, algunos académicos e intelectuales han llegado a afirmar que la violencia es consustancial no sólo al ser humano desde sus orígenes, sino a la gran mayoría de las especies del planeta ${ }^{1}$.

Cuando se trata del comportamiento suicida se le considera como un acto de violencia contra uno mismo ya que se orienta a la autodestrucción. De este modo, si uno controla el suicidio en otro podría considerarse como un acto aún más violento y condenatorio. No obstante, es inadecuado etiquetar a la violencia como "mala" o "dañina" por sí misma como si esta fuese su naturaleza.

En primer lugar, hay que decir que la violencia indudablemente está sujeta a distintas valoraciones como cualquier acción humana. Es por eso que más que hablar de "la" violencia tendríamos que referirnos a "las" violencias, pues se expresa de distintas formas tales como la violencia física, psicológica, económica, laboral, familiar, etc. Lo que ocurre es que violencia casi siempre va a acompañada de dolor y sufrimiento, por eso la valoramos como algo negativo.

Pero es claro que para poder predicar de "buena" o "mala" a la violencia, de "correcta" o "incorrecta", "positiva" o "negativa", depende de por lo menos cuatro aspectos: 1) el fin o propósito que se persigue al ejercerla, 2) las personas quienes la ejercen, 3) las personas contra quienes se ejerce y 4) de las consecuencias de dichos actos. De lo contrario, solamente se estará haciendo un prejuicio sin sentido. Entonces, sostengo que es falsa la afirmación o creencia popular de que la violencia es intrínsecamente mala. Resulta ser un absurdo intentar cualificar a la violencia con adjetivos de "maldad" al margen de la situación de quién la ejerce, contra quién se ejerce y sobre todo con qué fines. Por eso, nuestra responsabilidad intelectual está en otorgarle a la violencia el estatus que le corresponde en la vida cotidiana del ser humano, en especial cuando se trata del suicidio.

Los actos violentos "positivos" lo son en la medida en que estos pueden ser útiles, y necesarios en ocasiones, para la resolución de conflictos. Por ejemplo, los esclavos o aquella gente reprimida en una sociedad que no tienen más armas que la misma violencia para cambiar sus condiciones. En este sentido la violencia puede ser un instrumento eficaz para los más desprotegidos.

De todo lo anterior, sostengo que si alguien comete suicidio o si se controla el suicido en éste, puede considerársele como un acto violento, pero no negativo sin tomar en cuenta la situación general.

Sin duda, la violencia tiene su lado negativo y desagradable que la mayoría queremos evadir. Sin embargo, habría que ser justos y destacar también su lado positivo haciendo uso de ella cuando los propósitos estén orientados al progreso intelectual.

1 Debemos tomar con cautela esta afirmación pues le ha servido a muchos políticos y líderes mundiales como justificación perfecta para desatar guerras. Incluso algunos piensan o han sugerido que sin violencia no habría historia universal. Considero que esto no es más que un falso determinante que algunas personas pertenecientes a la alta clase económica necesitan que las naturalicemos para justificar los actos bélicos. Sin embargo, esto es un falso condicionante, tal como decía Jean Paul Sartre: "Somos libres y elegimos la guerra o no". 


\section{Control del suicidio como instrumento de justicia y el ámbito jurídico}

Imagine el lector la siguiente situación que bien podría ocurrir en cualquier parte del mundo: una madre es víctima del secuestro de su hijo (el secuestrado también es víctima, obvio) y este último es torturado y abusado sexualmente para después ser brutalmente asesinado. Es totalmente comprensible que la madre exija justicia por aquel aborrecible y reprobable hecho. Incluso, la madre podría pensar en algún tipo de venganza por propia mano, en especial si el sistema judicial no sirve como debiera. De hecho, la venganza es un tipo de justicia, primitiva si se le quiere pensar así, pero al fin y al cabo es justicia ${ }^{2}$.

El control del suicidio podría ser utilizado como un instrumento para hacer justicia a todas aquellas personas que han sido víctimas de situaciones de desigualdad por parte de otros. ¿A qué me refiero con esto? A que es posible "limpiar" la sociedad y hacer justica sin recurrir al asesinato. Debe quedar claro que en el control del suicidio no se está matando a nadie pues se trata de un suicidio, es la propia persona quien decide en última instancia quitarse la vida, nadie más.

No faltarán aquellas personas que podrían objetar, con base en ideas irracionales y sentimentalismos absurdos, afirmando que la venganza no es algo bueno y que en realidad lo único que se consigue con eso es perjudicar a la comunidad o sociedad, pero sobre todo uno mismo es el más perjudicado. Este tipo de personas (en su mayoría religiosos cristianos) ofrecen como alternativa la calma, paz interior y el perdón de aquellos que nos perjudicaron. Pero habría que preguntarnos, ¿siempre hay cabida para el perdón? ¿acaso todo es perdonable? La respuesta es no. Mucho se ha escrito acerca de la venganza y se le ha dado la característica particular de aquellos individuos resentidos o cobardes que toman represalia cuando les hacen algún daño. Sin embargo, al igual que en el caso de la violencia, es claro que cualquier connotación negativa de la venganza depende de la situación para considerársele así.

Pensemos de nuevo en el caso de la madre que es víctima del secuestro de su hijo. ¿Qué pasaría si se le pidiera a esta mujer que perdone a la persona que torturó y abusó sexualmente de su hijo? Muy seguramente esto lo tomaría como un insulto. Hay cosas que simplemente no se pueden perdonar. Puede haber justicia sin que esto signifique que exista un perdón de por medio. El perdón se relaciona con la justicia en un sentido particular: para que el perdón exista es necesario primero que haya justicia, no debe pensarse que son sinónimos. Soy un partidario indiscutible de la justicia y dignidad humana, y en ese sentido, la venganza controlando el suicidio en otros puede ser una forma de justicia. ¿En qué sentido se vuelve justicia? Si la justicia significa dar a cada uno lo que le corresponde o lo que le pertenece, entonces la venganza se justifica al estar encaminada a la igualdad en aspectos sociales y psicológicos. Más adelante volveré a tratar este asunto.

Por otro lado, se ha expresado mucho respecto a la muerte de otros y siempre se prefiere la muerte del otro que la propia. El miedo a la muerte está presente en la mayoría de las personas. El no saber cuándo va a llegar es motivo de miedo, de ahí que se prefiera morir en calma y sin que uno se dé cuenta. Todos estamos condenamos a la muerte.

2 Coloquialmente hacemos referencia a diversos tipos de justicia: legal, penal, divina, social, deportiva, etc. Aquí me refiero al término justicia en el sentido más coloquial y no en términos de legalidad del ámbito jurídico. Me refiero a aquella justicia que no abarca necesariamente lo establecido por las leyes jurídicas de la sociedad como la distribución de recompensas y los castigos. En la novela El conde de Montecristo de Alexander Dumas se puede encontrar la forma de justicia a la que me refiero en términos de venganza. 
Todos marchamos en el mismo camino, cada uno a diferente ritmo y con distintas compañías, pero al fin y al cabo al mismo lugar. Es como una cascada donde no importa donde vaya cada gota o pez en el agua ni a qué velocidad, al final caerán junto con todo al precipicio, pues todos tienen el mismo trayecto.

Sin embargo, cuando uno prefiere la muerte de otra persona en lugar de la propia, también se le piensa de otra forma: se le desea la muerte por méritos ganados a pulso, por razones tan variadas como aquellas morales, éticas, legales, religiosas o las más importantes, las personales. No obstante, uno no puede matar a cualquier persona sin recibir consecuencias permeadas por las leyes, la moral y demás. Matar a alguien en nuestra sociedad está penado y valorado como un acto de barbarie. Pero más que un temor por los castigos legales, el verdadero castigo es la condena de remordimiento de conciencia. No hay peor castigo que aquel remordimiento y arrepentimiento inútil de nuestros actos. ¿Qué alternativa tenemos para llevar en acto la muerte de alguien sin remordimiento de conciencia alguno o castigos legales? Una solución justa y elegante es el control del comportamiento suicida.

Pero, ¿por qué no simplemente matar a aquella persona que merece morir? Es verdad, cuando nuestra muerte llega en manos de otros se convierte en uno de los actos más terroríficos del hombre contra el hombre. No hay peor muerte que una muerte embargada por otro, una muerte expropiada. La muerte se nos presenta continuamente como aquello que estructura todas nuestras posibilidades de ser, la expropiación de la muerte por parte de otro se convierte en una de las formas más nefastas de sometimiento. Robarle el fin de la vida a alguien es una de las formas más acabadas de la deshumanización.

Parece entonces que se frustra nuestro deseo por matar al otro cuando se trata de hacer justicia. De hecho, tal parece estar justificada "humanamente", ética o moralmente la imposibilidad de asesinar a alguien. ¿Habría alguna alternativa para quitar dicha imposibilidad de robarle a alguien la vida que simplemente ha cometido actos terribles? Tal vez una alternativa sea inducir al suicidio a aquella persona.

Pero, ¿acaso la justicia jurídica y penal no puede reparar los actos aberrantes que se cometieron? Esta pregunta y su tentativa respuesta son de suma importancia en la medida en que la justicia tiene que ver no sólo con las bases mismas de regulación de nuestra sociedad, sino también con aspectos que escapan al sistema jurídico, tales son los asuntos personales. Aun cuando la justicia jurídica y penal pudiera abarcar tales aspectos, ¿por qué debería quedar en la decisión de lo justo en alguien más? ¿no sería más congruente en ocasiones la justicia por mano propia? Son bastante discutibles las preguntas anteriores.

Mi posición al respecto es la siguiente: dar el perdón u ofrecer disculpas no son de ninguna manera formas de hacer justicia. Tiene que existir una simetría o correspondencia entre los actos y sus consecuencias. Hay acciones penales que nunca van a reparar los actos cometidos. No existe medida humana para una gran cantidad de sucesos.

Ahora bien, cuando se trasladó el tema del suicidio del ámbito de salud al sistema penal, éste fue sujeto a nuevas formas de sometimiento para su tratamiento. El sistema penal estableció penalidades a los suicidas y/o a las personas que intentaban suicidarse. Más allá de las razones históricas del porqué se castiga el suicidio en el ámbito legal y jurídico, como vimos en el primer capítulo, es necesario preguntarnos cuál es la justificación actual que impide que cometamos suicidio. Algunos especialistas arguyen que la vida es objeto y sujeto de derecho, por lo tanto, el derecho a la vida por su alta calidad debe de quedar amparado por las normas éticas y por prescripciones jurídicas de la sociedad (Marchiori, 2000). 
Entonces, en la medida en que la vida está sujeta a las leyes jurídicas, éstas nos obligan a responder con responsabilidad a ella bajo ciertos criterios.

¿De qué responsabilidad se trata? De la responsabilidad moral. Acerca de esto, alguna vez dijo Aristóteles: "Una persona es moralmente responsable si con el conocimiento de las circunstancias y en la ausencia de compulsión externa, deliberadamente escoge cometer un acto específico" (2010). Hoy en día se mantiene de forma parcial lo dicho por Aristóteles en nuestros sistemas jurídicos pues reconocen, de una u otra manera, que la libertad de las personas trae consigo la condición de responsabilidad de todo acto cometido. No obstante, desde hace varias décadas se sostiene que la ignorancia o falta de conocimiento no exime a nadie de la ley, es decir, el desconocimiento de la ley no sirve de excusa.

En las leyes del Derecho Mexicano para que un acto delictivo se le califique como tal, debe reunir las características de punibilidad, antijurídica y culpabilidad. Ésta última, la culpabilidad, se refiere al conocimiento de la naturaleza del acto y la intención culpable. La presencia de un trastorno o enfermedad mental que prive al individuo de capacidades racionales en el momento del acto es causa de exclusión del delito. En otras palabras, si un individuo no tiene la capacidad de comprender el carácter ilícito de la acción, entonces es incapaz de distinguir lo bueno de lo malo, lo correcto de lo incorrecto. En estas condiciones no hay castigo legal.

Ahora bien, ¿qué hay de la relación entre el control del suicidio y las normas legales? Provocar el suicidio en una persona está penado y es considerado como un delito grave, posiblemente de homicidio involuntario ${ }^{3}$. De hecho, inducir a una persona al suicidio significa "crear" una voluntad del tipo suicida en donde antes no estaba. Al hacer esto, se incurre en un delito independientemente de que la persona se suicide o no. Se induce con conocimiento e intención de culpable.

Me propongo a rebatir los posibles argumentos legales que podrían condenar el control del suicidio. La forma en que refutaré dichos argumentos será con base en la lógica, es decir, desde la coherencia del discurso de forma sistemática.

Entonces, lo primero que hay que entender es que la instigación del suicidio difiere del suicidio asistido porque en el primero se utilizan, dirían algunos expertos, "medios subjetivos" que logran crear la voluntad del suicidio, por ejemplo, los consejos, engaños, promesas, etc. (Marchiori, 2000).

Pero ¿qué son los medios subjetivos? Tradicionalmente se han caracterizado de dos formas principales:

1. Como mensajes subliminales. Se trata de un tipo de información oculta que tiene efectos en la conducta de forma inadvertida. Es un mensaje en forma oral o escrita, a través de un dibujo, etc., que posee un propósito

3 El lector no debe de olvidar que las leyes de cualquier sistema jurídico en el mundo no son más que elaboraciones que hacemos los individuos dentro de una sociedad, por tanto, son modificables y de ninguna manera son una serie de reglas inherentes a la naturaleza humana misma. Todas las leyes son creadas para el beneficio de un grupo de personas con gran influencia en la política y economía. Entonces, se debe comprender que aun cuando la ley prohíba o castigue algún tipo de comportamiento, ésta no deja de ser una regulación de las prácticas sociales de los individuos que son la expresión ideológica de una clase social. 
específico, y es subliminal porque tiene información que se transmite por debajo del umbral de la conciencia de otras personas para modificar la conducta 4 .

2. Como un contacto indirecto. Esto quiere decir que no hay necesidad de algún tipo de instigación física aparente, es decir, que sólo es posible su ocurrencia entre seres lingüísticos, pues se requiere del lenguaje para hacer contacto con ello. Por ejemplo, los chistes de doble sentido.

Los consejos, engaños, promesas, órdenes, etc., son lo que en términos de la teoría de la conducta podríamos, en ocasiones, ubicarlos como comportamiento sustitutivo, siempre y cuando exista una mediación referencial. En este sentido, todos estos medios son comportamientos verbales inaparentes de naturaleza funcional.

Si los discursos de las personas como "medios subjetivos" tienen la efectividad de modificar el comportamiento aconteciendo por debajo de la experiencia consciente, entonces habría que decir con justeza que todos hacemos uso de ellos en cualquier situación de la vida cotidiana: con la pareja, amigos, enemigos, el político con el pueblo, el jefe con el empleado, etc. Toda la industria del mercado de consumo constantemente regula nuestros actos a través de estos supuestos mensajes subliminales, por ejemplo, en la publicidad de refresco, de alcohol, ropa, suplementos alimenticios, etc.

No faltará quien diga que no es lo mismo que nos induzcan por estos medios a consumir un refresco a que nos induzcan de la misma manera a suicidarnos. A lo que yo les preguntaría a todos los que piensan así: ¿por qué no es lo mismo?, ¿en qué radica la diferencia? ¿acaso es diferente porque en un caso se atenta contra la vida y en el otro no? Si es por esta razón habría que ser honestos y decir que las muertes por obesidad gracias al consumo de refrescos son mucho mayores que el número de suicidios. De hecho, no sólo los refrescos, esto podría aplicar también para todo tipo de productos que se consumen en el mercado como las bebidas alcohólicas.

Por ejemplo, la industria del vestido que se encarga de imponer y establecer modas muy particulares en el uso de la vestimenta tendría gran parte de la responsabilidad de que una gran parte de jóvenes anoréxicas mantengan muchas de las prácticas alimenticias que empobrecen su salud con el único fin de lucir ropa de talla cero que tanto se promociona. O bien, la industria del cigarro debería ser culpable de una gran cantidad de muertes vinculadas con cáncer y múltiples enfermedades respiratorias y psicológicas. De hecho, las tasas de muertes tanto de la anorexia como del consumo de cigarro son más altas que la de los suicidios.

Pero, ¿por qué si existen diversas industrias que atentan contra la vida no son sancionadas o eliminadas? Que esto no se valore como una amenaza obedece a tres razones: generalmente los efectos son lentos, pasivos y la ley lo permite bajo diferentes rubros. Todo se esconde bajo un disfraz de lo que está bien y la aceptación social.

4 Desde la teoría de la conducta, los supuestos mensajes subliminales no son más que interacciones psicológicas que ocurren en un nivel funcional contextual. Esto quiere decir que diversos segmentos de estímulo adquieren las propiedades de otros segmentos de estímulo, de tal forma que las respuestas del organismo ante los estímulos son interacciones contextualizadas. En realidad, ningún estudio serio sostiene la idea de información oculta en las cosas y que el cerebro (o mente) la asimila al margen de nosotros. Simplemente absurdo (Beatty y Hawkins, 1989). 
Regresando al tema de la instigación del suicidio, se supone que esto ocurre cuando la persona se da muerte a sí misma por causa de la inducción o incitación de otra persona, que es precisamente lo que pretendo con el control del suicidio con propósitos de la ciencia. Entonces, quien induce es considerado como culpable pues suponen que el suicida no hubiera hecho tal acto sin la participación de este instigador y es aquí donde está el problema central de todo: el suicidio no se hubiera concretado sin la intervención del otro que realiza a través de los medios "subjetivos".

Se castiga penalmente al que instiga o controla el suicidio porque para lograrlo debe de conocer de antemano la situación emocional y las ideas de muerte del suicida, de ahí que la instigación del suicidio sea un comportamiento punible: es intencional y determina que el individuo que instiga provoque la muerte en otro.

Sin embargo, lo anterior puede ser replicado fácilmente pues se suele ver al suicida como una víctima independiente de sus actos, como si fuera una persona pasiva que sólo recibe lo que hay en el entorno sin poder operar en el mismo para cambiarlo. Caracterizar las acciones del suicida de esta manera implica restarle o quitarle su responsabilidad a cada uno de los acontecimientos de su vida. Entonces, hay dos posibles lecturas:

1. Si le quitamos la responsabilidad de su acto al suicida, entonces lo mismo debe aplicar para el instigador, es decir, debemos restarle responsabilidad a quien controla el suicidio porque los principios aplican de la misma forma para los dos.

2. Si no le quitamos de su responsabilidad, entonces es claro que es la propia persona quien en última instancia tiene la decisión de suicidarse o no. Esto significa que no hay espacio para culpar a nadie más, cada uno es el único responsable de sus actos.

Es claro que no hay un único factor determinante en todos nuestros comportamientos, entonces esto nos permite otorgar la responsabilidad a quien le corresponde: al suicida. Cualquier individuo puede llegar a suponer que al poner las condiciones, elementos, factores y/o las circunstancias para controlar el suicidio en otro se le está guiando sin opción alguna a consumar dicho acto. Debe quedar claro que no se está matando a nadie. Nada que hagamos hacia los demás va a determinar que el individuo tome la determinación de suicidarse. Si se piensa lo contrario, es decir, que participamos como los únicos responsables para que alguien se suicide, entonces habría que ser justos y saber que no somos los únicos culpables: la familia, las ideologías, la economía y las instituciones también son responsables.

Ahora bien, la doctrina penal nos señala tres puntos característicos de la instigación al suicidio: 1) la instigación es un comportamiento intencional doloso, 2) la instigación implica, en la mayoría de los casos, la utilización de medios subjetivos, y 3) la instigación consiste en determinar a otra persona a la acción destructiva, al intento suicida y/o suicidio. Estos tres puntos tienen limitantes para probarse. Primero, es ambiguo y difícil determinar una auténtica intencionalidad con base en hechos, porque nos enfrentamos a la difícil tarea de establecer su orientación, ya sean psicólogos o abogados. Pensemos por un momento en aquellos libros autodidácticos que tienen por objetivo instruir el aprendizaje, por ejemplo, en el uso de la computación y el internet. Si alguien aprende su buen manejo y con base en ello se dedica al hackeo de programas cibernéticos, entonces ¿deberíamos culpar al escritor por formar hackers? Si la intención del libro no era promover que la gente se dedicara al hackeo de programas, pero el conocimiento aprendido lo posibilita, ¿habríamos de emancipar al escritor de su texto o las intenciones de quien lee? Si sostenemos que el libro es de alguna manera un instigador para diferentes manejos computacionales, incluyendo el hackeo aun cuando no 
lo explicite, entonces muchos de nosotros tendríamos que estar tras las rejas en la cárcel por diversas actividades que hacemos y contribuyen a esto.

Hay que hacer una diferencia entre la instigación al suicidio y la ayuda al suicidio. La supuesta "ayuda" consiste en proporcionar elementos materiales concretos para llevar a cabo el suicidio de otra persona, por ejemplo, la entrega explicita de una pistola, veneno o un cuchillo, otorgada intencionalmente. Pero, evidentemente se debe de distinguir cuando una persona incurre en este tipo de "ayuda" de cuando no, pues, yo podría entregarle a alguien un par de agujetas y con ello un arma en potencia. Cualquiera se puede suicidar ahorcándose con casi cualquier cosa; agujetas, corbatas, cargadores, sábanas, cuerdas, alambres, telas, incluso con los propios pantalones. Claro, no es lo mismo una pistola que una agujeta, sin embargo, en potencia ambas cosas pueden servir para cumplir el mismo objetivo. De hecho, con el par de agujetas se tiene una mayor posibilidad de que las personas se suiciden (o maten a otro) que con una pistola que tiene un número finito de balas.

Entonces, ¿cómo debemos considerar la participación de ayuda o instigación al suicidio? No hay respuesta clara. Por ejemplo, si alguien se le ocurre contar un chiste o hacer un comentario de mal gusto, pero sin la intención de ofender a alguien, y resulta que alguna persona depresiva al oír el chiste o comentario se suicida porque fue "la gota que derramó el vaso", ¿podría tratarse de instigación, ayuda o participación en el suicidio? ¿o ninguna de estas? El contexto, la historia de cada uno de los involucrados, el tipo de relación, entre muchos otros aspectos, nos podrán arrojar elementos para poder hacer una mejor lectura.

Desde una simple agujeta, un lazo para tender la ropa, las mangas de alguna sudadera, la correa del perro, hasta la ingesta de sustancias (medicamentos, concentrado de limpieza), incluso hasta el propio cabello ${ }^{5}$. Incluso las personas podrían llegar a inventar formas novedosas de suicidio en función de la rapidez e intensidad de dolor. Los objetos utilizados para privarse de la vida son variados y casi infinitos, todo con tal de dejar de existir y sin importar el cómo.

\section{El bien moral y la responsabilidad en el suicidio}

¿Controlar el suicidio es un acto de bien o de mal? Se puede responder desde diversos puntos de vista. Nuevamente me apoyaré en el pensamiento filosófico de Platón para delinear mi posición. Una buena persona, sostenía Platón, es lo que un ser humano tiene que hacer por naturaleza y eso es ni más ni menos que pensar. Toda acción nuestra supone que hacemos lo mejor para nosotros. Por ejemplo, si hago ejercicio es porque supongo que es lo mejor para mí, porque me gusta, me mantiene saludable, me hace estético y atractivo el cuerpo para el sexo opuesto, me distrae de los problemas diarios, etc. Lo mismo ocurre para cualquier actividad que realicemos. Si decido suicidarme es porque considero que es lo mejor, ya sea para terminar con una tortura, porque no le encuentro sentido a nada, por lo que sea. No existe acto que hagamos que no suponga que es lo mejor. Puede ser que lo que hagamos no coincida con lo demás, pero eso no significa necesariamente que sea incoherente o sin sentido.

$5 \quad$ En la mitología griega, la reina Yocasta se suicidó ahorcándose con una trenza larga de su propio cabello, esto al enterarse que era esposa y madre del rey Edipo 
Supongamos que usted trabaja en una empresa que lo explota laboralmente 15 horas al día en una actividad muy pesada y recibe a cambio un miserable salario que apenas le alcanza para vivir. Si usted no renuncia es porque considera que es preferible soportar eso en lugar de estar desempleado, o porque no ha encontrado otro trabajo, o tal vez considera que así es la vida, o porque lo obligan a ir, lo que sea. Podrían ser muchas las causas (excusas en realidad). Lo único que importa es que cada día que usted regresa a trabajar a la misma empresa está reafirmando que es lo mejor que puede hacer. Si cada acto nuestro supone un bien, entonces es obvio que uno nunca puede incurrir en el mal.

En este sentido, el suicidio es un acto de completa y absoluta libertad encaminada al bien. Me uno a las filas del pensamiento de Thomas Szasz (2002a) y doy razón de las pocas veces que damos lugar a la idea de reconocer el derecho a suicidarse. Sin duda, se puede asumir un acto personal y confrontante a la vez. La terminación voluntaria de la propia vida se da a partir de una forma de conducta y no como una enfermedad. Si esto es cierto, entonces esto tiene que llevarnos a pensar en el reconocimiento y aceptación del suicidio como un acto ejemplar y tal vez como modelo a seguir.

El suicidio supone la posibilidad de elección y dicha elección es, por definición, por voluntad propia. ¿Pero qué es eso de voluntad propia? Es cuando asumimos la responsabilidad de nuestros actos. Desde una visión coloquial pienso que el suicido es absoluta responsabilidad de quien lleva a cabo dicho acto en tanto ejercicio de aptitud y capacidad que lo posibilita para optar por esa opción de entre dos o más que se le presentan.

Por otro lado, cuando hablamos del suicidio lo relacionamos con una variedad de temáticas tales como felicidad, identidad, libertad y ética, principalmente. Sin embargo, se encuentra relacionado íntimamente con dos conceptos por encima de cualquier otro, siendo estos los pilares centrales al tratar el suicidio: la vida y la muerte. De hecho, estos dos conceptos, que a primera vista aparentan ser antagónicos, le imprimen un valor y sentido único al suicidio. El concepto de vida no se aleja de noción de muerte y viceversa.

\section{Vida, muerte y suicidio}

Empezaré por tratar el concepto de vida y su principal relación con el suicido. Lo más importante radica en la valoración e interpretación de la noción de la vida misma. El primer problema que se nos presenta es el de definir qué es la vida. La vida se ha entendido desde diferentes puntos de vista a través de la historia. Esto nos lleva al cuestionamiento que habríamos de hacer: ¿desde qué aproximación de conocimiento vamos a entender la vida? Desde la filosofía, por ejemplo, en el Fedón de Platón, Sócrates sostiene que todo verdadero filósofo debe vivir para morir ya que sólo en la muerte le permite alejarse totalmente del engaño del cuerpo y alcanzar la verdad. Así, uno de los objetivos principales del filósofo es alcanzar la verdad y sólo es posible con la muerte, siendo que la muerte no es garantía para llegar a la verdad. Lo importante para un filósofo es la vida, y la muerte sólo es beneficiosa si se ha vivido correctamente.

Por otro lado, si nos centramos en la noción científica de la biología, aún existen dificultades para definir lo que es la vida. Sin embargo, hay varias aproximaciones que permite delimitarla. Desde la fisiología, el experto en dicha rama nos podrá explicar la vida en sus propios términos, señalando que ésta refiere a aquellos organismos que están compuestos por materia orgánica (carbono, hidrógeno, oxígeno y nitrógeno) y son capaces de realizar funciones tales como comer, excretar, respirar, moverse, crecer, reproducirse y responder a estímulos externos. 
Existen tantas nociones de vida como el número de disciplinas que lo abordan: literatura, política, religión, economía, arte, etc. Con este panorama es obvio que no podríamos sostener que haya una definición "mejor" que otra. No obstante, parece que la noción científica es la dominante en nuestro pensamiento actual, por consiguiente, es la concepción que va a permear la naturaleza de los actos suicidas.

Un segundo cuestionamiento que debemos hacernos es el siguiente: ¿por qué deberíamos conservar la vida? Para la mayoría resultará una pregunta de respuesta obvia. Habremos algunos pocos más sensatos, que nos haremos el cuestionamiento y problematizaremos mediante la búsqueda de una respuesta más allá del sentido común.

Es claro que desde hace ya varios siglos hasta nuestros días existe la idea general de la vida como aquello que debe conservarse a toda costa. En este imaginario social, que es el sentido común, la vida es lo más preciado que uno tiene y, por ello, se debe preservar. Sin duda, como ya vimos, existen dos fuertes influencias que subyacen en esta idea: el cristianismo y la teoría de la evolución.

La religión cristiana, ante la inevitable muerte, nos prepara para cuando llegue ese momento. Nos ofrece una serie de reglas que se deben cumplir en este mundo terrenal para poder tener acceso al mundo divino y eterno (si es que existe tal mundo). Me parece que es preferible la honestidad de Sócrates, en voz de Platón, en cuanto al absurdo de temer a algo que no sabemos, que no conocemos, tal es el caso de la muerte. Sócrates, antes de suicidarse bebiendo la cicuta, expresa que no le teme a la muerte pues eso implica una pretensión de conocimiento de saber lo que hay después de ella, algo que no es posible.

De hecho, es posible que si nos encontráramos en condiciones de saber qué es la muerte perderíamos el sentido de la vida. La incertidumbre de la muerte es la marca de nuestra condición humana. Cuando la muerte llega a una persona, generalmente, hace que broten una cadena de emociones relacionadas con la tristeza y el dolor. Las instituciones sociales exigen el respeto total a la muerte por lo que significa y por las emociones y sentimientos que genera. Se vuelve un deber expresar dolor frente a la muerte.

Tal vez sea adecuado quedarnos con la frase de Camus (1995) que resume los aspectos de la vida y la muerte en un sentido:

Ahora puedo abordar la noción de suicidio. Se ha advertido ya qué solución es posible darle. En este punto se invierte el problema. Anteriormente se trataba de saber si la vida debía tener un sentido para vivirla. Ahora parece, por el contrario, que se la vivirá tanto mejor si no tiene sentido. Vivir una experiencia, un destino, es aceptarlo plenamente. Ahora bien, no se vivirá ese destino, sabiendo que es absurdo, si no se hace todo para mantener ante uno mismo ese absurdo puesto de manifiesto por la conciencia. (p. 74)

Si tuviéramos que dar algún argumento a favor de la vida, posiblemente, sería el siguiente: la finitud del hombre es una contradicción que permite llegar a la reflexión que ningún otro organismo puede hacerse, es decir, el hecho mismo de saber que somos seres que moriremos en algún momento, y que tenemos noción de ello, nos impulsa al conocimiento y cuestionamiento sobre el mundo. Moriremos, eso lo sabemos y si lo analizamos con cuidado podremos decir que es patético. 
Desde mi punto de vista, el asunto es simple y sencillo. Una vida por muy efímera e inocua que sea, no vale menos que otra. Comparto el pensamiento del empirista David Hume (2002) quien escribió lo siguiente acerca del valor de la vida humana:

Pero la vida de un hombre no es de mayor importancia para el universo que la de una ostra. Y si fuera de una importancia tan grande el orden de la naturaleza la ha sometido en realidad a la prudencia humana y nos ha reducido a ser mero requisito en cada incidente que le concierne. (p. 183)

Sin embargo, esto no implica que la vida carezca de propósito, todo lo contrario, en la medida en que se acerca la muerte de cada uno de nosotros el valor de la vida aumenta. Debemos de aprender a decir que "sí" a cada segundo, minuto y día de la vida. El mismo hecho de morir es lo que le impregna importancia a la vida. La muerte nos imprime algo particular y único sobre todas las demás cosas. Nuestra realidad humana es inevitablemente mortal e inacabada y justamente esa finitud nos convierte en seres únicos y especiales, pues cobra un valor infinito con cada acto de nuestra vida. Imaginemos por un momento que fuéramos eternos como los dioses. Si fuéramos inmortales, cada segundo de la eternidad no valdría absolutamente nada porque es algo que se va a repetir en el infinito.

Claro, aun sabiendo esto que menciono nadie de nosotros quiere morir. Generalmente, se piensa que es una incertidumbre total la llegada de la muerte. No sabemos cuándo se va a presentar. Pero, esto es falso, pues podemos elegir el día, la hora y el modo. Al igual que sucede con el concepto de la vida, hay múltiples formas de hablar de la muerte y resulta difícil englobar un concepto único.

A partir de la diversidad de concepciones de la muerte se han formulado teorías filosóficas, religiosas y científicas que proponen explicaciones a las preguntas de qué es, cómo es y por qué así ocurre la muerte. Sin embargo, ninguna ha sido contundente. De hecho, no podemos esperar alguna respuesta absoluta al respecto a pesar de que la muerte es parte de nosotros.

Es un hecho que, en nuestros días, referir a la muerte ha dejado de tener aquella característica transcendental que se postula como un puente que va más allá de la realidad material. Con el comienzo de la era moderna, el concepto de la muerte sucumbió bajo el paradigma científico que la explica como el fin de un ciclo natural. La muerte ha perdido su misticismo y han desaparecido los fantasmas que la rodeaban desde tiempos inmemoriales. Ahora, todo se reduce a algo más simple: después de la muerte no hay nada, sólo es el final inevitable de la vida.

No obstante, la explicación moderna parece no ser suficiente pues no va más allá de una descripción meramente temporal de los seres vivos. ¿Acaso entonces nunca tendremos una explicación definitiva de la muerte, aunque sea en un sólo nivel discursivo? La respuesta es un contundente no. La muerte por sí misma se encuentra fuera de todo conocimiento, principalmente por el inexistente medio para experimentarla, es imposible comprobarla o explorarla. La muerte es una experiencia que nadie jamás podrá conocer con exactitud y ello parece generar angustia en las personas. Por eso, el filósofo griego Epicuro pensaba que la muerte no es nada para nosotros, porque mientras vivimos, no existe la muerte, y cuando la muerte existe, ya no somos. Esto nos lleva a la paradoja de la imposibilidad de experimentar nuestra propia muerte. 
Independientemente de que podamos o no experimentar nuestra propia muerte, es cierto que se le ha temido a la muerte desde siempre. Pero, es claro que la mayor parte del tiempo no hemos existido, por lo tanto, no debería de preocuparnos dejar de existir después de la muerte. Como dijo alguna vez Schopenhauer (2013):

Puedo consolarme por el tiempo infinito tras mi muerte, en el que no existiré, con el tiempo infinito en el que yo no existía todavía, como un estado al que estoy acostumbrado y resulta verdaderamente confortable. Pues la infinitud posterior sin mí puede ser tan escasamente espantosa como la infinitud anterior sin mí, dado que ambas sólo se diferencian por la intromisión de un efímero lapso vital. (p. 451)

Se piensa que los suicidios son reflejo de en una sociedad "rota" o "quebrada", de individuos que actúan con desesperación en una sociedad en decadencia. Sin embargo, el suicidio no necesariamente es un indicador de un proceso de descomposición social. No sólo eso, se puede afirmar que en realidad se trata de una sociedad madura en tanto se comprende que es un acto de elección libre que siempre supone un bien. Considero que deberíamos repensar los modos de morir elegidos por uno mismo como un ejercicio intelectual.

Así pues, en un mundo donde todas las personas ofrecen respuestas y certezas absolutas de casi cualquier cosa a través de manuales, redes sociales del internet y diversos medios de comunicación, es importante entender que el suicidio no es un problema, por eso no tiene sentido buscar una solución o mistificarla porque es algo natural. Bienvenido sea el suicido, pues si la vida no tiene sentido y la muerte tampoco, el suicidio no tiene sentido. 


\section{Comentarios Finales}

Albert Camus escribió alguna vez que el suicidio no resuelve el absurdo de vivir y que el suicidio es sólo una interpretación de la vida, "Pero es malo detenerse, difícil contentarse con una sola manera de ver, privarse de la contradicción, la más sutil, quizá, de todas las formas espirituales. Lo que precede define solamente una manera de pensar” (Camus, 1995, p. 87). En este libro, he pretendido dar mi interpretación del suicidio mediante un panorama introductorio al tema con base en una propuesta psicológica para su estudio y aplicación del conocimiento. Además, he expresado algunas reflexiones personales que se vinculan con aquellas situaciones que cualquiera de nosotros se encuentra en la vida diaria y en las que puede ser útil el uso del control del suicidio. En este sentido, mi interpretación del suicidio debe cuestionarse de forma crítica, así como las múltiples interpretaciones existentes acerca del mundo y la realidad.

El análisis del suicidio que elaboré desde las teorías psicológicas y la investigación realizada desde hace varias décadas hasta la actualidad, la puedo resumir de la siguiente forma: son demasiados estudios los que se han realizado, acumulando abundante información con el propósito de entender las causas del suicidio con diversos hallazgos teóricos y empíricos. Sin embargo, aún sigue siendo para muchos especialistas poco esclarecedor el hecho de que una persona elija morir por propia mano. No sólo eso, a pesar de toda la información de estas investigaciones y de diversas fuentes, parecen no ser lo suficientemente confiables, pues existe un exceso de contradicciones al momento de explicar este fenómeno conductual. Es de sorprenderse que continuemos afirmando que la conducta suicida constituye un acontecimiento enigmático teniendo tantos modelos explicativos desde la psicología y otras disciplinas.

Me parece claro que todo esto es consecuencia de la poca claridad teórica y conceptual que vive la disciplina desde ya hace mucho tiempo. De ahí que se refleje la poca efectividad para predecir y prevenir los suicidios a nivel mundial. Y esto seguirá así si continuamos sosteniendo el supuesto del suicidio como una enfermedad mental. Simplemente, esto no tiene sustento, porque el dualismo mente-cuerpo es un error conceptual e histórico que no hemos podido superar en pleno siglo XXI. Me preocupa, al igual que muchos otros colegas, el desinterés que hay entre los profesionales por los análisis históricos y lógicos de los conceptos que usamos en psicología. Es una tarea obligada de clarificación conceptual y teórica para el trazo del camino correcto para plantearnos problemas significativos acerca del comportamiento suicida. 
Si bien, esta es una primera aproximación explícita al comportamiento suicida desde la psicología interconductual, no por ello significa que su contenido sea original dentro del área. Todo lo contrario, lo que he expresado no tiene nada de novedoso. Simplemente, ofrezco una posible lectura del suicidio desde una psicología que está en condiciones óptimas para el desarrollo de investigación básica, aplicada y tecnológica. Con base en este sistema psicológico interconductual (o en todo caso de un modelo teórico más acorde a los criterios de la ciencia) propongo que se dé mayor atención a la investigación de corte experimental y se ocupe de generar las condiciones para promover este comportamiento con fines de conocimientos y, posteriormente, con sus aplicaciones tecnológicas para la solución de este problema desde el ámbito de la salud.

Respecto a esto último que menciono, el desarrollo de tecnología, hago una apología por el control del suicido únicamente con fines científicos al alcance de todos. Seguramente, será una propuesta considerada por muchos como un disparate, con nulo apoyo desde muchos sectores de la salud y de diferentes esferas académicas. Sin embargo, es una propuesta alternativa que formulo desde terreno científico, justo es este el espacio perfecto para elaborar propuestas audaces en nuestros días. Debo aclarar que a partir del sistema psicológico interconductual se pueden derivar estrategias para la prevención del suicidio y no solamente el control del mismo como lo he sugerido. Hasta ahora, no disponemos de una tecnología interconductual que permita el control del suicidio con fines de generar conocimiento, por consiguiente, existe un campo amplio de investigación en esta área.

Si la tecnología psicológica es la aplicación de los conocimientos de la ciencia, entonces es importante contar con firmes fundamentos del modelo teórico que permitan derivar dicha tecnología. En consiguiente con esto, el uso del Análisis Contingencial para el control del suicidio depende en gran medida del conocimiento y dominio del modelo interconductual, es decir, de los compromisos epistemológicos y ontológicos de la postura teórica. El Análisis Contingencial es tan sólo una posible forma de proceder para el control del suicidio. No obstante, en tanto se trate de un sistema de intervención tecnológica, pueden elaborarse diferentes propuestas de aplicación similar, siempre y cuando estén fundamentadas bajo las mismas premisas y lógica causal. Debo resaltar el valor heurístico del modelo interconductual para el estudio y aplicación tecnológica en los fenómenos psicológicos, además de hacer explícito la necesaria aproximación interdisciplinaria y transdisciplinaria para el estudio del suicidio, pues el fenómeno es muy complejo e involucra distintas dimensiones (Morfin y Martín, 2015).

Para finalizar debo decir que, si el presente texto despierta algún interés en el lector por analizar o profundizar en el tema del suicidio en cualquiera de los aspectos que lo involucran, entonces el libro habrá cumplido con su cometido. Lo más importante es no dejar de reflexionar y continuar discutiendo el tema pues lejos está de agotarse. La mejor forma de hacer esto es tomar una posición al respecto, como lo he intentado hacer en este escrito. 


\section{REFERENCIAS}

Acevedo, J. (2015). Gritos silenciosos, el suicidio infantil. México: Trillas.

Acuña, L. (2010). El uso de la estadística en el análisis de la conducta: ¿cuándo usarla y cuándo no? Revista Mexicana de Análisis de la Conducta, 36(1), 133-145.

AFP (septiembre 5, 2014). Se suicidan 800 mil cada año; es un "drama" que se puede evitar: OMS. La Jornada, 44. Recuperado de http://www.jornada.unam.mx/2014/09/05/sociedad/044n1soc

Águila, A. (2011). Suicidio: la última decisión. México: Trillas.

Alcaraz, V.M., \& Gumá, E. (Comps.). (2001). Texto de neurociencias cognitivas. México: Manual Moderno.

Álvarez, M.A., \& Trápaga, M. (2008). Principios de neurociencias para psicólogos. Buenos Aires: Paidós.

Ardila, A., \& Rosselli, M. (2007). Neuropsicología clínica. México: Manual Moderno.

Aristóteles (1994). Metafísica. Madrid: Editorial Gredos.

Aristóteles (2010). Ética Nicomaquea. México: Editorial Porrúa.

Asch, S. (1980). Suicide and the hidden executioner. International Review of Psychoanalysis, 7, 51-60.

Asociación Mexicana de Internet (2017). 13 Estudio sobre los Hábitos de los Usuarios de Internet en México 2017.

Recuperado de https://www.asociaciondeinternet.mx/es/estudios

Beck, A. (1979). Cognitive therapy and the emotional disorders. New York: International Universities Press.

Beck, A.T., Kovacs M., \& Weissman A. (1979). Assessment of suicidal intention: The Scale for Suicide Ideation. Journal of Consulting and Clinical Psychology, 47(2), 343-352.

Beck, A.T., \& Lester, D. (1973). Components of depression in attempted suicides. Journal of Psychology, 5(2), 257-260.

Beatty, S.E., \& Hawkins, D.I. (1989). Subliminal stimulation: Some new data and interpretation. Journal of Advertising, $18,4-8$.

Bobes, J., Sáiz, P., García-Portilla, M., Bascarán, M., \& Bousoño, G. (2004). Comportamientos suicidas: prevención y tratamiento. Barcelona: Ars Médica.

Bobes, J., Sáiz, P., García-Portilla, M., \& Bousoño, G. (1996). Bases biológicas de las conductas suicidas y parasuicidas. Focus on Psychiatry, 3, 52-64. 
Bodelón, S. (1994-1995). El discurso antipagano de Octavio en la obra de Minucio Félix. Memorias de historia antigua, 15-16, 51-142. Recuperado de https://dialnet.unirioja.es/servlet/articulo? codigo=46129

Borges, G., Orozco, R., Benjet, C., \& Medina-Mora, M.E. (2010). Suicidio y conductas suicidas en México: retrospectiva y situación actual. Salud Pública de México, 52(4), 292-304.

Braunstein, N., Pasternac, M., Benedito, G., \& Saal, F. (2008). Psicología: ideología y ciencia. México: Siglo XXI.

Brown, R. (2001). El arte del suicidio. Madrid: Editorial Alianza.

Bruner, C. (2007). Las muchas aplicaciones de la única psicología. Revista Mexicana de Psicología, 24(1), 23-30.

Buck, J.N., \& Warren, W.L. (1995). Manual y guía de interpretación de la técnica de dibujo proyectivo H-T-P. México: Manual Moderno.

Bueno, R. (2011). Reflexiones acerca del objeto y metas de la psicología como una ciencia natural. Liberabit. Revista de Psicología, 17(1), 37-48.

Bunge, M. (1980). Epistemología. México: Siglo XXI.

Bunge, M. (1989). La ciencia, su método y su filosofía. Buenos Aires: Siglo Veinte.

Campanilla, G. (1985). Los psicofármacos antidepresivos y el suicidio. Psicopatología, 5(2), 121-127.

Camus, A. (1995). El mito de Sísifo. Madril: Alianza Editorial.

Camus, A. (2015). La Caída. Buenos Aires: Editorial Losada.

Carpio, C. (1994). Comportamiento animal y teoría de la conducta. En L. Hayes, E. Ribes y F. López (eds.), Psicología Interconductual: Contribuciones en honor a J. R. Kantor (pp. 45-68). México: EDUG.

Carpio, C., Silva, H., Pacheco-Lechón, L., Arroyo, R., Canales, C., Morales, G., \& Pacheco, V. (2008). Efectos de consecuencias positivas y negativas sobre la conducta altruista. Universitas Psychologica, 7(1), 97-107.

Casullo, M. (1999). Aplicaciones del MMPI-2 en los ámbitos clínico, forense y laboral. Buenos Aires: Paidós.

Chalmers, A. (1982). ¿Qué es esa cosa llamada ciencia? México: Siglo XXI.

Chávez, A.M., Macías, L.F., \& Luna, M.G. (2011). Notas mexicanas suicidas. Un análisis cualitativo. Pensamiento psicológico, 9(17), 33-42.

Chomsky, N. (1984). El proceso contra B.F. Skinner. En F. Matson (coord.), Conductismo y humanismo. ¿Enfoques antagónicos o complementarios? (pp.73-95). México: Trillas.

Clemente, M., \& González, A. (1996). Suicidio. Una alternativa social. Madrid: Biblioteca nueva.

Comte, A. (1965). Discurso sobre el espíritu positivo. Buenos Aires: Aguilar.

Darwin, C. (2011). El origen de las especies. México: Editorial Porrúa.

Descartes, R. (1994). El discurso del método. Tratado de las pasiones. Barcelona: RBA Editores.

Descartes, R. (2011). Meditaciones metafísicas. Madrid: Editorial Alianza.

Díaz-González, E., \& Carpio, C. (1996). Criterios para la aplicación del conocimiento psicológico. En J.J., Sánchez, C., Carpio y E., Díaz-González (Comp.), Aplicaciones del conocimiento psicológico (pp. 221-236). México: Facultad de Psicología/ENEP Iztacala/DGAPA/Sociedad Mexicana de Psicología.

Dumas, A. (2013). El conde de Montecristo. San José: Imprenta Nacional. Recuperado de https://www.imprentanacional. go.cr/editorialdigital/libros/literatura\%20universal/el_conde_de_montecristo_edincr.pdf

Durkheim, E. (2012). El suicidio. Estudio sociológico. Madrid: Akal. 
Eguiluz, L.L. (2010). ¿Qué podemos hacer para evitar el suicidio? México: Editorial Pax México.

Ellis, T.E. (1986). Toward a cognitive therapy for suicidal individuals. Professional Psychology, 17, 125-130.

Ellis, T.E. (2008). Cognición y suicidio. Teoría, investigación y terapia. México: Manual Moderno.

Engels, F. (1966). De la autoridad. En: K. Marx y F. Engels, Obras escogidas. Moscú: Editorial Progreso. Recuperado de https://pendientedemigracion.ucm.es/info/bas/es/marx-eng/oeme2.htm

Farberow, N., \& Schneidman, E. (1961). The cry for help. New York: McGraw-Hill.

Fereyabend, P. (1980). Tratado contra el método. México: Tecnos.

Fernández, H. (2017). Niño de 10 años se suicida en Coahuila. El Universal. Recuperado de http://www.eluniversal. com.mx/estados/nino-de-10-anos-se-suicida-en-coahuila

Ferri, E. (1934). Homicidio-suicidio. Madrid: Editorial Reus.

Firestone, R.W. (1988). Voice Therapy: A psychotherapeutic approach to self-destructive behavior. Santa Barbara, CA: Glendon Association.

Foucault, M. (1986). Historia de la locura en la época clásica. Volumen I y II. México: Fondo de Cultura Económica. Freeman, A., \& Reinecke, M. (1995). Terapia cognitiva aplicada a la conducta suicida. Bilbo: Desclée de Brouwer.

Freud, S. (1996a). Más allá del principio de placer. Obras completas, tomo XVIII. Buenos Aires: Amorrortu.

Freud, S. (1996b). Duelo y melancolía. Obras completas, tomo XIV. Buenos Aires: Amorrortu.

Futterman, S. (1961) Suicide: a psychoanalytical point of view. En N. Farberow y E. Schneidman (coord.), The cry for help. New York: McGraw-Hill.

Gómez, E. (julio 14, 2014). Suicidios de jóvenes desconciertan a habitantes de San Juan Evangelista. La Jornada. Recuperado de http://www.jornada.unam.mx/2014/07/14/estados/031n1est

González, R. (junio 210, 2016). Por falta de dinero, seis de cada 10 hogares no tienen Internet. La Jornada. Recuperado de http://www.jornada.unam.mx/2016/06/10/economia/018n1eco

Göppinger, H. (1975). Criminología. Madrid: Editorial Reus.

Gross, R. (2007). Psicología, la ciencia de la mente y la conducta. México: El Manual Moderno.

Hanson, N. (1985). Patrones de descubrimiento. Observación y explicación. Madrid: Alianza Universidad.

Hayes, L.J. (1994). Psicología interconductual: básica y aplicada. En L. Hayes, E. Ribes y F. López (eds.), Psicología Interconductual: Contribuciones en honor a J.R. Kantor (pp. 111-126). México: EDUG.

Higareda, D., \& Hernández, D. (septiembre 10, 2017). Desatención eleva suicidio en jóvenes. El Universal. Recuperado de http://www.eluniversal.com.mx/periodismo-de-datos/desatencion-eleva-suicidio-en-jovenes

Hume, D. (2002). Del suicidio. De la inmortalidad del alma. México: Océano de México.

Hume, D. (2005). Tratado de la naturaleza humana. México: Editorial Porrúa.

Ingenieros, J. (2000). El hombre mediocre. Argentina: elaleph.com. Recuperado de http://www.cecies.org/imagenes/ edicion_176.pdf

Instituto Nacional de Estadística, Geografía e Informática (INEGI). (2017). Estadísticas a propósito del día mundial para la prevención del suicidio. México: INEGI. Recuperado de http://www.inegi.org.mx/saladeprensa/ aproposito/2017/suicidios2017_Nal.pdf 
Jiménez, A., \& González, C. (2003). Veinticinco años de investigación sobre suicidio en la Dirección de Investigaciones Epidemiológicas y Psicosociales del Instituto Nacional de Psiquiatría Ramón de la Fuente. Salud Mental, diciembre, 35-46.

Kantor, J.R. (1924). Principles of Psychology. Ohio: The Principia Press.

Kantor, J.R. (1978). Psicología Interconductual. Un ejemplo de construcción científica sistemática. México: Trillas.

Kantor, J.R. (1990). La evolución científica de la psicología. México: Trillas.

Kelly, G.A. (1961). Theory in therapy in suicide: the personal construct point of view. En N. Farberow y E. Schneidman (coord.), The cry for help. New York: McGraw-Hill.

Kposowa, A., \& D’Auria, S. (2010). Association of temporal factors and suicides in the United States, 2000-2004. Social Psychiatry Psychiatric Epidemiology, 45(4), 433-445.

Kuhn, T.S. (1971). La estructura de las revoluciones científicas. México: Fondo de Cultura Económica.

Kuhn, T.S. (1982). Objetividad, juicios de valor y elección de una teoría. En T.S. Kuhn (ed.), La tensión esencial: Estudios selectos sobre la tradición y el cambio en el ámbito de la ciencia (pp. 344-364). México: Fondo de Cultura Económica.

Lafargue, P. (s.f.). Recuerdos de Marx. En VV.AA., Cómo era Carlos Marx según quienes lo conocieron. Recuperado de https://www.marxists.org/espanol/m-e/bio/como.era.carlos.marx.pdf

Lezak, M.D., Howieson, D.B., \& Loring, D.W. (2004). Neuropsychological assessment. New York: Oxford University Press.

Linehan, M.M. (1993). Cognitive-behavioral treatment of borderline personality disorder. New York: Guilford Press.

Locke, J. (2005). Ensayo sobre el entendimiento humano. México: Editorial Porrúa.

López, E., \& Costa, M. (2014). Los problemas psicológicos no son enfermedades: Una crítica radical de la psicopatología. Madrid: Pirámide.

López, D. (1998). Evaluación y tratamiento de la conducta suicida. En: Psicología en México a fines del siglo XX. Tomo I (pp. 9-20). México: UNAM.

López, M., \& Tarasco, M. (2008). El acto humano: libertad y determinismo. Revista de la Asociación Psiquiátrica Mexicana, 24(1), 5-16.

López, S. (1997). Zen, acupuntura y psicología. México: Plaza y Valdés.

López, S. (2006). Órganos, emociones y vida cotidiana. México: Los Reyes.

Maquiavelo, N. (1998). El Príncipe. México: Editorial Losada.

Marchiori, H. (2000). El suicidio: enfoque criminológico. México: Editorial Porrúa.

Martín del Campo, A., González, C., \& Bustamante, J. (2013). El suicidio en adolescentes. Revista Médica del Hospital General de México, 76(4), 200-209.

Matarazzo, J.D. (1987). There is only one psychology, no specialties but many applications. American Psychologist, 42, 893-903.

Maya, N. (septiembre 10, 2014). El suicidio, problema grave que va al alza. El Universal. Recuperado de http://archivo. eluniversal.com.mx/nacion-mexico/2014/impreso/el-suicidio--218534.html 
Mawson, A., \& Jacobs, K. (1978). Corn consumption, tryptophan and cross-national homicide rates. Journal of Orthomolecular Psychiatry, 7, 227-230.

Maximus, M. (2002). La contingencia como concepto clave en el conductismo tradicional y el interconductismo. Integración. Educación y Desarrollo psicológico, 14(17), 100-104.

Méndez, E. (enero 17, 2014). Aumenta con rapidez el suicidio entre adolescentes y jóvenes en México: SSA. La Jornada, 37.

Middendorff, W. (1978). La criminalidad violenta de nuestra época. Madrid: Editorial Espasa-Calpe.

Miles, C.P. (1977). Condition predisposing to suicide: A review. The Journal of Nervous and Mental Disease, 164, 231 246.

Mondragón, L., Borges, G., \& Gutiérrez, R. (2001). La medición de la conducta suicida en México: estimaciones y procedimientos. Salud Mental, 24(6), 4-14.

Montesquieu, C-L. (2002). Del espíritu de las leyes. Tomo I. Madrid: Ediciones Istmo.

Morfin, T., \& Martín, A. (2015). Fenómeno suicida: un acercamiento transdisciplinar. México: Manual Moderno.

Morón, P. (1977). El suicidio. Buenos Aires: Editorial Ábaco.

Morris, E.K., Todd, J.T., \& Midgley, B.D. (1993). The prediction and control of behavior: Watson, Skinner, and beyond. Revista Mexicana de Análisis de la Conducta, 19, 103-131.

Olivares, A. (enero 3, 2013). Suicidio, tercera causa de muerte entre adolescentes mexicanos. La Jornada, 33. Recuperado de http://www.jornada.unam.mx/2013/01/03/sociedad/033n1soc

Organización Mundial de la Salud (2018). Suicidio. Recuperado de http://www.who.int/topics/suicide/es/

Ortega, M., \& Patrón, F. (en preparación). Análisis del comportamiento sustitutivo: el caso de las interacciones escritoras.

Pacheco-Lechón, L., \& Carpio, C. (2014). Mediación lingüística en las interacciones sociales: el caso de las instrucciones y los acuerdos verbales. Revista Electrónica de Psicología Iztacala, 12(7), 695-714.

Pacheco, V., \& Carpio, C. (2011). Observación y métricas en el análisis del comportamiento humano. México: UNAM. Pérez, R. (1990). ¿Existe el método científico? México: Fondo de Cultura Económica.

Pérez, O. (2007). Caracterización Psiquiátrica y Social del Intento Suicida Atendido en una Clínica Infantil, 20032005. Revista de Salud Pública, 9(2), 230-240.

Platón (1979). Diálogos. México: Editorial Porrúa.

Platón (1999). La Leyes. En Diálogos, vol. IX. Madrid: Gredos.

Plutchik, R. (2001). The nature of emotions. American Scientist, 89, 343-350.

Popper, K.R. (1983). Conjeturas y refutaciones. Barcelona: Paidós.

Porras, N.R. (2011). Del pluralismo al eclecticismo en la psicología de hoy: una reflexión epistemológica. Tesis Psicológica, 6, 151-172.

Portuondo, J. (2012). La figura humana: test proyectivo de Karen Machover. México: Siglo XXI.

Quintanar, F. (2008). Comportamiento suicida. Perfil psicológico y posibilidades de tratamiento. México: Editorial Pax. Rains, G.D. (2004). Principios de neuropsicología humana. México: McGraw-Hill.

Real Academia Española (RAE). (2017). Diccionario de la lengua española. Recuperado de http://www.rae.es/ Ribes, E. (1982). El conductismo: reflexiones críticas. Barcelona: Fontanella. 
Ribes, E. (1989). La psicología: algunas reflexiones sobre sobre su qué, su cómo, su por qué y su para qué. En J. Urbina (coord.), El psicólogo: formación, ejercicio profesional y prospectiva (pp. 847-860). México: UNAM.

Ribes, E. (1990). Psicología general. México: Trillas.

Ribes, E. (1998). Teoría de la conducta: logros, avances y tareas pendientes. Acta Comportamentalia, 6, 127-147.

Ribes, E. (2000). La psicología y la definición de sus objetos de conocimientos. Revista Mexicana de Análisis de la Conducta, 26, 365-382.

Ribes, E. (2008). Psicología y salud: Un análisis conceptual. México: Trillas.

Ribes, E. (2009). Reflexiones sobre la aplicación del conocimiento psicológico; ¿qué aplicar o cómo aplicar? Revista Mexicana de Análisis de la Conducta, 35, 3-17.

Ribes, E. (2013). Una reflexión sobre los modos generales de conocer los objetos de conocimiento de las diversas ciencias empíricas, incluidas la psicología. Revista Mexicana de Análisis de la Conducta, 30, 89-95.

Ribes, E. y López, F. (1985). Teoría de la conducta: Un análisis de campo y paramétrico. México: Trillas.

Ribes, E., Díaz-González, E., Rodríguez, M.L., \& Landa, D. (1986). El Análisis Contingencial: una alternativa a las aproximaciones terapéuticas del comportamiento. Cuadernos de Psicología, 8, 27-52.

Rivera, M.M., \& Herrera L. (2002). Perfil psicológico de personas con intento suicida. México: Instituto Politécnico Nacional.

Roca, J. (2006). Psicología: Una introducción teórica. Girona: EAP-Documenta Universitaria.

Rodríguez, A. (2001). Autopsia psicológica: una herramienta útil para el peritazgo psicológico. Recuperado de www. psicologiajuridica.org

Rodríguez, M.L. (1998). La regulación de la conducta moral: Una investigación preliminar. Enseñanza e Investigación en Psicología, 13(3), 85-115.

Rodríguez, M.L. (2002). Análisis Contingencial. México: UNAM.

Rodríguez, M.L. (2010). Mediación de relaciones de pareja. Un caso clínico desde el análisis contingencial. Revista Electrónica de Psicología de Iztacala, 13(3) 1-19.

Rodríguez, M.L., \& Landa, P. (1993). Validación del análisis contingencial como metodología de cambio conductual. Salud y Sociedad, 2(1) 27-36.

Rodríguez, M.L., Díaz-González y Anaya, E. (1999). El Análisis Contingencial y su Aplicación en un Problema Psicológico. Revista Electrónica de Psicología de Iztacala, 2(2).

Rodríguez, M.L., Ángeles, B., \& Coello, Y. (2003). Los padres como modelos de comportamiento social: un estudio de caso a través del análisis contingencial. Revista Electrónica de Psicología Iztacala, 6(1).

Ryle, G. (2002). El concepto de lo mental. Buenos Aires: Paidós.

Sacks, O. (2002). El hombre que confundió a su mujer con un sombrero. España: Editorial Anagrama.

San Agustín de Hipona (1988). La ciudad de Dios. Obras completas, vols. XVI-XVII, Madrid: Biblioteca de Autores Cristianos.

Sanmartín, J. (2002). La mente de los violentos. Barcelona: Editorial Ariel.

Santo Tomás de Aquino (1995). Suma de Teológica, III, Parte II-II (a). Madrid: Biblioteca de Autores Cristianos. Santoyo, C. , \& López, F. (1990). Análisis experimental del intercambio social. México: Trillas. 
Sartré, J.P. (1966). El ser y la nada. Buenos Aires: Editorial Losada.

Schneidman, E. (1968). Suicidal phenomena: Their definition and classification. En International Encyclopedia of the Social Sciences. New York: Macmillan.

Schneidman, E., Faberow, N., \& Litman, R. (1970). The psychology of suicide. New York. Science House.

Schopenhauer, A. (2013). El mundo como voluntad y representación. México: Editorial Porrúa.

Séneca, L.A. (1943). Cartas a Lucilio. Madrid: Editorial Aguilar.

Serrano, V. (2016). Fraudebook. Lo que la red social hace con nuestras vidas. Madrid: Plaza y Valdés.

Sidman, M. (1989). Coercion and its fallout. Boston, MA: Authors Cooperative.

Silva, A. (2003). Criminología y conducta antisocial. México: Editorial Pax.

Skinner, B.F. (1971). Ciencia y conducta humana. Barcelona: Editorial Fontanella.

Skinner, B.F. (1975). Sobre el conductismo. Barcelona: Editorial Fontanella.

Skinner, B.F. (1979). Contingencias de reforzamiento: Un análisis teórico. México: Trillas.

Smith, N.W. (2016). The Interbehavioral Alternative to Free Will and Determinism Constructs. Conductual, 4(2), 91-101.

Stengel, E. (1965). Psicología del suicidio y los intentos del suicidio. Buenos Aires: Editorial Hormé.

Szasz, T.S. (1989). El mito de la enfermedad mental. Buenos Aires: Amorrortu editores.

Szasz, T.S. (2001). Ideología y enfermedad mental. Buenos Aires: Amorrortu editores.

Szasz, T.S. (2002a). Libertad fatal: ética y política del suicidio. Barcelona: Paidós.

Szasz, T.S. (2002b). Esquizofrenia: el símbolo sagrado de la psiquiatría. México: Ediciones Coyoacán.

Téllez, M. (septiembre 9, 2014). INEGI revela estadísticas de suicidio. El Universal. Recuperado de http://archivo. eluniversal.com.mx/periodismo-datos/2014/inegi-revela-estadisticas-de-suicidio-94155.html

Tomasini, A. (2004). Libertad de la voluntad y acción involuntaria. Acta Comportamentalia, 12, 75-96.

Thompson, R. (1973). Fundamentos de psicología fisiológica. México: Trillas.

Turbayne, C. (1974). El mito de la metáfora. México: Fondo de Cultura Económica.

United Nations (1996). Prevention of suicide. Guidelines for the formulation and implementation of national strategies.

New York: United Nations Publications.

Varela, J. (2009). Conceptos básicos de interconductismo. México: Universidad de Guadalajara.

Vygotski, L. (1988). Pensamiento y lenguaje. México: Quinto sol.

Vygotski, L. (1979). El desarrollo de los procesos psicológicos superiores. Barcelona: Crítica.

Watson, J.B. (1916). The place of the conditioned reflex in psychology. Psychological Review, 23, 89-116.

Wittgenstein, L. (1997). Investigaciones filosóficas. Oxford: Brasil Blackwell. (Original en inglés, 1956)

World Internet Proyect (2013). Estudio 2013 de hábitos y percepciones de los mexicanos sobre Internet y diversas tecnologías asociadas. Recuperado de http://www.wip.mx 


\section{COMPORTAMIENTO SUICIDA}

Reflexiones críticas para su estudio desde un sistema psicológico

ISBN 978-607-97784-8-4

DOI 10.29410/QTP.18.05

Esta obra se terminó de producir en mayo de 2018.

Su edición y diseño estuvo a cargo de:

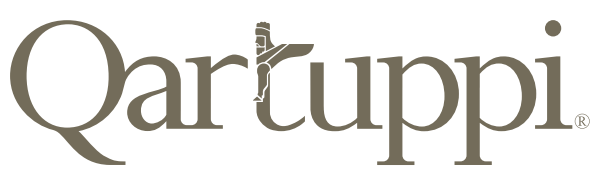

Qartuppi, S. de R.L. de C.V.

http://www.qartuppi.com 
(c) $($ i) (8)

Esta obra está bajo una Licencia Creative Commons Atribución-NoComercial 4.0 Internacional.

https://creativecommons.org/licenses/by-nc/4.0/deed.es 


\section{COMPORTAMIENTO SUICIDA}

Reflexiones críticas para su estudio desde un sistema psicológico tiene como propósito la reflexión y discusión por parte del lector a partir de la Piscología, ciencia considerada como uno de los pilares centrales para explicar esta forma de comportamiento desde un nivel de análisis específico de la realidad. El tema del suicidio ha sido, es y será un tópico del que nunca tendremos respuestas absolutas ya que no existen las preguntas finales. El suicidio es uno de esos temas de la condición humana que son eternos y no le pertenecen a alguna disciplina en particular.

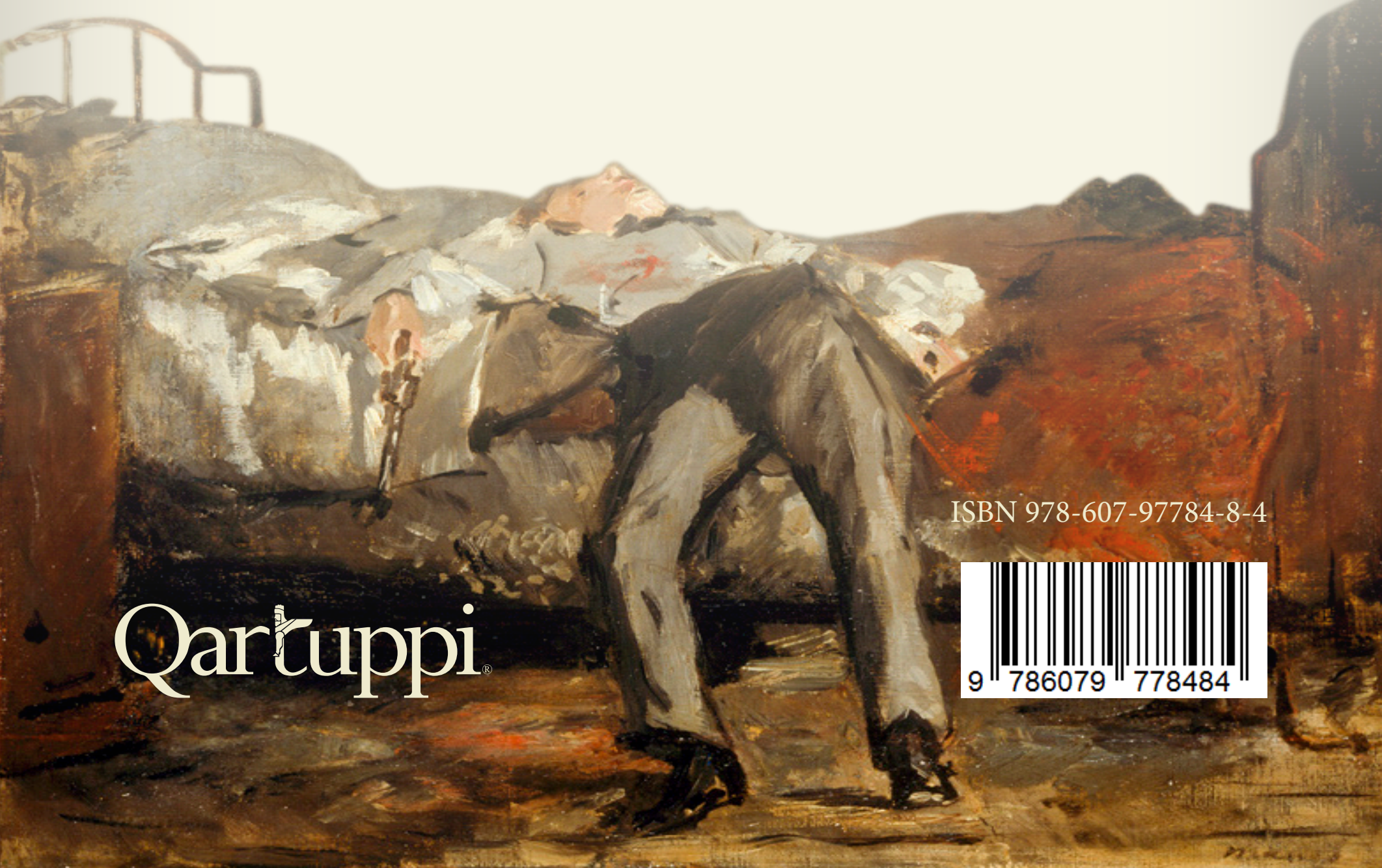

